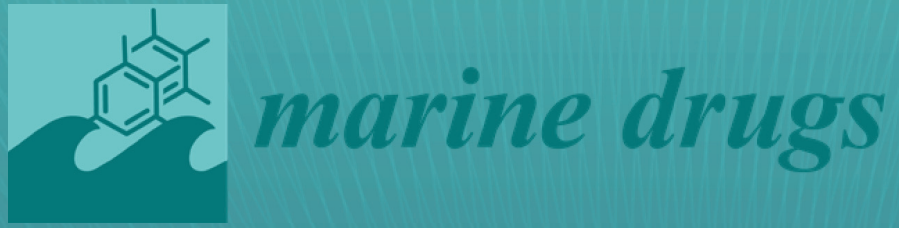

\title{
Bioactive Marine
}

\section{Heterocyclic \\ Compounds}

\section{Edited by}

Yoshihide Usami

Printed Edition of the Special Issue Published in Marine Drugs 


\section{Bioactive Marine Heterocyclic Compounds}





\section{Bioactive Marine Heterocyclic Compounds}

Editor

Yoshihide Usami 
Editor

Yoshihide Usami

Osaka University of

Pharmaceutical Sciences

Japan

Editorial Office

MDPI

St. Alban-Anlage 66

4052 Basel, Switzerland

This is a reprint of articles from the Special Issue published online in the open access journal Marine Drugs (ISSN 1660-3397) (available at: https://www.mdpi.com/journal/marinedrugs/ special_issues/Bioactive_Marine_Heterocyclic_Compounds).

For citation purposes, cite each article independently as indicated on the article page online and as indicated below:

LastName, A.A.; LastName, B.B.; LastName, C.C. Article Title. Journal Name Year, Volume Number, Page Range.

ISBN 978-3-0365-2752-9 (Hbk)

ISBN 978-3-0365-2753-6 (PDF)

(C) 2021 by the authors. Articles in this book are Open Access and distributed under the Creative Commons Attribution (CC BY) license, which allows users to download, copy and build upon published articles, as long as the author and publisher are properly credited, which ensures maximum dissemination and a wider impact of our publications.

The book as a whole is distributed by MDPI under the terms and conditions of the Creative Commons license CC BY-NC-ND. 


\section{Contents}

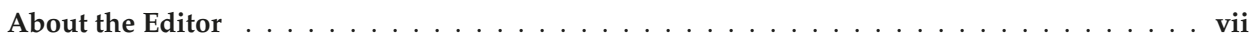

Preface to "Bioactive Marine Heterocyclic Compounds" . . . . . . . . . . . ix

Sanghoon Lee, Naonobu Tanaka, Sakura Takahashi, Daisuke Tsuji, Sang-Yong Kim, Mareshige Kojoma, Kohji Itoh, Jun'ichi Kobayashi and Yoshiki Kashiwada

Agesasines A and B, Bromopyrrole Alkaloids from Marine Sponges Agelas spp.

Reprinted from: Mar. Drugs 2020, 18, 455, doi:10.3390/md18090455 . . . . . . . . . . . . . . .

Atsushi Nakayama, Hideo Sato, Tenta Nakamura, Mai Hamada, Shuji Nagano,

Shuhei Kameyama, Yui Furue, Naoki Hayashi, Go Kamoshida, Sangita Karanjit,

Masataka Oda and Kosuke Namba

Synthesis and Antimicrobial Evaluation of Side-Chain Derivatives based on Eurotiumide A

Reprinted from: Mar. Drugs 2020, 18, 92, doi:10.3390/md18020092 . . . . . . . . . . . . . . . . .

Géraldine Le Goff, Philippe Lopes, Guillaume Arcile, Pinelopi Vlachou, Elsa Van Elslande, Pascal Retailleau, Jean-François Gallard, Michal Weis, Yehuda Benayahu, Nikolas Fokialakis and Jamal Ouazzani

Impact of the Cultivation Technique on the Production of Secondary Metabolites by Chrysosporium lobatum TM-237-S5, Isolated from the Sponge Acanthella cavernosa

Reprinted from: Mar. Drugs 2019, 17, 678, doi:10.3390/md17120678 . . . . . . . . . . . . . .

Chunyan Zhang, Wenjuan Ding, Xiangjing Qin and Jianhua Ju

Genome Sequencing of Streptomyces olivaceus SCSIO T05 and Activated Production of Lobophorin CR4 via Metabolic Engineering and Genome Mining

Reprinted from: Mar. Drugs 2019, 17, 593, doi:10.3390/md17100593 . . . . . . . . . . . . . . .

Fan-Zhong Zhang, Xiao-Ming Li, Xin Li, Sui-Qun Yang, Ling-Hong Meng and Bin-Gui Wang Polyketides from the Mangrove-Derived Endophytic Fungus Cladosporium cladosporioides Reprinted from: Mar. Drugs 2019, 17, 296, doi:10.3390/md17050296 . . . . . . . . . . . . . . . 53

Takeshi Yamada, Asumi Tanaka, Tatsuo Nehira, Takumi Nishii and Takashi Kikuchi Altercrasins A-E, Decalin Derivatives, from a Sea-Urchin-Derived Alternaria sp.: Isolation and Structural Analysis Including Stereochemistry

Reprinted from: Mar. Drugs 2019, 17, 218, doi:10.3390/md17040218 . . . . . . . . . . . . . .

Rajiv Dahiya, Sunita Dahiya, Neeraj Kumar Fuloria, Suresh Kumar, Rita Mourya, Suresh V. Chennupati, Satish Jankie, Hemendra Gautam, Sunil Singh, Sanjay Kumar Karan, Sandeep Maharaj, Shivkanya Fuloria, Jyoti Shrivastava, Alka Agarwal, Shamjeet Singh, Awadh Kishor, Gunjan Jadon and Ajay Sharma Natural Bioactive Thiazole-Based Peptides from Marine Resources: Structural and Pharmacological Aspects

Reprinted from: Mar. Drugs 2020, 18, 329, doi:10.3390/md18060329 . . . . . . . . . . . . . 77 



\section{About the Editor}

Yoshihide Usami (PhD) is a Professor of the Department of Pharmaceutical Organic Chemistry at Osaka University of Pharmaceutical Sciences (OUPS, renamed as Osaka Medical and Pharmaceutical University in April 2021). His research team focuses on natural product chemistry, synthetic organic chemistry, and medicinal chemistry. He received his PhD from Kyoto University under the supervision of Professor Kaoru Fuji in 1989 and worked on the isolation of bioactive marine natural products in OUPS under Professor Atsushi Numata from 1989 to 2004. During the period 2005-2006, he was invited as a Visiting Assistant Professor at the University of North Carolina at Chapel Hill under Professor K. H. Lee. After returning to OUPS, he became an Associate Professor to Professor Shinya Harusawa (Pharmaceutical Organic Chemistry) and was promoted to Full Professor in 2019. He received the Kansai-Branch Award of Society of Synthetic Organic Chemistry, Japan, in 2015 and served as an Editorial Board member of Chem. Pharm. Bull., Biol. Pharm. Bull., and Yakugaku Zasshi during 2016-2019. He has been an Editorial Board member of Marine Drugs from 2008 to date. Prior to this Special Issue, he has edited two other Special Issues of Marine Drugs in 2014 and 2016. 



\section{Preface to "Bioactive Marine Heterocyclic Compounds"}

Nowadays, the importance of marine-derived heterocyclic natural products is progressively increasing for new drug discovery. This Special Issue of Marine Drugs, entitled "Bioactive Marine Heterocyclic Compounds", aimed to collect excellent original research articles and reviews focused on the isolation of new heterocyclic marine natural products, total synthesis, synthetic modification, or on finding important bioactivities of known heterocyclic marine natural products. As a result, five original papers on isolation and one synthetic study of metabolites from marine-derived bioorganisms or a marine sponge, along with one review paper on thiazole-based peptides, were published. I am proud to show these most recent works of outstanding scientists in this field and hope this Special issue will affect new drug developments or innovation in the future.

Yoshihide Usami

Editor 

Article

\title{
Agesasines A and B, Bromopyrrole Alkaloids from Marine Sponges Agelas spp.
}

\author{
Sanghoon Lee ${ }^{1,2}$, Naonobu Tanaka ${ }^{1, *}$, Sakura Takahashi ${ }^{1}$, Daisuke Tsuji ${ }^{1}$, Sang-Yong Kim ${ }^{3}$, \\ Mareshige Kojoma ${ }^{3}$, Kohji Itoh ${ }^{1}$, Jun'ichi Kobayashi ${ }^{4}$ and Yoshiki Kashiwada ${ }^{1, *}$ \\ 1 Graduate School of Pharmaceutical Sciences, Tokushima University, Tokushima 770-8505, Japan; \\ sanghoon_lee@sfu.ca (S.L.); c402031011@tokushima-u.ac.jp (S.T.); dtsuji@tokushima-u.ac.jp (D.T.); \\ kitoh@tokushima-u.ac.jp (K.I.) \\ 2 Department of Chemistry, Simon Fraser University, Burnaby, BC V5A 1S6, Canada \\ 3 Faculty of Pharmaceutical Sciences, Health Sciences University of Hokkaido, Tobetsu 061-0293, Japan; \\ kim@hoku-iryo-u.ac.jp (S.-Y.K.); kojoma@hoku-iryo-u.ac.jp (M.K.) \\ 4 Graduate School of Pharmaceutical Sciences, Hokkaido University, Sapporo 060-0812, Japan; \\ jkobay@pharm.hokudai.ac.jp \\ * Correspondence: ntanak@tokushima-u.ac.jp (N.T.); kasiwada@tokushima-u.ac.jp (Y.K.)
}

Received: 29 June 2020; Accepted: 27 August 2020; Published: 30 August 2020

\begin{abstract}
Exploration for specialized metabolites of Okinawan marine sponges Agelas spp. resulted in the isolation of five new bromopyrrole alkaloids, agesasines A (1) and B (2), 9-hydroxydihydrodispacamide (3), 9-hydroxydihydrooroidin (4), and 9E-keramadine (5). Their structures were elucidated on the basis of spectroscopic analyses. Agesasines A (1) and B (2) were assigned as rare bromopyrrole alkaloids lacking an aminoimidazole moiety, while 3-5 were elucidated to be linear bromopyrrole alkaloids with either aminoimidazolone, aminoimidazole, or $\mathrm{N}$-methylated aminoimidazole moieties.
\end{abstract}

Keywords: agesasines; bromopyrrole alkaloid; marine sponge; Agelas

\section{Introduction}

A number of structurally unique bioactive specialized metabolites have been isolated from marine sources including sponges, algae, cnidarians, and marine microorganisms, etc. [1]. To date, more than 8000 species of marine sponges (phylum Porifera) have been found under the sea throughout tropical, temperate, and polar area [2]. Marine sponges utilize some of their specialized metabolites as chemical defenses against predator attacks, microbial infections, biofouling, and overgrowth of other sessile organisms [3,4]. On the other hand, natural products isolated from marine sponges are recognized as an attractive source of leads for therapeutic agents due to a diversity of their chemical structures and biological activities.

Marine sponges belonging to the genus Agelas are known to be a rich source of bromopyrrole alkaloids and diterpene alkaloids that have been used as a taxonomically characteristic maker [5]. In our search for structurally unique marine natural products [6-8], we have recently reported the isolation of diterpene alkaloids from the extracts of a marine sponge Agelas spp. [9]. As part of this research project, we have investigated another specimen of Agelas marine sponges, which resulted in the isolation of five new bromopyrrole alkaloids (1-5). Among others, agesasines A (1) and B (2) are rare bromopyrrole alkaloids lacking an aminoimidazole moiety, from the point of view that typical bromopyrrole alkaloids consist of a brominated pyrrolecarboxamide moiety and an aminoimidazole moiety linked through a $C_{3}$ unit. Herein, we describe the isolation and structure elucidation of 1-5. 


\section{Results and Discussion}

\subsection{Isolation of 1-5 from Marine Sponges Agelas spp.}

Two specimens of the marine sponge Agelas spp. (SS-516 and SS-1302) were separately extracted with $\mathrm{MeOH}$ to give extracts, each of which was partitioned between $n$-hexane and $90 \% \mathrm{MeOH}$ aq. Repeated chromatographic separations of the $90 \% \mathrm{MeOH}$ aq.-soluble materials from SS-516 gave two new bromopyrrole alkaloids, agesasines A (1, $2.5 \mathrm{mg}$ ) and B (2, $2.2 \mathrm{mg}$ ) (Figure 1) together with two known bromopyrrole alkaloids, tauroacidin A [10] and taurodispacamide A [11]. In contrast, the $90 \% \mathrm{MeOH}$ aq.-soluble materials of SS-1302 were further partitioned with $n$ - $\mathrm{BuOH}$ and water. The $n$-BuOH-soluble materials were separated by column chromatographies to give three new bromopyrrole alkaloids, 9-hydroxydihydrodispacamide (3, $5.0 \mathrm{mg})$, 9-hydroxydihydrooroidin $(4,2.1 \mathrm{mg})$, and $9 E$-keramadine $(5,3.1 \mathrm{mg})$ (Figure 1), together with four known alkaloids, oroidin [12,13], keramadine [14], 2-bromo-9,10-dihydrokeramadine [15], and nagelamide L [16].<smiles>COC(=O)[C@H](O)CNC(=O)c1cc(Br)c(Br)[nH]1</smiles><smiles>COC(=O)C[C@H](O)CNC(=O)c1cc(Br)c(Br)[nH]1</smiles><smiles></smiles><smiles></smiles><smiles></smiles>

Figure 1. Structures of agesasines A (1) and B (2), 9-hydroxydihydrodispacamide (3), 9-hydroxydihydrooroidin (4), and 9E-keramadine (5).

\subsection{Structure Elucidation of $\mathbf{1 - 5}$}

Agesasine A (1) displayed ion peaks at $m / z$ 391, 393, and 395 (1:2:1), suggesting the presence of two bromine atoms in 1 . The molecular formula of $1, \mathrm{C}_{9} \mathrm{H}_{10} \mathrm{~N}_{2} \mathrm{O}_{4} \mathrm{Br}_{2}$, was determined by the high-resolution electrospray ionization mass spectrometry (HRESIMS) $\left(\mathrm{m} / \mathrm{z} 390.89045[\mathrm{M}+\mathrm{Na}]^{+}\right.$, $\Delta-0.05 \mathrm{mmu}$ ). The ${ }^{1} \mathrm{H}$ and ${ }^{13} \mathrm{C}$ NMR spectra (Table 1) displayed the signals of one $\mathrm{sp}^{3}$ methine, one $\mathrm{sp}^{3}$ methylene, one methoxy group, and one carboxy carbon as well as resonances assignable to a 2,3-dibromopyrrole carboxamide moiety (N-1 N-7). Analysis of the ${ }^{1} \mathrm{H}-{ }^{1} \mathrm{H}$ correlation spectroscopy (COSY) spectrum revealed the connectivities from 7-NH to 9-OH (Figure 2), while heteronuclear multiple bond coherence (HMBC) correlations for methoxy protons and $\mathrm{H}_{2}-8$ with $\mathrm{C}-10$ suggested the presence of a methoxy carbonyl group at C-9. Thus, the planar structure of agesasine A (1) was elucidated as shown in Figure 2. Agesasine B (2) showed an ion peak at $\mathrm{m} / \mathrm{z} 380.9088\left(\left[\mathrm{M}-\mathrm{H}^{-}\right.\right.$, $\Delta+0.2 \mathrm{mmu}$ ), corresponding to the molecular formula of $\mathrm{C}_{10} \mathrm{H}_{12} \mathrm{~N}_{2} \mathrm{O}_{4} \mathrm{Br}_{2}$. The 1D NMR spectra of 2 (Table 1 ) were closely correlated to those of $\mathbf{1}$, except for the presence of an additional $\mathrm{sp}^{3}$ methylene signal $\left(\mathrm{CH}_{2}-10\right)$ in 2 . The methylene protons $\left(\mathrm{H}_{2}-10\right)$ showed a ${ }^{1} \mathrm{H}-{ }^{1} \mathrm{H}$ COSY cross-peak with $\mathrm{H}-9$ and an HMBC correlation with a methoxy carbonyl carbon (C-11), suggesting the planar structure of 2 as shown in Figure 2. 
Table 1. One-dimensional (1D) NMR data for agesasines A (1) and B (2) in DMSO- $d_{6}$.

\begin{tabular}{ccccc}
\hline \multirow{2}{*}{ Position } & \multicolumn{3}{c}{$\mathbf{1}$} & $\mathbf{2}$ \\
\cline { 2 - 5 } & ${ }^{\mathbf{1 3}} \mathbf{C}$ & ${ }^{\mathbf{1}} \mathbf{H}(\boldsymbol{J}$ in Hz) & ${ }^{\mathbf{1 3}} \mathbf{C}$ & ${ }^{\mathbf{1}} \mathbf{H}(\boldsymbol{J}$ in Hz) \\
\hline 1 & - & 12.67 (brs) & - & $12.65(\mathrm{brs})$ \\
2 & 104.8 & - & 104.7 & - \\
3 & 98.0 & - & 98.0 & - \\
4 & 113.1 & $6.93(\mathrm{brs})$ & 113.0 & $6.93(\mathrm{~d}, 2,7)$ \\
5 & 128.1 & - & 128.3 & - \\
6 & 159.3 & - & 159.3 & - \\
7 & - & $8.20(\mathrm{t}, 5.8)$ & - & $8.12(\mathrm{t}, 5.5)$ \\
8 & 42.7 & $3.46,3.36($ each $1 \mathrm{H}, \mathrm{m})$ & 44.9 & $3.20(2 \mathrm{H}, \mathrm{m})$ \\
9 & 69.3 & $4.17(\mathrm{q}, 6.1)$ & 66.6 & $3.99(\mathrm{~m})$ \\
10 & 173.1 & - & 40.6 & $2.49(\mathrm{~m}), 2.27(\mathrm{dd}, 15.2,8.8)$ \\
11 & - & - & 171.8 & - \\
$9-\mathrm{OH}$ & - & $5.71(\mathrm{~d}, 5.9)$ & - & nd \\
OMe & 51.8 & $3.61(3 \mathrm{H}, \mathrm{brs})$ & 51.4 & $3.56(3 \mathrm{H}, \mathrm{brs})$ \\
\hline
\end{tabular}

nd: Not detected.
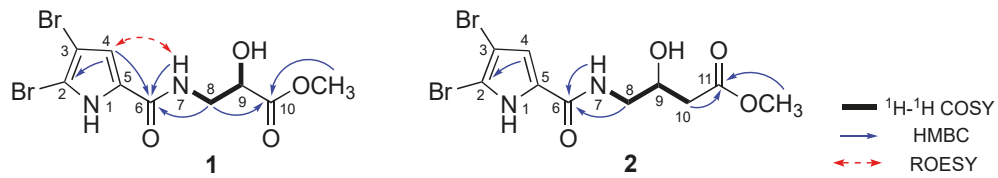

Figure 2. Key two-dimensional (2D) NMR correlations for agesasines A (1) and B (2).

The racemic nature of agesasines A (1) and B (2) indicated by their specific rotation values being nearly zero prompted us to perform the optical resolutions of $\mathbf{1}$ and $\mathbf{2}$. The analysis of $\mathbf{1}$ using the reversed phase chiral high performance liquid chromatography (HPLC) gave a pair of peaks in the integral ratio of ca. 1:1, indicating agesasine A (1) to be a racemate. Agesasine B (2) was also deduced to be a racemate, although the optical resolution could not be achieved in spite of attempts being made at various separation conditions.

9-Hydroxydihydrodispacamide (3) was obtained as a pale yellow amorphous solid. The HRESIMS showed an ion peak at $m / z 443.92824\left([\mathrm{M}-\mathrm{H}+\mathrm{Na}]^{+}, \Delta-0.04 \mathrm{mmu}\right)$, suggesting the molecular formula of $\mathrm{C}_{11} \mathrm{H}_{14} \mathrm{~N}_{5} \mathrm{O}_{3} \mathrm{Br}_{2}$. The ${ }^{1} \mathrm{H}$ and ${ }^{13} \mathrm{C}$ NMR spectra of 3 (Table 2) were similar to those of a known linear bromopyrrole alkaloid, dihydrodispacamide [17], except for the presence of an oxygenated methine signal (CH-9) in 3. Therefore, 3 was deduced to be a hydroxylated derivative of dihydrodispacamide. The presence of the hydroxy group at C-9 was confirmed by ${ }^{1} \mathrm{H}-{ }^{1} \mathrm{H}$ COSY cross-peaks of $\mathrm{H}_{2}-8 / \mathrm{H}-9$ and $\mathrm{H}-9 / \mathrm{H}_{2}-10$ (Figure 3). The relative configuration of 3 was not assigned in this study, while the racemic nature of $\mathbf{3}$ was confirmed by HPLC analysis with chiral column with a similar manner as for $\mathbf{1}$.

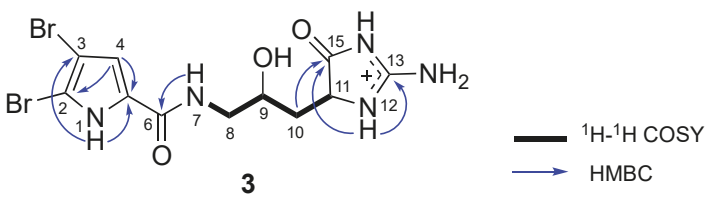

Figure 3. Selected 2D NMR correlations for 9-hydroxydihydrodispacamide (3). 
Table 2. 1D NMR data for 9-hydroxydihydrodispacamide (3), 9-hydroxydihydrooroidin (4), and $9 E$-keramadine (5) in DMSO- $d_{6}$.

\begin{tabular}{|c|c|c|c|c|c|c|}
\hline \multirow{2}{*}{ Position } & \multicolumn{2}{|r|}{3} & \multicolumn{2}{|r|}{4} & \multicolumn{2}{|r|}{5} \\
\hline & ${ }^{13} \mathrm{C}$ & ${ }^{1} \mathrm{H}(J$ in $\mathrm{Hz})$ & ${ }^{13} \mathrm{C}$ & ${ }^{1} \mathrm{H}(J$ in $\mathrm{Hz})$ & ${ }^{13} \mathrm{C}$ & ${ }^{1} \mathrm{H}(J$ in $\mathrm{Hz})$ \\
\hline 1 & - & 12.66 (brs) & - & 12.66 (brs) & - & 11.83 (brs) \\
\hline 2 & 104.7 & - & 104.8 & - & 121.6 & $6.98(\mathrm{dd}, 2.9,1.6)$ \\
\hline 3 & 98.0 & - & 98.2 & - & 95.2 & - \\
\hline 4 & 113.1 & $6.94(\mathrm{~d}, 2.8)$ & 113.2 & $6.86(\mathrm{~s})$ & 111.8 & $6.92(\mathrm{~s})$ \\
\hline 5 & 128.3 & - & 128.4 & - & 126.9 & - \\
\hline 6 & 159.3 & - & 159.4 & - & 159.7 & - \\
\hline 7 & - & $8.15(t, 5.9)$ & - & $8.19(t, 5.6)$ & - & $8.40(t, 5.5)$ \\
\hline 8 & 45.3 & $3.18(2 \mathrm{H}, \mathrm{m})$ & 44.8 & $3.23(\mathrm{~m}), 3.16(\mathrm{~m})$ & 40.4 & $3.99(2 \mathrm{H}, \mathrm{t}, 5.5)$ \\
\hline 9 & 66.3 & $3.79(\mathrm{~m})$ & 68.4 & $3.76(\mathrm{~m})$ & 130.8 & $6.19(\mathrm{dt}, 16.1,5.5)$ \\
\hline 10 & 34.8 & $\begin{array}{r}1.96(\mathrm{ddd}, 14.4,5.5,2.6) \\
1.71(\mathrm{ddd}, 14.4,10.9,5.5)\end{array}$ & 30.1 & $\begin{array}{l}2.57(\mathrm{dd}, 15.2,4.2) \\
2.40(\mathrm{dd}, 15.2,7.8)\end{array}$ & 115.3 & $6.30(\mathrm{~d}, 16.1)$ \\
\hline 11 & 56.8 & $4.34(\mathrm{t}, 5.5)$ & 124.3 & - & 126.6 & - \\
\hline 12 & - & 9.47 (brs) & - & 11.95 (brs) & & \\
\hline 13 & 158.2 & - & 147.1 & - & 146.9 & - \\
\hline 14 & - & nd & - & 11.87 (brs) & - & 12.35 (brs) \\
\hline 15 & 175.6 & - & 110.1 & 6.58 (brs) & 109.4 & 7.14 (brs) \\
\hline$N-\mathrm{Me}$ & & & & & 29.8 & $3.38(3 \mathrm{H}, \mathrm{s})$ \\
\hline $13-\mathrm{NH}_{2}$ & - & nd & - & 7.35 (2 H, brs) & - & 7.71 (2 H, brs) \\
\hline
\end{tabular}

nd: Not detected.

9-Hydroxydihydrooroidin (4) was obtained as a pale yellow amorphous solid. Although the ${ }^{1} \mathrm{H}$ and ${ }^{13} \mathrm{C}$ NMR spectra (Table 2) implied that 4 was a bromopyrrole alkaloid related to dihydrooroidin [17], the signals of an oxygenated methine $\left(\mathrm{CH}-9, \delta_{\mathrm{H}} 3.76\right.$, and $\left.\delta_{\mathrm{C}} 68.4\right)$ were observed in 4 . In the ${ }^{1} \mathrm{H}-{ }^{1} \mathrm{H}$ COSY spectrum, the oxygenated methine proton (H-9) showed cross-peaks with $\mathrm{H}_{2}-8$ and $\mathrm{H}_{2}-10$ (Figure 4). Based on the above findings and the molecular formula of $4, \mathrm{C}_{11} \mathrm{H}_{14} \mathrm{~N}_{5} \mathrm{O}_{2} \mathrm{Br}_{2}$, obtained by the HRESIMS ( $m / z 405.9510\left[\mathrm{M}^{+}, \Delta-0.4 \mathrm{mmu}\right), 4$ was assigned as 9-hydroxydihydrooroidin (Figure 1). A nearly zero value of the specific rotation indicated 4 to be a racemate, which was supported by the fact that 4 showed no cotton effect in the electronic circular dichroism (ECD) spectrum.
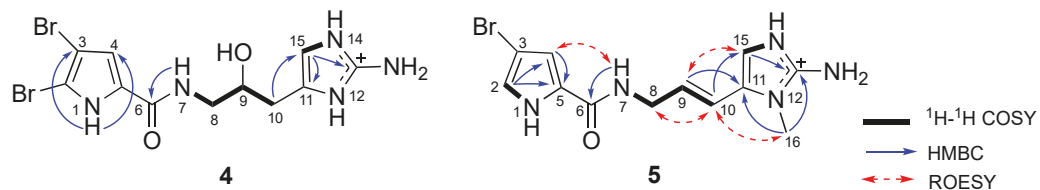

Figure 4. Selected 2D NMR correlations for 9-hydroxydihydrooroidin (4) and 9E-keramadine (5).

9E-Keramadine (5) displayed the ${ }^{1} \mathrm{H}$ and ${ }^{13} \mathrm{C}$ NMR spectra (Table 2) similar to those of a known bromopyrrole alkaloid possessing a 3-bromopyrrolecarboxamide moiety, keramadine [14]. The HRESIMS revealed the molecular formula of 5 to be $\mathrm{C}_{12} \mathrm{H}_{15} \mathrm{~N}_{5} \mathrm{OBr}$, which was identical to that of keramadine. However, the ${ }^{3} J(\mathrm{H}-9 / \mathrm{H}-10)$ value $(J=16.1 \mathrm{~Hz})$ in 5 indicated the geometry of the double bond to be $E$, whereas keramadine has the Z-olefin. The E-geometry was further underpinned by rotating frame nuclear Overhauser effect spectroscopy (ROESY) correlations for $\mathrm{H}-9 / \mathrm{H}-15$ and $\mathrm{H}_{2}-8 / \mathrm{H}-10$ (Figure 4). This is the first report of $9 E$-keramadine from a natural source, although the synthesis of 9E-keramadine has been reported to date [18].

Bromopyrrole alkaloids isolated from marine sponges have attracted the interest of researchers due to their diverse chemical structures. Various intriguing biological activities of bromopyrrole alkaloids leading drug discovery such as cytotoxic, antibacterial (antibiofilm), and protein kinase C modulating activities have been reported $[19,20]$. We have also reported the isolation of antimicrobial bromopyrrole alkaloids to date [6]. In this study, the antiproliferative activity of 1-5 against human cancer cell lines (HeLa, A549, and MCF7) were evaluated, showing no cytotoxicity against all cell lines $\left(\mathrm{IC}_{50}>100 \mu \mathrm{M}\right)$ (Figures S43-S45). 
In conclusion, five new bromopyrrole alkaloids, agesasines A (1) and B (2), 9-hydroxydihydrodispacamide (3), 9-hydroxydihydrooroidin (4), and 9E-keramadine (5) were isolated from Okinawan marine sponges Agelas spp. Typical bromopyrrole alkaloids such as oroidin [12,13] and keramadine [14] consist of a mono or dibrominated pyrrolecarboxamide moiety and an aminoimidazole moiety linked through $\mathrm{C}_{3}$ unit. In contrast, agesasines $\mathrm{A}(\mathbf{1})$ and $\mathrm{B}(\mathbf{2})$ are rare bromopyrrole alkaloids lacking an aminoimidazole moiety, whereas $\mathbf{1}$ and $\mathbf{2}$ might be artifacts during the extraction and isolation process with acidic condition. Few alkaloids with such structural feature have been isolated from marine sponges Agelas spp. collected off the South China Sea [21,22].

\section{Materials and Methods}

\subsection{General Procedures}

Optical rotations were obtained on a JASCO P-2200 digital polarimeter (JASCO Co., Tokyo, Japan). UV spectra were recorded on a Hitachi U-3900H spectrophotometer (Hitachi, Ltd., Tokyo, Japan). NMR spectra were measured by a Bruker AVANCE-500 instrument (Bruker, Billerica, MA, USA) using tetramethylsilane as an internal standard. HRESIMS were recorded on a Waters LCT PREMIER 2695 (Waters Co., Milford, MA, USA) and a JEOL JMS-T100LP (JEOL, Ltd., Tokyo, Japan). Column chromatography was performed with silica gel $60 \mathrm{~N}$ (Kanto Kagaku, Tokyo, Japan) and Diaion HP-20 (Mitsubishi Chemical, Tokyo, Japan). Medium pressure liquid chromatography (MPLC) was carried out on Toyopearl HW-40F (TOSOH Co., Tokyo, Japan), MCI gel CHP20P (Mitsubishi Chemical, Tokyo, Japan), and Biotage SNAP Cartridge KP-C18-HS (Biotage, Uppsala, Sweden).

\subsection{Materials}

The marine sponges Agelas spp. were collected off Kerama Islands, Okinawa, and identified by one of the authors (N.T.). The voucher specimens (SS-516 and SS-1302) were deposited in the Graduate School of Pharmaceutical Sciences, Tokushima University.

\subsection{Extraction and Isolation}

The marine sponges Agelas spp. SS-516 (5.22 kg, wet weight) and SS-1302 (3.42 kg, wet weight) were separately extracted with $\mathrm{MeOH}$ to give the extracts (197.1 and $376.3 \mathrm{~g}$, respectively), each of which was partitioned with $n$-hexane and $90 \% \mathrm{MeOH}$ aq. The $90 \% \mathrm{MeOH}$ aq.-soluble materials of SS-516 were separated by column chromatography on Diaion HP-20 $\left(\mathrm{MeOH} / \mathrm{H}_{2} \mathrm{O}, 0: 100-100: 0\right)$ to give six fractions (frs. 1-6). Fr. 3 was subjected to silica gel column chromatography $\left(\mathrm{CHCl}_{3} / \mathrm{MeOH} / \mathrm{TFA}\right.$, 95:5:0.1-80:20:0.1) to yield 12 fractions (frs. 3.1-3.12). Fr. 3.7 was applied to ODS MPLC $\left(\mathrm{MeCN} / \mathrm{H}_{2} \mathrm{O} / \mathrm{TFA}\right.$, 5:95:0.1-80:20:0.1), and then purified by ODS HPLC (YMC Hydrosphere C18, $\left.\phi 20 \times 250 \mathrm{~mm}, \mathrm{MeCN} / \mathrm{H}_{2} \mathrm{O} / \mathrm{TFA}, 35: 65: 0.1\right)$ to furnish agesasines A (1, $\left.2.5 \mathrm{mg}\right)$ and B (2, $\left.2.2 \mathrm{mg}\right)$. Separation of fr. 3.11 by ODS MPLC $\left(\mathrm{MeCN} / \mathrm{H}_{2} \mathrm{O} / \mathrm{TFA}\right.$, 5:95:0.1-80:20:0.1) gave five fractions (frs. 3.11.1-3.11.5). Tauroacidin A (124.1 mg) and taurodispacamide A (34.5 mg) were purified from fr. 3.11.3 by ODS MPLC (MeCN/ $\left.\mathrm{H}_{2} \mathrm{O} / \mathrm{TFA}, 20: 80: 0.1\right)$.

The $90 \% \mathrm{MeOH}$ aq.-soluble materials of SS-1302 were further partitioned between $n$ - $\mathrm{BuOH}$ and water. The $n$ - $\mathrm{BuOH}$-soluble materials ( $58.0 \mathrm{~g}$ ) were applied to silica gel column chromatography $\left(\mathrm{CHCl}_{3} / \mathrm{MeOH} / \mathrm{TFA}, 9: 1: 0.1-5: 5: 0.1\right)$ to give six fractions (frs. $\left.1^{\prime}-6^{\prime}\right)$ including oroidin (17.1 g, fr. $\left.3^{\prime}\right)$. Fr. $4^{\prime}$ was subjected to MPLC on a Toyopearl HW-40F column $\left(\mathrm{MeOH} / \mathrm{H}_{2} \mathrm{O} / \mathrm{TFA}\right.$, 10:90:0.1-90:10:0.1), an MCI gel CHP 20P column ( $\left.\mathrm{MeOH} / \mathrm{H}_{2} \mathrm{O} / \mathrm{TFA}, 10: 90: 0.1-90: 10: 0.1\right)$ to yield seven fractions (frs. $4^{\prime}$.4.1-4'.4.7). Fr. $4^{\prime} .4 .3$ was loaded to MPLC on an ODS column (MeCN/ $\left.\mathrm{H}_{2} \mathrm{O} / \mathrm{TFA}, 10: 90: 0.1-60: 40: 0.1\right)$ to give six fractions (frs. $4^{\prime} .4 .3 .1-4^{\prime} .4 .3 .6$ ), and then fr. $4^{\prime} .4 .3 .3$ was purified by ODS HPLC (COSMOSIL $5 \mathrm{C}_{18}$-MS-II, $\left.\phi 20 \times 250 \mathrm{~mm}, \mathrm{MeCN} / \mathrm{H}_{2} \mathrm{O} / \mathrm{TFA}, 17: 83: 0.1\right)$. Further purification of fr. $4^{\prime} .4 .3 .3 .2$ on ODS HPLC (YMC Hydrosphere C18, $\phi 10 \times 250 \mathrm{~mm}, \mathrm{MeCN} / \mathrm{H}_{2} \mathrm{O} / \mathrm{TFA}, 13: 87: 0.1$ ) afforded 9-hydroxydihydrodispacamide (3, $5.0 \mathrm{mg}), 9 E$-keramadine $(5,3.1 \mathrm{mg})$, and keramadine (6.7 $\mathrm{mg})$. 9-Hydroxydihydrooroidin $(4,2.1 \mathrm{mg}$ ) was isolated from fr. 4' 4.3.3.3 by ODS HPLC (YMC Hydrosphere 
C18, ф $\left.10 \times 250 \mathrm{~mm}, \mathrm{MeCN} / \mathrm{H}_{2} \mathrm{O} / \mathrm{TFA}, 13: 87: 0.1\right)$. Fr. $4^{\prime} .4 .4$ was subjected to ODS MPLC $\left(\mathrm{MeCN} / \mathrm{H}_{2} \mathrm{O} / \mathrm{TFA}, 10: 90: 0.1-50: 50: 0.1\right)$ and then ODS HPLC (YMC Hydrosphere C18, $\phi 10 \times 250 \mathrm{~mm}$, $\left.\mathrm{MeCN} / \mathrm{H}_{2} \mathrm{O} / \mathrm{TFA}, 15: 85: 0.1\right)$ to furnish 2-bromo-9,10-dihydrokeramadine (2.1 mg). Fr. 5' was applied to MPLC on a Toyopearl HW-40F column $\left(\mathrm{MeOH} / \mathrm{H}_{2} \mathrm{O} / \mathrm{TFA}, 10: 90: 0.1-90: 10: 0.1\right)$ to give eight fractions (frs. $\left.5^{\prime} .1-5^{\prime} .8\right)$. Fr. $5^{\prime}$ was passed through an MCI gel CHP $20 \mathrm{P}$ column $\left(\mathrm{MeOH} / \mathrm{H}_{2} \mathrm{O} / \mathrm{TFA}\right.$, 10:90:0.1-100:0:0.1) and an ODS column ( $\left.\mathrm{MeOH} / \mathrm{H}_{2} \mathrm{O} / \mathrm{TFA}, 10: 90: 0.1-0: 10: 0.1\right)$ to afford nagelamide $\mathrm{L}$ $(187.5 \mathrm{mg})$. Tauroacidin A and nagelamide L did not show optical rotations.

Agesasine A (1): Pale yellow amorphous solid; $[\alpha]_{\mathrm{D}}^{28} 0$ (c 0.10, MeOH); UV (MeOH) $\lambda_{\max } 275$ ( $\varepsilon$ 4900) $\mathrm{nm} ;{ }^{1} \mathrm{H}$ and ${ }^{13} \mathrm{C}$ NMR data (Table 1); ESIMS: $\mathrm{m} / \mathrm{z}$ 391, 393, and 395 (1:2:1), [M + Na $]^{+}$; HRESIMS: $\mathrm{m} / \mathrm{z}$ $390.89045[\mathrm{M}+\mathrm{Na}]^{+}$(calcd for $\mathrm{C}_{9} \mathrm{H}_{10} \mathrm{~N}_{2} \mathrm{O}_{4} \mathrm{Na}^{79} \mathrm{Br}_{2}, 390.89050$ ).

Agesasine B (2): Pale yellow amorphous solid; $[\alpha]_{\mathrm{D}}^{28} 0$ (c 0.10, MeOH); UV (MeOH) $\lambda_{\max } 274$ ( $\left.\varepsilon 3100\right)$ $\mathrm{nm} ;{ }^{1} \mathrm{H}$ and ${ }^{13} \mathrm{C}$ NMR data (Table 1); ESIMS: $\mathrm{m} / \mathrm{z}$ 381, 383, and 385 (1:2:1), [M - H] ${ }^{-}$; HRESIMS: $\mathrm{m} / \mathrm{z}$ $380.9088[\mathrm{M}-\mathrm{H}]^{-}$(calcd for $\mathrm{C}_{10} \mathrm{H}_{11} \mathrm{~N}_{2} \mathrm{O}_{4}{ }^{79} \mathrm{Br}_{2}, 380.9086$ ).

9-Hydroxydihydrodispacamide (3): Pale yellow amorphous solid; $[\alpha]_{\mathrm{D}}^{27} 0$ (c 0.10, $\left.\mathrm{MeOH}\right) ; \mathrm{UV}(\mathrm{MeOH})$ $\lambda_{\max } 223$ ( $\varepsilon$ 3900) and 275 (3400) nm; ${ }^{1} \mathrm{H}$ and ${ }^{13} \mathrm{C}$ NMR data (Table 2); ESIMS: $m / z$ 444, 446, and 448 (1:2:1), $[\mathrm{M}-\mathrm{H}+\mathrm{Na}]^{+}$; HRESIMS: $m / z 443.92824[\mathrm{M}-\mathrm{H}+\mathrm{Na}]^{+}$(calcd for $\mathrm{C}_{11} \mathrm{H}_{13} \mathrm{~N}_{5} \mathrm{O}_{3} \mathrm{Na}^{79} \mathrm{Br}_{2}$, 443.92828).

9-Hydroxydihydrooroidin (4): Pale yellow amorphous solid; $[\alpha]_{\mathrm{D}}^{27} 0$ (c 0.10, MeOH); UV (MeOH) $\lambda_{\max }$ 276 ( $\varepsilon$ 3900) $\mathrm{nm} ;{ }^{1} \mathrm{H}$ and ${ }^{13} \mathrm{C}$ NMR data (Table 2); ESIMS: $m / z$ 406, 408, and 410 (1:2:1), [M] ${ }^{+}$; HRESIMS: $m / z 405.9510[\mathrm{M}]^{+}$(calcd for $\mathrm{C}_{11} \mathrm{H}_{14} \mathrm{~N}_{5} \mathrm{O}_{2}{ }^{79} \mathrm{Br}_{2}, 405.9514$ ).

9E-Keramadine (5): Pale yellow amorphous solid; UV (MeOH) $\lambda_{\max } 271(\varepsilon 3300) \mathrm{nm} ;{ }^{1} \mathrm{H}$ and ${ }^{13} \mathrm{C}$ NMR data (Table 2); ESIMS: $m / z 324$ and $326(1: 1)$, [M] $^{+}$; HRESIMS: $m / z 324.04592$ [M] ${ }^{+}$(calcd for $\left.\mathrm{C}_{12} \mathrm{H}_{15} \mathrm{~N}_{5} \mathrm{O}^{79} \mathrm{Br}, 324.04600\right)$.

\subsection{Optical Resolutions of $\mathbf{1}-\mathbf{3}$}

Optical resolutions of agesasine A (1) and 9-hydroxydihydrodispacamide (3), were performed on chiral HPLC (Chiral ART Cellulose-SB, YMC, $\phi 4.6 \times 250 \mathrm{~mm}$, flow rate $0.5 \mathrm{~mL} / \mathrm{min}$, UV detection $254 \mathrm{~nm}$ ) at $35^{\circ} \mathrm{C}$ with elution of $\mathrm{MeOH} / \mathrm{MeCN} / \mathrm{H}_{2} \mathrm{O} / \mathrm{H}_{3} \mathrm{PO}_{4}$ (30:10:60:0.1 for 1; 8:2:90:0.1 for 3) to give enantiomers in the integral ratio of ca. $1: 1\left(t_{R} 27.5\right.$ and $29.0 \mathrm{~min}$ for $1 ; t_{R} 12.5$ and $14.3 \mathrm{~min}$ for 3) in each case. The separations of enantiomers were confirmed by MS analyses. Separated peaks for enantiomers of agesasine B (2) could not be obtained in any condition in this study.

\subsection{Evaluation for Antiproliferative Activity of 1-5}

New bromopyrrole alkaloids $\mathbf{1 - 5}$ were evaluated for their antiproliferative activity against human cancer cell lines (HeLa, A549, and MCF7) according to the following procedure. The human cancer cell lines were cultured in Dulbecco's modified eagle medium (DMEM) supplemented with 5\% fetal bovine serum (FBS). All cells were incubated at $37{ }^{\circ} \mathrm{C}$ in a humidified atmosphere with $5 \%$ $\mathrm{CO}_{2}-95 \%$ air. Cells were seeded at $1 \times 10^{4}$ cells/well in a 96-well plate and preincubated for $24 \mathrm{~h}$. Test samples were dissolved in small amounts of DMSO and diluted in the appropriate culture medium (final concentration of DMSO < 1\%). After removal of the preincubated culture medium, $100 \mu \mathrm{L}$ of medium containing various concentrations of test compound was added and further incubated for $48 \mathrm{~h}$. A cell proliferation assay was performed with the Cell Counting Kit-8 (WST-8; Dojindo, Japan) according to the manufacturer's instruction. Briefly, the WST-8 reagent solution $(10 \mu \mathrm{L})$ was added to each well of a 96-well microplate containing $100 \mu \mathrm{L}$ of cells in the culture medium at various densities, and the plate was incubated for $2 \mathrm{~h}$ at $37^{\circ} \mathrm{C}$. Absorbance was measured at $450 \mathrm{~nm}$ using a microplate reader. Cisplatin was used as a positive control, whose $\mathrm{IC}_{50}$ values against HeLa, A549, and MCF7 cells were $11.7,7.2$, and $52.4 \mathrm{mM}$, respectively. 
Supplementary Materials: The following are available online at http://www.mdpi.com/1660-3397/18/9/455/s1. Figure S1: ${ }^{1} \mathrm{H}$ NMR spectrum of agesasine A (1) in DMSO- $d_{6}(500 \mathrm{MHz})$, Figure S2: ${ }^{13} \mathrm{C}$ NMR spectrum of agesasine A (1) in DMSO- $d_{6}(125 \mathrm{MHz})$, Figure S3: ${ }^{1} \mathrm{H}^{-1} \mathrm{H}$ COSY spectrum of agesasine A (1) in DMSO- $d_{6}$ $(500 \mathrm{MHz})$, Figure S4: HSQC spectrum of agesasine A (1) in DMSO- $d_{6}(500 \mathrm{MHz})$, Figure S5: HMBC spectrum of agesasine A (1) in DMSO- $d_{6}(500 \mathrm{MHz})$, Figure S6: ROESY spectrum of agesasine A (1) in DMSO- $d_{6}$ (500 MHz), Figure S7: HRESIMS spectrum (pos.) of agesasine A (1), Figure S8: Chiral HPLC chart of agesasine A (1), Figure S9: ${ }^{1} \mathrm{H}$ NMR spectrum of agesasine B (2) in DMSO- $d_{6}(500 \mathrm{MHz})$, Figure S10: ${ }^{13} \mathrm{C}$ NMR spectrum of agesasine B (2) in DMSO- $d_{6}(125 \mathrm{MHz})$, Figure S11: ${ }^{1} \mathrm{H}-{ }^{1} \mathrm{H}$ COSY spectrum of agesasine B (2) in DMSO- $d_{6}(500 \mathrm{MHz})$, Figure S12: HSQC spectrum of agesasine B (2) in DMSO- $d_{6}(500 \mathrm{MHz})$, Figure S13: HMBC spectrum of agesasine B (2) in DMSO- $d_{6}(500 \mathrm{MHz})$, Figure S14: HRESIMS spectrum (neg.) of agesasine B (2), Figure S15: ${ }^{1} \mathrm{H}$ NMR spectrum of 9-hydroxydihydrodispacamide (3) in DMSO- $d_{6}$ (500 MHz), Figure S16: ${ }^{13} \mathrm{C}$ NMR spectrum of 9-hydroxydihydrodispacamide (3) in DMSO- $d_{6}(125 \mathrm{MHz})$, Figure S17: ${ }^{1} \mathrm{H}-{ }^{1} \mathrm{H}$ COSY spectrum of 9-hydroxydihydrodispacamide (3) in DMSO- $d_{6}(500 \mathrm{MHz})$, Figure S18: HSQC spectrum of 9-hydroxydihydrodispacamide (3) in DMSO- $d_{6}$ (500 MHz), Figure S19: HMBC spectrum of 9-hydroxydihydrodispacamide (3) in DMSO- $d_{6}(500 \mathrm{MHz})$, Figure S20: HRESIMS spectrum (pos.) of 9-hydroxydihydrodispacamide (3), Figure S21: Chiral HPLC chart of 9-hydroxydihydrodispacamide (3), Figure S22: ${ }^{1} \mathrm{H}$ NMR spectrum of 9-hydroxydihydrooroidin (4) in DMSO- $d_{6}(500 \mathrm{MHz})$, Figure S23: ${ }^{13} \mathrm{C}$ NMR spectrum of 9-hydroxydihydrooroidin (4) in DMSO- $d_{6}(125 \mathrm{MHz})$, Figure S24: ${ }^{1} \mathrm{H}-{ }^{1} \mathrm{H}$ COSY spectrum of 9-hydroxydihydrooroidin (4) in DMSO- $d_{6}(500 \mathrm{MHz})$, Figure S25: HSQC spectrum of 9-hydroxydihydrooroidin (4) in DMSO- $d_{6}(500 \mathrm{MHz})$, Figure S26: HMBC spectrum of 9-hydroxydihydrooroidin (4) in DMSO- $d_{6}(500 \mathrm{MHz})$, Figure S27: HRESIMS spectrum (pos.) of 9-hydroxydihydrooroidin (4), Figure S28: ECD spectrum of 9-hydroxydihydrooroidin (4) in $\mathrm{MeOH}$, Figure S29: ${ }^{1} \mathrm{H}$ NMR spectrum of 9E-keramadine (5) in DMSO- $d_{6}$ $(500 \mathrm{MHz})$, Figure S30: ${ }^{13} \mathrm{C}$ NMR spectrum of $9 E$-keramadine (5) in DMSO- $d_{6}(125 \mathrm{MHz})$, Figure S31: ${ }^{1} \mathrm{H}_{-}{ }^{1} \mathrm{H}$ COSY spectrum of $9 E$-keramadine (5) in DMSO- $d_{6}(500 \mathrm{MHz}$ ), Figure S32: HSQC spectrum of 9E-keramadine (5) in DMSO- $d_{6}(500 \mathrm{MHz})$, Figure S33: HMBC spectrum of 9E-keramadine (5) in DMSO- $d_{6}(500 \mathrm{MHz})$, Figure S34: ROESY spectrum of $9 E$-keramadine (5) in DMSO- $d_{6}(500 \mathrm{MHz})$, Figure S35: HRESIMS spectrum (pos.) of 9E-keramadine (5), Figure S36: ${ }^{1} \mathrm{H}$ NMR spectrum of tauroacidin A in DMSO- $d_{6}(500 \mathrm{MHz})$, Figure S37: ${ }^{1} \mathrm{H}$ NMR spectrum of taurodispacamide A in DMSO- $d_{6}(500 \mathrm{MHz})$, Figure S38: ${ }^{1} \mathrm{H}$ NMR spectrum of oroidin in DMSO- $d_{6}$ $(500 \mathrm{MHz})$, Figure S39: ${ }^{1} \mathrm{H}$ NMR spectrum of keramadine in DMSO- $d_{6}(500 \mathrm{MHz})$, Figure S40: ${ }^{1} \mathrm{H}$ NMR spectrum of 2-bromo-9,10-dihydrokeramadine in DMSO- $d_{6}(500 \mathrm{MHz})$, Figure S41: ${ }^{1} \mathrm{H}$ NMR spectrum of nagelamide $\mathrm{L}$ in DMSO- $d_{6}(500 \mathrm{MHz})$, Figure S42: Structures of known bromopyrrole alkaloids, tauroacidin A, taurodispacamide A, oroidin, keramadine, 2-bromokeramadine, and nagelamide L, Figure S43: Antiproliferative activity of 1-5 against HeLa cells, Figure S44: Antiproliferative activity of 1-5 against A549 cells, Figure S45: Antiproliferative activity of 1-5 against MCF7 cells, Table S1: 1D and 2D NMR data for agesasine A (1) in DMSO- $d_{6}$, Table S2: 1D and 2D NMR data for agesasine B (2) in DMSO- $d_{6}$, Table S3: 1D and 2D NMR data for 9-hydroxydihydrodispacamide (3) in DMSO- $d_{6}$, Table S4: 1D and 2D NMR data for 9-hydroxydihydrooroidin (4) in DMSO- $d_{6}$, Table S5: 1D and 2D NMR data for 9E-keramadine (5) in DMSO- $d_{6}$, Table S6: ${ }^{1} \mathrm{H}$ NMR data for tauroacidin A and taurodispacamide A in DMSO- $d_{6}$, Table S7: ${ }^{1} \mathrm{H}$ NMR data for oroidin, keramadine, and 2-bromo-9,10-dihydrokeramadine in DMSO- $d_{6}$, Table S8: ${ }^{1} \mathrm{H}$ NMR data for nagelamide L in DMSO- $d_{6}$.

Author Contributions: Conceptualization, S.L., N.T., D.T., S.-Y.K., M.K., K.I., J.K., and Y.K.; methodology, S.L. and N.T.; validation, S.L. and N.T.; formal analysis, S.L., N.T., and Y.K.; investigation, S.L., S.T., D.T., and S.-Y.K.; resources, J.K.; writing—original draft preparation, S.L.; writing—review and editing, N.T., M.K., K.I., and Y.K. All authors have read and agreed to the published version of the manuscript.

Funding: This work was partly supported by JSPS KAKENHI, grant number JP17K08337.

Acknowledgments: We thank Z. Nagahama for his help with the sponge collection.

Conflicts of Interest: The authors declare no conflict of interest.

\section{References}

1. Carroll, A.R.; Copp, B.R.; Davis, R.A.; Keyzers, R.A.; Prinsep, M.R. Marine natural products. Nat. Prod. Rep. 2020, 37, 175-223. [CrossRef] [PubMed]

2. Laport, M.S.; Santos, O.C.S.; Muricy, G. Marine sponges: Potential sources of new antimicrobial drugs. Curr. Pharm. Biotechnol. 2009, 10, 86-105. [CrossRef] [PubMed]

3. Paul, V.J.; Puglisi, M.P. Chemical mediation of interactions among marine organisms. Nat. Prod. Rep. 2004, 21, 189-209. [CrossRef] [PubMed]

4. Paul, V.J.; Puglisi, M.P.; Ritson-Williams, R. Marine chemical ecology. Nat. Prod. Rep. 2006, 23, $153-180$. [CrossRef]

5. Braekman, J.-C.; Daloze, D.; Stoller, C.; Van Soest, R.W.M. Chemotaxonomy of Agelas (Polifera: Demospongiae). Biochem. Syst. Ecol. 1992, 20, 417-431. [CrossRef] 
6. Tanaka, N.; Kusama, T.; Kashiwada, Y.; Kobayashi, J. Bromopyrrole alkaloids from Okinawan marine sponges Agelas spp. Chem. Pharm. Bull. 2016, 64, 691-694. [CrossRef]

7. Kusama, T.; Tanaka, T.; Sakai, K.T.; Gonoi, T.; Fromont, J.; Kashiwada, Y.; Kobayashi, J. Agelamadins A and B, dimeric bromopyrrole alkaloids from a marine sponge Agelas sp. Org. Lett. 2014, 16, 3916-3918. [CrossRef]

8. Kusama, T.; Tanaka, N.; Sakai, K.; Gonoi, T.; Fromont, J.; Kashiwada, Y.; Kobayashi, J. Agelamadins C-E, bromopyrrole alkaloids comprising oroidin and 3-hydroxykynurenine from a marine sponge Agelas sp. Org. Lett. 2014, 16, 5176-5179. [CrossRef]

9. Lee, S.; Tanaka, N.; Kobayashi, J.; Kashiwada, Y. Agelamasines A and B, diterpene alkaloids from an Okinawan marine sponge Agelas sp. J. Nat. Med. 2018, 72, 364-368. [CrossRef]

10. Kobayashi, J.; Inaba, K.; Tsuda, M. Tauroacidins A and B, new bromopyrrole alkaloids possessing a taurine residue from Hymeniacidon sponge. Tetrahedron 1997, 53, 16679-16682. [CrossRef]

11. Fattorusso, E.; Taglialatela-Scafati, O. Two novel pyrrole-imidazle alkaloids from the Mediterranean sponge Agelas oroides. Tetrahedron Lett. 2000, 41, 9917-9922. [CrossRef]

12. Forenza, S.; Minale, L.; Riccio, R.; Fattorusso, E. New bromo-pyrrole derivatives from the sponge Agelas oroides. J. Chem. Soc. D Chem. Commun. 1971, 1129-1130. [CrossRef]

13. Ando, N.; Terashima, S. A novel synthesis of the 2-amino- $1 H$-imidazol-4-carbaldehyde derivatives and its application to the efficient synthesis of 2-aminoimidazole alkaloids, oroidin, hymenidin, dispacamide, monobromodispacamide, ageladine A. Tetrahedron 2010, 66, 6224-6237. [CrossRef]

14. Nakamura, H.; Ohizumi, Y.; Kobayashi, J.; Hirata, Y. Keramadine, a novel antagonist of serotonergic receptors isolated from the Okinawan sea sponge Agelas sp. Tetrahedron Lett. 1984, 25, 2475-2478. [CrossRef]

15. Kusama, T.; Tanaka, N.; Takahashi-Nakaguchi, A.; Gonoi, T.; Fromont, J.; Kobayashi, J. Bromopyrrole alkaloids from a marine sponge Agelas sp. Chem. Pharm. Bull. 2014, 62, 499-503. [CrossRef]

16. Araki, A.; Kubota, T.; Tsuda, M.; Mikami, Y.; Fromont, J.; Kobayashi, J. Nagelamides K and L, Dimeric Bromopyrrole Alkaloids from Sponge Agelas Species. Org. Lett. 2008, 10, 2099-2102. [CrossRef]

17. Olofson, A.; Yakushijin, K.; Horne, D.A. Synthesis of marine sponge alkaloids oroidin, clathrodin, and dispacamides. Preparation and transformation of 2-amino-4,5-dialkoxy-4,5-dihydroimidazolines from 2-aminoimidazoles. J. Org. Chem. 1998, 63, 1248-1253. [CrossRef]

18. Daninos-Zeghal, S.; Al Mourabit, A.; Ahond, A.; Poupat, C.; Potier, P. Synthèse de metabolites marins 2-aminoimidazoliques: Hyménidine, oroïdine et kéramadine. Tetrahedron 1997, 53, 7605-7614. [CrossRef]

19. Zhang, H.; Dong, M.; Chen, J.; Wang, H.; Tenney, K.; Crews, P. Bioactive secondary metabolites from the marine sponge genus Agelas. Mar. Drugs 2017, 15, 351. [CrossRef]

20. Al-Mourabit, A.; Zancanella, M.A.; Tilvi, S.; Romo, D. Biosynthesis, asymmetric synthesis, and pharmacology, including cellular targets, of the pyrrole-2-aminoimidazole marine alkaloids. Nat. Prod. Rep. 2011, 28, 1229-1260. [CrossRef]

21. Zhu, Y.; Wang, Y.; Gu, B.-B.; Yang, F.; Jiao, W.-H.; Hu, G.-H.; Yu, H.-B.; Han, B.-N.; Zhang, W.; Shen, Y.; et al. Antifungal bromopyrrole alkaloids from the South China sea sponge Agelas sp. Tetrahedron 2016, 72, 2964-2971. [CrossRef]

22. Chu, M.-J.; Tang, X.-L.; Qin, G.-F.; de Voogd, N.J.; Li, P.-L. Three new non-brominated pyrrole alkaloids from the South China sea sponge Agelas nakamurai. Chin. Chem. Lett. 2017, 28, 1210-1213. [CrossRef]

(C) 2020 by the authors. Licensee MDPI, Basel, Switzerland. This article is an open access article distributed under the terms and conditions of the Creative Commons Attribution (CC BY) license (http://creativecommons.org/licenses/by/4.0/). 
Article

\title{
Synthesis and Antimicrobial Evaluation of Side-Chain Derivatives based on Eurotiumide A
}

\author{
Atsushi Nakayama ${ }^{1, *}$, Hideo Sato ${ }^{1}$, Tenta Nakamura ${ }^{1}$, Mai Hamada ${ }^{1}$, Shuji Nagano ${ }^{1}$, \\ Shuhei Kameyama ${ }^{1}$, Yui Furue ${ }^{2}$, Naoki Hayashi ${ }^{2}$, Go Kamoshida ${ }^{2}$, Sangita Karanjit ${ }^{1}$, \\ Masataka Oda ${ }^{2}$ and Kosuke Namba ${ }^{1, *}$ \\ 1 Graduate School of Pharmaceutical Sciences and Research Cluster on "Innovative Chemical Sensing", \\ Tokushima University, 1-78-1 Shomachi, Tokushima 770-8505, Japan; hideo1995214@gmail.com (H.S.); \\ c401603069@tokushima-u.ac.jp (T.N.); c401403070@tokushima-u.ac.jp (M.H.); \\ c401941004@tokushima-u.ac.jp (S.N.); c401931030@tokushima-u.ac.jp (S.K.); \\ karanjit@tokushima-u.ac.jp (S.K.) \\ 2 Department of Microbiology and Infection Control Sciences, Kyoto Pharmaceutical University, \\ Misasaginakauchi-cho, Yamashita-Ku, Kyoto 607-8414, Japan; mametty1214@gmail.com (Y.F.); \\ nhayashi@mb.kyoto-phu.ac.jp (N.H.); kamoshida@mb.kyoto-phu.ac.jp (G.K.); \\ moda@mb.kyoto-phu.ac.jp (M.O.) \\ * Correspondence: anakaya@tokushima-u.ac.jp (A.N.); namba@tokushima-u.ac.jp (K.N.)
}

Received: 30 November 2019; Accepted: 29 January 2020; Published: 30 January 2020

\begin{abstract}
Side-chain derivatives of eurotiumide A, a dihydroisochroman-type natural product, have been synthesized and their antimicrobial activities described. Sixteen derivatives were synthesized from a key intermediate of the total synthesis of eurotiumide A, and their antimicrobial activities against two Gram-positive bacteria, methicillin-susceptible and methicillin-resistant Staphylococcus aureus (MSSA and MRSA), and a Gram-negative bacterium, Porphyromonas gingivalis, were evaluated. The results showed that derivatives having an iodine atom on their aromatic ring instead of the prenyl moiety displayed better antimicrobial activity than eurotiumide A against MSSA and P. gingivalis. Moreover, we discovered that a derivative with an isopentyl side chain, which is a hydrogenated product of eurotiumide $\mathrm{A}$, is the strongest antimicrobial agent against all three strains, including MRSA.
\end{abstract}

Keywords: antibiotics; natural product; P. gingivalis; methicillin-resistant S. aureus

\section{Introduction}

Humans have always struggled against infectious diseases [1-5] and in relatively recent times have developed various antimicrobial therapies [6-8]. Since the discovery of penicillin [9], various natural products having antimicrobial activity have been discovered [10-16], and the majority of clinically used antibiotics are either natural products, semisynthetic derivatives, or compounds derived from them [17-19]. Despite the presence of many excellent antibiotics, multidrug-resistant bacterial pathogens have emerged all over the world [20-22], and the development of novel and effective antimicrobial agents against many kinds of pathogenic bacteria, including methicillin-resistant Staphylococcus aureus (MRSA), should remain a continuous mission for medicinal chemists. In 2014, Wang and co-workers discovered eurotiumides, which are novel dihydroisocoumarin-type natural products, from a gorgonian-derived fungus, Eurotium sp. XS-200900E6 [23]. Among the series of eurotiumides, eurotiumide A (1), having cis configurations at $\mathrm{H} 3 / \mathrm{H} 4$, exhibited potent antimicrobial activities against Staphylococcus epidermidis, Bacillus cereus, Vibrio anguillarum, and Escherichia coli. Based on that report, although $\mathbf{1}$ seems to be an attractive seed compound for antibiotics, further antimicrobial investigation and a structure-activity relationship study of $\mathbf{1}$ are needed. In particular, because there is a chance that modification of the side chain of the aromatic ring could improve antimicrobial activity 
and the spectrum, a structure-activity relationship study of the substituent effect of the aromatic ring is essential for discovering promising candidates for antimicrobial agents. Recently, we reported the first asymmetric total syntheses of (-)-eurotiumide A (1) and (+)-eurotiumide B and revised their reported structures [24]. In our synthetic route, the prenyl side chain of the aromatic ring was introduced in the late stage by the Stille coupling reaction with the key intermediate 2 . Based on our previous results, we considered that a number of derivatives of $\mathbf{1}$, which have a variety of kinds of side-chain moiety, could be obtained from the common intermediate 2 and non-substituted compound 3 in the late stage of synthesis (Figure 1).

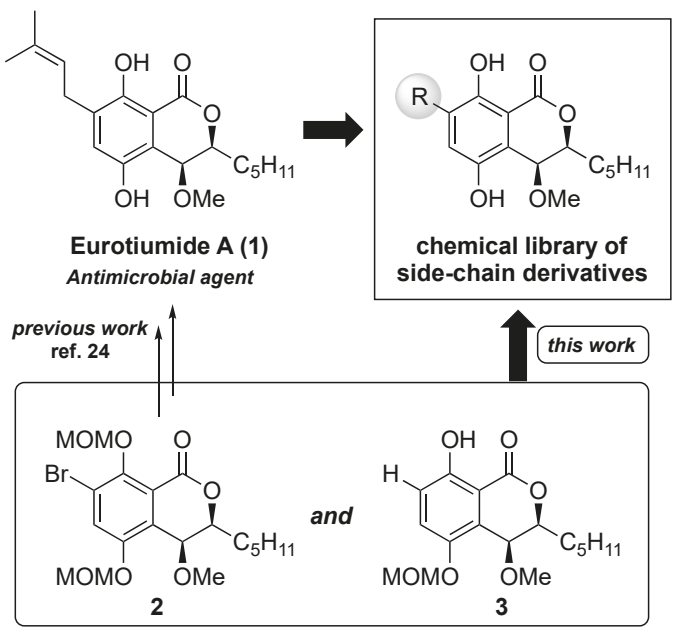

Figure 1. Concept of construction of the chemical library of the side chain-derivatives of eurotiumide A (1).

In this work, as part of our continuing research [24,25], we constructed a chemical library of the side-chain derivatives of eurotiumide A (1) to elucidate the effects of the side chains of the aromatic rings and to develop antimicrobial agents against methicillin-susceptible S. aureus (MSSA) and methicillin-resistant $S$. aureus (both Gram-positive bacteria), as well as Porphyromonas gingivalis (a Gram-negative bacterium).

\section{Results and Discussion}

\subsection{Synthesis of the Side-Chain Derivatives of Eurotiumide A}

Our synthetic plan is shown in Figure 2. We planned to introduce three types of functional groups: a hydrocarbon group, including hydrogen, alkyl, and aromatic rings (Type A); a heteroatom and heteroatom-containing alkyl group (Type B); and halogen atoms group (Type C). The derivatives of groups A and B could be derived from 2 by the cross-coupling reaction and functional group transformation. The halogenated derivatives (Type C) would be obtained from 3 by direct introduction of the halogen atoms. Although Wang et al. isolated the natural eurotiumide A (1) as a racemic form, they evaluated the antimicrobial activities of its enantiomers after separation by chiral HPLC and revealed that there was no significant difference between the enantiomers [23]. From the viewpoint of the efficiency of compound supply, we decided to make racemic compounds. 


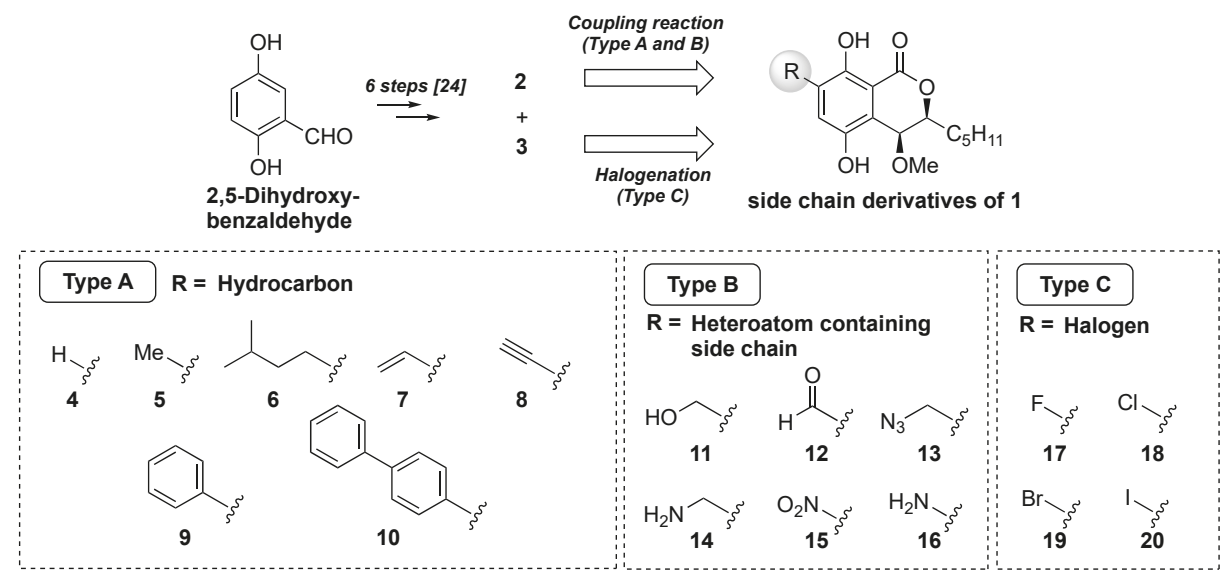

Figure 2. Synthetic plan of the side-chain derivatives of eurotiumide A (1).

First, we initiated the syntheses of the derivatives of group A (Scheme 1). The non-substituted derivative 4 was obtained from 3 by deprotection of the diMOM group with aqueous $6 \mathrm{M} \mathrm{HCl}$ in methanol at $40{ }^{\circ} \mathrm{C}$ in $79 \%$ yield. Catalytic hydrogenation of eurotiumide A (1) gave the isopentyl derivative $\mathbf{6}$ in quantitative yield. Methyl and vinyl groups were introduced by the Stille coupling reaction with 2 to afford methyl derivative $5 \mathbf{a}$ and styrene derivative 7 a in $83 \%$ and quantitative yields, respectively. Phenyl derivative $9 a$ and biphenyl derivative 10a were obtained from 2 by the Suzuki-Miyaura cross coupling reaction with the corresponding boronic acids in $75 \%$ and $77 \%$ yields, respectively. Deprotection of the diMOM group of derivatives $5 a, 7 a, 9 a$, and $\mathbf{1 0 a}$ then gave the corresponding desired products $(5,7,9$, and 10$)$. We tried to introduce the alkyne group by the Sonogashira coupling reaction; however, the desired alkyne product was obtained in only $12 \%$ yield. To improve the reaction yield, the Seyferth-Gilbert homologation using the Ohira-Bestmann reagent 21 was applied to the aldehyde derivative 12a (vide infra) and afforded the desired alkyne 8a in quantitative yield. After acidic treatment of $8 a$, the alkyne derivative 8 was obtained in $68 \%$ yield.

With type A derivatives in hand, we turned our attention to preparing type B derivatives having heteroatom-containing side chains (Scheme 2). For the introduction of an alkyl group containing heteroatoms, we chose the styrene derivative $7 \mathbf{a}$ as a starting point. Ozonolysis of the alkene moiety of 7a afforded the diMOM-protected benzaldehyde 12a in excellent yield. Acidic treatment of 12a gave the desired deprotected benzaldehyde derivative $\mathbf{1 2}$ in $77 \%$. On the other hand, reduction of the aldehyde moiety of 12a with sodium borohydride to give the benzyl alcohol 11a and the deprotection furnished the hydroxymethyl derivative $\mathbf{1 1}$ in moderate yield. To introduce a nitrogen group at the benzyl position of 11a, the primary alcohol moiety was converted to a mesyl group (22) and a nucleophilic substitution reaction with sodium azide afforded diMOM-protected azide 13a in good yield. Derivative 13a was treated with aqueous $6 \mathrm{M} \mathrm{HCl}$ in $\mathrm{MeOH}$ to furnish the desired dihydroxy azide derivative $\mathbf{1 3}$. We then tried to convert the azide into an amine functionality. After several attempts, we found that addition of triethylamine was crucial to keep the reaction clean and we succeeded to get 14a. Then, deprotection of the diMOM group gave the desired aminomethyl derivative $\mathbf{1 4}$. 


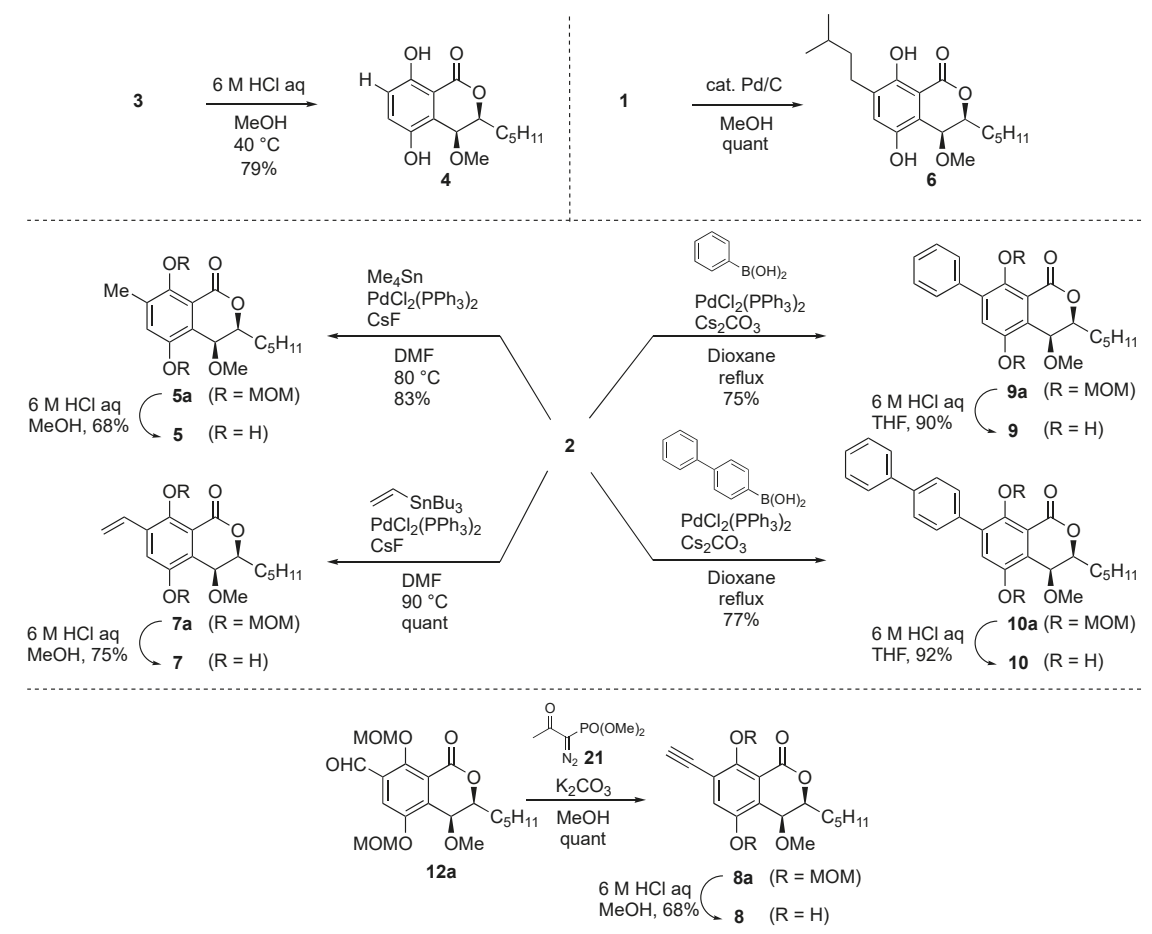

Scheme 1. Synthesis of the hydrocarbon derivatives (type A).

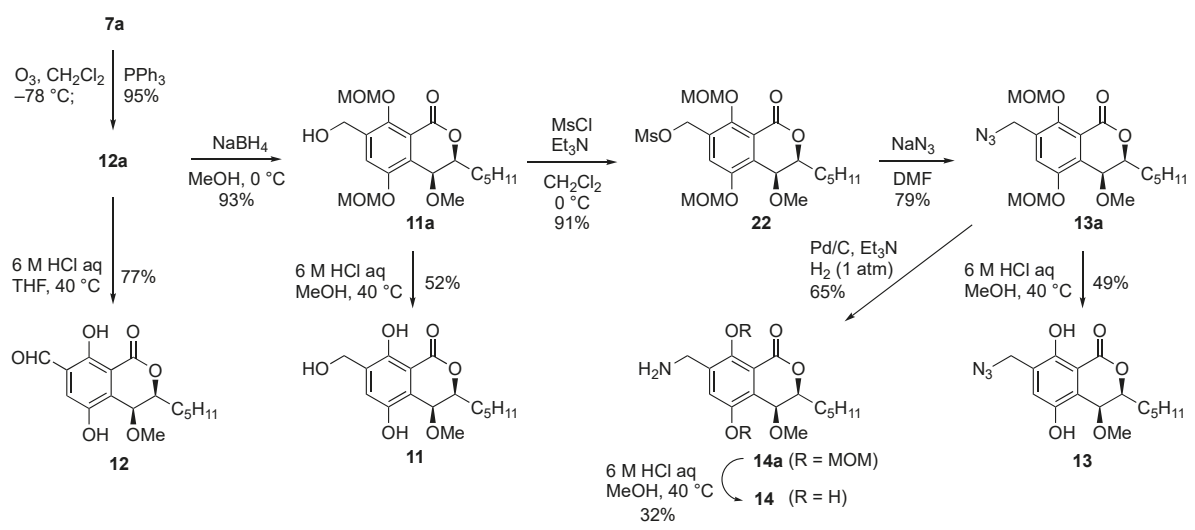

Scheme 2. Synthesis of the derivatives having heteroatom-containing side chains (type B).

Next, a nitration reaction was conducted with non-substituted derivative 3 by adding $\mathrm{HNO}_{3}$ in $\mathrm{AcOH}$ to afford monoMOM-protected nitro derivative 15a as a crude product; then it was deprotected under acidic condition to give the nitro derivative 15 (Scheme 3). After that, hydrogenation with Adam's catalyst produced the aniline derivative $\mathbf{1 6}$ from $\mathbf{1 5}$. 


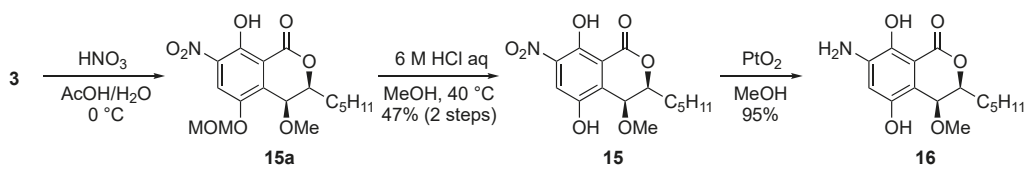

Scheme 3. Synthesis of nitro and aniline derivatives.

Finally, we tried to synthesize the halogenated derivatives (Scheme 4). Chloro and iodo groups were introduced to treat 3 with $N$-chlorosuccinimide and $N$-iodosuccinimide in DMF to afford the chloro derivative 18a and the iodo derivative 20a, respectively. The diMOM groups of 18a and 20a were then deprotected under acidic conditions to afford the desired 18 and $\mathbf{2 0}$. Bromo derivative 19 was obtained from 2 in $97 \%$ yield by acid treatment to cleave the diMOM group. However, despite several efforts to introduce fluorine to the aromatic ring from 3 , we could not get the desired fluoro derivative 17. We also tried the Sandmeyer reaction with $\mathbf{1 6}$ but did not obtain the desired 17.

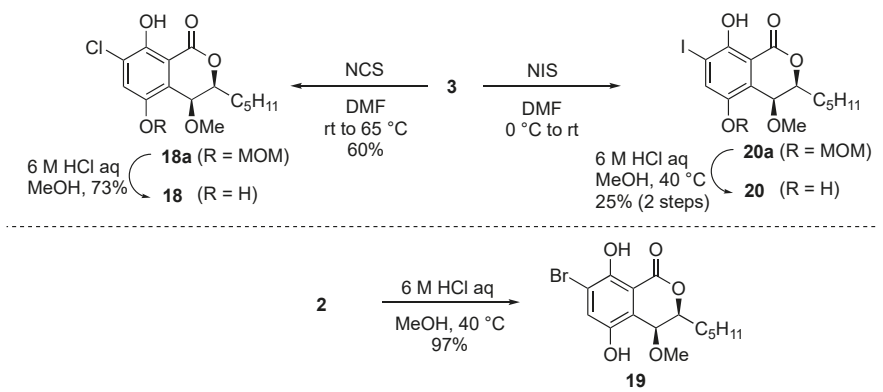

Scheme 4. Synthesis of halogenated derivatives (type C).

\subsection{Antimicrobial Evaluation of Synthesized Derivatives}

After the initially set derivatives of eurotiumide A were synthesized, the first antimicrobial activity screening was conducted against the Gram-positive MSSA and MRSA as well as the Gram-negative $P$. gingivalis in $10 \mu \mathrm{M}$ solutions of the synthesized derivatives to narrow down the promising antimicrobial candidates. The results are depicted in Figure 3. (+/-)-Eurotiumide A (1) exhibited mild antimicrobial activity against MSSA at this concentration (Figure 3a). While most of the derivatives did not show antimicrobial activity against this strain, the isopentyl derivative 6 and the iodo derivative $\mathbf{2 0}$ exhibited more potent antimicrobial activity than $\mathbf{1}$. Next, we tested the same screening against MRSA (Figure 3b). Most of the derivatives that displayed good activity against MSSA showed no antimicrobial activity against MRSA. Even natural product $\mathbf{1}$ and the iodo derivative $\mathbf{2 0}$ also did not show good antimicrobial activity against MRSA. Surprisingly, only the isopentyl derivative $\mathbf{6}$, which was a reduced derivative of $\mathbf{1}$, was found to have good antimicrobial activity against MRSA. We also conducted antimicrobial screening against $P$. gingivalis (Figure 3c). Unlike the case with S. aureus, many derivatives, specifically eurotiumide A (1), isopentyl derivative 6 , vinyl derivative 7 , aniline derivative $\mathbf{1 6}$, and three halogenated derivatives $(\mathbf{1 8}, \mathbf{1 9}, \mathbf{2 0})$, were effective against $P$. gingivalis. 
(a) methicillin-susceptible $S$. aureus

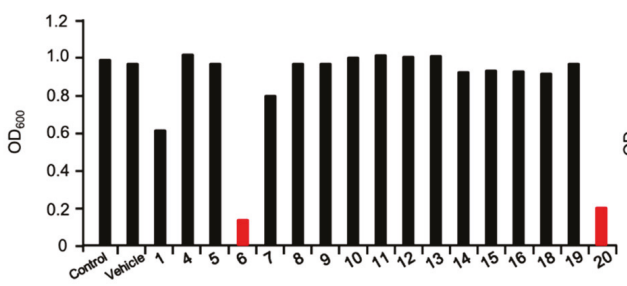

(b) methicillin-resistant $S$. aureus

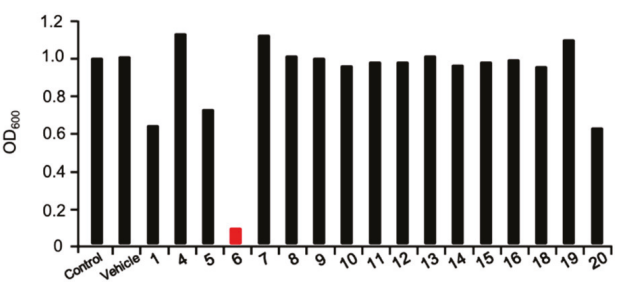

(c) P. gingivalis

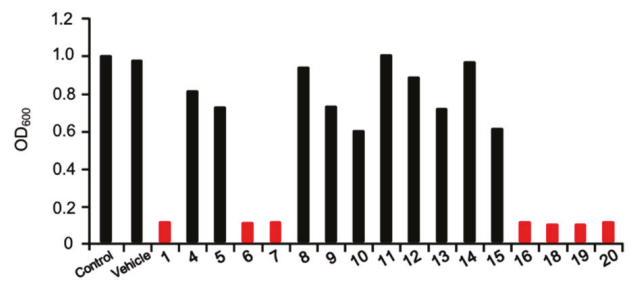

Figure 3. Initial screening of antimicrobial activity against (a) methicillin-susceptible S. aureus, (b) methicillin-resistant $S$. aureus, and (c) $P$. gingivalis. The terminal concentration was $10 \mu \mathrm{M}$.

Since we acquired promising agents against all three strains, we determined the $\mathrm{IC}_{50}$ values of these candidates (Table 1). The $\mathrm{IC}_{50}$ values of the isopentyl derivative $\mathbf{6}$ and the iodo derivative 20 against MSSA were $5.6 \mu \mathrm{M}(2.0 \mu \mathrm{g} / \mathrm{mL})$ and $9.0 \mu \mathrm{M}(3.7 \mu \mathrm{g} / \mathrm{mL})$, respectively. Moreover, the $\mathrm{IC}_{50}$ value of 6 against MRSA was $4.3 \mu \mathrm{M}(1.5 \mu \mathrm{g} / \mathrm{mL})$, which is the same level of activity against MSSA. The IC 50 values of these seven candidates $(\mathbf{1}, \mathbf{6}, \mathbf{7}, \mathbf{1 6}, \mathbf{1 8}, \mathbf{1 9}$, and 20) against $P$. gingivalis ranged from 2.0 to $7.0 \mu \mathrm{M}$. We also checked the cytotoxicity of three compounds $(\mathbf{1}, \mathbf{6}$, and $\mathbf{2 0})$ against the A549 cell line, and these three compounds were non-toxic in $10 \mu \mathrm{M}$.

Table 1. The $\mathrm{IC}_{50}$ values $(\mu \mathrm{M})$ of the selected side chain derivatives against methicillin-susceptible $S$. aureus (MSSA), methicillin-resistant S. aureus (MRSA), and P. gingivalis. Vancomycin (VCM) was used as a positive control against MSSA and MRSA. Cefcapene pivoxyl (CFPN-PI) was used as a positive control against $P$. gingivalis.

\begin{tabular}{cccccccccc}
\hline Strains & $\mathbf{1}$ & $\mathbf{6}$ & $\mathbf{7}$ & $\mathbf{1 6}$ & $\mathbf{1 8}$ & $\mathbf{1 9}$ & $\mathbf{2 0}$ & VCM & CFPN-PI \\
\hline $\begin{array}{c}\text { Methicillin-susceptible } \\
\text { S. aureus (MSSA) }\end{array}$ & - & 5.6 & - & - & - & - & 9.0 & 1.3 & - \\
\hline $\begin{array}{c}\text { Methicillin-resistant } \\
\text { S. aureus (MRSA) }\end{array}$ & - & 4.3 & - & - & - & - & - & 1.5 & - \\
\hline P. gingivalis & 3.6 & 2.0 & 3.5 & 6.7 & 6.4 & 7.0 & 3.5 & - & 0.03 \\
\hline
\end{tabular}

In this study, we discovered that the isopentyl derivative 6, which is a one-point modified compound of natural product $\mathbf{1}$, and the iodo derivative $\mathbf{2 0}$ have superior antimicrobial activity to $\mathbf{1}$ against MSSA and P. gingivalis. Although 20 did not exhibit good efficacy against MRSA, 6 was found to maintain antimicrobial activity against these three strains, including MRSA. These results indicate that S. aureus is sensitive to changes in the side chain of the aromatic ring and that MRSA can distinguish the subtle difference between prenyl and isopentyl moieties. Moreover, the weak antimicrobial activity of 1 against MRSA suggests a binding affinity between $\mathbf{1}$ and the penicillin binding protein 2' [26], which is the main resistance mechanism of MRSA against antibiotics. The inhibition of cell wall synthesis seems to be the mode of action of $\mathbf{1}$, although a more detailed study is needed to clarify the mode of action of $\mathbf{6}$ and 20. On the other hand, we found that several compounds having alkyl and halogenated side chains well suppressed the increase in $P$. gingivalis. 


\section{Materials and Methods}

\subsection{Preparation of Eurotiumide A Derivatives.}

\subsubsection{General Procedure}

All the reactions were carried out in a round-bottomed flask with an appropriate number of necks and side arms connected to a three-way stopcock and/or a rubber septum cap under an argon atmosphere. All vessels were first evacuated by rotary pump and then flushed with argon prior to use. Solutions and solvents were introduced by hypodermic syringe through a rubber septum. During the reaction, the vessel was kept under a positive pressure of argon. Dry THF was freshly prepared by distillation from benzophenone ketyl before use. Anhydrous $\mathrm{CH}_{2} \mathrm{Cl}_{2}, \mathrm{DMF}$, ethanol, $\mathrm{MeCN}$, methanol, pyridine, and toluene were purchased from Kanto Chemical Co. Inc. Infrared (IR) spectra were recorded on a JASCO FT/IR-4100 spectrophotometer using a $5 \mathrm{~mm} \mathrm{KBr}$ plate. Wavelengths of maximum absorbance are quoted in $\mathrm{cm}^{-1}$. 1H-NMR spectra were recorded on a JEOL ECA-400 (400 MHz), Bruker AV-400N (400 MHz), and Bruker AV-500 (500 MHz) in $\mathrm{CDCl}_{3}$. Chemical shifts are reported in parts per million (ppm), and signals are expressed as singlet (s), doublet (d), triplet $(\mathrm{t})$, multiplet (m), broad (br), and overlapped. 13C-NMR spectra were recorded on a JEOL ECA-400 $(100 \mathrm{MHz})$, Bruker AV-400N (100 MHz), and Bruker AV-500 (125 MHz) in $\mathrm{CDCl}_{3}$. Chemical shifts are reported in parts per million (ppm) (see Supplementary Materials). High resolution mass (HRMS) spectra were recorded on a Thermo Scientific Exactive. All melting points were measured with a Yanaco MP-500D. Analytical thin layer chromatography (TLC) was performed using $0.25 \mathrm{~mm}$ E. Merck Silica gel (60F-254) plates. Reaction components were visualized phosphomolybdic acid or ninhydrin or $p$-anisaldehyde in $10 \%$ sulfuric acid in ethanol. Kanto Chem. Co. Silica Gel 60N (particle size 0.040-0.050 $\mathrm{mm}$ ) was used for column chromatography.

\subsubsection{Synthesis of $(3 S, 4 S)$-5,8-dihydroxy-4-methoxy-3-pentylisochroman-1-one (4)}

To a solution of bromo compound $3(10.0 \mathrm{mg}, 30.8 \mu \mathrm{mol})$ in $\mathrm{MeOH}(2.3 \mathrm{~mL})$ was added $6 \mathrm{M}$ aqueous $\mathrm{HCl}(0.77 \mathrm{~mL})$ at $0{ }^{\circ} \mathrm{C}$. After stirring for $30 \mathrm{~min}$ at $40{ }^{\circ} \mathrm{C}$, the reaction was quenched by adding saturated aqueous $\mathrm{NaHCO}_{3}$ at $0{ }^{\circ} \mathrm{C}$. The mixture was extracted with EtOAc $(\times 3)$ and the combined organic layers were washed with brine, dried over $\mathrm{Na}_{2} \mathrm{SO}_{4}$, filtered, and concentrated under reduced pressure. The residue was purified by preparative thin layer chromatography (PTLC) (EtOAc: $n$-hexane $=3: 7)$ to give non-substituted derivative $4(6.8 \mathrm{mg}, 79 \%)$ as a white solid. m.p. $120-121{ }^{\circ} \mathrm{C} ; 1 \mathrm{H}-\mathrm{NMR}$ $\left(400 \mathrm{MHz} \mathrm{CDCl}_{3}\right) \delta 10.62(1 \mathrm{H}, \mathrm{s}), 7.06(1 \mathrm{H}, \mathrm{d}, J=9.0 \mathrm{~Hz}), 6.91(1 \mathrm{H}, \mathrm{d}, J=9.0 \mathrm{~Hz}), 5.89(1 \mathrm{H}, \mathrm{br}-\mathrm{s}), 4.77$ $(1 \mathrm{H}, \mathrm{d}, J=2.7 \mathrm{~Hz}), 4.50(1 \mathrm{H}, \mathrm{ddd}, J=2.7,5.4,8.3 \mathrm{~Hz}), 3.40(3 \mathrm{H}, \mathrm{s}), 1.95(1 \mathrm{H}, \mathrm{m}), 1.85(1 \mathrm{H}, \mathrm{m}), 1.70-1.50$ (1H, overlapped), $1.46(1 \mathrm{H}, \mathrm{m}), 1.40-1.25$ (4H, overlapped), $0.91(3 \mathrm{H}, \mathrm{t}, J=6.8 \mathrm{~Hz}) ; 13 \mathrm{C}-\mathrm{NMR}(100 \mathrm{MHz}$, $\left.\mathrm{CDCl}_{3}\right) \delta 169.0,156.2,145.7,125.1,121.7,118.8,107.6,81.4,69.8,56.8,31.6,29.8,24.9,22.5,14.0 . ; \mathrm{IR}(\mathrm{KBr})$ $3219,2955,2924,2860,1661,1586,1471,1293,1204,905 \mathrm{~cm}^{-1}$; HRMS (ESI) $\mathrm{m} / z(\mathrm{M}+\mathrm{Na})^{+}$calculated for $\left(\mathrm{C}_{15} \mathrm{H}_{20} \mathrm{O}_{5} \mathrm{Na}\right)^{+}$303.1208, found 303.1200.

\subsubsection{Synthesis of $(3 S, 4 S)-5,8$-dihydroxy-7-isopentyl-4-methoxy-3-pentylisochroman-1-one (6)}

To a solution of eurotiumide $\mathrm{A}(\mathbf{1})(1.6 \mathrm{mg}, 4.6 \mu \mathrm{mol})$ in $\mathrm{MeOH}(0.23 \mathrm{~mL})$ was added $\mathrm{Pd} / \mathrm{C}(1.6 \mathrm{mg}$, $100 \mathrm{w} / \mathrm{w} \%$ ) at room temperature. After stirring for $1.5 \mathrm{~h}$ under hydrogen atmosphere (balloon), the reaction mixture was passed through Celite and the organic solvent was removed under reduced pressure. The residue was purified with flash column chromatography (EtOAc: $n$-hexane $=2: 3$ ) to give isopentyl derivative $6(1.4 \mathrm{mg}, 88 \%)$ as a white wax. $1 \mathrm{H}-\mathrm{NMR}\left(500 \mathrm{MHz}, \mathrm{CDCl}_{3}\right) \delta 10.91(1 \mathrm{H}, \mathrm{s}), 6.93$ $(1 \mathrm{H}, \mathrm{s}), 5.62(1 \mathrm{H}, \mathrm{br}-\mathrm{s}), 4.74(1 \mathrm{H}, \mathrm{d}, J=2.5 \mathrm{~Hz}), 4.48(1 \mathrm{H}, \mathrm{ddd}, J=2.6,5.4,8.6 \mathrm{~Hz}), 3.38(3 \mathrm{H}, \mathrm{s}), 2.62$ $(2 \mathrm{H}, \mathrm{m}), 1.95(1 \mathrm{H}, \mathrm{m}), 1.85(1 \mathrm{H}, \mathrm{m}), 1.65-1.50$ (2H, overlapped), 1.50-1.40 (3H, overlapped), 1.40-1.30 (4H, overlapped), $0.95(6 \mathrm{H}, \mathrm{d}, J=6.3 \mathrm{~Hz}), 0.90(3 \mathrm{H}, J=6.9 \mathrm{~Hz}) ; 13 \mathrm{C}-\mathrm{NMR}\left(125 \mathrm{MHz}, \mathrm{CDCl}_{3}\right) \delta 169.4$, 154.7, 145.0, 133.6, 124.8, 118.6, 106.8, 81.4, 69.9, 56.6, 38.4, 31.6, 29.8, 29.7, 27.9, 27.5, 14.9, 22.5, 14.0.; 
IR (KBr) 3290, 2956, 2927, 2870, 1761, 1445, 1171, $807 \mathrm{~cm}^{-1}$; HRMS (ESI) $m / z(\mathrm{M}+\mathrm{H})^{+}$calculated for $\left(\mathrm{C}_{20} \mathrm{H}_{31} \mathrm{O}_{5}\right)^{+}$351.2171, found 351.2177.

3.1.4. (3S,4S)-4-methoxy-5,8-bis(methoxymethoxy)-7-methyl-3-pentylisochroman-1-one (5a)

To a solution of bromo compound $3(40.0 \mathrm{mg}, 89.4 \mu \mathrm{mol})$ and CsF $(16.3 \mathrm{mg}, 107 \mu \mathrm{mol})$ in degassed DMF $(0.45 \mathrm{~mL})$ were added $\mathrm{Me}_{4} \mathrm{Sn}(15 \mu \mathrm{L}, 107 \mu \mathrm{mol})$ and $\mathrm{PdCl}_{2}\left(\mathrm{PPh}_{3}\right)_{2}(6.3 \mathrm{mg}, 8.94 \mu \mathrm{mol})$ at room temperature. After stirring for $50 \mathrm{~min}$ at $80^{\circ} \mathrm{C}$, the reaction was quenched by adding water. The mixture was extracted with EtOAc $(\times 3)$ and the combined organic layers were washed with brine, dried over $\mathrm{Na}_{2} \mathrm{SO}_{4}$, filtered, and concentrated under reduced pressure. The residue was purified with flash column chromatography (EtOAc: $n$-hexane = 3:7) to give diMOM-protected methyl derivative 5a $(28.5 \mathrm{mg}, 83 \%)$ as a yellow amorphous. 1H-NMR (400 MHz, CDCl 3 ) $\delta 7.255(1 \mathrm{H}, \mathrm{s}), 5.21(2 \mathrm{H}, \mathrm{s}), 5.10$ $(1 \mathrm{H}, \mathrm{d}, J=6.8 \mathrm{~Hz}), 5.07(1 \mathrm{H}, \mathrm{d}, J=6.8 \mathrm{~Hz}), 4.59(1 \mathrm{H}, \mathrm{d}, J=1.5 \mathrm{~Hz}), 4.26(1 \mathrm{H}, \mathrm{ddd}, J=1.5,5.9,7.5 \mathrm{~Hz})$, $3.60(3 \mathrm{H}, \mathrm{s}), 3.50(3 \mathrm{H}, \mathrm{s}), 3.30(3 \mathrm{H}, \mathrm{s}), 2.39(3 \mathrm{H}, \mathrm{s}), 2.02(1 \mathrm{H}, \mathrm{m}), 1.81(1 \mathrm{H}, \mathrm{m}), 1.70-1.50(1 \mathrm{H}$, overlapped), $1.43(1 \mathrm{H}, \mathrm{m}), 1.40-1.25$ (4H, overlapped), $0.91(3 \mathrm{H}, \mathrm{t}, J=6.8 \mathrm{~Hz}) ; 13 \mathrm{C}-\mathrm{NMR}\left(125 \mathrm{MHz}, \mathrm{CDCl}_{3}\right) \delta 162.4$, 152.3, 149.8, 135.7, 126.3, 121.3, 118.7, 101.5, 95.0, 80.9, 68.2, 57.5, 56.7, 56.4, 31.6, 30.6, 24.9, 22.6, 17.6, 14.0.; IR (KBr) 2958, 2927, 2858, 2828, 1728, 1478, $1153 \mathrm{~cm}^{-1}$; HRMS (ESI) $m / z(\mathrm{M}+\mathrm{H})^{+}$calculated for $\left(\mathrm{C}_{20} \mathrm{H}_{31} \mathrm{O}_{7}\right)^{+}$383.2070, found 383.2069.

\subsection{5. (3S,4S)-5,8-dihydroxy-4-methoxy-7-methyl-3-pentylisochroman-1-one (5)}

To a solution of diMOM-protected methyl derivative $5 \mathrm{a}(10.0 \mathrm{mg}, 26.0 \mu \mathrm{mol})$ in $\mathrm{MeOH}(2.0 \mathrm{~mL})$ was added $6 \mathrm{M}$ aqueous $\mathrm{HCl}(0.65 \mathrm{~mL})$ at $0{ }^{\circ} \mathrm{C}$. After stirring for $1 \mathrm{~h}$ at $40{ }^{\circ} \mathrm{C}$, the reaction was quenched by adding saturated aqueous $\mathrm{NaHCO}_{3}$. The mixture was extracted with EtOAc $(\times 3)$ and the combined organic layers were washed with brine, dried over $\mathrm{Na}_{2} \mathrm{SO}_{4}$, filtered, and concentrated under reduced pressure. The residue was purified with PTLC (EtOAc: $n$-hexane $=3: 7$ ) to give methyl derivative 5 $(5.2 \mathrm{mg}, 68 \%)$ as a yellow solid. m.p. $113^{\circ} \mathrm{C}$; $1 \mathrm{H}-\mathrm{NMR}\left(400 \mathrm{MHz}, \mathrm{CDCl}_{3}\right) \delta 10.89(1 \mathrm{H}, \mathrm{s}), 6.93(1 \mathrm{H}, \mathrm{s})$, $5.59(1 \mathrm{H}, \mathrm{br}-\mathrm{s}), 4.75(1 \mathrm{H}, \mathrm{d}, J=2.7 \mathrm{~Hz}), 4.48(1 \mathrm{H}, \mathrm{ddd}, J=2.7,5.4,8,3 \mathrm{~Hz}), 3.37(3 \mathrm{H}, \mathrm{s}), 2.25(3 \mathrm{H}, \mathrm{s}), 1.93$ $(1 \mathrm{H}, \mathrm{m}), 1.84(1 \mathrm{H}, \mathrm{m}), 1.70-1.50(1 \mathrm{H}$, overlapped $), 1.45(1 \mathrm{H}, \mathrm{m}), 1.40-1.25(4 \mathrm{H}$, overlapped $), 0.91(3 \mathrm{H}$, $\mathrm{t}, J=6.6 \mathrm{~Hz}) ; 13 \mathrm{C}-\mathrm{NMR}\left(125 \mathrm{MHz}, \mathrm{CDCl}_{3}\right) \delta 169.4,154.9,144.9,128.7,125.8,118.6,106.6,81.4,69.8$, 56.5, 31.6, 29.8, 24.9, 22.5, 15.8, 14.0.; IR (KBr) 3340, 2957, 2928, 2859, 1682, 1654, 1604, 1296, $1172 \mathrm{~cm}^{-1}$; HRMS (ESI) $m / z(\mathrm{M}+\mathrm{Na})^{+}$calculated for $\left(\mathrm{C}_{16} \mathrm{H}_{22} \mathrm{O}_{5} \mathrm{Na}\right)^{+} 317.1365$, found 317.1350.

\subsection{6. (3S,4S)-4-methoxy-5,8-bis(methoxymethoxy)-3-pentyl-7-vinylisochroman-1-one (7a)}

To a solution of bromo compound $3(200 \mathrm{mg}, 0.447 \mathrm{mmol})$ and CsF $(135.8 \mathrm{mg}, 0.894 \mathrm{mmol})$ in degassed DMF (2.2 mL) were added tributylvinyltin $(0.26 \mathrm{~mL}, 0.894 \mathrm{mmol})$ and $\mathrm{PdCl}_{2}\left(\mathrm{PPh}_{3}\right)_{2}(62.8 \mathrm{mg}$, $89.0 \mu \mathrm{mol})$ at room temperature. After stirring for $1 \mathrm{~h}$ at $80^{\circ} \mathrm{C}$, the reaction was quenched by adding water. The mixture was extracted with EtOAc $(\times 3)$ and the combined organic layers were washed with brine, dried over $\mathrm{Na}_{2} \mathrm{SO}_{4}$, filtered, and concentrated under reduced pressure. The residue was purified with flash column chromatography (EtOAc: $n$-hexane $=3: 7$ ) to give diMOM-protected vinyl derivative 7a (185.1 mg, quant) as a yellow solid. m.p. 63-64 ${ }^{\circ} \mathrm{C} ; 1 \mathrm{H}-\mathrm{NMR}\left(500 \mathrm{MHz}, \mathrm{CDCl}_{3}\right) \delta 7.56$ $(1 \mathrm{H}, \mathrm{s}), 7.14(1 \mathrm{H}, \mathrm{dd}, J=11.1,17.7 \mathrm{~Hz}), 5.76(1 \mathrm{H}, \mathrm{d}, J=17.7 \mathrm{~Hz}), 5.40(1 \mathrm{H}, \mathrm{d}, J=11.1 \mathrm{~Hz}), 5.24(2 \mathrm{H}$, s), $5.08(1 \mathrm{H}, \mathrm{d}, J=6.3 \mathrm{~Hz}), 5.05(1 \mathrm{H}, \mathrm{d}, J=6.3 \mathrm{~Hz}), 4.60(1 \mathrm{H}, \mathrm{d}, J=1.3 \mathrm{~Hz}), 4.26(1 \mathrm{H}, \mathrm{ddd}, J=1.3,5.8$, $7.4 \mathrm{~Hz}), 3.58(3 \mathrm{H}, \mathrm{s}), 3.50(3 \mathrm{H}, \mathrm{s}), 3.31(3 \mathrm{H}, \mathrm{s}), 2.03(1 \mathrm{H}, \mathrm{m}), 1.81(1 \mathrm{H}, \mathrm{m}), 1.56(1 \mathrm{H}, \mathrm{m}), 1.43(1 \mathrm{H}, \mathrm{m})$, 1.40-1.25 (4H, overlapped), $0.90(3 \mathrm{H}, \mathrm{t}, J=6.9 \mathrm{~Hz})$; 13C-NMR (125 MHz, $\left.\mathrm{CDCl}_{3}\right) \delta 162.0,150.7,150.2$, $134.9,131.3,128.5,119.7,116.7,116.0,101.5,95.2,80.8,68.3,57.9,56.8,56.4,31.6,30.6,24.9,22.5,14.0$.; IR (KBr) 2953, 2931, 2861, 2829, 1730, 1471, 1426, 1155, $929 \mathrm{~cm}^{-1}$; HRMS (ESI) $\mathrm{m} / \mathrm{z}(\mathrm{M}+\mathrm{H})^{+}$calculated for $\left(\mathrm{C}_{21} \mathrm{H}_{31} \mathrm{O}_{7}\right)^{+}$395.2070, found 395.2078.

3.1.7. (3S,4S)-5,8-dihydroxy-4-methoxy-3-pentyl-7-vinylisochroman-1-one (7)

To a solution of diMOM-protected methyl derivative $7 \mathrm{a}(13.7 \mathrm{mg}, 34.7 \mu \mathrm{mol})$ in $\mathrm{MeOH}(2.6 \mathrm{~mL})$ was added $6 \mathrm{M}$ aqueous $\mathrm{HCl}(0.87 \mathrm{~mL})$ at $0{ }^{\circ} \mathrm{C}$. After stirring for $3 \mathrm{~h}$ at $40^{\circ} \mathrm{C}$, the reaction was quenched 
by adding saturated aqueous $\mathrm{NaHCO}_{3}$. The mixture was extracted with EtOAc $(\times 3)$ and the combined organic layers were washed with brine, dried over $\mathrm{Na}_{2} \mathrm{SO}_{4}$, filtered, and concentrated under reduced pressure. The residue was purified with PTLC (EtOAc: $n$-hexane $=3: 7$ ) to give vinyl derivative 7 $(8.5 \mathrm{mg}, 75 \%)$ as a yellow wax. $1 \mathrm{H}-\mathrm{NMR}\left(500 \mathrm{MHz}, \mathrm{CDCl}_{3}\right) \delta 11.10(1 \mathrm{H}, \mathrm{s}), 7.23(1 \mathrm{H}, \mathrm{s}), 7.01(1 \mathrm{H}, \mathrm{dd}$, $J=11.4,17.7 \mathrm{~Hz}), 5.82(1 \mathrm{H}, \mathrm{br}-\mathrm{s}), 5.80(1 \mathrm{H}, \mathrm{d}, J=18.0 \mathrm{~Hz}), 5.37(1 \mathrm{H}, \mathrm{d}, J=11.0 \mathrm{~Hz}), 4.77(1 \mathrm{H}, \mathrm{br}-\mathrm{s}), 4.50$ (1H, br-s), $3.40(3 \mathrm{H}, \mathrm{s}), 1.95(1 \mathrm{H}, \mathrm{m}), 1.85(1 \mathrm{H}, \mathrm{m}), 1.58(1 \mathrm{H}, \mathrm{m}), 1.45(1 \mathrm{H}, \mathrm{m}), 1.40-1.25$ (4H, overlapped), 0.90 (3H, br-s); 13C-NMR (125 MHz, $\left.\mathrm{CDCl}_{3}\right) \delta 169.3,153.9,145.4,129.8,128.0,121.4,120.9,116.5,107.7$, 81.5, 69.7, 56.8, 31.6, 29.8, 24.9, 22.5, 14.0.; IR (KBr) 3311, 2956, 2930, 2859, 1659, 1438, $1171 \mathrm{~cm}^{-1}$; HRMS (ESI) $m / z(\mathrm{M}+\mathrm{Na})^{+}$calculated for $\left(\mathrm{C}_{17} \mathrm{H}_{22} \mathrm{O}_{5} \mathrm{Na}\right)^{+} 329.1365$, found 329.1368 .

\subsection{8. (3S,4S)-4-methoxy-5,8-bis(methoxymethoxy)-3-pentyl-7-phenylisochroman-1-one (9a)}

Bromo compound $3(10.0 \mathrm{mg}, 22.4 \mu \mathrm{mol}), \mathrm{Cs}_{2} \mathrm{CO}_{3}(21.9 \mathrm{mg}, 67.1 \mu \mathrm{mol})$, phenylboronic acid $(5.5 \mathrm{mg}, 44.7 \mu \mathrm{M})$, and $\mathrm{PdCl}_{2}\left(\mathrm{PPh}_{3}\right)_{2}(3.1 \mathrm{mg}, 44.7 \mu \mathrm{mol})$ were dissolved in degassed dioxane $(0.22 \mathrm{~mL})$ at room temperature. After stirring for $1 \mathrm{~h}$ under reflux condition, the reaction was quenched by adding saturated aqueous $\mathrm{NH}_{4} \mathrm{Cl}$. The mixture was extracted with EtOAc $(\times 3)$ and the combined organic layers were washed with brine, dried over $\mathrm{Na}_{2} \mathrm{SO}_{4}$, filtered, and concentrated under reduced pressure. The residue was purified with flash column chromatography (EtOAc: $n$-hexane $=3: 7$ ) to give diMOM-protected phenyl derivative 9a $(7.4 \mathrm{mg}, 75 \%)$ as a white wax. $1 \mathrm{H}-\mathrm{NMR}\left(500 \mathrm{MHz}, \mathrm{CDCl}_{3}\right) \delta$ $7.55(1 \mathrm{H}, \mathrm{d}, J=7.6 \mathrm{~Hz}), 7.50-7.38$ (3H, overlapped), $7.36(1 \mathrm{H}, \mathrm{dd}, J=7.3 \mathrm{~Hz}), 5.25(2 \mathrm{H}, \mathrm{s}), 4.80(2 \mathrm{H}, \mathrm{s})$, $4.66(1 \mathrm{H}, \mathrm{s}), 4.33(1 \mathrm{H}, \mathrm{t}, J=7.0 \mathrm{~Hz}), 3.50(3 \mathrm{H}, \mathrm{s}), 3.37(3 \mathrm{H}, \mathrm{s}), 2.92(3 \mathrm{H}, \mathrm{s}), 2.06(1 \mathrm{H}, \mathrm{m}), 1.85(1 \mathrm{H}, \mathrm{m})$, 1.70-1.50 (1H, overlapped), 1.50-1.25 (5H, overlapped), 0.92 (3H, br-s); 13C-NMR (125 MHz, $\left.\mathrm{CDCl}_{3}\right) \delta$ $162.1,150.5,150.0,139.5,137.9,129.8,128.3,128.1,127.7,121.0,119.9,101.0,95.1,80.8,68.3,57.1,56.4$, 31.6, 30.6, 24.9, 22.5, 14.0.; IR (KBr) 2956, 2927, 2859, 2828, 1728, 1467, 1152, 1008, $932 \mathrm{~cm}^{-1}$; HRMS (ESI) $m / z(\mathrm{M}+\mathrm{Na})^{+}$calculated for $\left(\mathrm{C}_{25} \mathrm{H}_{32} \mathrm{O}_{7} \mathrm{Na}\right)^{+} 467.2046$, found 467.2043.

\subsection{9. (3S,4S)-5,8-dihydroxy-4-methoxy-3-pentyl-7-phenylisochroman-1-one (9)}

To a solution of diMOM-protected methyl derivative 9 a $(7.4 \mathrm{mg}, 16.8 \mu \mathrm{mol})$ in THF $(1.0 \mathrm{~mL})$ was added $6 \mathrm{M}$ aqueous $\mathrm{HCl}(0.50 \mathrm{~mL})$ at $0{ }^{\circ} \mathrm{C}$. After stirring for $6 \mathrm{~h}$ at room temperature, the reaction was quenched by adding saturated aqueous $\mathrm{NaHCO}_{3}$. The mixture was extracted with EtOAc $(\times 3)$ and the combined organic layers were washed with brine, dried over $\mathrm{Na}_{2} \mathrm{SO}_{4}$, filtered, and concentrated under reduced pressure. The residue was purified with PTLC (EtOAc: $n$-hexane $=3: 7$ ) to give phenyl derivative $9(6.0 \mathrm{mg}, 90 \%)$ as a yellow solid. m.p. $173-174{ }^{\circ} \mathrm{C} ; 1 \mathrm{H}-\mathrm{NMR}\left(400 \mathrm{MHz}, \mathrm{CDCl}_{3}\right) \delta 11.21$ $(1 \mathrm{H}, \mathrm{s}), 7.58(2 \mathrm{H}, \mathrm{d}, J=7.3 \mathrm{~Hz}), 7.44(2 \mathrm{H}, \mathrm{t}, J=7.3 \mathrm{~Hz}), 7.38(1 \mathrm{H}, \mathrm{d}, J=7.6 \mathrm{~Hz}), 7.13(1 \mathrm{H}, \mathrm{s}), 5.76(1 \mathrm{H}$, br-s), $4.82(1 \mathrm{H}, \mathrm{d}, J=2.7 \mathrm{~Hz}), 4.55(1 \mathrm{H}, \mathrm{ddd}, J=2.7,5.1,8.3 \mathrm{~Hz}), 3.44(3 \mathrm{H}, \mathrm{s}), 1.98(1 \mathrm{H}, \mathrm{m}), 1.89(1 \mathrm{H}, \mathrm{m})$, 1.70-1.40 (2H, overlapped), 1.40-1.25 (4H, overlapped), $0.92(3 \mathrm{H}, \mathrm{t}, J=6.8 \mathrm{~Hz}) ; 13 \mathrm{C}-\mathrm{NMR}(125 \mathrm{MHz}$, $\left.\mathrm{CDCl}_{3}\right) \delta 169.5,153.7,145.4,136.2,131.8,129.2,128.3,127.9,125.5,121.1,107.8,81.6,69.6,56.9,31.6,29.8$, 24.9, 22.5, 14.0.; IR (KBr) 3307, 2955, 2928, 2859, 1650, 1425, 1295, $1194 \mathrm{~cm}^{-1}$; HRMS (ESI) $m / z(\mathrm{M}+\mathrm{H})^{+}$ calculated for $\left(\mathrm{C}_{21} \mathrm{H}_{25} \mathrm{O}_{5}\right)^{+} 357.1702$, found 357.1707 .

3.1.10. (3S,4S)-7-([1,1'-biphenyl]-4-yl)-4-methoxy-5,8-bis(methoxymethoxy)-3-pentylisochroman-1one (10a)

Bromo compound 3 (20.0 mg, $44.7 \mu \mathrm{mol}), \mathrm{Cs}_{2} \mathrm{CO}_{3}(21.9 \mathrm{mg}, 67.1 \mu \mathrm{mol})$, 4-biphenylboronic acid $(5.5 \mathrm{mg}, 44.7 \mu \mathrm{mol})$, and $\mathrm{PdCl}_{2}\left(\mathrm{PPh}_{3}\right)_{2}(3.2 \mathrm{mg}, 4.47 \mu \mathrm{mol})$ were dissolved in degassed dioxane $(0.23 \mathrm{~mL})$ at room temperature. After stirring for $1 \mathrm{~h}$ under reflux condition, the reaction was quenched by adding saturated aqueous $\mathrm{NH}_{4} \mathrm{Cl}$. The mixture was extracted with EtOAc $(\times 3)$ and the combined organic layers were washed with brine, dried over $\mathrm{Na}_{2} \mathrm{SO}_{4}$, filtered, and concentrated under reduced pressure. The residue was purified with PTLC (EtOAc: $n$-hexane $=3: 7$ ) to give diMOM-protected biphenyl derivative $10 \mathrm{a}(18.0 \mathrm{mg}, 88 \%)$ as a white solid. $1 \mathrm{H}-\mathrm{NMR}\left(500 \mathrm{MHz}, \mathrm{CDCl}_{3}\right) \delta 7.74-7.60(6 \mathrm{H}$, overlapped), 7.53-7.40 (3H, overlapped), $7.38(1 \mathrm{H}, \mathrm{t}, J=7.3 \mathrm{~Hz}), 5.28(2 \mathrm{H}, \mathrm{s}), 4.85(1 \mathrm{H}, \mathrm{d}, J=7.0 \mathrm{~Hz})$, $4.84(1 \mathrm{H}, \mathrm{d}, J=7.0 \mathrm{~Hz}), 4.68(1 \mathrm{H}, \mathrm{d}, J=1.3 \mathrm{~Hz}), 4.35(1 \mathrm{H}, \mathrm{ddd}, J=1.3,6.0,7.6 \mathrm{~Hz}), 3.51(3 \mathrm{H}, \mathrm{s}), 3.38$ 
$(3 \mathrm{H}, \mathrm{s}), 2.99(3 \mathrm{H}, \mathrm{s}), 2.08(1 \mathrm{H}, \mathrm{m}), 1.86(1 \mathrm{H}, \mathrm{m}), 1.70-1.50(1 \mathrm{H}$, overlapped $), 1.46(1 \mathrm{H}, \mathrm{m}), 1.40-1.25(4 \mathrm{H}$, overlapped), $0.92(3 \mathrm{H}, \mathrm{t}, J=6.9 \mathrm{~Hz})$; 13C-NMR $\left(125 \mathrm{MHz}, \mathrm{CDCl}_{3}\right) \delta 162.1,150.6,150.0,140.5,140.4$, 139.1, 136.8, 130.2, 128.9, 128.1, 127.5, 127.0, 126.9, 120.9, 120.0, 101.1, 95.1, 80.8, 68.3, 57.2, 56.9, 56.4, 31.6, 30.6, 24.9, 22.5, 14.0.; IR (KBr) 2956, 2927, 2858, 2827, 1728, 1467, 1152, 1007, $931 \mathrm{~cm}^{-1}$; HRMS (ESI) $m / z(\mathrm{M}+\mathrm{H})^{+}$calculated for $\left(\mathrm{C}_{31} \mathrm{H}_{37} \mathrm{O}_{7}\right)^{+} 521.2539$, found 521.2539 .

\subsubsection{1. (3S,4S)-7-([1,1'-biphenyl]-4-yl)-5,8-dihydroxy-4-methoxy-3-pentylisochroman-1-one (10)}

To a solution of diMOM-protected biphenyl derivative 10a $(12.9 \mathrm{mg}, 24.8 \mu \mathrm{mol})$ in THF $(1.7 \mathrm{~mL})$ was added $6 \mathrm{M}$ aqueous $\mathrm{HCl}(0.83 \mathrm{~mL})$ at $0{ }^{\circ} \mathrm{C}$. After stirring for $17 \mathrm{~h}$ at room temperature, the reaction was quenched by adding saturated aqueous $\mathrm{NaHCO}_{3}$ at $0{ }^{\circ} \mathrm{C}$. The mixture was extracted with EtOAc $(\times 3)$ and the combined organic layers were washed with brine, dried over $\mathrm{Na}_{2} \mathrm{SO}_{4}$, filtered, and concentrated under reduced pressure. The residue was purified with PTLC (EtOAc: $n$-hexane $=3: 7)$ to give biphenyl derivative $10(9.9 \mathrm{mg}, 92 \%)$ as a yellow solid. m.p. $181-182{ }^{\circ} \mathrm{C} ; 1 \mathrm{H}-\mathrm{NMR}(400 \mathrm{MHz}$, $\left.\mathrm{CDCl}_{3}\right) \delta 11.28(1 \mathrm{H}, \mathrm{s}), 7.67(4 \mathrm{H}, \mathrm{s}), 7.64(2 \mathrm{H}, \mathrm{d}, J=7.3 \mathrm{~Hz}), 7.46(2 \mathrm{H}, \mathrm{t}, J=7.3 \mathrm{~Hz}), 7.37(1 \mathrm{H}, \mathrm{t}, J=7.3$ $\mathrm{Hz}), 7.19(1 \mathrm{H}, \mathrm{s}), 5.75(1 \mathrm{H}, \mathrm{br}-\mathrm{s}), 4.84(1 \mathrm{H}, \mathrm{d}, J=2.7 \mathrm{~Hz}), 4.56(1 \mathrm{H}, \mathrm{ddd}, J=2.7,5.4,8.3 \mathrm{~Hz}), 3.46(3 \mathrm{H}, \mathrm{s})$, $1.98(1 \mathrm{H}, \mathrm{m}), 1.89(1 \mathrm{H}, \mathrm{m}), 1.70-1.50(2 \mathrm{H}$, overlapped), $1.45-1.25$ (4H, overlapped), $0.92(3 \mathrm{H}, \mathrm{t}, J=6.8$ $\mathrm{Hz}) ; 13 \mathrm{C}-\mathrm{NMR}\left(125 \mathrm{MHz}, \mathrm{CDCl}_{3}\right) \delta$ 169.4, 153.8, 145.5, 140.7, 135.2, 131.4, 129.6, 128.8, 127.5,127.15, 127.07, 125.3, 121.0, 107.9, 81.5, 69.8, 56.9, 31.6, 29.8, 24.9, 22.5, 14.0.; IR (KBr) 3283, 2954, 2929, 2863, $1668,1595,1295,1220,772 \mathrm{~cm}^{-1}$; HRMS (ESI) $\mathrm{m} / \mathrm{z}(\mathrm{M}+\mathrm{Na})^{+}$calculated for $\left(\mathrm{C}_{27} \mathrm{H}_{28} \mathrm{O}_{5} \mathrm{Na}\right)^{+} 455.1834$, found 455.1831 .

\subsubsection{2. (3S,4S)-7-ethynyl-4-methoxy-5,8-bis(methoxymethoxy)-3-pentylisochroman-1-one (8a)}

To a solution of aldehyde $12 \mathrm{a}(5.4 \mathrm{mg}, 13.6 \mu \mathrm{mol})$ in $\mathrm{MeOH}(0.14 \mathrm{~mL})$ were added $\mathrm{K}_{2} \mathrm{CO}_{3}(5.7 \mathrm{mg}$, $40.9 \mu \mathrm{mol})$ and Ohira-Bestmann reagent $(3.9 \mathrm{mg}, 20.4 \mu \mathrm{mol})$ at room temperature. After stirring for $40 \mathrm{~min}$ at the same temperature, the mixture was concentrated under reduced pressure. The residue was purified with column chromatography (EtOAc: $n$-hexane $=1: 4$ to 1:1) to give diMOM alkyne derivative $8 \mathrm{a}\left(6.3 \mathrm{mg}\right.$, quant) as a yellow oil. $1 \mathrm{H}-\mathrm{NMR}\left(500 \mathrm{MHz}, \mathrm{CDCl}_{3}\right) \delta 7.52(1 \mathrm{H}, \mathrm{s}), 5.27(1 \mathrm{H}, \mathrm{d}$, $J=6.0 \mathrm{~Hz}), 5.22(2 \mathrm{H}, \mathrm{s}), 5.17(1 \mathrm{H}, \mathrm{d}, J=6.0 \mathrm{~Hz}), 4.59(1 \mathrm{H}, \mathrm{d}, J=1.3 \mathrm{~Hz}), 4.27(1 \mathrm{H}, \mathrm{ddd}, J=1.3,5.8$, $7.4 \mathrm{~Hz}), 3.65(3 \mathrm{H}, \mathrm{s}), 3.49(3 \mathrm{H}, \mathrm{s}), 3.32(3 \mathrm{H}, \mathrm{s}), 2.05(1 \mathrm{H}, \mathrm{m}), 1.82(1 \mathrm{H}, \mathrm{m}), 1.65-1.50(1 \mathrm{H}$, overlapped), $1.42(1 \mathrm{H}, \mathrm{m}), 1.40-1.25\left(4 \mathrm{H}\right.$, overlapped), $0.91(3 \mathrm{H}, \mathrm{t}, J=7.1 \mathrm{~Hz}) ; 13 \mathrm{C}-\mathrm{NMR}\left(125 \mathrm{MHz}, \mathrm{CDCl}_{3}\right) \delta 161.2$, 154.6, 149.5, 130.0, 123.5, 120.4, 120.1, 101.0, 95.2, 82.7, 80.7, 79.3, 68.3, 58.1, 57.0, 56.5, 31.6, 30.5, 24.8, 22.5, 14.0.; IR (KBr) 3260, 2954, 2932, 2861, 2830, 1730, 1155, 1012, $931 \mathrm{~cm}^{-1}$; HRMS (ESI) $m / z(\mathrm{M}+\mathrm{H})^{+}$ calculated for $\left(\mathrm{C}_{21} \mathrm{H}_{29} \mathrm{O}_{7}\right)^{+} 393.1913$, found 393.1903.

\subsubsection{3. (3S,4S)-7-ethynyl-5,8-dihydroxy-4-methoxy-3-pentylisochroman-1-one (8)}

To a solution of diMOM alkyne derivative $8 \mathrm{a}(6.3 \mathrm{mg}, 13.6 \mu \mathrm{mol})$ in $\mathrm{MeOH}(1.2 \mathrm{~mL})$ was added $6 \mathrm{M}$ aqueous $\mathrm{HCl}(0.40 \mathrm{~mL})$ at room temperature. After stirring for $24 \mathrm{~h}$ at the same temperature, the reaction was quenched by adding saturated aqueous $\mathrm{NaHCO}_{3}$ at $0{ }^{\circ} \mathrm{C}$. The mixture was extracted with EtOAc $(\times 3)$ and the combined organic layers were washed with brine, dried over $\mathrm{Na}_{2} \mathrm{SO}_{4}$, filtered, and concentrated under reduced pressure. The residue was purified with column chromatography (EtOAc: $n$-hexane $=1: 4$ to 1:1) to give alkyne derivative $8(3.3 \mathrm{mg}, 67 \%)$ as a yellow solid. m.p. 132-133 ${ }^{\circ} \mathrm{C}$; 1H-NMR $\left(500 \mathrm{MHz}, \mathrm{CDCl}_{3}\right) \delta 11.20(1 \mathrm{H}, \mathrm{s}), 7.22(1 \mathrm{H}, \mathrm{s}), 6.03(1 \mathrm{H}, \mathrm{br}-\mathrm{s}), 4.76(1 \mathrm{H}, \mathrm{d}$, $J=2.5 \mathrm{~Hz}), 4.51(1 \mathrm{H}, \mathrm{ddd}, J=2.5,5.1,8.2 \mathrm{~Hz}), 3.40(3 \mathrm{H}, \mathrm{s}), 3.39(1 \mathrm{H}, \mathrm{s}), 1.94(1 \mathrm{H}, \mathrm{m}), 1.84(1 \mathrm{H}, \mathrm{m})$, 1.70-1.50 (1H, overlapped), $1.45(1 \mathrm{H}, \mathrm{m}), 1.40-1.25(4 \mathrm{H}$, overlapped), $0.91(3 \mathrm{H}, \mathrm{t}, J=7.0 \mathrm{~Hz}) ; 13 \mathrm{C}-\mathrm{NMR}$ $\left(125 \mathrm{MHz}, \mathrm{CDCl}_{3}\right) \delta 168.6,157.3,145.1,127.8,123.4,112.6,108.0,83.2,81.4,77.7,69.7,57.0,31.5,29.7$, 24.8, 22.5, 14.0.; IR (KBr) 3294, 2956, 2930, 2859, 1679, 1434, $1172 \mathrm{~cm}^{-1}$; HRMS (ESI) $\mathrm{m} / z(\mathrm{M}+\mathrm{H})^{+}$ calculated for $\left(\mathrm{C}_{17} \mathrm{H}_{21} \mathrm{O}_{5}\right)^{+}$305.1389, found 305.1391. 
3.1.14. (3S,4S)-4-methoxy-5,8-bis(methoxymethoxy)-1-oxo-3-pentylisochromane-7-carbaldehyde (12a)

A stirred solution of $7 \mathrm{a}(185.1 \mathrm{mg}, 0.469 \mathrm{mmol})$ in $\mathrm{CH}_{2} \mathrm{Cl}_{2}(10.0 \mathrm{~mL})$ was cooled to $-78^{\circ} \mathrm{C}$ and a stream of ozone was passed through it for $30 \mathrm{~min}$. At this time, ozone gas was bubbled into the reaction mixture until the color of the reaction mixture turned to blue. After completion of the reaction, the mixture was purged with oxygen gas for $30 \mathrm{~min}$ before being treated with $\mathrm{PPh}_{3}(246.2 \mathrm{mg}, 0.939$ $\mathrm{mmol}$ ) and allowed to warm to room temperature. After stirring at the same temperature for $12 \mathrm{~h}$, the mixture was concentrated under reduced pressure and the resultant mixture was purified with column chromatography (EtOAc: $n$-hexane $=1: 4$ to $2: 3)$ to give diMOM benzaldehyde derivative 12a (177.4 mg, 95\%) as a white solid. m.p. $38-39^{\circ} \mathrm{C} ; 1 \mathrm{H}-\mathrm{NMR}\left(400 \mathrm{MHz}, \mathrm{CDCl}_{3}\right) \delta 10.42(1 \mathrm{H}, \mathrm{s}), 7.83(1 \mathrm{H}, \mathrm{s}), 5.29(2 \mathrm{H}$, $\mathrm{s}), 5.2(2 \mathrm{H}, \mathrm{s}), 4.65(1 \mathrm{H}, \mathrm{d}, J=1.0 \mathrm{~Hz}), 4.29(1 \mathrm{H}, J=1.0,5.6,8.3 \mathrm{~Hz}), 3.59(3 \mathrm{H}, \mathrm{s}), 3.50(3 \mathrm{H}, \mathrm{s}), 3.35(3 \mathrm{H}, \mathrm{s})$, $2.06(1 \mathrm{H}, \mathrm{m}), 1.83(1 \mathrm{H}, \mathrm{m}), 1.70-1.50(1 \mathrm{H}$, overlapped $), 1.44(1 \mathrm{H}, \mathrm{m}), 1.40-1.30(4 \mathrm{H}$, overlapped), $0.91(3 \mathrm{H}$, $\mathrm{t}, J=7.1 \mathrm{~Hz}) ; 13 \mathrm{C}-\mathrm{NMR}\left(125 \mathrm{MHz}, \mathrm{CDCl}_{3}\right) \delta 189.9,161.4,156.6,150.6,135.8,132.5,120.8,116.9,103.0$, 95.4, 81.0, 68.7, 58.4, 57.8, 57.0, 31.9, 30.8, 25.2, 22.8, 14.3.; IR (KBr) 2957, 2929, 2859, 2829, 1730, 1691, $1379,1155,930 \mathrm{~cm}^{-1}$; HRMS (ESI) $\mathrm{m} / z(\mathrm{M}+\mathrm{H})^{+}$calculated for $\left(\mathrm{C}_{20} \mathrm{H}_{29} \mathrm{O}_{8}\right)^{+}$397.1862, found 397.1866.

\subsubsection{5. (3S,4S)-5,8-dihydroxy-4-methoxy-1-oxo-3-pentylisochromane-7-carbaldehyde (12)}

To a solution of diMOM aldehyde derivative $12 \mathrm{a}(10.0 \mathrm{mg}, 25.2 \mu \mathrm{mol})$ in THF $(1.9 \mathrm{~mL})$ was added 6 $\mathrm{M}$ aqueous $\mathrm{HCl}(0.63 \mathrm{~mL})$ at $0{ }^{\circ} \mathrm{C}$. After stirring for $4 \mathrm{~h}$ at room temperature, the reaction was quenched by adding saturated aqueous $\mathrm{NaHCO}_{3}$ at $0{ }^{\circ} \mathrm{C}$. The mixture was extracted with EtOAc $(\times 3)$ and the combined organic layers were washed with brine, dried over $\mathrm{Na}_{2} \mathrm{SO}_{4}$, filtered, and concentrated under reduced pressure. The residue was purified with PTLC (EtOAc: $n$-hexane $=2: 3$ ) to give benzaldehyde derivative $12(6.0 \mathrm{mg}, 77 \%)$ as a pale yellow solid. m.p. $170{ }^{\circ} \mathrm{C}(\mathrm{dec}) ; 1 \mathrm{H}-\mathrm{NMR}\left(400 \mathrm{MHz}, \mathrm{CDCl}_{3}\right) \delta$ $11.33(1 \mathrm{H}, \mathrm{s}), 10.47(1 \mathrm{H}, \mathrm{s}), 7.70(1 \mathrm{H}, \mathrm{d}, J=1.5 \mathrm{~Hz}), 6.62(1 \mathrm{H}, \mathrm{br}-\mathrm{s}), 4.75(1 \mathrm{H}, \mathrm{d}, J=2.2 \mathrm{~Hz}), 4.49(1 \mathrm{H}, \mathrm{ddd}$, $J=2.2,5.6,8.0 \mathrm{~Hz}), 3.43(3 \mathrm{H}, \mathrm{s}), 2.03(1 \mathrm{H}, \mathrm{s}), 1.88(1 \mathrm{H}, \mathrm{m}), 1.61(1 \mathrm{H}, \mathrm{m}), 1.48(1 \mathrm{H}, \mathrm{m}), 1.42-1.30(4 \mathrm{H}$, overlapped), $0.92(3 \mathrm{H}, \mathrm{t}, J=6.8 \mathrm{~Hz}) ; 13 \mathrm{C}-\mathrm{NMR}\left(125 \mathrm{MHz}, \mathrm{CDCl}_{3}\right) \delta 189.0,168.8,158.9,146.0,131.3$, 124.9, 121.5, 110.2, 82.2, 69.2, 57.9, 31.9, 30.3, 25.1, 22.8, 14.3.; IR (KBr) 3444, 3169, 2953, 2940, 2920, 1676, $1455,1395,1299 \mathrm{~cm}^{-1}$; HRMS (ESI) $\mathrm{m} / \mathrm{z}(\mathrm{M}+\mathrm{H})^{+}$calculated for $\left(\mathrm{C}_{16} \mathrm{H}_{21} \mathrm{O}_{6}\right)^{+} 309.1338$, found 309.1342 .

3.1.16. (3S,4S)-7-(hydroxymethyl)-4-methoxy-5,8-bis(methoxymethoxy)-3-pentylisochroman-1one (11a)

To a solution of diMOM aldehyde derivative 12a (20.0 mg, $50.5 \mu \mathrm{mol})$ in $\mathrm{MeOH}(0.25 \mathrm{~mL})$ was added $\mathrm{NaBH}_{4}(2.1 \mathrm{mg}, 55.5 \mu \mathrm{mol})$ at $0^{\circ} \mathrm{C}$. After stirring for $15 \mathrm{~min}$ at the same temperature, the reaction was quenched by adding water at $0^{\circ} \mathrm{C}$. The mixture was extracted with EtOAc $(\times 3)$ and the combined organic layers were washed with brine, dried over $\mathrm{Na}_{2} \mathrm{SO}_{4}$, filtered, and concentrated under reduced pressure. The residue was purified with PTLC (EtOAc: $n$-hexane $=1: 1$ ) to give diMOM hydroxymethyl derivative 11a $(18.6 \mathrm{mg}, 93 \%)$ as a white wax. $1 \mathrm{H}-\mathrm{NMR}\left(400 \mathrm{MHz}, \mathrm{CDCl}_{3}\right) \delta 7.46(1 \mathrm{H}, \mathrm{s}), 5.25(1 \mathrm{H}, \mathrm{d}$, $J=6.8 \mathrm{~Hz}), 5.24(1 \mathrm{H}, \mathrm{d}, J=6.8 \mathrm{~Hz}), 5.15(2 \mathrm{H}, \mathrm{s}), 4.72(1 \mathrm{H}, \mathrm{dd}, J=6.4,12.5 \mathrm{~Hz}), 4.62(1 \mathrm{H}, \mathrm{d}, J=1.2 \mathrm{~Hz})$, $4.58(1 \mathrm{H}, \mathrm{dd}, J=7.8,12.5 \mathrm{~Hz}), 4.25(1 \mathrm{H}, \mathrm{ddd}, J=1.2,5.8,8.0 \mathrm{~Hz}), 3.64(3 \mathrm{H}, \mathrm{s}), 3.55(1 \mathrm{H}, \mathrm{t}, J=6.8 \mathrm{~Hz})$, $3.50(3 \mathrm{H}, \mathrm{s}), 3.31(3 \mathrm{H}, \mathrm{s}), 2.05(1 \mathrm{H}, \mathrm{m}), 1.83(1 \mathrm{H}, \mathrm{m}), 1.65-1.50(1 \mathrm{H}$, overlapped $), 1.43(1 \mathrm{H}, \mathrm{m}), 1.42-1.30$ (4H, overlapped), $0.91(3 \mathrm{H}, \mathrm{t}, J=6.8 \mathrm{~Hz})$; 13C-NMR $\left(125 \mathrm{MHz}, \mathrm{CDCl}_{3}\right) \delta 162.4,152.7,150.7,138.7,128.9$,

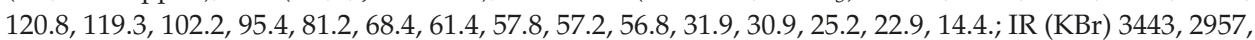
2928, 2859, 2828, 1724, 1153, $1012 \mathrm{~cm}^{-1}$; HRMS (ESI) $\mathrm{m} / \mathrm{z}(\mathrm{M}+\mathrm{H})^{+}$calculated for $\left(\mathrm{C}_{20} \mathrm{H}_{31} \mathrm{O}_{8}\right)+399.2019$, found 399.2017.

\subsubsection{7. (3S,4S)-5,8-dihydroxy-7-(hydroxymethyl)-4-methoxy-3-pentylisochroman-1-one (11)}

To a solution of diMOM hydroxymethyl derivative 11a $(7.2 \mathrm{mg}, 24.1 \mu \mathrm{mol})$ in $\mathrm{MeOH}(1.8 \mathrm{~mL})$ was added $6 \mathrm{M}$ aqueous $\mathrm{HCl}(0.45 \mathrm{~mL})$ at $0{ }^{\circ} \mathrm{C}$. After stirring for $4 \mathrm{~h}$ at $40{ }^{\circ} \mathrm{C}$, the reaction was quenched by adding saturated aqueous $\mathrm{NaHCO}_{3}$ at $0{ }^{\circ} \mathrm{C}$. The mixture was extracted with EtOAc $(\times 3)$ and the combined organic layers were washed with brine, dried over $\mathrm{Na}_{2} \mathrm{SO}_{4}$, filtered, and concentrated under 
reduced pressure. The residue was purified with PTLC (EtOAc: $n$-hexane $=1: 1)$ to give hydroxymethyl derivative 11 (3.9 mg, 52\%) as a white solid. m.p. $143-145^{\circ} \mathrm{C} ; 1 \mathrm{H}-\mathrm{NMR}\left(400 \mathrm{MHz}, \mathrm{CDCl}_{3}\right) \delta 10.99$ $(1 \mathrm{H}, \mathrm{s}), 7.12(1 \mathrm{H}, \mathrm{s}), 6.03(1 \mathrm{H}, \mathrm{br}-\mathrm{s}), 4.74(1 \mathrm{H}, \mathrm{d}, J=2.4 \mathrm{~Hz}), 4.72(2 \mathrm{H}, \mathrm{br}-\mathrm{s}), 4.48(1 \mathrm{H}, \mathrm{ddd}, J=2.4,5.2$, $8.0 \mathrm{~Hz}), 3.38(3 \mathrm{H}, \mathrm{s}), 2.53(1 \mathrm{H}, \mathrm{br}-\mathrm{s}), 1.96(1 \mathrm{H}, \mathrm{m}), 1.86(1 \mathrm{H}, \mathrm{m}), 1.70-1.50(1 \mathrm{H}$, overlapped), $1.46(1 \mathrm{H}, \mathrm{m})$, 1.40-1.25 (4H, overlapped), $0.91(3 \mathrm{H}, \mathrm{t}, J=6.8 \mathrm{~Hz})$; 13C-NMR (125 MHz, $\left.\mathrm{CDCl}_{3}\right) \delta 169.5,154.2,145.8$, $130.8,123.8,121.4,107.8,82.1,69.8,61.2,57.2,31.9,30.2,25.2,22.8,14.3$.; IR (KBr) 2951, 2921, 2854, 1682, $1440,1302 \mathrm{~cm}^{-1}$; HRMS (ESI) $\mathrm{m} / z(\mathrm{M}+\mathrm{H})^{+}$calculated for $\left(\mathrm{C}_{16} \mathrm{H}_{23} \mathrm{O}_{6}\right)^{+} 311.1495$, found 311.1498 .

3.1.18. ((3S,4S)-4-methoxy-5,8-bis(methoxymethoxy)-1-oxo-3-pentylisochroman-7-yl) methylmethanesulfonate (22)

To a solution of diMOM hydroxymethyl derivative $11 \mathrm{a}(7.2 \mathrm{mg}, 24.1 \mu \mathrm{mol})$ in $\mathrm{CH}_{2} \mathrm{Cl}_{2}(0.47 \mathrm{~mL})$ were added $\mathrm{Et}_{3} \mathrm{~N}(10.8 \mu \mathrm{L}, 77.5 \mu \mathrm{mol})$ and $\mathrm{MsCl}(6.0 \mu \mathrm{L}, 77.5 \mu \mathrm{mol})$ at $0{ }^{\circ} \mathrm{C}$. After stirring for $40 \mathrm{~min}$ at the same temperature, the reaction was quenched by adding water at $0{ }^{\circ} \mathrm{C}$. The mixture was extracted with EtOAc $(\times 3)$ and the combined organic layers were washed with brine, dried over $\mathrm{Na}_{2} \mathrm{SO}_{4}$, filtered, and concentrated under reduced pressure. The residue was purified with PTLC (EtOAc: $n$-hexane $=2: 3)$ to give diMOM mesylated derivative $22(30.4 \mathrm{mg}, 91 \%)$ as a white wax. 1H-NMR (400 MHz, $\left.\mathrm{CDCl}_{3}\right) \delta 7.51(1 \mathrm{H}, \mathrm{s}), 5.45(1 \mathrm{H}, \mathrm{d}, J=12.0 \mathrm{~Hz}), 5.37(1 \mathrm{H}, \mathrm{d}, J=12.2 \mathrm{~Hz}), 5.25(2 \mathrm{H}, \mathrm{s}), 5.14(1 \mathrm{H}, \mathrm{d}$, $J=6.6 \mathrm{~Hz}), 5.12(1 \mathrm{H}, \mathrm{d}, J=6.6 \mathrm{~Hz}), 4.62(1 \mathrm{H}, \mathrm{d}, J=1.4 \mathrm{~Hz}), 4.27(1 \mathrm{H}, \mathrm{ddd}, J=1.2,5.6,7.8 \mathrm{~Hz}), 3.59$ $(3 \mathrm{H}, \mathrm{s}), 3.50(3 \mathrm{H}, \mathrm{s}), 3.33(3 \mathrm{H}, \mathrm{s}), 3.07(3 \mathrm{H}, \mathrm{s}), 2.03(1 \mathrm{H}, \mathrm{m}), 1.82(1 \mathrm{H}, \mathrm{m}), 1.58(1 \mathrm{H}, \mathrm{m}), 1.44(1 \mathrm{H}, \mathrm{m})$, 1.40-1.25 (4H, overlapped), $0.91(3 \mathrm{H}, \mathrm{t}, J=6.8 \mathrm{~Hz})$; 13C-NMR $\left(100 \mathrm{MHz}, \mathrm{CDCl}_{3}\right) \delta 161.9,152.2,150.5$, $131.3,130.5,120.3,119.7,102.8,95.5,81.2,68.6,66.9,58.1,57.4,56.9,38.2,31.9,30.9,25.2,22.8,14.3$.; IR (KBr) 2958, 2930, 2860, 1829, 1681, 1440, 1358, 1175, $933 \mathrm{~cm}^{-1}$; HRMS (ESI) $m / z(\mathrm{M}+\mathrm{Na})^{+}$calculated for $\left(\mathrm{C}_{21} \mathrm{H}_{32} \mathrm{O}_{10} \mathrm{SNa}\right)^{+} 499.1614$, found 499.1616 .

3.1.19. (3S,4S)-7-(azidomethyl)-4-methoxy-5,8-bis(methoxymethoxy)-3-pentylisochroman-1-one (13a)

To a solution of diMOM mesylated derivative $22(5.3 \mathrm{mg}, 11.1 \mu \mathrm{mol})$ in DMF $(55 \mu \mathrm{L})$ was added $\mathrm{NaN}_{3}(0.79 \mathrm{mg}, 12.1 \mu \mathrm{mol})$ at room temperature. After stirring for $6 \mathrm{~h}$ at the same temperature, the reaction was quenched by adding water at $0{ }^{\circ} \mathrm{C}$. The mixture was extracted with EtOAc $(\times 3)$ and the combined organic layers were washed with brine, dried over $\mathrm{Na}_{2} \mathrm{SO}_{4}$, filtered, and concentrated under reduced pressure. The residue was purified with PTLC (EtOAc: $n$-hexane $=3: 7$ ) to give diMOM azide derivative 13a $(3.7 \mathrm{mg}, 79 \%)$ as a pale-yellow oil. $1 \mathrm{H}-\mathrm{NMR}\left(500 \mathrm{MHz}, \mathrm{CDCl}_{3}\right) \delta 7.44(1 \mathrm{H}, \mathrm{s}), 5.26(1 \mathrm{H}, \mathrm{d}$, $J=6.9 \mathrm{~Hz}), 5.25(1 \mathrm{H}, \mathrm{d}, J=6.9 \mathrm{~Hz}), 5.13(1 \mathrm{H}, \mathrm{d}, J=6.9 \mathrm{~Hz}), 5.11(1 \mathrm{H}, \mathrm{d}, J=6.9 \mathrm{~Hz}), 4.65(1 \mathrm{H}, \mathrm{d}, J=14.5$ $\mathrm{Hz}), 4.62(1 \mathrm{H}, \mathrm{d}, J=1.3 \mathrm{~Hz}), 4.53(1 \mathrm{H}, \mathrm{d}, J=14.5 \mathrm{~Hz}), 4.27(1 \mathrm{H}, \mathrm{ddd}, J=1.3,5.7,7.3 \mathrm{~Hz}), 3.60(3 \mathrm{H}, \mathrm{s})$, $3.51(3 \mathrm{H}, \mathrm{s}), 3.32(3 \mathrm{H}, \mathrm{s}), 2.04(1 \mathrm{H}, \mathrm{m}), 1.82(1 \mathrm{H}, \mathrm{m}), 1.65-1.50(1 \mathrm{H}$, overlapped), $1.43(1 \mathrm{H}, \mathrm{m}), 1.40-1.30$ (4H, overlapped), $0.91(3 \mathrm{H}, \mathrm{t}, J=7.0 \mathrm{~Hz}) ; 13 \mathrm{C}-\mathrm{NMR}\left(125 \mathrm{MHz}, \mathrm{CDCl}_{3}\right) \delta 162.2,152.1,150.5,133.5$, 129.1, 119.7, 119.5, 102.6, 95.5, 81.2, 68.6, 57.9, 57.3, 56.8, 50.2, 31.9, 30.9, 25.2, 22.9, 14.4.; IR (KBr) 2957, $2928,2858,2829,2105,1729,1153,1009 \mathrm{~cm}^{-1}$; HRMS (ESI) $\mathrm{m} / \mathrm{z}(\mathrm{M}+\mathrm{H})^{+}$calculated for $\left(\mathrm{C}_{20} \mathrm{H}_{30} \mathrm{~N}_{3} \mathrm{O}_{7}\right)^{+}$ 424.2084, found 424.2085 .

\subsubsection{0. (3S,4S)-7-(azidomethyl)-5,8-dihydroxy-4-methoxy-3-pentylisochroman-1-one (13)}

To a solution of diMOM azide derivative 13a (8.3 mg, $19.6 \mu \mathrm{mol})$ in $\mathrm{MeOH}(1.5 \mathrm{~mL})$ was added $6 \mathrm{M}$ aqueous $\mathrm{HCl}(0.49 \mathrm{~mL})$ at room temperature. After stirring for $4 \mathrm{~h}$ at $40{ }^{\circ} \mathrm{C}$, the reaction was quenched by adding saturated aqueous $\mathrm{NaHCO}_{3}$ at $0{ }^{\circ} \mathrm{C}$. The mixture was extracted with EtOAc $(\times 3)$ and the combined organic layers were washed with brine, dried over $\mathrm{Na}_{2} \mathrm{SO}_{4}$, filtered, and concentrated under reduced pressure. The residue was purified with PTLC (EtOAc: $n$-hexane $=3: 7$ ) to give nitro derivative 13 (3.1 mg, 49\%) as a white solid. m.p. 98-99 ${ }^{\circ} \mathrm{C}$; $1 \mathrm{H}-\mathrm{NMR}\left(400 \mathrm{MHz}, \mathrm{CDCl}_{3}\right) \delta 10.98(1 \mathrm{H}, \mathrm{s}), 7.10(1 \mathrm{H}$, s), $5.81(1 \mathrm{H}, \mathrm{br}-\mathrm{s}), 4.78(1 \mathrm{H}, \mathrm{d}, J=2.9 \mathrm{~Hz}), 4.52(1 \mathrm{H}, \mathrm{ddd}, J=2.9,5.4,8.5 \mathrm{~Hz}), 4.45(1 \mathrm{H}, \mathrm{d}, J=14.4 \mathrm{~Hz})$, $4.42(1 \mathrm{H}, \mathrm{d}, J=14.4 \mathrm{~Hz}), 3.41(3 \mathrm{H}, \mathrm{s}), 1.93(1 \mathrm{H}, \mathrm{m}), 1.86(1 \mathrm{H}, \mathrm{m}), 1.70-1.50(1 \mathrm{H}$, overlapped), $1.47(1 \mathrm{H}$, m), 1.40-1.25 (4H, overlapped), $0.91(3 \mathrm{H}, \mathrm{t}, J=7.1 \mathrm{~Hz}) ; 13 \mathrm{C}-\mathrm{NMR}\left(125 \mathrm{MHz}, \mathrm{CDCl}_{3}\right) \delta 169.1,154.4$, 145.7, 126.2, 124.6, 121.8, 108.0, 81.7, 70.4, 57.2, 49.3, 31.9, 30.0, 25.2, 22.8, 14.3.; IR (KBr) 2959, 2924, 2857, 
$2108,1654,1441,1293,1170 \mathrm{~cm}^{-1}$; HRMS (ESI) $\mathrm{m} / \mathrm{z}(\mathrm{M}+\mathrm{H})^{+}$calculated for $\left(\mathrm{C}_{16} \mathrm{H}_{22} \mathrm{~N}_{3} \mathrm{O}_{5}\right)^{+}$336.1559, found 336.1563 .

3.1.21. (3S,4S)-7-(aminomethyl)-4-methoxy-5,8-bis(methoxymethoxy)-3-pentylisochroman-1-one (14a)

To a solution of diMOM azide derivative $13 \mathrm{a}(3.3 \mathrm{mg}, 7.8 \mu \mathrm{mol})$ in $\mathrm{MeOH}(0.78 \mathrm{~mL})$ was added $\mathrm{Et}_{3} \mathrm{~N}(0.10 \mathrm{~mL}, 7.35 \mathrm{mmol})$ and $\mathrm{Pd} / \mathrm{C}(1.6 \mathrm{mg}, 1.5 \mu \mathrm{mol})$ at room temperature. After stirring for $1 \mathrm{~h}$ at the same temperature, the mixture was filtered, and the filtrate was concentrated under reduced pressure. The residue was purified with PTLC ( $\left.\mathrm{MeOH}: \mathrm{CH}_{2} \mathrm{Cl}_{2}=1: 9\right)$ to give diMOM amine derivative 14a $(2.0 \mathrm{mg}, 65 \%)$ as brown oil. 1H-NMR (400 MHz, $\left.\mathrm{CDCl}_{3}\right) \delta 7.49(1 \mathrm{H}, \mathrm{s}), 5.26(2 \mathrm{H}, \mathrm{s}), 5.16(1 \mathrm{H}, \mathrm{d}$, $J=7.2 \mathrm{~Hz}), 5.07(1 \mathrm{H}, \mathrm{d}, J=6.8 \mathrm{~Hz}), 4.61(1 \mathrm{H}, \mathrm{d}, J=1.2 \mathrm{~Hz}), 4.27(1 \mathrm{H}, \mathrm{ddd}, J=1.2,6.0,7.6 \mathrm{~Hz}), 4.00$ $(2 \mathrm{H}, \mathrm{s}), 3.61(3 \mathrm{H}, \mathrm{s}), 3.50(3 \mathrm{H}, \mathrm{s}), 3.32(3 \mathrm{H}, \mathrm{s}), 2.59(1 \mathrm{H}, \mathrm{br}-\mathrm{s}), 2.03(1 \mathrm{H}, \mathrm{m}), 1.82(1 \mathrm{H}, \mathrm{m}), 1.57(1 \mathrm{H}, \mathrm{m})$, $1.43(1 \mathrm{H}, \mathrm{m}), 1.40-1.25\left(1 \mathrm{H}\right.$, overlapped), $0.91(3 \mathrm{H}, \mathrm{t}, J=6.8 \mathrm{~Hz}) ; 13 \mathrm{C}-\mathrm{NMR}\left(125 \mathrm{MHz}, \mathrm{CDCl}_{3}\right) \delta 162.6$, 152.6, 150.5, 128.1, 120.0, 119.0, 102.4, 95.4, 81.2, 68.5, 57.9, 57.2, 56.8, 42.5, 32.0, 30.9, 30.0, 25.2, 22.9, 14.4.; IR (KBr) 2957, 2925, 2857, 2827, 1726, 1470, 1153, $1005 \mathrm{~cm}^{-1}$; HRMS (ESI) $\mathrm{m} / z(\mathrm{M}+\mathrm{H})^{+}$calculated for $\left(\mathrm{C}_{20} \mathrm{H}_{32} \mathrm{NO}_{7}\right)^{+} 398.2179$, found 398.2178.

\subsubsection{2. (3S,4S)-7-(aminomethyl)-5,8-dihydroxy-4-methoxy-3-pentylisochroman-1-one (14)}

To a solution of diMOM amine derivative $14 \mathrm{a}(4.4 \mathrm{mg}, 11.1 \mu \mathrm{mol})$ in $\mathrm{MeOH}(0.83 \mathrm{~mL})$ was added $6 \mathrm{M}$ aqueous $\mathrm{HCl}(0.28 \mathrm{~mL})$ at $0{ }^{\circ} \mathrm{C}$. After stirring for $5 \mathrm{~h}$ at room temperature, the reaction was quenched by adding saturated aqueous $\mathrm{NaHCO}_{3}$ at $0{ }^{\circ} \mathrm{C}$. The mixture was extracted with the mixture of $\mathrm{MeOH}$ and $\mathrm{CH}_{2} \mathrm{Cl}_{2}\left(\mathrm{MeOH}: \mathrm{CH}_{2} \mathrm{Cl}_{2}=1: 4\right)(\times 4)$ and the combined organic layers were dried over $\mathrm{Na}_{2} \mathrm{SO}_{4}$, filtered and concentrated under reduced pressure. The residue was purified with PTLC ( $\mathrm{MeOH}: \mathrm{CHCl}_{3}$ saturated with $\left.\mathrm{NH}_{3}=1: 9\right)$ to give amiomethyl derivative $\mathbf{1 4}(1.1 \mathrm{mg}, 32 \%$ ) as brown solid. m.p. $78-80^{\circ} \mathrm{C}$; $1 \mathrm{H}-\mathrm{NMR}\left(400 \mathrm{MHz}, \mathrm{CDCl}_{3}\right) \delta 6.98(1 \mathrm{H}, \mathrm{s}), 4.59(1 \mathrm{H}, \mathrm{d}, J=1.8 \mathrm{~Hz}), 4.35(1 \mathrm{H}, \mathrm{ddd}$, $J=1.8,6.0,8.0 \mathrm{~Hz}), 3.97(1 \mathrm{H}, \mathrm{d}, J=13.3 \mathrm{~Hz}), 3.88(1 \mathrm{H}, \mathrm{d}, J=13.3 \mathrm{~Hz}), 3.19(3 \mathrm{H}, \mathrm{s}), 1.98(1 \mathrm{H}, \mathrm{m}), 1.83$ $(1 \mathrm{H}, \mathrm{m}), 1.56(1 \mathrm{H}, \mathrm{m}), 1.43(1 \mathrm{H}, \mathrm{m}), 1.40-1.25(4 \mathrm{H}$, overlapped), $0.90(3 \mathrm{H}, \mathrm{t}, J=7.0 \mathrm{~Hz}) ; 13 \mathrm{C}-\mathrm{NMR}$ $\left(125 \mathrm{MHz}, \mathrm{CDCl}_{3}\right) \delta 169.9,154.2,146.2,130.0,125.8,122.9,108.1,82.8,68.5,56.9,42.3,31.9,30.6,25.1$, 22.8, 14,3.; IR (KBr) 2956, 2921, 2857, 1676, 1441, $1171 \mathrm{~cm}^{-1}$; HRMS (ESI) $\mathrm{m} / \mathrm{z}(\mathrm{M}+\mathrm{Na})^{+}$calculated for $\left(\mathrm{C}_{16} \mathrm{H}_{23} \mathrm{NO}_{5} \mathrm{Na}\right)^{+}$332.1474, found 332.1474.

\subsubsection{3. ((3S,4S)-5,8-dihydroxy-4-methoxy-7-nitro-3-pentylisochroman-1-one (15)}

To a solution of $3(28.9 \mathrm{mg}, 89.1 \mu \mathrm{mol})$ in $\mathrm{AcOH}(0.50 \mathrm{~mL})$ was added the mixture of $\mathrm{AcOH}$ and $70 \% \mathrm{HNO}_{3}(0.80 \mathrm{~mL}: 0.20 \mathrm{~mL})$ at $0{ }^{\circ} \mathrm{C}$. After stirring for $10 \mathrm{~min}$ at the same temperature, the reaction was quenched by adding saturated aqueous $\mathrm{NaHCO}_{3}$ at $0{ }^{\circ} \mathrm{C}$. The mixture was extracted with EtOAc $(\times 3)$ and the combined organic layers were washed with saturated aqueous $\mathrm{NaHCO}_{3}$ and brine, dried over $\mathrm{Na}_{2} \mathrm{SO}_{4}$, filtered, and concentrated under reduced pressure. The residue was pathed through $\mathrm{SiO}_{2}$ plug and the resultant mixture of monoMOM nitro derivative $15 \mathrm{a}$ was used for the next reaction without further purification. To a solution of $15 \mathrm{a}$ mixture in $\mathrm{MeOH}(7.5 \mathrm{~mL})$ was added $6 \mathrm{M}$ aqueous $\mathrm{HCl}(2.4 \mathrm{~mL})$ at $0{ }^{\circ} \mathrm{C}$. After stirring for $5 \mathrm{~h}$ at $40{ }^{\circ} \mathrm{C}$, the reaction was quenched by adding saturated aqueous $\mathrm{NaHCO}_{3}$ at $0{ }^{\circ} \mathrm{C}$. The mixture was extracted with EtOAc $(\times 3)$ and the combined organic layers were washed with brine, dried over $\mathrm{Na}_{2} \mathrm{SO}_{4}$, filtered, and concentrated under reduced pressure. The residue was purified with PTLC (EtOAc: $n$-hexane = 1:1) to give nitro derivative $15(21.5 \mathrm{mg}, 74 \%)$ as a yellow solid. m.p. 158-159; 1H-NMR $\left(400 \mathrm{MHz}, \mathrm{CDCl}_{3}\right) \delta 11.89(1 \mathrm{H}, \mathrm{s}), 7.78(1 \mathrm{H}, \mathrm{s}), 6.80(1 \mathrm{H}, \mathrm{br}-\mathrm{s})$, $4.82(1 \mathrm{H}, \mathrm{d}, J=2.6 \mathrm{~Hz}), 4.55(1 \mathrm{H}, \mathrm{ddd}, J=2.6,5.2,8.3 \mathrm{~Hz}), 3.46(3 \mathrm{H}, \mathrm{s}), 1.96(1 \mathrm{H}, \mathrm{m}), 1.86(1 \mathrm{H}, \mathrm{m})$, $1.59(1 \mathrm{H}, \mathrm{m}), 1.47(1 \mathrm{H}, \mathrm{m}), 1.40-1.25(4 \mathrm{H}$, overlapped $), 0.91(3 \mathrm{H}, \mathrm{t}, J=7.1 \mathrm{~Hz}) ; 13 \mathrm{C}-\mathrm{NMR}(125 \mathrm{MHz}$, $\left.\mathrm{CDCl}_{3}\right) \delta 167.5,150.4,144.9,137.6,129.4,119.7,110.7,81.0,70.3,57.6,31.4,29.4,24.7,22.4,14.0$; IR (KBr) 3416, 2962, 2927, 2857, 1679, 1445, 1261, 1018, $800 \mathrm{~cm}^{-1}$; HRMS (ESI) $\mathrm{m} / \mathrm{z}(\mathrm{M}+\mathrm{H})^{+}$calculated for $\left(\mathrm{C}_{15} \mathrm{H}_{20} \mathrm{NO}_{7}\right)^{+} 326.1240$, found 326.1224 . 


\subsubsection{4. (3S,4S)-7-amino-5,8-dihydroxy-4-methoxy-3-pentylisochroman-1-one (16)}

To a solution of nitro derivative $15(5.0 \mathrm{mg}, 15.4 \mu \mathrm{mol})$ in THF $(0.62 \mathrm{~mL})$ and $\mathrm{MeOH}(80 \mu \mathrm{L})$ was added $\mathrm{PtO}_{2}(0.3 \mathrm{mg}, 1.54 \mu \mathrm{mol})$ at room temperature. After stirring for $1.5 \mathrm{~h}$ at the same temperature under hydrogen atmosphere (1 atm), the mixture was passed through a membrane filter to remove $\mathrm{PtO}_{2}$. The mixture was concentrated under reduced pressure and the residue was purified with PTLC (EtOAc: $n$-hexane $=3: 7$, developed by three times) to give nitro derivative $\mathbf{1 6}(4.3 \mathrm{mg}, 95 \%)$ as a yellow solid. m.p. $118-119^{\circ} \mathrm{C}$; $1 \mathrm{H}-\mathrm{NMR}\left(500 \mathrm{MHz}, \mathrm{CDCl}_{3}\right) \delta 10.72(1 \mathrm{H}, \mathrm{s}), 6.45(1 \mathrm{H}, \mathrm{s}), 5.68(1 \mathrm{H}, \mathrm{br}-\mathrm{s}), 4.67$ $(1 \mathrm{H}, \mathrm{d}, J=2.5 \mathrm{~Hz}), 4.46(1 \mathrm{H}, \mathrm{ddd}, J=2.5,5.5,8.3 \mathrm{~Hz}), 4.05(1 \mathrm{H}, \mathrm{br}-\mathrm{s}), 3.32(3 \mathrm{H}, \mathrm{s}), 1.94(1 \mathrm{H}, \mathrm{m}), 1.84$ $(1 \mathrm{H}, \mathrm{m}), 1.75-1.50(1 \mathrm{H}$, overlapped), $1.45(1 \mathrm{H}, \mathrm{m}), 1.40-1.25(4 \mathrm{H}$, overlapped $), 0.90(3 \mathrm{H}, \mathrm{t}, J=7.0 \mathrm{~Hz})$; 13C-NMR $\left(125 \mathrm{MHz}, \mathrm{CDCl}_{3}\right) \delta 169.8,145.9,144.5,137.2,109.8,108.4,106.8,82.4,69.1,56.1,31.6,30.1$, 24.9, 22.5, 14.0; IR (KBr) 3378, 2957, 2926, 2858, 1681, 1464, 1217, $1171 \mathrm{~cm}^{-1}$; HRMS (ESI) $m / z(\mathrm{M}+\mathrm{Na})^{+}$ calculated for $\left(\mathrm{C}_{15} \mathrm{H}_{21} \mathrm{NO}_{5} \mathrm{Na}\right)^{+} 318.1317$, found 318.1321 .

3.1.25. (3S,4S)-7-chloro-8-hydroxy-4-methoxy-5-(methoxymethoxy)-3-pentylisochroman-1-one (18a)

To a solution of $3(5.0 \mathrm{mg}, 15.4 \mu \mathrm{mol})$ in DMF $(0.18 \mathrm{~mL})$ was added the solution of $N$-chlorosuccinimide $(4.1 \mathrm{mg}, 30.8 \mu \mathrm{mol})$ in DMF $(31 \mu \mathrm{L})$ at room temperature. After stirring for $5 \mathrm{~h}$ at $65^{\circ} \mathrm{C}$, the reaction was quenched by adding saturated aqueous $\mathrm{NaHCO}_{3}$ at $0{ }^{\circ} \mathrm{C}$. The mixture was extracted with EtOAc $(\times 3)$ and the combined organic layers were washed with brine, dried over $\mathrm{Na}_{2} \mathrm{SO}_{4}$, filtered, and concentrated under reduced pressure. The residue was purified with PTLC (EtOAc: $n$-hexane $=1: 9)$ to give monoMOM chloro derivative 18a $(3.3 \mathrm{mg}, 60 \%)$ as a brown solid. m.p. 79-81 ${ }^{\circ} \mathrm{C}$; 1H-NMR (400 MHz, CDCl $) \delta 11.23(1 \mathrm{H}, \mathrm{s}), 7.55(1 \mathrm{H}, \mathrm{s}), 5.18(1 \mathrm{H}, \mathrm{d}, J=7.0 \mathrm{~Hz}), 5.16(1 \mathrm{H}, \mathrm{d}$, $J=7.0 \mathrm{~Hz}), 4.59(1 \mathrm{H}, \mathrm{d}, J=1.7 \mathrm{~Hz}), 4.39(1 \mathrm{H}, \mathrm{ddd}, J=1.7,6.0,8.0 \mathrm{~Hz}), 3.50(3 \mathrm{H}, \mathrm{s}), 3.30(3 \mathrm{H}, \mathrm{s}), 2.07$ $(1 \mathrm{H}, \mathrm{m}), 1.86(1 \mathrm{H}, \mathrm{m}), 1.70-1.50(1 \mathrm{H}$, overlapped), $1.47(1 \mathrm{H}, \mathrm{m}), 1.45-1.25(4 \mathrm{H}$, overlapped), $0.92(3 \mathrm{H}, \mathrm{t}$, $J=7.1 \mathrm{~Hz})$; 13C-NMR (125 MHz, $\left.\mathrm{CDCl}_{3}\right) \delta 168.7,152.8,146.3,125.1,123.6,123.0,109.0,95.7,82.7,67.4$, 56.8, 56.4, 31.5, 30.4, 24.7, 22.5, 14.0.; IR (KBr) 2955, 2927, 2853, 2826, 1681, 1453, 1433, $1206 \mathrm{~cm}^{-1}$; HRMS (ESI) $m / z(\mathrm{M}+\mathrm{Na})^{+}$calculated for $\left(\mathrm{C}_{17} \mathrm{H}_{23} \mathrm{O}_{6} \mathrm{ClNa}\right)^{+} 381.1081$, found 381.1088 .

\subsubsection{6. (3S,4S)-7-chloro-5,8-dihydroxy-4-methoxy-3-pentylisochroman-1-one (18)}

To a solution of monoMOM chloro derivative 18a $(3.3 \mathrm{mg}, 9.20 \mu \mathrm{mol})$ in $\mathrm{MeOH}(0.69 \mathrm{~mL})$ was added $6 \mathrm{M}$ aqueous $\mathrm{HCl}(0.23 \mathrm{~mL})$ at $0{ }^{\circ} \mathrm{C}$. After stirring for $2 \mathrm{~h}$ at $40{ }^{\circ} \mathrm{C}$, the reaction was quenched by adding saturated $\mathrm{NaHCO}_{3}$ at $0{ }^{\circ} \mathrm{C}$. The mixture was extracted with EtOAc $(\times 3)$ and the combined organic layers were washed with brine, dried over $\mathrm{Na}_{2} \mathrm{SO}_{4}$, filtered, and concentrated under reduced pressure. The residue was purified with PTLC (EtOAc: $n$-hexane $=1: 9$ ) to give chloro derivative 18 (2.1 mg, 73\%) as a brown solid. m.p. $119-120^{\circ} \mathrm{C} ; 1 \mathrm{H}-\mathrm{NMR}\left(400 \mathrm{MHz}, \mathrm{CDCl}_{3}\right) \delta 11.17(1 \mathrm{H}, \mathrm{br}-\mathrm{s}), 7.34$ $(1 \mathrm{H}, \mathrm{s}), 6.34(1 \mathrm{H}, \mathrm{br}-\mathrm{s}), 4.82(1 \mathrm{H}, \mathrm{br}-\mathrm{s}), 4.59(1 \mathrm{H}, \mathrm{ddd}, J=2.8,5.6,8.4 \mathrm{~Hz}), 3.48(3 \mathrm{H}, \mathrm{s}), 2.03(1 \mathrm{H}, \mathrm{m})$, $1.93(1 \mathrm{H}, \mathrm{m}), 1.64(1 \mathrm{H}, \mathrm{m}), 1.53(1 \mathrm{H}, \mathrm{m}), 1.51-1.35$ (4H, overlapped), $0.98(3 \mathrm{H}, \mathrm{t}, J=7.2 \mathrm{~Hz})$; 13C-NMR $\left(100 \mathrm{MHz}, \mathrm{CDCl}_{3}\right) \delta$ 168.7, 152.1, 145.6, 124.9, 122.8, 121.1, 108.5, 81.8, 69.6, 57.0, 31.5, 29.8, 24.8, 22.5, 14.0.; IR (KBr) 3282, 2958, 2929, 2860, 1681, 1437, $1198 \mathrm{~cm}^{-1}$; HRMS (ESI) $m / z(\mathrm{M}+\mathrm{H})^{+}$calculated for $\left(\mathrm{C}_{15} \mathrm{H}_{20} \mathrm{O}_{5} \mathrm{Cl}\right)^{+} 315.0999$, found 315.0998 .

\subsubsection{7. (3S,4S)-7-bromo-5,8-dihydroxy-4-methoxy-3-pentylisochroman-1-one (19)}

To a solution of bromo derivative $2(11.0 \mathrm{mg}, 24.6 \mu \mathrm{mol})$ in $\mathrm{MeOH}(1.8 \mathrm{~mL})$ was added $6 \mathrm{M}$ aqueous $\mathrm{HCl}(0.62 \mathrm{~mL})$ at $0{ }^{\circ} \mathrm{C}$. After stirring for $3.5 \mathrm{~h}$ at $40^{\circ} \mathrm{C}$, the reaction was quenched by adding saturated aqueous $\mathrm{NaHCO}_{3}$ at $0{ }^{\circ} \mathrm{C}$. The mixture was extracted with EtOAc $(\times 3)$ and the combined organic layers were washed with brine, dried over $\mathrm{Na}_{2} \mathrm{SO}_{4}$, filtered, and concentrated under reduced pressure. The residue was purified with PTLC (EtOAc: $n$-hexane $=1: 9)$ to give bromo derivative 19 (8.6 mg, 97\%) as a white solid. m.p. $132{ }^{\circ} \mathrm{C}$; $1 \mathrm{H}-\mathrm{NMR}\left(400 \mathrm{MHz}, \mathrm{CDCl}_{3}\right) \delta 11.26(1 \mathrm{H}, \mathrm{s}), 7.36(1 \mathrm{H}, \mathrm{s})$, $6.00(1 \mathrm{H}, \mathrm{br}-\mathrm{s}), 4.76(1 \mathrm{H}, \mathrm{d}, J=2.7 \mathrm{~Hz}), 4.52(1 \mathrm{H}, \mathrm{ddd}, J=2.7,5.1,8.3 \mathrm{~Hz}), 3.41(3 \mathrm{H}, \mathrm{s}), 1.95(1 \mathrm{H}, \mathrm{m})$, $1.86(1 \mathrm{H}, \mathrm{m}), 1.70-1.50$ (2H, overlapped), 1.40-1.25 (4H, overlapped), 0.91 (3H, t, J = 7.0 Hz); 13C-NMR 
$\left(125 \mathrm{MHz}, \mathrm{CDCl}_{3}\right) \delta 168.4,153.0,145.8,127.9,121.5,111.6,108.2,81.4,70.0,57.0,31.5,29.6,24.8,22.5$, 14.0.; IR (KBr) 3296, 2955, 2930, 2859, 1679, 1432, $1197 \mathrm{~cm}^{-1}$; HRMS (ESI) $m / z(\mathrm{M}+\mathrm{Na})^{+}$calculated for $\left(\mathrm{C}_{15} \mathrm{H}_{19} \mathrm{O}_{5} \mathrm{BrNa}\right)^{+}$381.0314, found 381.0322 .

\subsubsection{8. (3S,4S)-5,8-dihydroxy-7-iodo-4-methoxy-3-pentylisochroman-1-one (20)}

To a solution of $3(12.6 \mathrm{mg}, 38.8 \mu \mathrm{mol})$ in DMF $(0.35 \mathrm{~mL})$ was added the solution of $N$-iodosuccinimide $(17.5 \mathrm{mg}, 77.6 \mu \mathrm{mol})$ in DMF $(50 \mu \mathrm{L})$ at room temperature. After stirring for $3 \mathrm{~h}$ at room temperature, the reaction was quenched by adding saturated aqueous $\mathrm{NaHCO}_{3}$ at $0{ }^{\circ} \mathrm{C}$. The mixture was extracted with $\mathrm{CH}_{2} \mathrm{Cl}_{2}(\times 3)$ and the combined organic layers were washed with brine, dried over $\mathrm{Na}_{2} \mathrm{SO}_{4}$, filtered, and concentrated under reduced pressure. The residue was pathed through $\mathrm{SiO}_{2}$ plug and the resultant mixture of monoMOM iodo derivative 20a was used for the next reaction without further purification. To a solution of crude mixture of $20 \mathrm{a}$ in $\mathrm{MeOH}(0.83 \mathrm{~mL})$ was added $6 \mathrm{M}$ aqueous $\mathrm{HCl}(0.30 \mathrm{~mL})$ at $0{ }^{\circ} \mathrm{C}$. After stirring for $5 \mathrm{~h}$ at $40{ }^{\circ} \mathrm{C}$, the reaction was quenched by adding saturated aqueous $\mathrm{NaHCO}_{3}$ at $0{ }^{\circ} \mathrm{C}$. The mixture was extracted with EtOAc $(\times 3)$ and the combined organic layers were washed with brine, dried over $\mathrm{Na}_{2} \mathrm{SO}_{4}$, filtered, and concentrated under reduced pressure. The residue was purified with PTLC (EtOAc: $n$-hexane $=1: 9)$ to give iodo derivative $20(4.0 \mathrm{mg}, 87 \%)$ as a pale-yellow oil. m.p. $109-110{ }^{\circ} \mathrm{C} ; 1 \mathrm{H}-\mathrm{NMR}\left(500 \mathrm{MHz}, \mathrm{CDCl}_{3}\right) \delta 11.44(1 \mathrm{H}, \mathrm{s})$, $7.57(1 \mathrm{H}, \mathrm{s}), 6.11$ (1H, br-s), $4.51(1 \mathrm{H}, \mathrm{ddd}, J=2.8,5.4,8.5 \mathrm{~Hz}), 3.40(3 \mathrm{H}, \mathrm{s}), 1.94(1 \mathrm{H}, \mathrm{m}), 1.85(1 \mathrm{H}, \mathrm{m})$, 1.75-1.50 (4H, overlapped), 1.45 (1H, m), 1.40-1.30 (4H, overlapped), 0.91 (3H, t, J = 7.0 Hz); 13C-NMR $\left(125 \mathrm{MHz}, \mathrm{CDCl}_{3}\right) \delta 168.3,155.3,146.3,133.8,122.6,107.1,85.5,81.5,69.8,56.9,31.5,29.7,24.8,22.5$, 14.0; IR (KBr) 3293, 2977, 298, 2857, 1674, 1427, $1197 \mathrm{~cm}^{-1}$; HRMS (ESI) $m / z(\mathrm{M}+\mathrm{Na})^{+}$calculated for $\left(\mathrm{C}_{15} \mathrm{H}_{19} \mathrm{O}_{5} \mathrm{Ina}\right)^{+} 429.0175$, found 429.0174 .

\subsection{Bactericidal Assay}

Methicillin-susceptible Staphylococcus aureus (MSSA) ATCC25923 and methicillin-resistant Staphylococcus aureus (MRSA) ATCC 33,591 were aerobically incubated at $37{ }^{\circ} \mathrm{C}$ in Luria-Bertani medium (LB, Nippon Becton Dickinson Company, Tokyo, Japan). Porphyromonas gingivalis W83 was anaerobically incubated at $37^{\circ} \mathrm{C}$ in Gifu anaerobic medium (GAM, Nissui, Tokyo, Japan). Each culture $(20 \mu \mathrm{L})$ prepared to an optical density of 1.5 at $600 \mathrm{~nm}$ were appropriately incubated with various concentrations of synthesized compounds in $200 \mu \mathrm{L}$ of culture medium at $37^{\circ} \mathrm{C}$ for $24 \mathrm{~h}$ in 96 -well plate (Thermo scientific, MA, USA). Compounds were dissolved in DMSO (Wako, Osaka, Japan). The degree of turbidity in the broth culture was measured at absorbance $600 \mathrm{~nm}$ using microplate reader (Thermo scientific, MA, USA).

\subsection{Cellular Toxicity}

Human lung adenocarcinoma epithelial cell line A549 cells were cultured at $37{ }^{\circ} \mathrm{C}$ in growth medium (DMEM with 10\% fetal bovine serum) in 5\% $\mathrm{CO}_{2}$, and then seeded into 96-well plates at a density of $1 \times 10^{5}$ cells $/ \mathrm{mL}$. Once the cells reached $80 \%-90 \%$ confluence, they were treated with or without $10 \mu \mathrm{M}$ of various compounds at $37^{\circ} \mathrm{C}$ for $12 \mathrm{~h}$. Next, $10 \mu \mathrm{L}$ Cell Counting Kit-8 (Dojindo Molecular Technologies, Kumamoto, Japan) solution was added to each well, and the plate was incubated for $2 \mathrm{~h}$ at $37^{\circ} \mathrm{C}$. Cell viability was determined by measuring the absorbance at $450 \mathrm{~nm}$ using a fluorimeter (Varioscan, Thermo, USA).

\section{Conclusions}

We constructed a chemical library of the side-chain derivatives of eurotiumide A, which is a dihydroisocoumarin-type marine natural product. The antimicrobial evaluation of these compounds was conducted against MSSA, MRSA, and P. gingivalis. We discovered several compounds to be effective against these strains; among them, the isopentyl derivative 6 is especially more active against all three strains than $\mathbf{1}$. Continuous research to clarify the modes of action of these derivatives is under way in our laboratory. 
Supplementary Materials: The following are available online at http://www.mdpi.com/1660-3397/18/2/92/s1, 1Hand 13C-NMR charts of all new compounds.

Author Contributions: A.N. conceived and designed this research and analyzed the experimental data; H.S., T.N., M.H., S.N., and S.K. (Shuhei Kameyama) prepared compounds and collected their spectral data; S.K. (Sangita Karanjit) checked the experimental data; Y.F., N.H., G.K. and M.O. evaluated the antimicrobial activity; A.N., M.O. and K.N. wrote the paper; all of the authors reviewed and approved the manuscript. All authors have read and agreed to the published version of the manuscript.

Funding: This work was supported by JSPS KAKENHI Grant Nos. 17K08365 (A.N.), 18H02657 (M.O.), JP19H02851 (K.N.), and JP16H01156 (K.N.), as well as the Kurita Water and Environment Foundation. We also acknowledge Tokushima University for their financial support of the Research Clusters program of Tokushima University (No. 1802001).

Conflicts of Interest: The authors declare no conflict of interest.

\section{References}

1. Ma, B.; Forney, L.; Ravel, J. Vaginal microbiology: Rethinking health and disease. Annu. Rev. Microbiol. 2012, 66, 371-389. [CrossRef] [PubMed]

2. Buffie, C.G.; Parker, E.G. Microbiota-mediated colonization resistance against intestinal pathogens. Nat. Rev. Immunol. 2013, 13, 790-801. [CrossRef] [PubMed]

3. MCKenney, P.T.; Palmer, E.G. From hype to hope: The gut microbiome in Health and Disease. Cell 2015, 163, 1326-1332. [CrossRef] [PubMed]

4. Lynch, S.V.; Petersen, O. The Human Intestinal Microbiome in Health and Disease. N. Eng. J. M. 2016, 375, 371-389. [CrossRef] [PubMed]

5. Ma, W.H.; Piters, W.A.A.S.; Bogaert, D. The microbiota of the respiratory tract: Gatekeeper to respiratory health. Nat. Rev. Microbiol. 2017, 13, 259-270.

6. Lewis, K. Platforms for Antibiotic Discovery. Nat. Rev. Drug Discovery 2013, 12, 371-387. [CrossRef] [PubMed]

7. Becattini, S.; Taru, Y.; Palmer, E.G. Antibiotic-induced changes in the intestinal microbiota and disease. Trends Mol. Med. 2016, 22, 458-478. [CrossRef]

8. Brown, E.D.; Wright, G.D. Antibacterial Drug Discovery in the Resistance Era. Nature 2016, 529, 336-343. [CrossRef]

9. Fleming, A. On the antibacterial action of cultures of a penicillium with special reference to their use in the isolation of B. influenzae. Br. J. Exp. Pathol. 1929, 10, 226-236. [CrossRef]

10. Chu, D.T.W.; Plattner, J.J.; Katz, L. New Directions in Antibacterial Research. J. Med. Chem. 1996, 39, 3853-3874. [CrossRef]

11. Saleem, M.; Nazir, M.; Ali, M.S.; Hussain, H.; Lee, Y.S.; Riaz, N.; Jabbar, A. Antimicrobial natural products: An update on future antibiotic drug candidates. Nat. Prod. Rep. 2010, 27, 238-254. [CrossRef] [PubMed]

12. Bologa, C.G.; Ursu, O.; Oprea, T.I.; Melancon, C.E., III; Tegos, G.P. Emerging trends in the discovery of natural product antibacterials. Curr. Opin. Pharmacol. 2013, 13, 678-687. [CrossRef] [PubMed]

13. Butler, M.S.; Robertson, A.A.B.; Cooper, M.A. Natural product and natural product derived drugs in clinical trials. Nat. Prod. Rep. 2014, 31, 1612-1661. [CrossRef]

14. Szychowski, J.; Truchon, J.-F.; Bennani, Y.L. Natural Products in Medicine: Transformational Outcome of Synthetic Chemistry. J. Med. Chem. 2014, 57, 9292-9308. [CrossRef] [PubMed]

15. Sclinke, C.; Martins, T.; Queiroz, S.C.; Melo, I.S.; Reyes, F.G.R. Antibacterial Compounds from Marine Bacteria, 2010-2015. J. Nat. Prod. 2017, 80, 1215-1228. [CrossRef] [PubMed]

16. Masscheletin, J.; Henner, M.; Challis, G.L. Antibiotics from Gram-negative bacteria: A comprehensive overview and selected biosynthetic highlights. Nat. Prod. Rep. 2017, 34, 712-783. [CrossRef]

17. Von Nussbaum, F.; Brands, M.; Hizen, B.; Weigand, S.; Habich, D. Antibacterial natural products in medicinal chemistry-exodus or revival? Angew, Chem. Int. Ed. 2006, 45, 5072-5129. [CrossRef]

18. Clardy, J.; Fischbach, M.A.; Walsh, C.T. New antibiotics from bacterial natural product. Nat. Biotechnol. 2006, 24, 1541-1550. [CrossRef]

19. Abouelhassan, Y.; Garrison, A.T.; Yang, H.; Riveros, A.C.; Burch, G.M.; Huigens, R.W., III. Recent Progress in Natural-Product-Inspired Progra,s Aimed To Address Antibiotic Resistance and Tolerance. J. Med. Chem. 2019, 62, 7618-7642. [CrossRef] 
20. Blair, J.M.; Webber, M.A.; Baylay, A.J.; Ogbolu, D.O.; Piddock, L.J.V. Molecular Mechanisms of Antibiotic Resistance. Nat. Rev. Microbiol. 2015, 13, 42-51. [CrossRef]

21. Ali, J.; Rafiq, Q.A.; Ratcliffe, E. Antimicrobial Resistance Mechanisms and Potential Synthetic Treatments. Futur. Sci. OA 2018, 4, FSO290. [CrossRef]

22. Francino, M.P. Antibiotics and the human gut microbiome: Dysbioses and accumulation of resistances. Front. Microbiol. 2016, 6, 1543. [CrossRef] [PubMed]

23. Chen, M.; Shao, C.-L.; Wang, K.-L.; Xu, Y.; She, Z.-G.; Wang, C.-Y. Dihydroisocoumarin derivatives with antifouling activities from a gorgonian-derived Eurotium sp. fungus. Tetrahedron 2014, 70, 9132-9138. [CrossRef]

24. Nakayama, A.; Sato, H.; Karanjit, S.; Hayashi, N.; Oda, M.; Namba, K. Asymmetric Total Syntheses and Structure Revisions of Eurotiumide A and Eurotiumide B, and Their Evaluation as Natural Fluorescent Probes. Eur. J. Org. Chem. 2018. [CrossRef]

25. Nakayama, A.; Sato, H.; Nagano, S.; Karanjit, S.; Imagawa, H.; Namba, K. Asymmetric Total Syntheses and Structure Elucidations of (+)-Eurtiumide F and (+)-Eurotiumide G. Chem. Pharm. Bull. 2019, 67, 953-958. [CrossRef] [PubMed]

26. Katayama, Y.; Ito, T.; Hiramatsu, K. A new class of genetic element, Staphylococcus cassette chromosome mec, encodes methicillin resistance in Staphylococcus aureus. Antimicrob. Agents Chemother. 2000, 44, 1549-1555. [CrossRef]

(C) 2020 by the authors. Licensee MDPI, Basel, Switzerland. This article is an open access article distributed under the terms and conditions of the Creative Commons Attribution (CC BY) license (http://creativecommons.org/licenses/by/4.0/). 

Article

\title{
Impact of the Cultivation Technique on the Production of Secondary Metabolites by Chrysosporium lobatum TM-237-S5, Isolated from the Sponge Acanthella cavernosa
}

\author{
Géraldine Le Goff ${ }^{1, *}$, Philippe Lopes ${ }^{1}$, Guillaume Arcile ${ }^{1}$, Pinelopi Vlachou ${ }^{2}$, \\ Elsa Van Elslande ${ }^{1}$, Pascal Retailleau ${ }^{1}$, Jean-François Gallard ${ }^{1}$, Michal Weis ${ }^{3}$, \\ Yehuda Benayahu ${ }^{3}$, Nikolas Fokialakis ${ }^{2}$ and Jamal Ouazzani ${ }^{1}$ \\ 1 Institut de Chimie des Substances Naturelles ICSN, Centre National de la Recherche Scientifique CNRS, \\ Avenue de la Terrasse, 91198 Gif-sur-Yvette, France; Philippe.lopes@cnrs.fr (P.L.); \\ Guillaume.arcile@cnrs.fr (G.A.); elsa.van-elslande@cnrs.fr (E.V.E.); Pascal.retailleau@cnrs.fr (P.R.); \\ jean-francois.gallard@cnrs.fr (J.-F.G.); jamal.ouazzani@cnrs.fr (J.O.) \\ 2 Division of Pharmacognosy and Chemistry of Natural Products, Department of Pharmacy, \\ National and Kapodistrian University of Athens, 15771 Athens, Greece; pvlachou@pharm.uoa.gr (P.V.); \\ fokialakis@pharm.uoa.gr (N.F.) \\ 3 School of Zoology, George S. Wise Faculty of Life Sciences, Tel Aviv University, Ramat Aviv, \\ Tel Aviv 69978, Israel; mich9@tauex.tau.ac.il (M.W.); yehudab@tauex.tau.ac.il (Y.B.) \\ * Correspondence: geraldine.legoff@cnrs.fr; Tel.: +33-1-69-82-30-05
}

Received: 8 November 2019; Accepted: 26 November 2019; Published: 30 November 2019

\begin{abstract}
The fungi Chrysosporium lobatum TM-237-S5 was isolated from the sponge Acanthella cavernosa, collected from the mesophotic coral ecosystem of the Red Sea. The strain was cultivated on a potato dextrose agar (PDA) medium, coupling solid-state fermentation and solid-state extraction (SSF/SSE) with a neutral macroreticular polymeric adsorbent XAD Amberlite resin (AMBERLITE XAD1600N). The SSF/SSE lead to high chemodiversity and productivity compared to classical submerged cultivation. Ten phenalenone related compounds were isolated and fully characterized by one-dimensional and two-dimensional NMR and HRMS. Among them, four were found to be new compounds corresponding to isoconiolactone, (-)-peniciphenalenin $\mathrm{F},(+)-8$-hydroxyscleroderodin, and (+)-8-hydroxysclerodin. It is concluded that SSF/SSE is a powerful strategy, opening a new era for the exploitation of microbial secondary metabolites.
\end{abstract}

Keywords: solid-state fermentation; solid-state extraction; Chrysosporium lobatum; marine fungi; phenalenone derivatives

\section{Introduction}

The symbiosis between marine sponges and microorganisms is of considerable interest, both biologically and chemically $[1,2]$. Sponges are benthic organisms that have been colonizing different marine ecosystems, including coral reefs, for 600 million years [3,4]. Their survival under drastically changing conditions requires a variety of adaptations, including the evolving strategy of symbiosis with beneficial microorganisms, which has been taking place since the Precambrian Age [5]. The mutualism between marine sponges and microbial symbionts is mainly related to nutrition and defense $[1,6]$, under the control of dedicated enzymes and active secondary metabolites [2]. Although sponges are the main source of bioactive molecules isolated from marine organisms, a certain amount of evidence indicates that they are biosynthesized by microbial symbionts $[7,8]$. This has also been corroborated by the massive presence of microorganisms in the mesophyl matrix of the sponges, representing around $50 \%$ of their biomass [9-11]. 
Fungi in the marine environment, and especially those associated with marine invertebrates, have been extensively investigated and reviewed [12,13]. A 2019 collaborative review highlighted the present state of knowledge and raised a multitude of open questions regarding the diversity and function of fungi in marine ecosystems [13].

The symbiont assemblages inside the sponge are well organized in biofilms or dense colonies and are stabilized in the skeleton network over time [14,15]. This certainly impacts their development steps and the expression of biosynthetic clusters of secondary metabolites because it is now well documented that, in fungi, secondary metabolism and life cycle among fungi are co-regulated at the genomic level [16-18].

This idea drives us to compare the metabolic profile of fungi cultivated on a gar slants and in liquid state. The result is that solid-state cultivation often leads to larger molecular diversity than classical liquid state fermentation LSF [19-21]. The major obstacle that stands against agar cultivation is the scale-up. In order to overcome such a challenge, we have developed specific innovative technologies, namely Platotex [22,23] and, more recently, Unifertex [24]. As we systematically coupled the culture of microorganisms with in-situ solid phase extraction (SPE), we also developed a specific SPE procedure for agar cultivation, termed solid-solid extraction (SSE) [25].

In the present study, we report the impact of agar-supported cultivation on the production of secondary metabolites by the marine fungi Chrysosporium lobatum TM-237-S5, isolated from the Red Sea sponge Acanthella cavernosa. Chrysosporium lobatum was previously reported in the literature as a mosquito pathogenic fungus [26]. However, a very limited number of secondary metabolites have been reported in the literature for the genus Chrysosporium. Thus, the strain Chrysosporium queenslandicum IFM produced naphthaquinone-type altersolanols $\mathrm{A}, \mathrm{B}$, and $\mathrm{C}$, the antifungal queenslandon, a representative of the zearalenone family of mycotoxin, and the antibacterial dihydronaphthaquinones chrysoqueen and chrysolandol [27]. The diterpenoid derivative RPR113228, a farnesyl transferase inhibitor, was also attributed to Chrysosporium lobatum, yet the identification of the strain was only based on morphological analysis [28]. Furthermore, curvularin and dehydroculvilarin were isolated from Chrysosporium lobatum BK-3 [29].

\section{Results and Discussion}

\subsection{The Context of This Work}

The TASCMAR project (Tools And Strategies to access to original bioactive compounds from Cultivation of MARine invertebrates and associated symbionts), funded by the European Union in the frame of the Horizon 2020 framework program, offered the opportunity to investigate the molecules produced by marine invertebrates and their symbionts from mesophotic coral ecosystems (MCEs) (30 to $150 \mathrm{~m}$ depth). Among the invertebrates investigated, the sponge Acanthella cavernosa was collected on the upper mesophotic reef of Eilat at Dekel Beach (51 m depth), in the Gulf of Aqaba (Israel, 2 April $\left.2017,2^{\circ} 32^{\prime} 12.48^{\prime \prime} \mathrm{N} ; 34^{\circ} 56^{\prime} 55.656^{\prime \prime} \mathrm{E}\right)$. The area is characterized by a moderate slope covered with dense patches of hard substrate, mostly calcareous, and is also inhabited by other invertebrates such as octocorals, stony corals, black corals, and sea anemones (Figure 1).

The strain Chrysosporium lobatum TM-237-S5 (Figure 2) was among the strains isolated and identified based on its ITS rDNA sequence (Nuclear ribosomal internal transcribed spacer). 


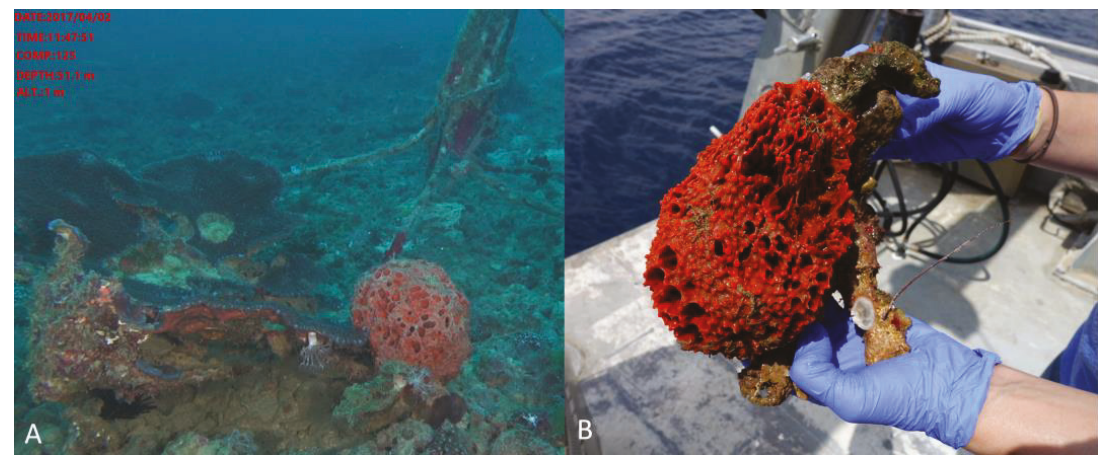

Figure 1. Acanthella cavernosa was collected at $51 \mathrm{~m}$ depth in Eilat, Gulf of Aqaba (Israel). (A) The sponge in its natural environment, (B) The sponge was collected by the remote operating vehicle (ROV) arm, introduced in-situ to the collection basket, and brought to the boat for immediate processing. Two representative pieces were recovered, one for taxonomic identification and the other for symbiont isolation. Both samples were immediately frozen on the boat and shipped in dry ice.

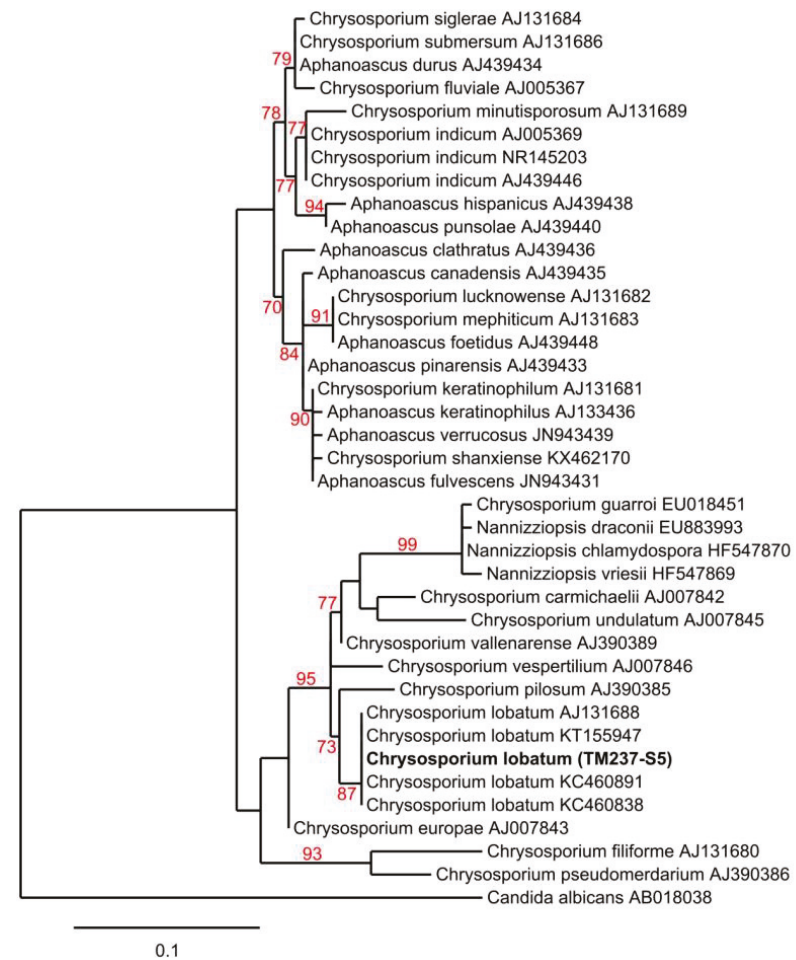

Figure 2. Maximum-likelihood tree obtained from ITS rDNA sequence alignment of the strain TM237-S5 and Chrysosporium spp. Reliability of the internal branch is represented in red. Candida albicans was used as the outgroup. Numbers are Genbank accessions. Th estrain in bold font is the one described in this study. Scale represents substitutions per site. 
The strain was cultivated on potato dextrose broth (PDB), potato dextrose agar (PDA), marine broth (MB), and marine agar (MA). Solid phase extraction (SPE) with XAD resin (AMBERLITETM $X A D^{\mathrm{TM}} 16 H P \mathrm{~N}$ ) was applied in-situ to both liquid (LSF/SPE) and agar-supported cultures (solid-state fermentation and solid-state extraction (SSF/SSE)). It has been previously reported that in-situ XAD extraction coupled to agar-supported cultivation prevents the diffusion of target compounds to the agar layer and traps the target compounds on the resin beads [25].

On day four of incubation (Figure 3E), the resin beads became colored, but were not yet covered by the mycelium (white filaments). On day seven (Figure 3F), the resin beads became darker and the mycelium surface increased. On day 10 (Figure 3G), the recovery time, the resin beads were totally covered by the mycelium. We previously reported that such phenomenon is probably due to the lack of oxygen in the viscous resin layer, which pushes the mycelium to reach the surface to access more oxygen. However, the mycelia remained in contact with the agar to access nutriments, as shown on the agar layer, following the recovery of the resin beads (Figure $3 \mathrm{H}$ ).

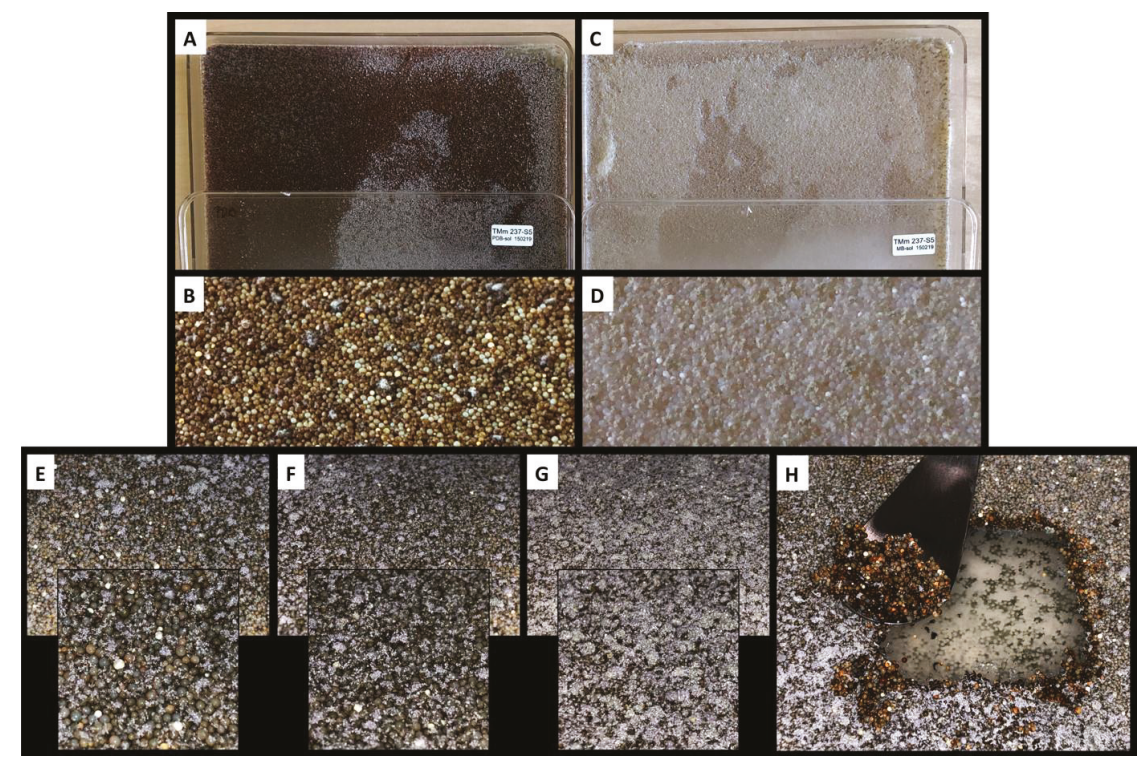

Figure 3. 10 days culture of Chrysosporium lobatum TM-237-S5 on potato dextrose agar (PDA) (A,B) and marine agar (MA) (C,D) coupled to solid-solid extraction (SSE) with XAD resin (AMBERLITE ${ }^{\mathrm{TM}}$ $\left.X A D^{\mathrm{TM}} 16 H P \mathrm{~N}\right)$. The resin beads remained white to light beige on the marine broth (MB) (D), while they turned dark brown on the PDA (B), showing that the resin beads trapped the colored compounds secreted by the strain. (E-G) present the coverage of the resin beads by the mycelium at four, seven, and 10 days. $(\mathbf{H})$ depicts the easy recovery of the resin biofilm layers; the mycelium is not incrusted and no compounds flow to the agar. The resin beads, as revealed by the dark brown color, trapped all the produced compounds.

After 10 days of incubation, the resin beads were recovered by filtration from the liquid cultures $(10 \mathrm{~L})$, and by scraping the surface of the agar cultures $\left(10 \times 625 \mathrm{~cm}^{2}\right.$ petri plates $)$, and washed extensively with water to remove medium residues and any compounds not trapped by the XAD. Resin beads from the PDB, MB, and MA cultures had a light beige color, while the PDA culture was dark brown; most of the color being trapped by the resin beads (Figure 3A-D and Figure 4). 
a

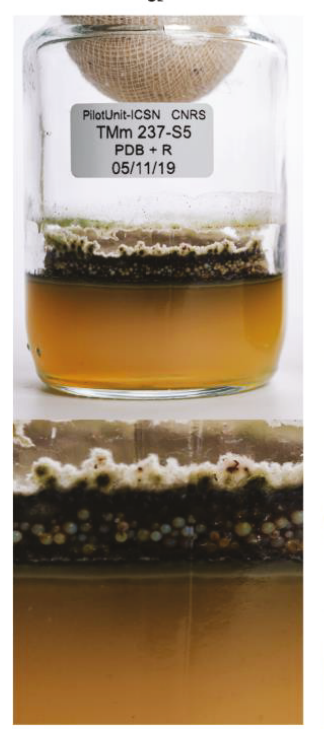

b

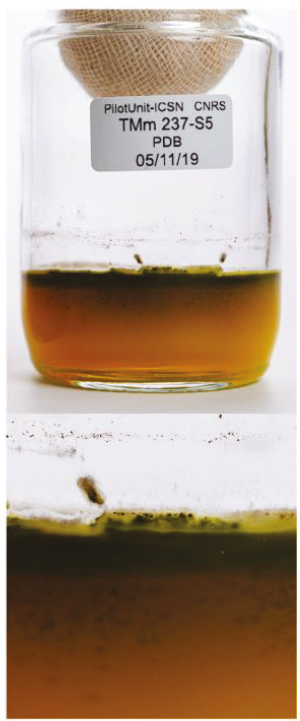

Figure 4. 10 days culture of Chrysosporium lobatum TM-237-S5 on PDA coupled to SSE with XAD ${ }^{\text {TM}} 16 H P$ $\mathrm{N}$ (a) and the control culture on PDA without resin (b). Without the resin (b), the colored compounds were spread in the agar, and their extraction was difficult. With the resin (a), the agar remained clear as the resin beads trapped all the colored target compounds.

The compounds trapped in the XAD were eluted with ethyl acetate and analyzed by HPLC coupled to photodiode array PDA, light-scattering LSD, and mass spectrometry MS detectors (Figure 5). According to the recovered quantities of extracts and the diversity of metabolites observed in the chromatograms, the current study focused on the extract from agar-supported cultivation coupled to in-situ solid-state extraction (SSF/SSE, Figure 5B). This SSF/SSE on PDA lead to an overall extract yield of $872 \mathrm{mg} / \mathrm{m}^{2}$ of cultivation surface, corresponding to $2 \mathrm{~L}$ of medium ( $200 \mathrm{~mL}$ per plate). HPLC analysis revealed 10 peaks with specific UV absorption spectra (Figure 6), which were totally absent in the liquid culture (LSF/SPE) (Figure 5C). 


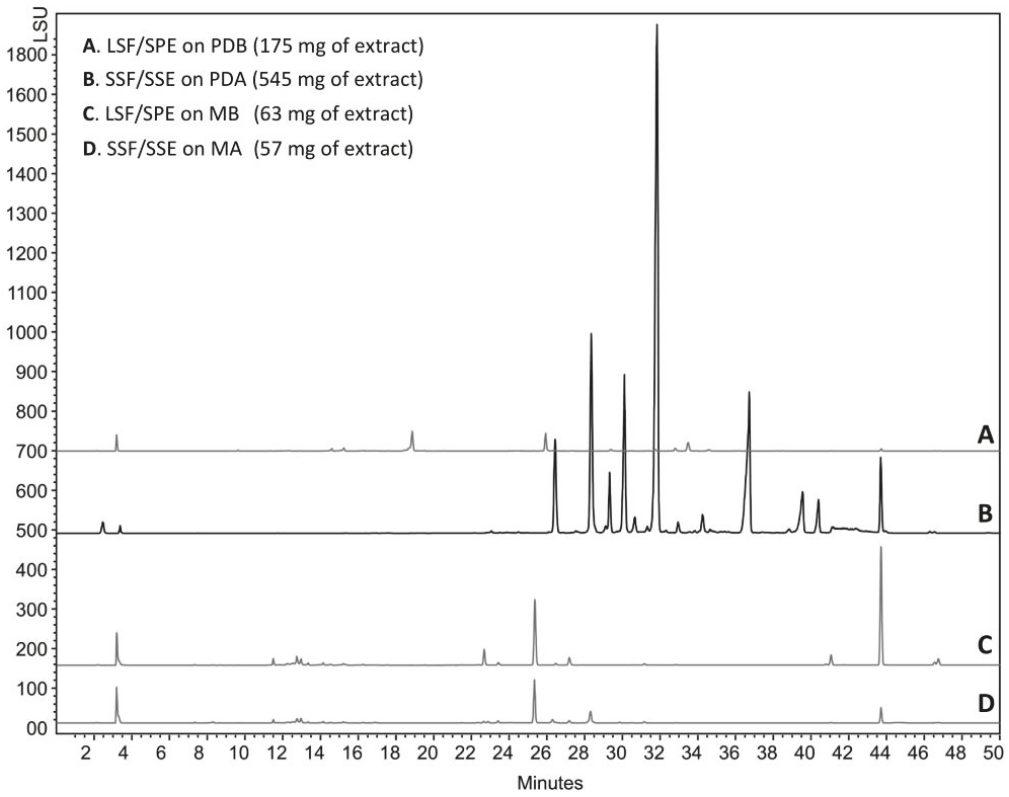

Figure 5. HPLC analysis of the ethyl acetate extract of C. lobatum TM-237-S5 cultivated on different media and support.

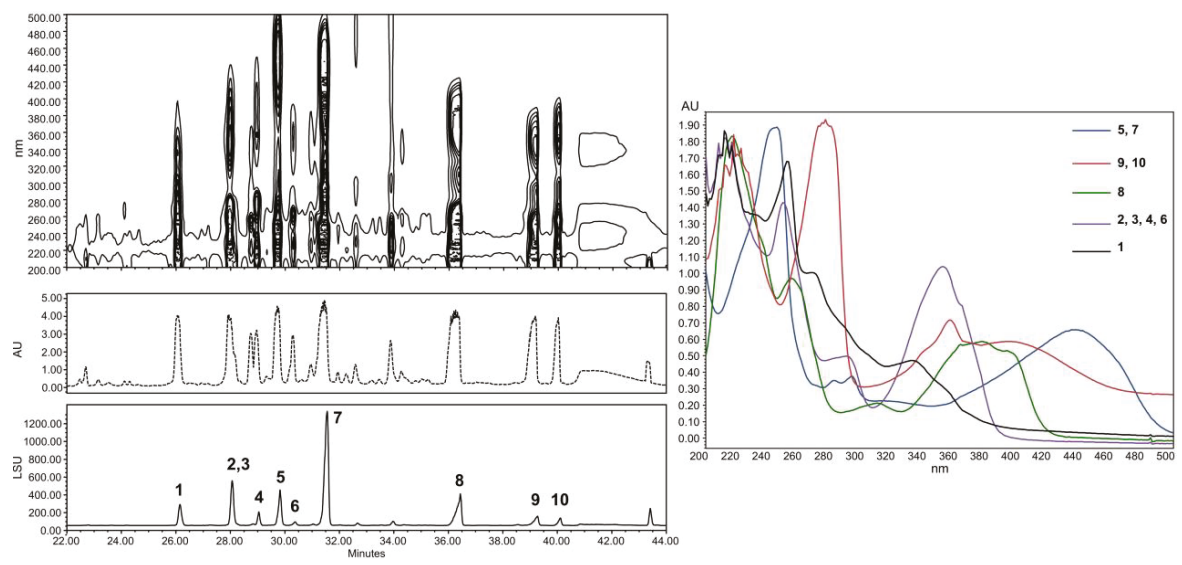

Figure 6. HPLC analysis with LSD and one-dimensional/two-dimensional PDA detections (right). Absorbance spectrum of the compounds investigated.

\subsection{Structural Identification of Compounds $\mathbf{1}$ to $\mathbf{1 0}$}

Compounds 1 to $\mathbf{1 0}$ in Figure 7 were purified and submitted to one-dimensional and two-dimensional NMR and HRMS analysis. Six compounds were unambiguously identified as peniciphenalenin D (1), isolated from Pebnicillium sp. ZZ901 [30], coniolactone (3), (-)-7,8-Dihydro-3,6-dihydroxy-1,7,7,8-tetramethyl-5H-furo-[2',3':5,6] naphtho[1,8-bc]furan-5-one (6), coniosclerodin (9), isolated from Coniothyrium cereale [30,31], (+)-scleroderolide (7), isolated from Gremmeniella abietina [32,33], and (+)-sclerodin (10), isolated from Aspergillus silvaticus [34]. 
<smiles>CC1OC2=C(C(=O)C(=O)c3c(I)cc(O)c(C(=O)O)c32)C1(C)C</smiles><smiles></smiles><smiles>CCC1Oc2c(c(O)c3c4c(c(C)cc(O)c24)C(=O)O3)C1(C)C</smiles><smiles></smiles><smiles>CCC1Oc2c(C)cc(O)c3c2C(=C(O)C3=O)C1(C)C</smiles>

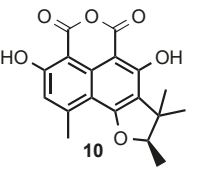<smiles>CC(C)=CCOC1=CC(O)=C2Oc3c(C)cc(O)c(c31)C(=O)OC2=O</smiles>

Figure 7. Structures of the compounds produced by Chrysosporium lobatum TM-237-S5, cultivated for 10 days on PDA medium coupling solid-state fermentation with solid-state extraction (SSF/SSE).

Compounds 2, 4, 5, and 8 were submitted to dereplication based on the Antibase database of microbial compounds (Wiley-VCH) and the natural compounds Reaxys database (Elsevier). Spectroscopic data of these compounds did not match the previously reported compounds or present significant differences, and were submitted to de-novo structural elucidation. Their ${ }^{1} \mathrm{H}$ and ${ }^{13} \mathrm{C}$ NMR data are shown in Tables 1 and 2.

Table 1. ${ }^{13} \mathrm{C}$ NMR (125 and $\left.150 \mathrm{MHz}\right)$ of compounds $2,4,5$, and 8.

\begin{tabular}{|c|c|c|c|c|}
\hline \multirow{2}{*}{ Position } & \multicolumn{4}{|c|}{$\delta_{C}$, Type } \\
\hline & $2^{a}$ & $4^{a}$ & $5^{a}$ & $8^{b}$ \\
\hline 1 & $160.2, \mathrm{C}$ & $160.2, \mathrm{C}$ & $138.9, \mathrm{C}$ & $160.0, \mathrm{C}$ \\
\hline 2 & $118.9, \mathrm{CH}$ & $118.5, \mathrm{C}$ & $144.9, \mathrm{C}$ & $140.4, \mathrm{C}$ \\
\hline 3 & 149.1, C & $147.8, \mathrm{C}$ & $120.5, \mathrm{C}$ & $130.3, \mathrm{C}$ \\
\hline 4 & $112.5, \mathrm{C}$ & 108.2, C & 109.3, C & $108.9, \mathrm{C}$ \\
\hline 5 & $140.2, \mathrm{C}$ & $132.9, \mathrm{C}$ & $132.9, \mathrm{C}$ & $131.9, \mathrm{C}$ \\
\hline 6 & $100.0, \mathrm{C}$ & 100.1, C & 117.4, C & $92.9, \mathrm{C}$ \\
\hline 7 & $168.1, \mathrm{C}$ & 168.7, C & $170.8, \mathrm{C}$ & $165.7, \mathrm{C}$ \\
\hline 8 & - & - & $171.2, \mathrm{C}$ & 165.7, C \\
\hline 9 & $126.5, \mathrm{C}$ & $127.4, \mathrm{C}$ & $108.1, \mathrm{C}$ & $91.8, \mathrm{C}$ \\
\hline 10 & $139.5, \mathrm{C}$ & $139.3, \mathrm{C}$ & 166.7, C & $162.8, \mathrm{C}$ \\
\hline 11 & $99.8, \mathrm{CH}$ & $122.1, \mathrm{C}$ & $120.5, \mathrm{C}$ & $119.8, \mathrm{C}$ \\
\hline 12 & $156.4, \mathrm{C}$ & $153.8, \mathrm{C}$ & $158.5, \mathrm{C}$ & $153.9, \mathrm{C}$ \\
\hline 13 & $66.8, \mathrm{CH}_{2}$ & $91.4, \mathrm{CH}$ & 93.7, CH & $91.7, \mathrm{CH}$ \\
\hline 14 & $120.8, \mathrm{CH}$ & 46.0, C & $44.3, \mathrm{C}$ & $43.4, \mathrm{C}$ \\
\hline 15 & $139.2, \mathrm{C}$ & $14.6, \mathrm{CH}_{3}$ & $14.9, \mathrm{CH}_{3}$ & $14.1, \mathrm{CH}_{3}$ \\
\hline 16 & $25.8, \mathrm{CH}_{3}$ & 21.3, $\mathrm{CH}_{3}$ & $21.2, \mathrm{CH}_{3}$ & 20.3, $\mathrm{CH}_{3}$ \\
\hline 17 & $18.3, \mathrm{CH}_{3}$ & $26.3, \mathrm{CH}_{3}$ & $25.9, \mathrm{CH}_{3}$ & $25.2, \mathrm{CH}_{3}$ \\
\hline 18 & $23.0, \mathrm{CH}_{3}$ & $21.4, \mathrm{CH}_{3}$ & $13.7, \mathrm{CH}_{3}$ & $13.9, \mathrm{CH}_{3}$ \\
\hline
\end{tabular}

$\mathrm{a}, \mathrm{b}$; the spectra were recorded in $\mathrm{MeOD}$ and $\mathrm{CD}_{2} \mathrm{Cl}_{2}$, respectively.

The peak at 28 min exhibits a molecular formula of $\mathrm{C}_{17} \mathrm{H}_{16} \mathrm{O}_{5}$, determined by HRESIMS $(\mathrm{m} / \mathrm{z}$ $\left.301.1076[\mathrm{M}+\mathrm{H}]^{+}\right)$. A careful ${ }^{1} \mathrm{H}$ and ${ }^{13} \mathrm{C}$ NMR analysis of the peak at $28 \mathrm{~min}$ revealed a mixture of two compounds with indistinguishable HRMS. De-replication and comparison with published results showed that one of the constituents was unambiguously coniolactone (3). As well as 3, HMBC correlations showed that compound 2 differs only at the ring $\mathrm{C}$ configuration. A key HMBC correlation from H-2 $\left(\delta_{\mathrm{H}} 6.70, \mathrm{~s}\right)$ to the carbonyl C-7 $\left(\delta_{\mathrm{C}} 168.1\right)$ indicated that, in 2 , the carbonyl at C-7 is connected to C-6 rather than to C-9 in coniolactone (3) (Figure 8). So far, all our attempts to separate 2 and 3 by different chromatographic techniques have failed. Compound 2 was named isoconiolactone. 
Table 2. ${ }^{1} \mathrm{H}$ NMR (500 and $600 \mathrm{MHz}$ ) of compounds 2, 4, 5 and 8.

\begin{tabular}{|c|c|c|c|c|}
\hline \multirow{2}{*}{ Position } & \multicolumn{4}{|c|}{$\delta_{\mathrm{H}}$, Mult. $(J$ in $\mathrm{Hz})$} \\
\hline & $2^{a}$ & $4^{a}$ & $5^{a}$ & $8^{b}$ \\
\hline 1 & - & - & - & \\
\hline 2 & $6.70, \mathrm{~s}$ & $6.70, \mathrm{~s}$ & - & \\
\hline 3 & - & - & - & \\
\hline 4 & - & - & - & \\
\hline 5 & - & - & - & \\
\hline 6 & - & - & - & \\
\hline 7 & - & - & - & \\
\hline 8 & - & - & - & \\
\hline 9 & - & - & - & \\
\hline 10 & - & - & - & \\
\hline 11 & $6.35, \mathrm{~s}$ & - & - & \\
\hline 12 & - & - & - & \\
\hline 13 & $4.60, \mathrm{~d}(6.4)$ & $4.50, \mathrm{q}(6.5)$ & $4.78, \mathrm{q}(6.6)$ & $4.71, \mathrm{q}(6.6)$ \\
\hline 14 & 5.57, br m & - & - & - \\
\hline 15 & - & $1.43, \mathrm{~d}(6.5)$ & $1.52, \mathrm{~d}(6.7)$ & $1.50, \mathrm{~d}(6.6)$ \\
\hline 16 & $1.83, \mathrm{~s}$ & $1.23, \mathrm{~s}$ & $1.31, \mathrm{~s}$ & $1.30, \mathrm{~s}$ \\
\hline 17 & $1.80, \mathrm{~s}$ & $1.50, \mathrm{~s}$ & $1.56, \mathrm{~s}$ & $1.54, \mathrm{~s}$ \\
\hline 18 & $2.76, \mathrm{~s}$ & $2.73, \mathrm{~s}$ & $2.61, \mathrm{~s}$ & $2.79, \mathrm{~s}$ \\
\hline $\mathrm{OH}-10$ & & & & $11.36, \mathrm{~s}$ \\
\hline
\end{tabular}

a,b; the spectra were recorded in MeOD and $\mathrm{CD}_{2} \mathrm{Cl}_{2}$, respectively.

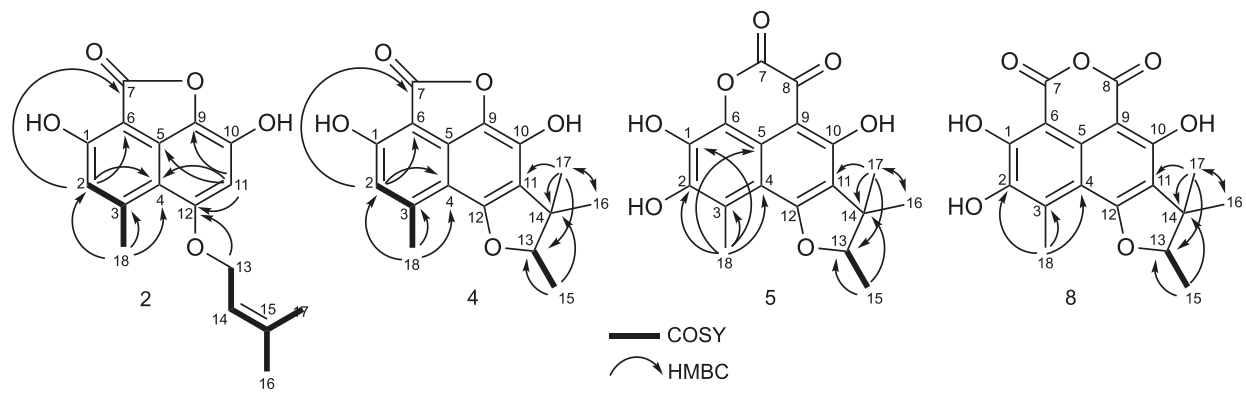

Figure 8. COSY and key HMBC correlations for compounds 2, 4, 5, and 8.

Compound 4 has a molecular formula $\mathrm{C}_{17} \mathrm{H}_{16} \mathrm{O}_{5}$, deduced from HRESIMS and NMR data (Tables 1 and 2). According to NMR and MS data, 4 has the same planar structure as the already known fungal metabolite peniciphenalenin F [30]. However, compound 4 and peniciphenalenin $\mathrm{F}$ have an opposite optical rotation; negative for $4\left(-36.10^{\circ}(\mathrm{c} 0.10, \mathrm{MeOH})\right)$ and positive for the reported peniciphenalenin $\mathrm{F}\left(+16.50^{\circ}\right.$ (c $\left.\left.0.50, \mathrm{MeOH}\right)\right)$. Subsequently, 4 was named (-)-peniciphenalenin F.

Compound 5 had a molecular formula of $\mathrm{C}_{18} \mathrm{H}_{16} \mathrm{O}_{7}$, deduced from HRESIMS and NMR data (Tables 1 and 2). The NRM data of 5 indicates the presence of two carbonyls, eight aromatic carbons, one oxymethine, one quaternary carbon, and four methyls. NMR comparison with previously reported phenalenone derivatives has shown similarities with the isolated (+)-scleroderolide (7) [32,33], except in the C-2 position. Indeed, the aromatic proton, $\mathrm{H}-2$, of scleroderolide is substituted in $\mathbf{5}$ by a hydroxyl group in C-2 $\left(\delta_{C} 144.9\right)$. This finding is also supported by key HMBC correlations from $\mathrm{H}-18(2.61,3 \mathrm{H}$, s) to $C-2\left(\delta_{C} 144.9\right), C-3\left(\delta_{C} 120.5\right)$, and $C-4\left(\delta_{C} 109.3\right)$. Accordingly, compound 5 has been identified as a new phenalenone derivative and was named (+)-8-hydroxyscleroderolide.

Compound 8 has a molecular formula $\mathrm{C}_{18} \mathrm{H}_{16} \mathrm{O}_{7}$, deduced from the HRESIMS and NMR data (Tables 1 and 2). Here again, the NRM data of 8 showed the presence of two carbonyl, eight aromatic carbons, one oxymethine, one quaternary carbon, and four methyls. The NMR data of 8 closely 
resemble those of the previously described and isolated (+)-sclerodin (10) [34], except in the C-2 position. The aromatic proton, $\mathrm{H}-2$, of the sclerodin structure is substituted in $\mathbf{8}$ by a hydroxyl group in $\mathrm{C}-2\left(\delta_{\mathrm{C}} 140.4\right)$. This finding is supported by key HMBC correlations from $\mathrm{H}-18(2.79,3 \mathrm{H}, \mathrm{s})$ to C-2 $\left(\delta_{\mathrm{C}}\right.$ $140.4), C-3\left(\delta_{C} 130.3\right)$, and C-4 ( $\left.\delta_{C} 108.9\right)$.

The structure of $\mathbf{8}$, including the absolute configuration $(13 R)$, is secured by a single crystal $\mathrm{X}$-ray crystallographic analyses using anomalous scattering of Mo then $\mathrm{CuK} \alpha$ radiation through Bijvoet analysis [35], combining maximum likelihood estimation and Bayesian statistics (Figure 9). Therefore, compound 8 was named (+)-8-hydroxyslerodin.

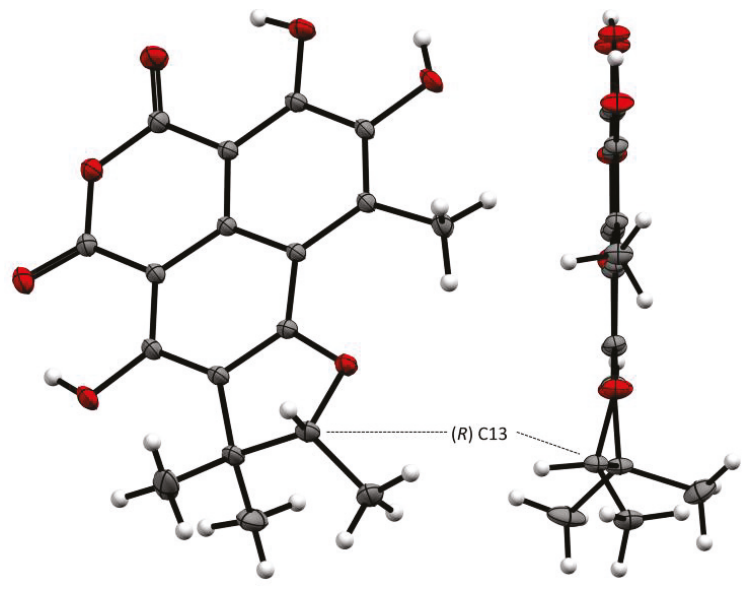

Figure 9. The Oak Ridge Thermal Ellipsoid Plot ORTEP diagram of 8.

The current study presents the breakthrough advantage of solid-state fermentation coupled with in-situ solid phase extraction (SSF/SSE). Indeed, SSF/SSE leads to a large chemical diversity and higher yields. In addition, the concentration of the target compounds on the resin beads represents an economic and ecofriendly recovery process involving limited quantities of water for medium preparation, limited use of power for static incubation, a limited amount of solvents for the elution of compounds, and reduced waste. We also solved the issue of scale-up on the Platotex technology, offering a reusable $2 \mathrm{~m}^{2}$ cultivation surface, and more recently on the Unifertex technology.

\section{Materials and Methods}

\subsection{General Experimental Procedures}

Optical rotations, $[\alpha]_{\mathrm{D}}$, were measured using an Anton Paar MCP-300 polarimeter at $589 \mathrm{~nm}$ (Anton Paar, Les Ulis, France). NMR experiments were performed using a Bruker Avance III $600 \mathrm{MHz}$ spectrometer equipped with a TCi cryo-probe head for compounds 8, 9, and 10, and a Bruker Avance $500 \mathrm{MHz}$ spectrometer for compounds 1 to 7 (Bruker, Vienna, Austria). The spectra were acquired in $\mathrm{CD}_{3} \mathrm{OD}\left(\delta_{\mathrm{H}} 3.31 \mathrm{ppm}\right.$ and $\left.\delta_{\mathrm{C}} 49.15 \mathrm{ppm}\right)$, in $\mathrm{CD}_{2} \mathrm{Cl}_{2}\left(\delta_{\mathrm{H}} 5.32 \mathrm{ppm}\right.$ and $\left.\delta_{\mathrm{C}} 53.10 \mathrm{ppm}\right)$ or in Acetone- $d_{6}$ $\left(\delta_{\mathrm{H}} 2.04 \mathrm{ppm}\right.$ and $\delta_{\mathrm{C}} 29.8 \mathrm{ppm}$ and $\left.206.5 \mathrm{ppm}\right)$ at 300K. High-resolution mass spectra were obtained on a Waters LCT Premier XE spectrometer equipped with an electrospray-time of flight (ESI-TOF) by direct infusion of the purified compounds (Waters SAS, Saint-Quentin-en-Yvelines, France). Pre-packed silica gel Redisep columns were used for flash chromatography using a Combiflash-Companion chromatogram (Serlabo, Entraigues-sur-la-Sorgue, France). All other chemicals and solvents were purchased from SDS (SDS, Peypen, France).

The analytical HPLC system consisted of an Alliance Waters 2695 controller coupled with a PhotoDiode Array Waters 2996, an evaporative light-scattering detector ELSD Waters 2424 detector and 
a mass detector Waters QDa (Waters SAS, Saint-Quentin-en-Yvelines, France). A Sunfire $\mathrm{C}_{18}$ column $(4.6 \times 150 \mathrm{~mm}, 3.5 \mu \mathrm{m})$ was used with a flow rate of $0.7 \mathrm{~mL} / \mathrm{min}$. The elution gradient consisted of a linear gradient from $100 \%$ solvent A to $100 \%$ solvent B in $40 \mathrm{~min}$, then $10 \mathrm{~min}$ at $100 \%$ B (Solvent A: $\mathrm{H}_{2} \mathrm{O}+0,1 \mathrm{HCOOH}$, Solvent B: ACN $\left.+0,1 \% \mathrm{HCOOH}\right)$. Preparative HPLC was performed on a semi-preparative Sunfire $C_{18}$ column $(10 \times 250 \mathrm{~mm}, 5 \mu \mathrm{m})$ using a Waters autosampler 717, a pump 600, a photodiode array detector 2996, and an ELSD detector 2420 (Waters SAS, Saint-Quentin-en-Yvelines, France). XAD resin (AMBERLITE ${ }^{\mathrm{TM}} X A D^{\mathrm{TM}} 16 H P \mathrm{~N}$ ) was purchased from DOW (DOW France SAS, Saint-Denis, France).

\subsection{Invertebrate Collection}

The sponge, Acanthella cavernosa, was collected by a ROV H800 (ECA, Lannion, France) on the upper mesophotic reef of Eilat at Dekel Beach at $51 \mathrm{~m}$ depth in the Gulf of Aqaba, Israel (2 April 2017, $\left.29^{\circ} 32^{\prime} 12.48^{\prime \prime} \mathrm{N} ; 34^{\circ} 56^{\prime} 55.656^{\prime \prime} \mathrm{E}\right)$. The sponge was identified by Dr. Nicole J. de Voogd from Naturalis, Biodiversity Research Center, Leiden, the Netherlands. Collection of animals complied with a permit issued by the Israel Nature and National Parks Protection Authority.

\subsection{Strain Isolation and Identification}

Chrysosporium lobatum TM-237-S5 was isolated from a $1 \mathrm{~cm}^{3}$ sample of Acanthella cavernosa. The invertebrate was immediately stored after collection and conserved at $-20{ }^{\circ} \mathrm{C}$ until lab work processing. Part of the invertebrate $\left(1 \mathrm{~cm}^{3}\right)$ was ground in sterile sea water and heated at $50{ }^{\circ} \mathrm{C}$ for $1 \mathrm{~h}$. The suspension was serially diluted, plated on selective isolation media, and incubated at $28^{\circ} \mathrm{C}$ for at least 6 weeks. The strain was isolated from marine agar medium. The colony was purified on PDA and MA media and preserved in $10 \%$ glycerol solution.

Genomic DNA of the strain TM237-S5 was isolated using a DNeasy Plant Mini Kit (Qiagen), according to the manufacturer's instructions. The ITS region was amplified with primers ITS1F (5'-CTTGGTCATTTAGAGGAAGTAA - $3^{\prime}$ ) and ITS4 (5'-TCCTCCGCTTATTGATATGC) using described polymerase chain reaction (PCR) conditions [36]. Amplicons were sequenced by Sanger sequencing (GATC, Eurofins genomics), and the sequences were aligned against the non-redundant database of the NCBI using the BLASTn program. Then, phylogeny inference was performed on the Phylogeny.fr platform and comprised the following steps [37]: Sequences from TM237-S5 and representative Chrysosporium and Chrysosporium-related sequences described by Gurung et al. (2018) were aligned with MUSCLE (v3.8.31) [38]. After alignment, ambiguous regions were removed with Gblocks (v0.91b) [39]. The phylogenetic tree was reconstructed using the maximum likelihood method implemented in the PhyML program (v3.0 aLRT) [40], and reliability for internal branch was assessed using the aLRT test [41]. Graphical representation and edition of the phylogenetic tree were performed with TreeDyn (v198.3) [42]. The strain Chrysosporium lobatum TM237-S5 was assigned the GenBank number MN080876.

\subsection{Microbial Cultivation}

Chrysosporium lobatum TM-237-S5 spores were conserved at $-20{ }^{\circ} \mathrm{C}$ in $10 \%$ glycerol. Before cultivation, the strain was revived for 5 days on a $15 \mathrm{~cm}$ petri plate containing potato dextrose agar (PDA). Sterile water $(4 \times 10 \mathrm{~mL})$ was poured on the plate surface, and the spores were recovered from the plates by gentle scratching of the surface with a scalpel. Three plates offer $100 \mathrm{~mL}$ of concentrated spore suspension. Ten bottles were filled with $30 \mathrm{~g}$ of XAD Resin (AMBERLITE ${ }^{\mathrm{TM}}$ XAD $^{\mathrm{TM}} 16 \mathrm{HP}$ $\mathrm{N}$ ) and sterilized. $10 \mathrm{~mL}$ of Water and $10 \mathrm{~mL}$ of spore suspension were introduced in each resin containing bottle. The mixture was stirred, poured on a $25 \times 25 \mathrm{~cm}$ petri plate containing PDA medium, homogeneously spread on the surface of the plate, and incubated at $27^{\circ} \mathrm{C}$. Preparative cultures were engaged on $1025 \times 25 \mathrm{~cm}$ petri plates. 


\subsection{Extraction/Purification Procedures}

On day 10 of incubation, the resin/mycelium layer was recovered from the surface of the plates and re-suspended three times in $500 \mathrm{~mL}$ of Ethyl Acetate. Traces of water were removed on anhydrous sodium sulfate, and the solvent evaporated under reduced pressure. $550 \mathrm{mg}$ of dry extract was recovered and submitted for analytical and structural analysis. The extract was fractionated by flash chromatography using a Combiflash-companion chromatogram, and the compounds were further purified by preparative HPLC to offer 6 to $56 \mathrm{mg}$ of pure compound.

\subsection{Structural Elucidation}

All the compounds were submitted to one-dimensional and two-dimensional NMR analysis, high resolution mass spectrometry, and, when appropriate, to crystallography.

Peniciphenalenin D (1): Red amorphous solid (31 mg); $[\alpha]_{\mathrm{D}}^{25}:+119.70^{\circ}(c$ 0.1, MeOH); UV (MeOH) $\lambda_{\max }(\log \varepsilon) 217$ (3.83), 279 (3.85), 369 (2.91), 515 (2.90) nm; ${ }^{1} \mathrm{H}$ and ${ }^{13} \mathrm{C}$ NMR data, see Supplementary Information; HRESIMS m/z $317.1005[\mathrm{M}+\mathrm{H}]^{+}$(calcd. for $\mathrm{C}_{17} \mathrm{H}_{17} \mathrm{O}_{6}, 317.1025$ ).

Isoconiolactone (2) + Coniolactone (3): Orange amorphous powder (40 mg); UV (MeOH) $\lambda_{\max }(\log \varepsilon)$ 220 (3.52), 254 (2.54), 346 (1.45) nm; ${ }^{1} \mathrm{H}$ and ${ }^{13} \mathrm{C}$ NMR data, Table 1; Table 2; HRESIMS m/z 301.1067 $[\mathrm{M}+\mathrm{H}]^{+}$(calcd. for $\left.\mathrm{C}_{17} \mathrm{H}_{17} \mathrm{O}_{5}, 301.1076\right)$

(-)-Peniciphenalenin F (4): Yellowish amorphous powder $(15 \mathrm{mg}) ;[\alpha]_{\mathrm{D}}$ : $-36.10^{\circ}$ (c 0.1, MeOH); UV $(\mathrm{MeOH}) \lambda_{\max }(\log \varepsilon) 221$ (4.22), 274 (4.21), 357 (3.51), 393 (3.33) nm; ${ }^{1} \mathrm{H}$ and ${ }^{13} \mathrm{C}$ NMR data, Table 1; Table 2; HRESIMS m/z $301.1053[\mathrm{M}+\mathrm{H}]^{+}$(calcd. for $\mathrm{C}_{17} \mathrm{H}_{17} \mathrm{O}_{5}, 301.1049$ )

(+)-8-Hydroxyscleroderolide (5): Pale yellowish amorphous powder $(36 \mathrm{mg}) ;[\alpha]_{\mathrm{D}}:+65.01^{\circ}(\mathrm{c} 0.1$, $\mathrm{MeOH}) ; \mathrm{UV}(\mathrm{MeOH}) \lambda_{\max }(\log \varepsilon) 244$ (3.56), $448(1.71) \mathrm{nm} ;{ }^{1} \mathrm{H}$ and ${ }^{13} \mathrm{C}$ NMR data, Table 1; Table 2; HRESIMS $m / z 345.0967[\mathrm{M}+\mathrm{H}]^{+}$(calcd. for $\mathrm{C}_{18} \mathrm{H}_{17} \mathrm{O}_{7}, 345.0974$ ).

(-)-7,8-Dihydro-3,6-dihydroxy-1,7,7,8-tetramethyl-5H-furo-[2' ,3' :5,6]naphtho[1,8-bc]furan-5-one (6): Yellowish amorphous powder $(5 \mathrm{mg}) ;[\alpha]_{\mathrm{D}}:-36.80^{\circ}$ (c 0.1, MeOD); UV (MeOH) $\lambda_{\max }(\log \varepsilon) 226$ (1.22), 263 (3.65), 359 (3.52) nm; ${ }^{1} \mathrm{H}$ and ${ }^{13} \mathrm{C}$ NMR data, see Supplementary Information; HRESIMS $m / z$ $301.1064[\mathrm{M}+\mathrm{H}]^{+}$(calcd. for $\left.\mathrm{C}_{17} \mathrm{H}_{17} \mathrm{O}_{5}, 301.1076\right)$.

(+)-Scleroderolide (7): Yellow powder (57 mg); $[\alpha]_{\mathrm{D}}:+73.0^{\circ}$ (c 0.1, MeOD); UV (MeOH) $\lambda_{\max }(\log \varepsilon)$ 226 (3.88), 250 (2.87), 294 (1.22), 439 (2.12) nm; ${ }^{1} \mathrm{H}$ and ${ }^{13} \mathrm{C}$ NMR data, see Supplementary Information; HRESIMS m/z $329.1033[\mathrm{M}+\mathrm{H}]^{+}$(calcd. for $\mathrm{C}_{18} \mathrm{H}_{17} \mathrm{O}_{6}, 329.1039$ ).

(+)-8-Hydroxysclerodin (8): Pale yellow crystal (38 mg); $[\alpha]_{\mathrm{D}}:+66.01^{\circ}$ (c $\left.0.1, \mathrm{MeOH}\right) ; \mathrm{UV}(\mathrm{MeOH})$ $\lambda_{\max }(\log \varepsilon) 223$ (3.38), 308 (1.14), 358 (2.52) nm; ${ }^{1} \mathrm{H}$ and ${ }^{13} \mathrm{C}$ NMR data, Table 1; Table 2; HRESIMS m/z $345.0960[\mathrm{M}+\mathrm{H}]^{+}$(calcd. for $\mathrm{C}_{18} \mathrm{H}_{17} \mathrm{O}_{7}, 345.0961$ ).

Coniosclerodin (9): Pale yellow powder (8 mg); UV (MeOH) $\lambda_{\max }(\log \varepsilon) 250$ (4.12), 289 (1.14), 351 (3.52) $\mathrm{nm} ;{ }^{1} \mathrm{H}$ and ${ }^{13} \mathrm{C}$ NMR data, see Supplementary Information; HRESIMS m/z $329.1001[\mathrm{M}+\mathrm{H}]^{+}$ (calcd. for $\mathrm{C}_{18} \mathrm{H}_{17} \mathrm{O}_{6}, 329.1025$ ).

(+)-Sclerodin (10): Yellowish powder (7 mg); $[\alpha]_{\mathrm{D}}$ : $+20.01^{\circ}\left(\mathrm{c} 0.10, \mathrm{CH}_{2} \mathrm{Cl}_{2}\right)$; UV $(\mathrm{MeOH}) \lambda_{\max }(\log \varepsilon)$ 216 (3.25), 256 (4.13), 295 (1.24), 359 (3.98) nm; ${ }^{1} \mathrm{H}$ and ${ }^{13} \mathrm{C}$ NMR data, see Supplementary Information; HRESIMS $m / z 329.1015[\mathrm{M}+\mathrm{H}]^{+}$(calcd. for $\mathrm{C}_{18} \mathrm{H}_{17} \mathrm{O}_{6}, 329.1025$ ).

\subsection{X-ray Crystal Structure Analysis}

High-resolution crystallographic data for compound 8 were collected using redundant $\omega$ scans on a Rigaku XtaLabPro single-crystal diffractometer using microfocus Mo K $\alpha$ radiation and a HPAD PILATUS3 R 200K detector. Its structure was readily solved by intrinsic phasing methods (SHELXT) and by full-matrix least-squares methods on F2 using SHELX-L $[43,44]$. The 
non-hydrogen atoms were refined anisotropically, and hydrogen atoms, all identified in difference maps, were positioned geometrically and refined with $U_{\text {iso }}$ set to $x U_{\text {eq }}$ of the parent atom ( $x=1.5$ for methyl carbons or hydroxy oxygens and 1.2 for all others). Despite extremely weak anomalous signal and ambiguous Flack parameter [45] obtained with that radiation, the Bijvoet analysis using likelihood methods showed strong probabilities that this characterized enantiopure natural product is ( $R$ )-2,3,7-trihydroxy-1,8,8,9-tetramethyl-8,9-dihydro-4H,6H-benzo[de]furo[2,3-g] isochromene-4,6-dione. Duplicated measurements using a Rigaku mm007 rotating anode consolidated our statement (data not deposited).

Crystallographic data for this structure, 8, have been deposited in the Cambridge Crystallographic Data Centre database (CCDC) (deposition number CCDC 1963851). Copies of the data can be obtained free of charge from the CCDC at www.ccdc.cam.ac.uk.

Crystal data for 8: C18H16O7, $M=344.31$, Orthorhombic, a = 6.6249(2) $\AA, \mathrm{b}=10.0615(3) \AA$, $\mathrm{c}=22.5473(6) \AA \mathrm{a}=\mathrm{b}=\mathrm{g}=90^{\circ}, \mathrm{V}=1502.92(8) \AA 3 . \mathrm{O}=293(2) \mathrm{K}$, space group $P 212121, \mathrm{Z}=4, \mu(\mathrm{Mo}$ $\mathrm{K} \alpha)=0.118 \mathrm{~mm}-1,47,173$ reflections measured, 4370 independent reflections (Rint $=0.0456)$. The final R1 values were $0.0389(\mathrm{I}>2 \sigma(\mathrm{I})$ ). The final $w R(\mathrm{~F} 2)$ values were 0.1093 (all data). The goodness of fit on F2 was 1.072. Flack parameter $=-0.2(2)$. Bijvoet Pairs $=1854(100 \%$ coverage $):$ P2 $($ true $)=1.000$. P3 $($ true $)=0.987$, P3 $($ rac-twin $)=0.013$, P3 $($ false $)=0.8 \cdot 10^{-6}$. Hooft parameter $=-0.1(2)[35]$.

Supplementary Materials: The following are available online at http://www.mdpi.com/1660-3397/17/12/678/s1, S1 to S4, spectroscopic characterization of compound 1; S5 to S11, spectroscopic characterization of compounds $2+3$; S12 to S18, spectroscopic characterization of compound 4; S19 to S25, spectroscopic characterization of compound 5; S26 to S29, spectroscopic characterization of compound 6, S30 to S34, spectroscopic characterization of compound 7; S35 to S42, spectroscopic characterization of compound 8; S43 to S46, spectroscopic characterization of compound 9; S47 to S50, spectroscopic characterization of compound 10; S51 to S57, crystallographic data for compound 8; S58-S72, crystallographic data for compounds 7 and $\mathbf{1 0 .}$

Author Contributions: G.L.G. designed, managed, and implemented the microbial and chemical experiments and elucidated the structures of the reported compounds. She wrote all the technical parts of the paper. P.L. and P.V. participated in the microbial and analytical experiments; P.L. and G.A. participated in compound purification and chromatographic analysis; E.V.E. and P.R. did the crystallographic studies; J.-F.G. recorded the NMR spectra; M.W. and Y.B. collected and identified the sponge Acanthella cavernosa; N.F. reviewed and discussed the manuscript; and J.O. coordinated the work and finalized the writing and editing of the manuscript.

Funding: This work was supported and conducted in the frame of the H2020 TASCMAR project, which is funded by the European Union under grant agreement number 634674 (www.tascmar.eu).

Acknowledgments: The photos are the property of CNRS images, they were taken by Cyril Frésillon (C) Cyril Frésillon/ICSN/CNRS Photothèque). We thank the Interuniversity Institute for Marine Sciences in Eilat (IUI) for the use of the Sam Rothberg R/V and the professional assistance of its crew members. We are indebted to EcoOcean staff members for operating the ROV. We acknowledge E. Shoham and R. Liberman for their help in the field work. We thank Nicole J. de Voogd from Naturalis, Biodiversity Research Center, Leiden, the Netherlands, for taxonomic identification of the sponge. The Israel Nature and National Parks Protection Authority is acknowledged for issuing collection permits.

Conflicts of Interest: The authors declare no conflict of interest.

\section{References}

1. Kiran, G.S.; Sekar, S.; Ramasamy, P.; Thinesh, T.; Hassan, S.; Lipton, A.N.; Ninawe, A.S.; Selvin, J. Marine sponge microbial association: Towards disclosing unique symbiotic interactions. Mar. Environ. Res. 2018, 140, 169-179. [CrossRef]

2. Brinkmann, C.M.; Marker, A.; Kurtböke, I.D. An Overview on Marine Sponge-Symbiotic Bacteria as Unexhausted Sources for Natural Product Discovery. Diversity 2017, 9, 40. [CrossRef]

3. Rosenberg, E.; Sharon, G.; Atad, I.; Zilber-Rosenberg, I. The evolution of animals and plants via symbiosis with microorganisms. Environ. Microbiol. Rep. 2010, 2, 500-506. [CrossRef]

4. Hentschel, U.; Hopke, J.; Horn, M.; Friedrich, A.B.; Wagner, M.; Hacker, J.; Moore, B.S. Molecular evidence for a uniform microbial community in sponges from different oceans. Appl. Environ. Microbiol. 2002, 68, 4431-4440. [CrossRef] 
5. Taylor, M.W.; Radax, R.; Steger, D.; Wagner, M. Sponge-associated microorganisms: Evolution, ecology, and biotechnological potential. Microbiol. Mol. Biol. Rev. 2007, 71, 295-347. [CrossRef]

6. Slaby, B.M.; Hackl, T.; Horn, H.; Bayer, K.; Hentschel, U. Metagenomic binning of a marine sponge microbiome reveals unity in defense but metabolic specialization. ISME J. 2017, 11, 2465-2478. [CrossRef]

7. Sacristán-Soriano, O.; Banaigs, B.; Casamayor, E.O.; Becerro, M.A. Exploring the links between natural products and bacterial assemblages in the sponge Aplysina aerophoba. Appl. Environ. Microbiol. 2011, 77, 862-870. [CrossRef]

8. Wilson, M.C.; Mori, T.; Rückert, C.; Uria, A.R.; Helf, M.J.; Takada, K.; Gerner, C.; Steffens, U.A.; Heycke, N.; Schmitt, S.; et al. An environmental bacterial taxon with a large and distinct metabolic repertoire. Nature 2014, 506, 58-62. [CrossRef]

9. Hentschel, U.; Usher, K.M.; Taylor, M.W. Marine sponges as microbial fermenters. FEMS Microbiol. Ecol. 2006, 55, 167-177. [CrossRef]

10. Schippers, K.J.; Sipkema, D.; Osinga, R.; Smidt, H.; Pomponi, S.A.; Martens, D.E.; Wijffels, R.H. Cultivation of sponges, sponge cells and symbionts: Achievements and future prospects. Adv. Mar. Biol. 2012, 62, $273-337$.

11. Maldonado, M.; Ribes, M.; van Duyl, F.C. Nutrient fluxes through sponges: Biology, budgets, and ecological implications. Adv. Mar. Biol. 2012, 62, 113-182. [PubMed]

12. Gareth Jones, E.B.; Pang, K.-L. Marine Fungi and Fungal-Like Organisms; Walter de Gruyter: Göttingen, Germany, 2012.

13. Amend, A.; Burgaud, G.; Cunliffe, M.; Edgcomb, V.P.; Ettinger, C.L.; Gutiérrez, M.H.; Heitman, J.; Hom, E.F.Y.; Ianiri, G.; Jones, A.C.; et al. Fungi in the marine environment: Open questions and unsolved problems. MBio 2019, 10, e01189-18. [CrossRef] [PubMed]

14. Knoll, A.H. The Multiple Origins of Complex Multicellularity. Annu. Rev. Earth Planet. Sci. 2011, 39, $217-239$. [CrossRef]

15. Hardoim, C.C.; Costa, R. Microbial Communities and Bioactive Compounds in Marine Sponges of the Family Irciniidae-A Review. Mar. Drugs 2014, 12, 5089-5122. [CrossRef] [PubMed]

16. Calvo, A.M.; Cary, J.W. Association of Fungal Secondary Metabolism and Sclerotial Biology. Front. Microbiol. 2015, 6, 1-16. [CrossRef] [PubMed]

17. Cary, J.W.; Entwistle, S.; Satterlee, T.; Mack, B.M.; Gilbert, M.K.; Chang, P.K.; Scharfenstein, L.; Yin, Y.; Calvo, A.M. The Transcriptional Regulator Hbx1 Affects the Expression of Thousands of Genes in the Aflatoxin-Producing Fungus Aspergillus flavus. G3 (Bethesda) 2019, 9, 167-178. [CrossRef] [PubMed]

18. Dattenböck, C.; Tisch, D.; Schuster, A.; Monroy, A.A.; Hinterdobler, W.; Schmoll, M. Gene regulation associated with sexual development and female fertility in different isolates of Trichoderma reesei. Fungal Biol. Biotechnol. 2018, 5, 1-11. [CrossRef]

19. Le Goff, G.; Martin, M.-T.; Iorga, B.; Adelin, E.; Servy, C.; Cortial, S.; Ouazzani, J. Isolation and characterization of unusual hydrazides from Streptomyces sp. Impact of the cultivation support and extraction procedure. J. Nat. Prod. 2013, 76, 142-149. [CrossRef]

20. Adelin, E.; Martin, M.-T.; Cortial, S.; Ouazzani, J. New bioactive polyketides isolated from agar-supported fermentation of Phomopsis sp. CMU-LMA, taking advantage of the scale-up device, Platotex. Phytochemistry 2013, 93, 170-175. [CrossRef]

21. Meknaci, R.; Lopes, P.; Servy, C.; Le Caer, J.-P.; Andrieu, J.-P.; Hacène, H.; Ouazzani, J. Agar-supported cultivation of Halorubrum sp. SSR, and production of halocin C8 on the scale-up prototype Platotex. Extremophiles 2014, 18, 1049-1055. [CrossRef]

22. Adelin, E.; Slimani, N.; Cortial, S.; Schmitz-Alfonso, I.; Ouazzani, J. Platotex: An innovative and fully automated device for cell growth scale-up of agar-supported solid-state fermentation. J. Ind. Microbiol. Biotechnol. 2010, 38, 299-305. [CrossRef] [PubMed]

23. Ouazzani, J.; Sergent, D.; Cortial, S.; Lopes, P. PLATOTEX. PCT/EP2007/054834 2007.

24. Ouazzani, J.; Le Goff, G.; Felezeu, D.; Touron, A.; Allegret-Bourdon, C. UNIFERTEX, UNIversal FERmenTor EXpert. CNRS/PGT, PCT/EP2018/086882 2018.

25. Le Goff, G.; Adelin, E.; Cortial, S.; Servy, C.; Ouazzani, J. Application of solid-phase extraction to agar-supported fermentation. Bioprocess Biosyst. Eng. 2013, 36, 1285-1290. [CrossRef] [PubMed]

26. Mohanty, S.S.; Prakash, S. Effects of culture media on larvicidal property of secondary metabolites of mosquito pathogenic fungus Chrysosporium lobatum (Moniliales: Moniliaceae). Acta Tropica. 2009, 109, 50-54. [CrossRef] [PubMed] 
27. Ivanova, V.B.; Hoshino, Y.; Yazawa, K.; Ando, A.; Mikami, Y. Isolation and Structure Elucidation of Two New Antibacterial Compounds Produced by Chrysosporium queenslandicum. J. Antibiot. 2002, 55, 914-918. [CrossRef] [PubMed]

28. Van der Pyl, D.; Cans, P.; Debernard, J.J.; Herman, F.; Lelievre, Y.; Tahraoui, L.; Vuilhorgne, M.; Leboul, J. RPR113228, a novel farnesyl protein transferase inhibitor produced by Chrysosporium lobatum. J. Antibiot. 1995, 48, 736-737. [PubMed]

29. Kumar, C.G.; Mongolla, P.; Sujitha, P.; Joseph, J.; Babu, K.S.; Suresh, G.; Ramakrishna, K.V.; Purushotham, U.; Sastry, G.N.; Kamal, A. Metabolite profiling and biological activities of bioactive compounds produced by Chrysosporium lobatum strain BK-3 isolated from Kaziranga National Park, Assam, India. SpringerPlus 2013, 2 , 122-131. [CrossRef]

30. Li, Q.; Zhu, R.; Yi, W.; Chai, W.; Zhang, Z.; Lian, X.-Y. Peniciphenalenins A-F from the culture of a marine-associated fungus Penicillium sp. ZZ901. Phytochemistry 2018, 152, 53-60. [CrossRef]

31. Elsebai, M.F.; Kehraus, S.; Lindequist, U.; Sasse, F.; Shaaban, S.; Guetschow, M.; Josten, M.; Sahl, H.-G.; Koenig, G.M. Antimicrobial phenalenone derivatives from the marine-derived fungus Coniothyrium cereale. Org. Biomol. Chem. 2011, 9, 802-808. [CrossRef]

32. Ayer, W.A.; Hoyano, Y.; Pedras, M.S.; Clardy, J.; Arnold, E. Metabolites produced by the scleroderris canker fungus, Gremmeniella abietina. Part 2. The Structure of scleroderolide. Can. J. Chem. 1987, 65, 748-753. [CrossRef]

33. Ayer, W.A.; Hoyano, Y.; Pedras, M.S.; Van Altena, I. Metabolites produced by the Scleroderris canker fungus, Gremmeniella abietina. Can. J. Chem. 1986, 64, 1585-1589. [CrossRef]

34. Homma, K.; Fukuyama, K.; Katsube, Y.; Kimura, Y.; Hamasaki, T. Structure and Absolute Configuration of an Atrovenetin-like Metabolite from Aspergillus silvaticus. Agric. Biol. Chem. 1980, 44, 1333-1338. [CrossRef]

35. Hooft, R.W.W.; Straver, L.H.; Spek, A.L. Determination of absolute structure using Bayesian statistics on Bijvoet differences. J. Appl. Cryst. 2008, 41, 96-103. [CrossRef] [PubMed]

36. Gurung, S.K.; Adhikari, M.; Kim, S.W.; Bazie, S.; Kim, H.S.; Lee, H.G.; Kosol, S.; Lee, H.B.; Lee, Y.S. Discovery of Two Chrysosporium Species with Keratinolytic Activity from Field Soil in Korea. Mycobiology 2018, 46, 260-268. [CrossRef] [PubMed]

37. Dereeper, A.; Guignon, V.; Blanc, G.; Audic, S.; Buffet, S.; Chevenet, F.; Dufayard, J.F.; Guindon, S.; Lefort, V.; Lescot, M.; et al. Phylogeny.fr: Robust phylogenetic analysis for the non-specialist. Nucleic Acids Res. 2008, 36, 465-469. [CrossRef]

38. Edgar, R.C. MUSCLE: Multiple sequence alignment with high accuracy and high throughput. Nucleic Acids Res. 2004, 32, 1792-1797. [CrossRef]

39. Castresana, J. Selection of conserved blocks from multiple alignments for their use in phylogenetic analysis. Mol. Biol. Evol. 2000, 17, 540-552. [CrossRef]

40. Anisimova, M.; Gascuel, O. Approximate likelihood ratio test for branchs: A fast, accurate and powerful alternative. Syst. Biol. 2006, 55, 539-552. [CrossRef]

41. Guindon, S.; Gascuel, O. A simple, fast, and accurate algorithm to estimate large phylogenies by maximum likelihood. Syst. Biol. 2003, 52, 696-704. [CrossRef]

42. Chevenet, F.; Brun, C.; Banuls, A.L.; Jacq, B.; Chisten, R. TreeDyn: Towards dynamic graphics and annotations for analyses of trees. BMC Bioinform. 2006, 7, 439. [CrossRef]

43. Sheldrick, G.M. SHELXT-Integrated space-group and crystal-structure determination. Acta Cryst. 2015, A71, 3-8. [CrossRef]

44. Sheldrick, G.M. Crystal structure refinement with SHELXL. Acta Cryst. 2015, C71, 3-8.

45. Flack, H.D. On enantiomorph-polarity estimation. Acta Cryst. 1983, A39, 876-881. [CrossRef] 


\title{
Communication
}

\section{Genome Sequencing of Streptomyces olivaceus SCSIO T05 and Activated Production of Lobophorin CR4 via Metabolic Engineering and Genome Mining}

\author{
Chunyan Zhang ${ }^{1,2}$, Wenjuan Ding ${ }^{1,2}$, Xiangjing Qin ${ }^{1}$ and Jianhua Ju ${ }^{1,2, *}$ \\ 1 CAS Key Laboratory of Tropical Marine Bio-resources and Ecology, Guangdong Key Laboratory of Marine \\ Materia Medica, RNAM Center for Marine Microbiology, South China Sea Institute of Oceanology, \\ Chinese Academy of Sciences, 164 West Xingang Road, Guangzhou 510301, China; \\ zhchuny@foxmail.com (C.Z.); 13760785354@163.com (W.D.); xj2005qin@126.com (X.Q.) \\ 2 College of Oceanology, University of Chinese Academy of Sciences, 19 Yuquan Road, Beijing 100049, China \\ * Correspondence: jju@scsio.ac.cn; Tel./Fax: +86-20-8902-3028
}

Received: 18 September 2019; Accepted: 16 October 2019; Published: 20 October 2019

\begin{abstract}
Marine-sourced actinomycete genus Streptomyces continues to be an important source of new natural products. Here we report the complete genome sequence of deep-sea-derived Streptomyces olivaceus SCSIO T05, harboring 37 putative biosynthetic gene clusters (BGCs). A cryptic BGC for type I polyketides was activated by metabolic engineering methods, enabling the discovery of a known compound, lobophorin CR4 (1). Genome mining yielded a putative lobophorin BGC (lbp) that missed the functional FAD-dependent oxidoreductase to generate the D-kijanose, leading to the production of lobophorin $\mathrm{CR} 4$ without the attachment of D-kijanose to $\mathrm{C} 17-\mathrm{OH}$. Using the gene-disruption method, we confirmed that the $l b p$ BGC accounts for lobophorin biosynthesis. We conclude that metabolic engineering and genome mining provide an effective approach to activate cryptic BGCs.
\end{abstract}

Keywords: genome sequencing; gene disruption; lobophorin; metabolic engineering; genome mining

\section{Introduction}

Microbially produced natural products (NPs) are an important reservoir of therapeutic and agricultural agents [1]. In the previous years, quantities of new bioactive NPs were isolated from marine-derived Streptomyces strains, suggesting marine-derived Streptomyces as a predominant source of new NPs [2]. In recent years, whole-genome sequencing programs have made it clear that microorganisms have greater biosynthetic potential but are mostly underexplored by virtue that most biosynthetic gene clusters (BGCs) in a single microbial genome are normally silent. Activation of these silent BGCs contributes to new NPs discoveries. Zhang and co-workers activated a cryptic polycyclic tetramate macrolactam (PTM) BGC in Streptomyces pactum SCSIO 02999 by promoter engineering and heterologous expression [3], and also promoted the expression of a silent PKS/NRPS hybrid BGC in the same Streptomyces strain by the alteration of several regulatory genes [4]. The production of nocardamine [5] and atratumycin [6] in Streptomyces atratus SCSIO ZH16 was turned on via metabolic engineering. These genome-based studies exemplify the benefits of genome mining and metabolic engineering used for activating cryptic BGCs and discovering new bioactive NPs.

Lobophorins (Supporting Information (SI), Figure S1) belonging to a large class of spirotetronate antibiotics structurally feature a tetronate moiety spiro-linked with a cyclohexene ring, which is called pentacyclic aglycon or kijanolide [7-17]. Almost all of this class of compounds has a broad spectrum of antibacterial activities, as well as antitumor activity. Efforts to produce more spirotetronate antibiotics for drug discovery have thrived. Owing to the structural complexity of this family member, biosynthesis seems to be an effective way to afford the production of spirotetronate antibiotics, providing access to 
new analogues by pathway engineering and combinatorial biosynthetic approaches. In this paper, we report (i) the complete genome sequence of a deep-sea-derived Streptomyces olivaceus SCSIO T05, a talented strain capable of producing an array of putative NPs; (ii) activation of a cryptic lobophorin BGC $(l b p)$ by mutagenetic methods and isolation of one known spirotetronate antibiotic lobophorin CR4 (1); and (iii) identification of the lbp BGC housed in S. olivaceus SCSIO T05 by gene-disruption experiment and bioinformatics analysis.

\section{Results and Discussion}

\subsection{Genome Sequencing and Annotation of Streptomyces olivaceus SCSIO T05}

Whole genome sequence is important when analyzing the potential production of secondary metabolites [5,18]. S. olivaceus SCSIO T05, a marine-derived strain, was previously reported to be isolated from the Indian Ocean deep-sea-derived sediment [19]. Its draft genome sequence was first gained by Illumina sequencing technology, but with several gap regions. In order to estimate the biosynthetic potential of S. olivaceus SCSIO T05, the complete genome was re-sequenced and acquired by the single-molecule real-time (SMRT) sequencing technology (PacBio). A total of 67156 filtered reads with high-quality data of 432570025 bp were generated, and then they were assembled into a linear contig by the hierarchical genome assembly process (HGAP) [20]. The complete genome revealed that 8458055 base pairs constitute a linear chromosome without a plasmid, with $72.51 \%$ of GC content (Figure 1 and Table 1). Totally, 7700 protein-coding genes were predicted, along with 18 rRNA and 65 tRNA. The genome sequence of S. olivaceus SCSIO T05 was deposited in GenBank (CP043317).

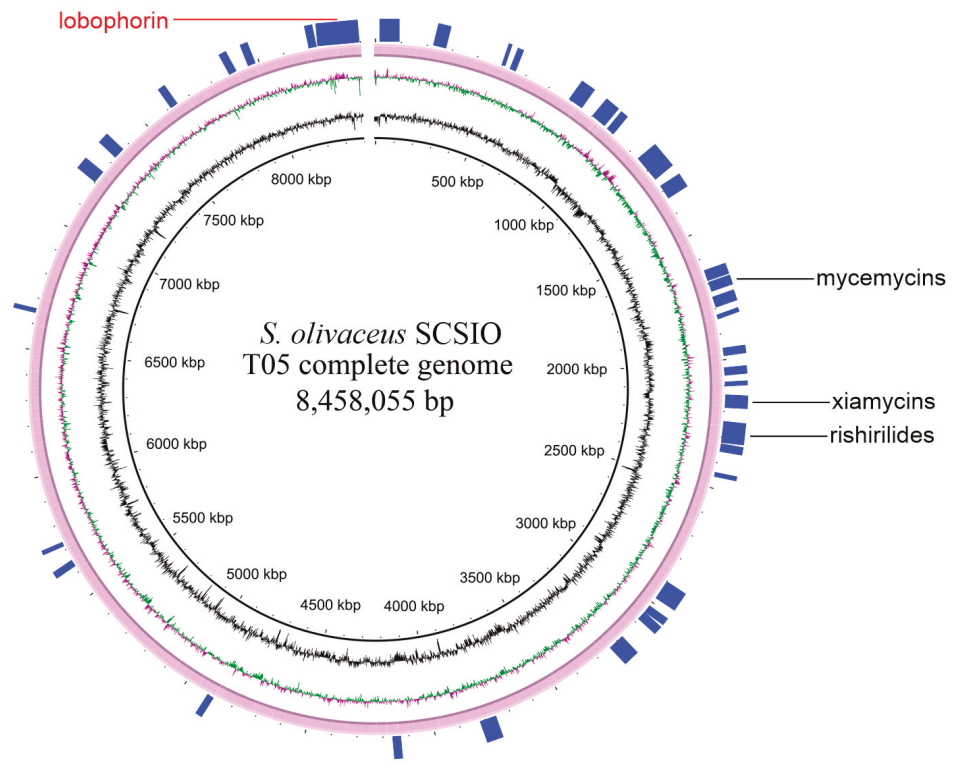

Figure 1. The complete genome of S. olivaceus SCSIO T05. The three circles (inner to outer) represent forward GC content, GC skew, and the distribution of putative biosynthetic gene clusters (BGCs) (represented by the bars) generated by antiSMASH 5.0. Clusters 18, 17, and 11 were described as rishirilides, xiamycins, and mycemycins BGCs, respectively. The putative lobophorin BGC with red color was referred to as cluster 37 . 
Table 1. Genome features of S. olivaceus SCSIO T05.

\begin{tabular}{cc}
\hline Feature & Value \\
\hline Genome size (bp) & $8,458,055$ \\
Average GC content $(\%)$ & 72.51 \\
Protein-coding genes & 7700 \\
Total size of Protein-coding genes (bp) & $7,543,173$ \\
rRNAs number & 18 \\
tRNAs number & 65 \\
\hline
\end{tabular}

AntiSMASH analysis by using antiSMASH 5.0 [21] suggested 37 BGCs within the $S$. olivaceus SCSIO T05 genome (Figure 1 and Table 2). The 37 BGCs totally occupy $1.59 \mathrm{Mb}, 18.76 \%$ of the complete genome. Most of the BGCs distribute in the two subtelomeric regions of the genome of some Streptomyces strains [18] and so do the BGCs in S. olivaceus SCSIO T05 genome. It is predicted that several BGCs are responsible for the production of polyketide- and nonribosome-peptide-derived secondary metabolites, including four PKS (Type I, Type II and Type III) and six NRPS, and six hybrid BGCs possess genes encoding more than one type of scaffold-synthesizing enzyme. Twenty-one BGCs are predicted to produce terpene, bacteriocin, lanthipeptide, or other categories. This analysis indicates that S. olivaceus SCSIO T05 is capable of producing an array of secondary metabolites, serving as a target strain for further metabolic engineering and genome mining.

Table 2. AntiSMASH-predicted BGCs for S. olivaceus SCSIO T05.

\begin{tabular}{|c|c|c|c|}
\hline \multirow{2}{*}{ BGC } & \multicolumn{2}{|c|}{ Position } & \multirow{2}{*}{ Type (Product) } \\
\hline & From & To & \\
\hline Cluster 1 & 2725 & 89768 & Type I Polyketide synthase (T1 PKS) \\
\hline Cluster 2 & 234616 & 284137 & Non-ribosomal peptide synthetase (NRPS) cluster \\
\hline Cluster 3 & 504553 & 512728 & $\begin{array}{c}\text { Bacteriocin or other unspecified ribosomally synthesized and } \\
\text { post-translationally modified peptide product (RiPP) } \\
\text { cluster (Bacteriocin) }\end{array}$ \\
\hline Cluster 4 & 525945 & 544617 & Terpene \\
\hline Cluster 5 & 793277 & 855894 & NRPS \\
\hline Cluster 6 & 901333 & 979368 & T1 PKS \\
\hline Cluster 7 & 980891 & 1005613 & Lanthipeptide cluster (Lanthipeptide) \\
\hline Cluster 8 & 1135886 & 1240760 & Other types of PKS cluster (Otherks)-NRPS \\
\hline Cluster 9 & 1275164 & 1347740 & NRPS-Terpene \\
\hline Cluster 10 & 1651711 & 1694648 & NRPS-Nucleoside cluster (Nucleoside) \\
\hline Cluster 11 & 1695020 & 1734380 & Otherks \\
\hline Cluster 12 & 1751698 & 1796277 & NRPS \\
\hline Cluster 13 & 1840051 & 1851963 & Siderophore cluster (Siderophore) \\
\hline Cluster 14 & 1967451 & 1990613 & Lanthipeptide \\
\hline Cluster 15 & 2037772 & 2059400 & Terpene \\
\hline Cluster 16 & 2090680 & 2102023 & Bacteriocin \\
\hline Cluster 17 & 2138860 & 2187226 & T1PKS-NRPS \\
\hline Cluster 18 & 2230691 & 2317060 & NRPS-Type II PKS (T2 PKS)-Otherks \\
\hline Cluster 19 & 2330735 & 2352337 & Lanthipeptide \\
\hline Cluster 20 & 2443907 & 2456009 & Siderophore \\
\hline Cluster 21 & 2905748 & 2978302 & T2 PKS \\
\hline Cluster 22 & 3029068 & 3048760 & Terpene \\
\hline Cluster 23 & 3049806 & 3075321 & Beta-lactone containing protease inhibitor (Betalactone) \\
\hline Cluster 24 & 3182776 & 3235915 & NRPS \\
\hline Cluster 25 & 3764472 & 3822515 & NRPS \\
\hline Cluster 26 & 4131410 & 4159582 & Lanthipeptide \\
\hline Cluster 27 & 4881296 & 4901736 & Phenazine cluster (Phenazine) \\
\hline
\end{tabular}


Table 2. Cont.

\begin{tabular}{cccc}
\hline \multirow{2}{*}{ BGC } & \multicolumn{2}{c}{ Position } & Type (Product) \\
\cline { 2 - 3 } & From & To & \\
\hline Cluster 28 & 5633979 & 5656500 & Lasso peptide cluster (Lassopeptide) \\
Cluster 29 & 5716930 & 5727556 & Melanin cluster (Melanin) \\
Cluster 30 & 6667385 & 6677783 & Ectoine cluster (Ectoine) \\
Cluster 31 & 7200930 & 7253804 & NRPS \\
Cluster 32 & 7328818 & 7368924 & Type III PKS (T3 PKS) \\
Cluster 33 & 7614814 & 7636052 & Aminoglycoside/aminocyclitol cluster (Amglyccycl) \\
Cluster 34 & 7882883 & 7906528 & Terpene \\
Cluster 35 & 7959695 & 7980831 & Indole cluster (Indole) \\
Cluster 36 & 8200560 & 8221618 & Terpene \\
Cluster 37 & 8239655 & 8455702 & T1pks-Nrps-T3 PKS-Oligosaccharide cluster (Oligosaccharide)-Other \\
\hline
\end{tabular}

\subsection{Activation of a Cryptic Lobophorin BGC in the Genetically Engineered Mutant}

In actuality, only a minority of potential chemicals are produced under standard laboratory culture conditions. Furthermore, the corresponding products are likely to be overlooked for multiple reasons, including low production rates, a large metabolic background, or improper culture conditions [22]. Fermented using modified-RA medium, the secondary metabolites produced by S. olivaceus SCSIO T05 were subsequently profiled using HPLC-DAD-UV. Multiple peaks were detected in the fermentation extract (Figure 2, trace i). We previously reported that five known NPs, rishirilides B (2) and C (3), lupinacidin A (4), galvaquinone B (5), and xiamycin A (6), were produced as major secondary metabolites from the wild-type strain $[19,23]$. In addition, an orphan dibenzoxazepinone biosynthetic pathway was mutagenically activated, leading to the production of new mycemycins [24], suggesting that S. olivaceus SCSIO T05 has a great potential for producing new NPs.

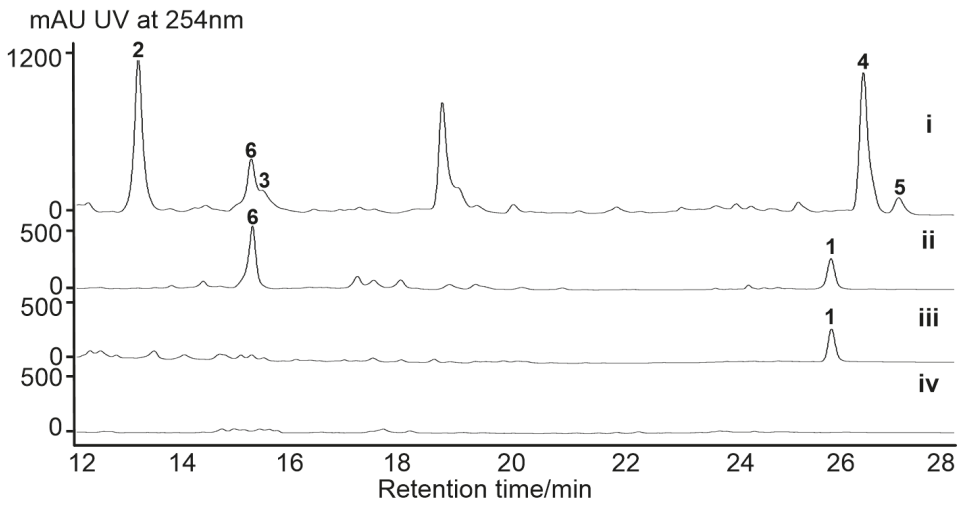

Figure 2. HPLC-based analyses of fermentation broths: (i) S. olivaceus SCSIO T05; (ii) S. olivaceus SCSIO T05R; (iii) S. olivaceus SCSIO T05RX; and (iv) S. olivaceus SCSIO T05RXL. Compound $\mathbf{1}$ is lobophorin CR4. Compounds 2-6 were previously identified as rishirilide B, rishirilide $C$, lupinacidin A, galvaquinone $\mathrm{B}$, and xiamycin A, respectively.

For exploring other secondary metabolites from the strain, S. olivaceus SCSIO T05/ $\Delta r s d K_{2}$ (S. olivaceus SCSIO T05R) was constructed to abolish the production of the anthracenes [19]. The production of the second major secondary metabolites xiamycins was accumulated, along with a new peak around 26 min, distinct from the UV absorption characteristics of xiamycins (Figure 2, trace ii). For further background elimination of xiamycins, a "double-deletion" mutant S. olivaceus SCSIO T05/ $/ r s d K_{2} / \Delta x m c P$ (S. olivaceus SCSIO T05RX) was constructed [23] in which the new peak (1) appeared to be the major product (Figure 2, trace iii). Accordingly, the S. olivaceus SCSIO T05RX mutant was fermented at a large scale, enabling the isolation and structure elucidation of this newly generated compound. 
It was identified as a known compound designated as lobophorin CR4 (Figure 3), by comparing HRESIMS, ${ }^{1} \mathrm{H}$, and ${ }^{13} \mathrm{C}$ NMR data (SI, Figures S2-S4) to the reported data of an intermediate isolated from the Streptomyces sp. SCSIO 01127/ $/$ lobG1 mutant [11]. It is reported that shifting metabolic flux of a wild-type strain by blocking the predominant product pathways may afford new secondary metabolites [5]. During our efforts to acquire new secondary metabolites by shifting the metabolic flux of marine actinomycetes $[5,23,24]$, the production of nocardamine, olimycins, and mycemycins was turned on at the expense of major products by using gene knock-out methods. Similarly, the "double-deletion" mutant (S. olivaceus SCSIO T05RX) was constructed to abolish the production of two major secondary metabolites, anthracenes and xiamycins, from the wild-type strain $[19,23]$. With the engineered shifting of S. olivaceus metabolic flux, the newly produced lobophorin CR4 was activated.

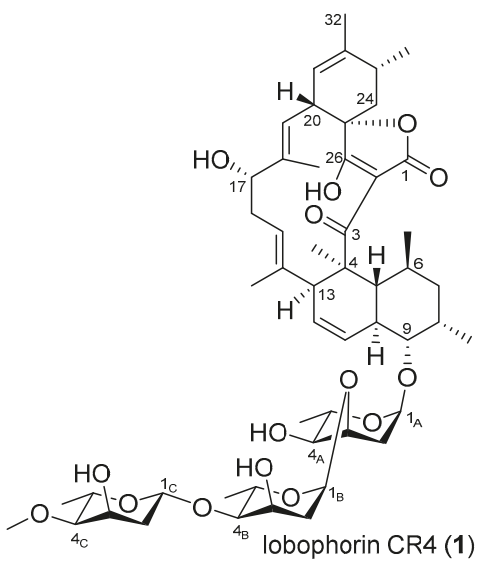

Figure 3. Structure of the isolated lobophorin CR4.

\subsection{Identification of a Putative Lobophorin (lbp) BGC via Genome Mining}

The antiSMASH analysis of the complete genome of S. olivaceus SCSIO T05 revealed a $99.1 \mathrm{~kb}$ type I PKS BGC named as lobophorin BGC (lbp), showing highly similar traits to the reported lob BGCs from Streptomyces sp. FXJ7.023 [16] and Streptomyces sp. SCSIO 01127 [11]. The complete lbp contains 38 open reading frames (ORFs). The genetic organization of $l b p$ is shown in Figure $4 \mathrm{~A}$, with genes color-coded on the basis of their proposed functions summarized in Table 3 . The nucleotide sequences were deposited in GenBank (MN396889). The $l b p$ BGC contains six inconsecutive genes lbpA1-A6, similar to lobA1-A5 in lob from S. sp. SCSIO 01127. Differently, the LobA4 homologue is separated into two polyketide synthases (PKSs), LbpA4 and LbpA5, in lbp. The high similarity between the PKS modules in $l b p$ and in $l o b$ enables us to propose that the assembly of the linear polyketide chain catalyzed by LbpA1-A6 utilizes six malonyl CoAs, six methylmalonyl-CoAs, and a 3-carbon glycerol unit (Figure 5) [11]. The $l b p$ harbors four putative regulator genes (lbpR1-R4) (Figure 4 and Table 3) that are highly similar to $l o b R 1, l o b R 3, l o b R 4$, and $l o b R 5$ in $l o b$, respectively. These four regulators are assumed to be involved in the regulation network of lobophorin CR4 biosynthesis, which seems to be less complex than lob but more complex than $k i j$ [7] and $t c a$ [8]. In contrast, five regulator genes lobR1-R5 are identified in $l o b$; three regulator genes, kijA8, kijC5, and kijD12, are included in kij; tcaR1 and tcaR2 both encode regulators in $t c a$. There is only one gene, $l b p U 2$ in $l b p$, with no apparent homologue in $l o b$ (Figure 4 and Table 3). The other genes included in $l b p$ are putatively associated with the biosynthesis of kijanose and L-digitoxose units by virtue of high similarities to corresponding counterparts in lob (Figure 4 and Table 3). 

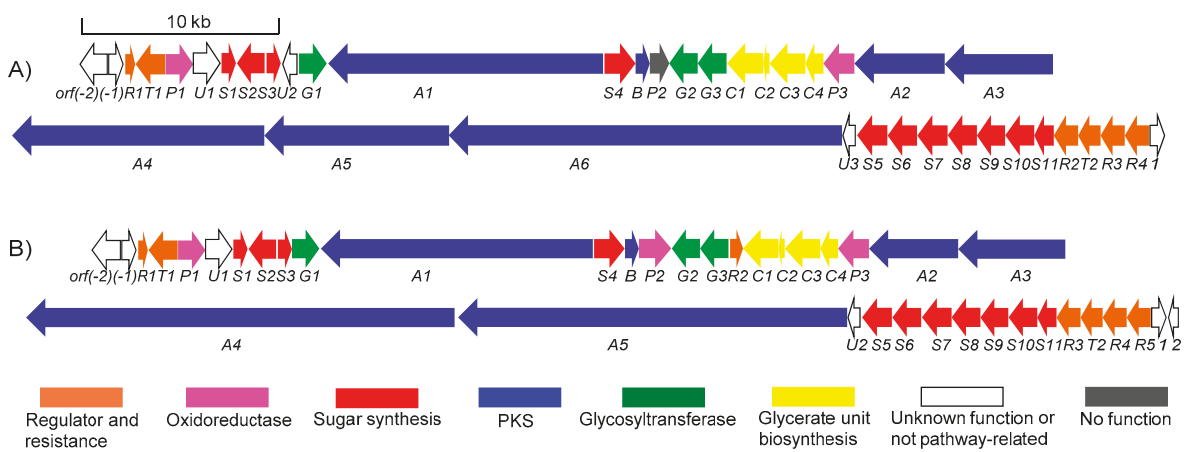

Figure 4. Genetic organizations: (A) the lbp BGC from S. olivaceus SCSIO T05; (B) the lob BGC from S. sp. SCSIO 01127.

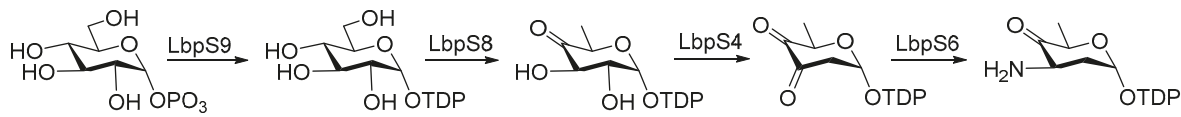
$\stackrel{\text { Lbps5 }}{\longrightarrow} \underbrace{\text { OTDP }}_{\mathrm{NH}_{2}}$<smiles>COC(=O)NC1CNC2OCC1(C)C([OH2+])O2</smiles><smiles>O=C(O)CC(=O)[Se][Se]</smiles><smiles>O=C(O)CC(=O)[Se]O[Ga][Mg][Mg]</smiles>
malonyl CoA, $5 \times \quad$ LbpB, LbpC1<smiles>CC(C(=O)O)C(=O)C(=O)O[Na]</smiles>
methylmalonyl $\mathrm{CoA}, 6 \times$<smiles>O=C(SO)[C@H](O)CO</smiles>
3-carbon glycerol unit

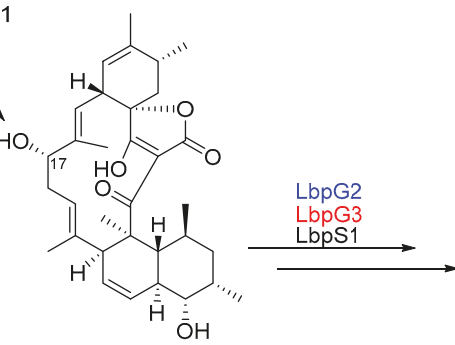

LBP aglycon

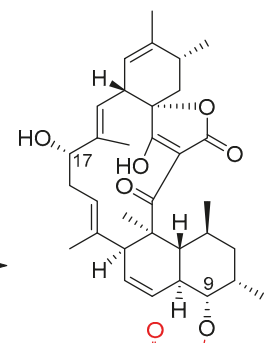

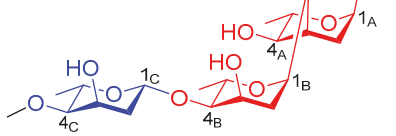

Figure 5. Proposed biosynthetic pathway of lobophorin CR4. 
Table 3. Deduced function of open reading frames (ORFs) in the lbp BGC.

\begin{tabular}{|c|c|c|c|c|}
\hline ORF & Size $^{a}$ & Proposed Function & ID/SI ${ }^{b}$ & Protein Homologue and Origin \\
\hline $\operatorname{orf}(-2)$ & 374 & macrolide glycosyltransferase & $100 / 100$ & $\begin{array}{l}\text { Orf(-2) (AGI99472.1); Streptomyces sp. } \\
\text { SCSIO 01127 }\end{array}$ \\
\hline $\operatorname{orf}(-1)$ & 260 & FkbM family methyltransferase & $100 / 100$ & $\begin{array}{l}\text { Orf(-1) (AGI99473.1); Streptomyces sp. } \\
\text { SCSIO 01127 }\end{array}$ \\
\hline$l b p R 1$ & 195 & TetR type regulatory protein & $100 / 100$ & $\begin{array}{l}\text { lobR1 (AGI99474.1); Streptomyces sp. } \\
\text { SCSIO 01127 }\end{array}$ \\
\hline lbpT1 & 497 & efflux permease & $100 / 100$ & $\begin{array}{l}\text { lobT1 (AGI99475.1); Streptomyces sp. } \\
\text { SCSIO 01127 }\end{array}$ \\
\hline lbpP1 & 392 & p450 monooxygenase & $100 / 100$ & $\begin{array}{l}\text { lobP1 (AGI99476.1); Streptomyces sp. } \\
\text { SCSIO 01127 }\end{array}$ \\
\hline lbpu1 & 326 & aldo/keto reductase & $100 / 100$ & $\begin{array}{l}\text { lobU1 (AGI99477.1); Streptomyces sp. } \\
\text { SCSIO 01127 }\end{array}$ \\
\hline lbpS1 & 271 & sugar-O-methyltransferase & $99 / 100$ & $\begin{array}{l}\text { lobS1 (AGI99478.1); Streptomyces sp. } \\
\text { SCSIO 01127 }\end{array}$ \\
\hline lbpS2 & 384 & sugar 4-aminotransferase & $100 / 100$ & $\begin{array}{l}\text { lobS2 (AGI99479.1); Streptomyces sp. } \\
\text { SCSIO 01127 }\end{array}$ \\
\hline lbpS3 & 201 & SAM-dependent methyltransferase & $97 / 98$ & $\begin{array}{l}\text { lobS3 (AGI99480.1); Streptomyces sp. } \\
\text { SCSIO 01127 }\end{array}$ \\
\hline lbpU2 & 197 & hypothetical protein & $100 / 100$ & $\begin{array}{l}\text { hypothetical protein (KMB22099.1); } \\
\text { Klebsiella pneumoniae }\end{array}$ \\
\hline$l b p G 1$ & 391 & glycosyltransferase & $100 / 100$ & $\begin{array}{l}\text { lobG1 (AGI99481.1); Streptomyces sp. } \\
\text { SCSIO 01127 }\end{array}$ \\
\hline$l b p A 1$ & 3936 & $\begin{array}{c}\text { PKS } \\
\text { (KS-AT-DH-ER-KR-ACP-KS-AT-DH-KR-ACP) }\end{array}$ & $100 / 100$ & $\begin{array}{l}\text { lobA1 (AGI99482.1); Streptomyces sp. } \\
\text { SCSIO } 01127\end{array}$ \\
\hline $\operatorname{lbpS4}$ & 483 & sugar 2,3-dehydratase & $100 / 100$ & $\begin{array}{l}\text { lobS4 (AGI99483.1); Streptomyces sp. } \\
\text { SCSIO 01127 }\end{array}$ \\
\hline $\operatorname{lbp} B$ & 253 & thioesterase & $100 / 100$ & $\begin{array}{l}\text { lobB (AGI99484.1); Streptomyces sp. } \\
\text { SCSIO } 01127\end{array}$ \\
\hline lbpP2 & 313 & FAD-dependent oxidoreductase & $100 / 100$ & $\begin{array}{l}\text { part of lobP2 (AGI99485.1); Streptomyces sp. } \\
\text { SCSIO 01127 }\end{array}$ \\
\hline$l b p G 2$ & 416 & glycosyltransferase & $99 / 100$ & $\begin{array}{l}\text { lobG2 (AGI99486.1); Streptomyces sp. } \\
\text { SCSIO 01127 }\end{array}$ \\
\hline$l b p G 3$ & 476 & glycosyltransferase & $99 / 100$ & $\begin{array}{l}\text { lobG3 (AGI99487.1); Streptomyces sp. } \\
\text { SCSIO 01127 }\end{array}$ \\
\hline $\operatorname{lbp} C 1$ & 680 & hydrolase superfamily dihydrolipo-amide acyltransferase-like protein & 99/99 & $\begin{array}{l}\text { lobC1 (AGI99489.1); Streptomyces sp. } \\
\text { SCSIO 01127 }\end{array}$ \\
\hline $\operatorname{lbp} C 2$ & 75 & $\mathrm{ACP}$ & $99 / 100$ & $\begin{array}{l}\text { lobC2 (AGI99490.1); Streptomyces sp. } \\
\text { SCSIO 01127 }\end{array}$ \\
\hline $\operatorname{lbpC3}$ & 621 & FkbH-like protein & $99 / 100$ & $\begin{array}{l}\text { lobC3 (AGI99491.1); Streptomyces sp. } \\
\text { SCSIO 01127 }\end{array}$ \\
\hline $\operatorname{lbpC4}$ & 342 & ketoacyl acyl carrier protein synthase III & $100 / 100$ & $\begin{array}{l}\text { lobC4 (AGI99492.1); Streptomyces sp. } \\
\text { SCSIO 01127 }\end{array}$ \\
\hline lbpP3 & 492 & FAD-dependent oxidoreductase & $100 / 100$ & $\begin{array}{l}\text { lobP3 (AGI99493.1); Streptomyces sp. } \\
\text { SCSIO 01127 }\end{array}$ \\
\hline $\operatorname{lbp} A 2$ & 1573 & $\begin{array}{c}\text { PKS } \\
\text { (KS-AT-KR-ACP) }\end{array}$ & $99 / 100$ & $\begin{array}{l}\text { lobA2 (AGI99494.1); Streptomyces sp. } \\
\text { SCSIO 01127 }\end{array}$ \\
\hline $\operatorname{lbp} A 3$ & 1798 & $\begin{array}{c}\text { PKS } \\
\text { (KS-AT-DH-KR-ACP) }\end{array}$ & $99 / 99$ & $\begin{array}{l}\text { lobA3 (AGI99495.1); Streptomyces sp. } \\
\text { SCSIO 01127 }\end{array}$ \\
\hline $\operatorname{lbp} A 4$ & 4376 & $\begin{array}{c}\text { PKS } \\
\text { (KR-ACP-KS-AT-DH-KR-ACP-KS-AT-DH-KR-ACP) }\end{array}$ & $100 / 100$ & $\begin{array}{l}\text { part of lobA4 (AGI99496.1); Streptomyces sp. } \\
\text { SCSIO 01127 }\end{array}$ \\
\hline lbpA5 & 2881 & $\begin{array}{c}\text { PKS } \\
\text { (KS-AT-DH-KR-ACP-KS-AT-DH) }\end{array}$ & $99 / 98$ & $\begin{array}{l}\text { part of lobA4 (AGI99496.1); Streptomyces sp. } \\
\text { SCSIO 01127 }\end{array}$ \\
\hline$l b p A 6$ & 6362 & $\begin{array}{c}\text { PKS } \\
\text { (KS-AT-ACP-KS-AT-DH-KR-ACP-KS-AT-DH-KR-ACP-KS-AT-DH-KR-ACP) }\end{array}$ & 99/99 & $\begin{array}{l}\text { lobA5 (AGI99497.1); Streptomyces sp. } \\
\text { SCSIO 01127 }\end{array}$ \\
\hline lbpu3 & 151 & 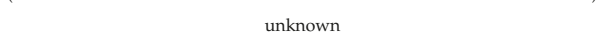 & $100 / 100$ & $\begin{array}{l}\text { lobU2 (AGI99498.1); Streptomyces sp. } \\
\text { SCSIO 01127 }\end{array}$ \\
\hline lbpS5 & 414 & sugar 3-C-methyl transferase & $100 / 100$ & $\begin{array}{l}\text { lobS5 (AGI99499.1); Streptomyces sp. } \\
\text { SCSIO } 01127\end{array}$ \\
\hline lbpS6 & 373 & sugar 3-aminotransferase & $100 / 100$ & $\begin{array}{l}\text { lobS6 (AGI99500.1); Streptomyces sp. } \\
\text { SCSIO } 01127\end{array}$ \\
\hline lbpS7 & 439 & acyl-CoA dehydrogenase & $100 / 100$ & $\begin{array}{l}\text { lobS7 (AGI99501.1); Streptomyces sp. } \\
\text { SCSIO } 01127\end{array}$ \\
\hline lbpS8 & 341 & sugar 4,6-dehydratase & $100 / 100$ & $\begin{array}{l}\text { lobS8 (AGI99502.1); Streptomyces sp. } \\
\text { SCSIO } 01127\end{array}$ \\
\hline lbpS9 & 298 & sugar nucleotidyltransferase & $99 / 100$ & $\begin{array}{l}\text { lobS9 (AGI99503.1); Streptomyces sp. } \\
\text { SCSIO 01127 }\end{array}$ \\
\hline lbpS10 & 332 & sugar 3-ketoreductase & $100 / 100$ & $\begin{array}{l}\text { lobS10 (AGI99504.1); Streptomyces sp. } \\
\text { SCSIO 01127 }\end{array}$ \\
\hline lbpS11 & 202 & sugar 5-epimerase & $99 / 100$ & $\begin{array}{l}\text { lobS11 (AGI99505.1); Streptomyces sp. } \\
\text { SCSIO 01127 }\end{array}$ \\
\hline$l b p R 2$ & 274 & TetR type regulatory protein & $99 / 100$ & $\begin{array}{l}\text { lobR3 (AGI99506.1); Streptomyces sp. } \\
\text { SCSIO 01127 }\end{array}$ \\
\hline $\operatorname{lbp} T 2$ & 211 & forkhead-associated protein & $99 / 100$ & $\begin{array}{l}\text { lobT2 (AGI99507.1); Streptomyces sp. } \\
\text { SCSIO 01127 }\end{array}$ \\
\hline lbpR3 & 298 & putative regulatory protein & $99 / 100$ & $\begin{array}{l}\text { lobR4 (AGI99508.1); Streptomyces sp. } \\
\text { SCSIO 01127 }\end{array}$ \\
\hline $\operatorname{lbpR4}$ & 309 & LysR family transcriptional regulator & $99 / 100$ & $\begin{array}{l}\text { lobR5 (AGI99509.1); Streptomyces sp. } \\
\text { SCSIO 01127 }\end{array}$ \\
\hline orf1 & 183 & acetyltransferase & $100 / 100$ & $\begin{array}{l}\text { Orf1 (AGI99510.1); Streptomyces sp. } \\
\text { SCSIO } 01127\end{array}$ \\
\hline
\end{tabular}

${ }^{\mathrm{a}}$ Amino acids. ${ }^{\mathrm{b}}$ Identity/similarity. 
To demonstrate the validity of the putative $l b p$ BGC, $l b p C 4$ coding for ketosynthase-III-like protein, which incorporates a 3-carbon glycerol unit into the biosynthetic precursor LOB aglycon [11], was disrupted by using PCR-targeting methods. As expected, the production of lobophorin CR4 was completely blocked in S. olivaceus SCSIO T05/ $\Delta r s d K_{2} / \Delta x m c P / \Delta l b p C 4$ (S. olivaceus SCSIO T05RXL) (Figure 2, trace iv), demonstrating that the lbp BGC is indeed responsible for lobophorin biosynthesis. With high similarity to the lob BGC, the lbp BGC accounts for lobophorin CR4 without the attachment of kijanose to $\mathrm{C} 17-\mathrm{OH}$, rather than lobophorins $\mathrm{A}$ and $\mathrm{B}$ in lob. Based on bioinformatics analysis, a series of enzymes are proposed to be involved in kijanose biosynthesis (Figure 5) [7]. Among them, the amino acid sequence of the putative FAD-dependent oxidoreductase LbpP2 is far shorter than its homologues LobP2 [11] and KijB3 [7]. KijB3 is proposed to oxidize the methyl group to a carboxylate group, essential for the generation of the kijanose moiety [7]. Multiple protein sequence alignments of $\mathrm{LbpP} 2$, LobP2, and KijB3 revealed that the conserved FAD binding domain is missing in LbpP2 (Figure S5). Thus, we speculate that LbpP2 is nonfunctional, failing to catalyze the carboxylation and hinder the generation of kijanose.

Given the high similarity of LbpG3 and LobG3, we envision that LbpG3 has a similar function as LobG3, a glycosyltransferase from S. sp. SCSIO 01127, tandemly attaching the first two L-digitoxose at C-9 in lobophorins [11]. LbpG2 has 99\% similarity to LobG2, another glycosyltransferase from the same strain, which was established to transfer the terminal L-digitoxose [11]. Both LbpG2 and LbpG3 are likely to be involved in the transfers of three sugar units, sugars A, B, and C, in lobophorin CR4 (Figure 5), consistent with the metabolite profile of $\Delta$ lobG1 in S. sp. SCSIO 01127 [11].

\section{Experimental Section}

\subsection{General Experimental Procedures}

The plasmids and bacteria used are listed in Table S1. Streptomyces olivaceus SCSIO T05 and its mutants were incubated on modified ISP-4 medium [25] with 3\% sea salt and fermented in modified RA medium [19]. All cultures for Streptomyces were incubated at $28^{\circ} \mathrm{C}$. Luria-Bertani (LB) medium was used for E. coli, with appropriate antibiotics added at a final concentration of $100 \mu \mathrm{g} / \mathrm{mL}$ of ampicillin (Amp), $50 \mu \mathrm{g} / \mathrm{mL}$ of kanamycin (Kan), $50 \mu \mathrm{g} / \mathrm{mL}$ of apramycin (Apr), $25 \mu \mathrm{g} / \mathrm{mL}$ of chloroamphenicol (Cml), and $50 \mu \mathrm{g} / \mathrm{mL}$ of trimethoprim (TMP).

A 1260 infinity system (Agilent, Santa Clara, CA, USA), which uses a Phenomenex Prodigy ODS (2) column $(150 \times 4.6 \mathrm{~mm}, 5 \mu \mathrm{m}$, USA), was used for HPLC-based analyses. Silica gel with the size of 100-200 mesh (Jiangpeng Silica gel development, Inc., Shandong, China) was used for column chromatography (CC). A Primaide 1110 solvent delivery module, which is equipped with a 1430 photodiode array detector (Hitachi, Tokyo, Japan) and uses a YMC-Pack ODS-A column $(250 \mathrm{~mm}$ $\times 10 \mathrm{~mm}, 5 \mu \mathrm{m}$ ), was used for semi-preparative HPLC. A MaXis Q-TOF mass spectrometer (Bruker, Billerica, MA, USA) was used to acquire high-resolution mass spectral data. An MCP-500 polarimeter (Anton Paar, Graz, Austria) was used to record optical rotations. A Bruker Avance 500 was used to record NMR spectra. Carbon signals and the residual proton signals of DMSO- $d_{6}$ were used for calibration $\left(\delta_{\mathrm{C}} 39.52\right.$ and $\left.\delta_{\mathrm{H}} 2.50\right)$.

\subsection{Genome Sequencing and Bioinformatic Analysis}

Whole genome scanning and annotation of S. olivaceus SCSIO T05 were acquired by the single-molecule real-time (SMRT) sequencing technology (PacBio) at Shanghai Majorbio Bio-Pharm Technology Co., Ltd (Shanghai, China). AntiSMASH (AntiSMASH 5.0, available at http://antismash. secondarymetabolites.org/) was used to analyze and assess the potential BGCs. FramePlot (FramePlot 4.0 beta, available at http://nocardia.nih.go.jp/fp4/) was used to analyze ORFs whose functions were predicted based on an online BLAST program (http://blast.ncbi.nlm.nih.gov/). 


\subsection{Construction of a "Triple-Deletion" Mutant Strain}

Gene $l b p C 4$ from the $l b p$ BGC was inactivated by the REDIRECT protocol [26]. All primers used in this study are listed in Table S2. LbpC4 was replaced by the apramycin resistance gene oriT/aac(3)IV fragment in the target cosmids 01-07D or 21-02E. The target mutant clones, S. olivaceus SCSIO T05RXL, were accomplished as previously described $[19,23,24]$.

\subsection{Fermentation and HPLC-based Analyses of S. olivaceus SCSIO T05 and Its Mutants}

The Streptomyces used in this study were incubated in modified ISP-4 medium plates for 2-3 d. For fermentation, a portion of mycelium and spores was seeded into $50 \mathrm{~mL}$ of modified RA medium in a $250 \mathrm{~mL}$ flask and then shaken at $200 \mathrm{rpm}$ and $28^{\circ} \mathrm{C}$ for $8 \mathrm{~d}$. The cultures were extracted with an equal volume of butanone. Organic phases were then dissolved in $\mathrm{CH}_{3} \mathrm{OH}(1 \mathrm{~mL})$ after having been evaporated to dryness, and $40 \mu \mathrm{L}$ of each relevant sample was injected for HPLC-based analysis. The UV detection was at $254 \mathrm{~nm}$. Solvent $\mathrm{A}$ is composed of $85 \% \mathrm{ddH}_{2} \mathrm{O}$ and $15 \% \mathrm{CH}_{3} \mathrm{CN}$, supplemented with $0.1 \%$ HOAc. Solvent B is composed of $85 \% \mathrm{CH}_{3} \mathrm{CN}$ and $15 \% \mathrm{ddH}_{2} \mathrm{O}$, supplemented with $0.1 \%$ HOAc. Samples were analyzed via the following method: a linear gradient from $0 \%$ to $80 \%$ solvent $\mathrm{B}$ in $20 \mathrm{~min}$, and then, from $80 \%$ to $100 \%$ solvent B for $1.5 \mathrm{~min}$, finally eluted with $100 \%$ solvent B in $6.5 \mathrm{~min}$. The flow rate was $1.0 \mathrm{~mL} / \mathrm{min}$.

\subsection{Production, Isolation, and Structure Elucidation of Lobophorin CR4}

The mycelium of $S$. olivaceus SCSIO T05RX were inoculated into $50 \mathrm{~mL}$ of modified-RA medium and then shaken at $200 \mathrm{rpm}$ and $28^{\circ} \mathrm{C}$ for $2 \mathrm{~d}$, to gain the seed cultures. After that, the seed cultures were transferred into $150 \mathrm{~mL}$ of modified-RA medium and shaken at $200 \mathrm{rpm}$ and $28^{\circ} \mathrm{C}$ for $8 \mathrm{~d}$. After the large-scale fermentation was accomplished, a total of $12 \mathrm{~L}$ of the growth culture was centrifuged at $4000 \mathrm{~g}$ for $10 \mathrm{~min}$ to separate the supernatant and mycelium and further extracted by butanone and acetone, respectively. The two organic phases were concentrated (via solvent removal under vacuum), and the residues were combined. The combined sample was subjected to normal phase silica gel CC eluted with $\mathrm{CHCl}_{3}-\mathrm{CH}_{3} \mathrm{OH}$ (100:0, 98:2, 96:4, 94:6, 92:8, 90:10, 85:15, 80:20, 70:30, 50:50, v/v, each solvent combination in $250 \mathrm{~mL}$ volume) to give ten fractions (AFr.1-AFr.10). Fractions A1-A3 were purified to afford the accumulation of compound $\mathbf{1}(98 \mathrm{mg})$, by preparative HPLC, eluting with $90 \%$ solvent B (A: $\mathrm{H}_{2} \mathrm{O} ; \mathrm{B}: \mathrm{CH}_{3} \mathrm{CN}$ ) over the course of $30 \mathrm{~min}$. The flowrate was $2.5 \mathrm{~mL} / \mathrm{min}$ and the UV detection was at $254 \mathrm{~nm}$. The purified compound was subjected to $\mathrm{MS},{ }^{1} \mathrm{H}$, and ${ }^{13} \mathrm{C}$ NMR spectra measurements and elucidated as a known intermediate 3 during lobophorins A and B biosynthesis [11], and we named it lobophorin CR4 (1).

\section{Conclusions}

In this study, we acquired the complete genome sequence of S. olivaceus SCSIO T05. The biosynthetically talented strain harbors 37 putative BGCs analyzed by antiSMASH. To explore the biosynthetic potential of this strain, metabolic engineering and genome mining were performed. The major anthracenes and indolosesquiterpenes biosynthetic pathways were blocked, and an orphan spirotetronate antibiotics BGC (lbp) was activated in S. olivaceus SCSIO T05, leading to the isolation and identification of one known compound, lobophorin CR4. We have identified the $l b p$ BGC accounting for lobophorin biosynthesis by gene-disruption experiments and bioinformatics analysis. The production of lobophorin CR4 without the attachment of D-kijanose to C17-OH was on account that the nonfunctional FAD-dependent oxidoreductase LbpP2 failed to generate D-kijanose. This work highlights that metabolic engineering and genome mining are the effective ways to turn on putative orphan or silent BGCs to acquire new NPs for drugs discovery.

Supplementary Materials: The following are available online at http://www.mdpi.com/1660-3397/17/10/593/s1. This section includes HRESIMS, 1D NMR spectra for compound 1, construction of $\Delta l b p C 4$. 
Author Contributions: C.Z. performed the experiments and wrote the draft manuscript. W.D. performed the isolation of compound 1. X.Q. helped to perform the sequence alignments. J.J. supervised the whole work and edited the manuscript. All authors read and approved the final manuscript.

Funding: This research was funded by the National Natural Science Foundation of China (81425022, U1706206, and U1501223), and Natural Science Foundation of Guangdong Province (2016A030312014).

Acknowledgments: We are grateful to Aijun Sun, Xiaohong Zheng, Yun Zhang, Xuan Ma, and Zhihui Xiao, in the analytical facility center of the SCSIO for recording MS and NMR data.

Conflicts of Interest: The authors declare no conflicts of interest.

\section{References}

1. Berdy, J. Bioactive microbial metabolites. J. Antibiot. 2005, 58, 1-26. [CrossRef] [PubMed]

2. Carroll, A.R.; Copp, B.R.; Davis, R.A.; Keyzers, R.A.; Prinsep, M.R. Marine natural products. Nat. Prod. Rep. 2019, 36, 122-173. [CrossRef] [PubMed]

3. Saha, S.; Zhang, W.; Zhang, G.; Zhu, Y.; Chen, Y.; Liu, W.; Yuan, C.; Zhang, Q.; Zhang, H.; Zhang, L.; et al. Activation and characterization of a cryptic gene cluster reveals a cyclization cascade for polycyclic tetramate macrolactams. Chem. Sci. 2017, 8, 1607-1612. [CrossRef] [PubMed]

4. Chen, R.; Zhang, Q.; Tan, B.; Zheng, L.; Li, H.; Zhu, Y.; Zhang, C. Genome Mining and Activation of a Silent PKS/NRPS Gene Cluster Direct the Production of Totopotensamides. Org. Lett. 2017, 19, 5697-5700. [CrossRef]

5. Li, Y.; Zhang, C.; Liu, C.; Ju, J.; Ma, J. Genome sequencing of Streptomyces atratus SCSIO ZH16 and activation production of nocardamine via metabolic engineering. Front. Microbiol. 2018, 9, 1269. [CrossRef]

6. Sun, C.; Yang, Z.; Zhang, C.; Liu, Z.; He, J.; Liu, Q.; Zhang, T.; Ju, J.; Ma, J. Genome Mining of Streptomyces atratus SCSIO ZH16: Discovery of Atratumycin and Identification of Its Biosynthetic Gene Cluster. Org. Lett. 2019, 21, 1453-1457. [CrossRef]

7. Zhang, H.; White-Phillip, J.A.; Melançon, C.E.; Kwon, H.J.; Yu, W.L.; Liu, H.W. Elucidation of the Kijanimicin Gene Cluster: Insights into the Biosynthesis of Spirotetronate Antibiotics and Nitrosugars. J. Am. Chem. Soc. 2007, 129, 14670-14683. [CrossRef]

8. Fang, J.; Zhang, Y.; Huang, L.; Jia, X.; Zhang, Q.; Zhang, X.; Tang, G.; Liu, W. Cloning and Characterization of the Tetrocarcin A Gene Cluster from Micromonospora chalcea NRRL 11289 Reveals a Highly Conserved Strategy for Tetronate Biosynthesis in Spirotetronate Antibiotics. J. Bacteriol. 2008, 190, 6014-6025. [CrossRef]

9. Wei, R.B.; Xi, T.; Li, J.; Wang, P.; Li, F.C.; Lin, Y.C.; Qin, S. Lobophorin C and D, New Kijanimicin Derivatives from a Marine Sponge-Associated Actinomycetal Strain AZS17. Mar. Drugs 2011, 9, 359-368. [CrossRef]

10. Niu, S.; Li, S.; Chen, Y.; Tian, X.; Zhang, H.; Zhang, G.; Zhang, W.; Yang, X.; Zhang, S.; Ju, J.; et al. Lobophorins $\mathrm{E}$ and F, new spirotetronate antibiotics from a South China Sea-derived Streptomyces sp. SCSIO 01127. J. Antibiolt. 2011, 64, 711. [CrossRef]

11. Li, S.; Xiao, J.; Zhu, Y.; Zhang, G.; Yang, C.; Zhang, H.; Ma, L.; Zhang, C. Dissecting Glycosylation Steps in Lobophorin Biosynthesis Implies an Iterative Glycosyltransferase. Org. Lett. 2013, 15, 1374-1377. [CrossRef] [PubMed]

12. Pan, H.Q.; Zhang, S.Y.; Wang, N.; Li, Z.L.; Hua, H.M.; Hu, J.C.; Wang, S.J. New Spirotetronate Antibiotics, Lobophorins H and I, from a South China Sea-Derived Streptomyces sp. 12A35. Mar. Drugs 2013, 11, 3891-3901. [CrossRef] [PubMed]

13. Chen, C.; Wang, J.; Guo, H.; Hou, W.; Yang, N.; Ren, B.; Liu, M.; Dai, H.; Liu, X.; Song, F.; et al. Three antimycobacterial metabolites identified from a marine-derived Streptomyces sp. MS100061. Appl. Microbiol. Biotechnol. 2013, 97, 3885-3892. [CrossRef] [PubMed]

14. Cruz, P.G.; Fribley, A.M.; Miller, J.R.; Larsen, M.J.; Schultz, P.J.; Jacob, R.T.; Tamayo-Castillo, G.; Kaufman, R.J.; Sherman, D.H. Novel Lobophorins Inhibit Oral Cancer Cell Growth and Induce Atf4- and Chop-Dependent Cell Death in Murine Fibroblasts. ACS Med. Chem. Lett. 2015, 6, 877-881. [CrossRef] [PubMed]

15. Song, C.; Pan, H.; Hu, J. Isolation and identification of a new antibiotic, lobophorin J, from a deep sea-derived Streptomyces sp. 12A35. Chin. J. Antibiot. 2015, 40, 721-727.

16. Yue, C.; Niu, J.; Liu, N.; Lü, Y.; Liu, M.; Li, Y. Cloning and identification of the lobophorin biosynthetic gene cluster from marine Streptomyces olivaceus strain FXJ7.023. Pak. J. Pharm. Sci. 2016, 29, 287-293. [PubMed] 
17. Braña, A.; Sarmiento-Vizcaíno, A.; Osset, M.; Pérez-Victoria, I.; Martín, J.; de Pedro, N.; de la Cruz, M.; Díaz, C.; Vicente, F.; Reyes, F.; et al. Lobophorin K, a new natural product with cytotoxic activity produced by Streptomyces sp. M-207 associated with the deep-sea coral Lophelia pertusa. Mar. Drugs. 2017, 15, 144. [CrossRef]

18. Low, Z.J.; Pang, L.M.; Ding, Y.; Cheang, Q.W.; Hoang, K.L.M.; Tran, H.T.; Li, J.; Liu, X.-W.; Kanagasundaram, Y.; Yang, L.; et al. Identification of a biosynthetic gene cluster for the polyene macrolactam sceliphrolactam in a Streptomyces strain isolated from mangrove sediment. Sci. Rep. 2018, 8, 1594. [CrossRef]

19. Zhang, C.; Sun, C.; Huang, H.; Gui, C.; Wang, L.; Li, Q.; Ju, J. Biosynthetic Baeyer-Villiger Chemistry Enables Access to Two Anthracene Scaffolds from a Single Gene Cluster in Deep-Sea-Derived Streptomyces olivaceus SCSIO T05. J. Nat. Prod. 2018, 81, 1570-1577. [CrossRef]

20. Chin, C.-S.; Alexander, D.H.; Marks, P.; Klammer, A.A.; Drake, J.; Heiner, C.; Clum, A.; Copeland, A.; Huddleston, J.; Eichler, E.E.; et al. Nonhybrid, finished microbial genome assemblies from long-read SMRT sequencing data. Nat. Methods 2013, 10, 563-569. [CrossRef]

21. Blin, K.; Shaw, S.; Steinke, K.; Villebro, R.; Ziemert, N.; Lee, S.Y.; Medema, M.H.; Weber, T. AntiSMASH 5.0: Updates to the secondary metabolite genome mining pipeline. Nucleic Acids Res. 2019, 47, W81-W87. [CrossRef] [PubMed]

22. Scherlach, K.; Hertweck, C. Triggering cryptic natural product biosynthesis in microorganisms. Org. Biomol. Chem. 2009, 7, 1753. [CrossRef] [PubMed]

23. Sun, C.; Zhang, C.; Qin, X.; Wei, X.; Liu, Q.; Li, Q.; Ju, J. Genome mining of Streptomyces olivaceus SCSIO T05: Discovery of olimycins A and B and assignment of absolute configurations. Tetrahedron 2018, 74, 199-203. [CrossRef]

24. Zhang, C.; Yang, Z.; Qin, X.; Ma, J.; Sun, C.; Huang, H.; Li, Q.; Ju, J. Genome Mining for Mycemycin: Discovery and Elucidation of Related Methylation and Chlorination Biosynthetic Chemistries. Org. Lett. 2018, 20, 7633-7636. [CrossRef] [PubMed]

25. Liu, W.; Shen, B. Genes for Production of the Enediyne Antitumor Antibiotic C-1027 in Streptomyces globisporus Are Clustered with the cagA Gene That Encodes the C-1027 Apoprotein. Antimicrob. Agents Chemother. 2000, 44, 382-392. [CrossRef] [PubMed]

26. Gust, B.; Challis, G.L.; Fowler, K.; Kieser, T.; Chater, K.F. PCR-targeted Streptomyces gene replacement identifies a protein domain needed for biosynthesis of the sesquiterpene soil odor geosmin. Proc. Natl. Acad. Sci. USA 2003, 100, 1541-1546. [CrossRef] [PubMed]

(C) 2019 by the authors. Licensee MDPI, Basel, Switzerland. This article is an open access article distributed under the terms and conditions of the Creative Commons Attribution (CC BY) license (http://creativecommons.org/licenses/by/4.0/). 



\title{
Article \\ Polyketides from the Mangrove-Derived Endophytic Fungus Cladosporium cladosporioides
}

\author{
Fan-Zhong Zhang ${ }^{1,2,3}$, Xiao-Ming $\mathrm{Li}^{1,2}$, Xin Li ${ }^{1,2}$, Sui-Qun Yang ${ }^{1,2}$, Ling-Hong Meng ${ }^{1,2, *}$ and \\ Bin-Gui Wang 1,2,3,* \\ 1 Key Laboratory of Experimental Marine Biology, Center for Ocean Mega-Science, Institute of Oceanology, \\ Chinese Academy of Sciences, Nanhai Road 7, Qingdao 266071, China; fancyzfz@163.com (F.-Z.Z.); \\ lixmqdio@126.com (X.-M.L.); lixin871014@163.com (X.L.); suiqunyang@163.com (S.-Q.Y.) \\ 2 Laboratory of Marine Biology and Biotechnology, Qingdao National Laboratory for Marine Science and \\ Technology, Wenhai Road 1, Qingdao 266237, China \\ 3 University of Chinese Academy of Sciences, Yuquan Road 19A, Beijing 100049, China \\ * Correspondence: m8545303@163.com (L.-H.M.); wangbg@ms.qdio.ac.cn (B.-G.W.); \\ Tel: +86-532-8289-8553 (B.-G.W.)
}

Received: 8 April 2019; Accepted: 14 May 2019; Published: 17 May 2019

\begin{abstract}
Five new polyketides, namely, 5R-hydroxyrecifeiolide (1), 5S-hydroxyrecifeiolide (2), ent-cladospolide F (3), cladospolide G (4), and cladospolide H (5), along with two known compounds (6 and 7), were isolated from the endophytic fungal strain Cladosporium cladosporioides MA-299 that was obtained from the leaves of the mangrove plant Bruguiera gymnorrhiza. The structures of these compounds were established by extensive analysis of 1D/2D NMR data, mass spectrometric data, ECDs and optical rotations, and modified Mosher's method. The structures of 3 and $\mathbf{6}$ were confirmed by single-crystal X-ray diffraction analysis and this is the first time for reporting the crystal structures of these two compounds. All of the isolated compounds were examined for antimicrobial activities against human and aquatic bacteria and plant pathogenic fungi as well as enzymatic inhibitory activities against acetylcholinesterase. Compounds 1-4, 6, and $\mathbf{7}$ exhibited antimicrobial activity against some of the tested strains with MIC values ranging from 1.0 to $64 \mu \mathrm{g} / \mathrm{mL}$, while 3 exhibited enzymatic inhibitory activity against acetylcholinesterase with the $\mathrm{IC}_{50}$ value of $40.26 \mu \mathrm{M}$.
\end{abstract}

Keywords: mangrove plant; endophytic fungus; Cladosporium cladosporioides; polyketides; antimicrobial activity; acetylcholinesterase; enzymatic inhibitory activity

\section{Introduction}

The Cladosporium fungi, one of the largest genera of dematiaceous hyphomycetes, have attracted considerable attention of natural products researchers in recent years [1,2]. Versatile bioactive metabolites, such as cladosporin [3], macrolide [4], sulfur-containing diketopiperazines [5], indole alkaloids [6], hybrid polyketides [7], and diterpenes with 5-8-5 ring system [8], have been isolated from the Cladosporium strains. As part of our research on discovering structurally novel and biologically active natural products, a series of interesting metabolites have been obtained from marine-derived fungal strains [9,10], including those from Cladosporium species [11]. Our current chemical investigation on C. cladosporioides MA-299, an endophytic fungus obtained from the fresh inner leaves of the marine mangrove plant Bruguiera gymnorrhiza, led to the discovery of five new polyketides, namely, $5 R$-hydroxyrecifeiolide (1), 5S-hydroxyrecifeiolide (2), ent-cladospolide F (3) [12], cladospolide G (4), and cladospolide H (5) (Figure 1), as well as two known analogues, including iso-cladospolide B (6) $[13,14]$, and pandangolide 1 (7) [13,15] (Figure 1). Herein, we report the isolation, structure assignment, and biological evaluation of the isolated compounds. 


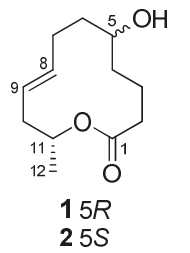<smiles>[R]C([R])CCCCCC[C@H]1OC(=O)CC1O</smiles><smiles>C[C@H](O)CCCCC/C=C1/C=CC(=O)O1</smiles>

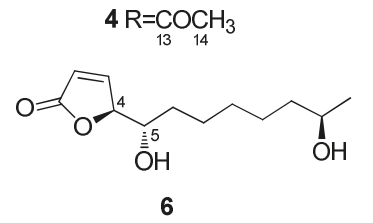<smiles>CC(C)CCCCC[C@@H](O)C(=O)[C@H](O)CC(=O)O</smiles>

Figure 1. Structures of the isolated compounds 1-7.

\section{Results and Discussion}

\subsection{Structure Elucidation of the New Compounds}

$5 R$-Hydroxyrecifeiolide (1) was isolated as a colorless oil and the molecular formula $\mathrm{C}_{12} \mathrm{H}_{20} \mathrm{O}_{3}$ was deduced from the (+)-HRESIMS data, indicating three degrees of unsaturation. The ${ }^{1} \mathrm{H}$ and ${ }^{13} \mathrm{C}$ NMR spectra of 1 showed the signals for one ester/lactone carbonyl, two olefinic and two oxygenated $\mathrm{sp}^{3}$ methines, six $\mathrm{sp}^{3}$ methylenes, and one methyl group (Table 1 ). In addition, the ${ }^{1} \mathrm{H}$ NMR data of 1 were quite similar to those of recifeiolide (11-hydroxy-trans-8-dodecenoic acid lactone) [16,17], except that one methylene $\left(\delta_{\mathrm{H}} 1.5-2.3 \mathrm{ppm}\right)$ in recifeiolide was replaced by an oxygenated methine $\left(\delta_{\mathrm{H}} 3.51 \mathrm{ppm}\right)$ in 1 . The key COSY correlations elucidated the connectivity from $\mathrm{H}-2$ through $\mathrm{H}-12$ (Figure 2). Key HMBC correlations from H-2 to C-1 and C-4, from H-3 to C-1 and C-5, and from H-11 to $\mathrm{C}-1$, connected $\mathrm{C}-1$ and $\mathrm{C}-2$ and determined the 12-membered macrolide skeleton of 1 (Figure 2). The relative configuration at C-5 and C-11 for 1 was established by the NOESY experiment (Figure S8). The NOESY correlations (Figure 3 ) from $\mathrm{H}-2 \beta$ to $\mathrm{H}-5$ and $\mathrm{H}-11$ revealed a $\beta$ orientation of these protons [18]. The coupling constants between $\mathrm{H}-8$ and $\mathrm{H}-9\left(\mathrm{~J}_{\mathrm{H}-8 / \mathrm{H}-9}=15.3 \mathrm{~Hz}\right)$ suggested the E-configuration of the C-8/C-9 double bond. The absolute configuration of C-5 of $\mathbf{1}$ was assigned by application of the modified Mosher's method [19]. The $\Delta \delta$ values obtained for the (S)- and (R)-MTPA esters (1a and $\mathbf{1 b}$, respectively) of $\mathbf{1}$ (Figure 4) suggested that the absolute configuration of C-5 is $R$. Furthermore, the electronic circular dichroism (ECD) spectrum of $\mathbf{1}$ was recorded and then computed with the time-dependent density function theory (TD-DFT) method at the gas-phase B3LYP/6-31G (d) level $[20,21]$. The calculated ECD spectra were produced by SpecDis software [22]. The experimental ECD spectrum for 1 matched well with the calculated spectrum for $11 R$ (Figure 5). Therefore, the $5 R$, $11 R$ configuration of 1 was established, and the trivial name $5 R$-hydroxyrecifeiolide was assigned. 


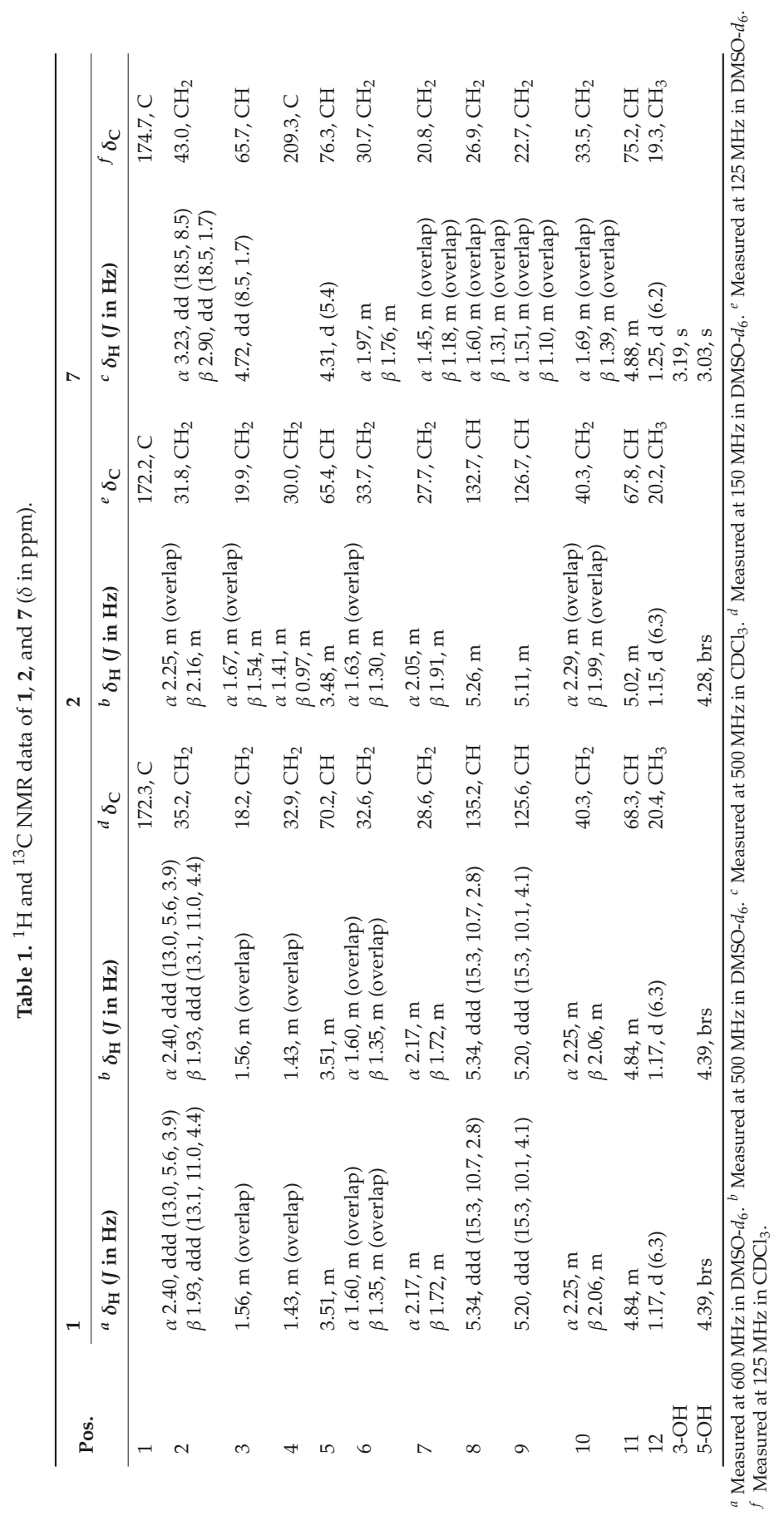




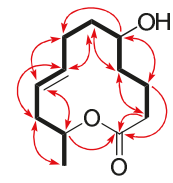

1

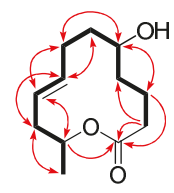

2

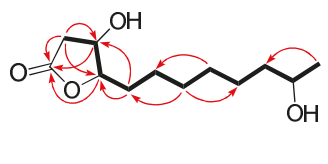

3

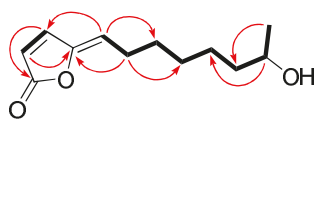

5

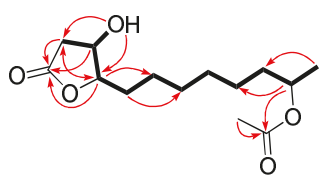

4

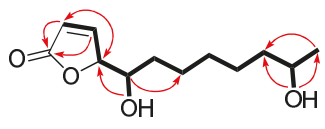

6

Figure 2. Key COSY (bold lines) and HMBC (red arrows) correlations for 1-6.

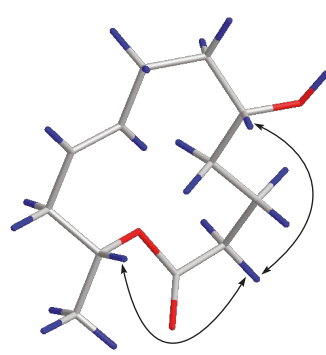

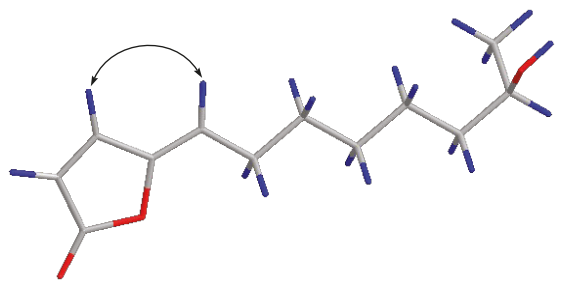

Figure 3. Key NOESY correlations for $\mathbf{1}$ and $\mathbf{5}$.

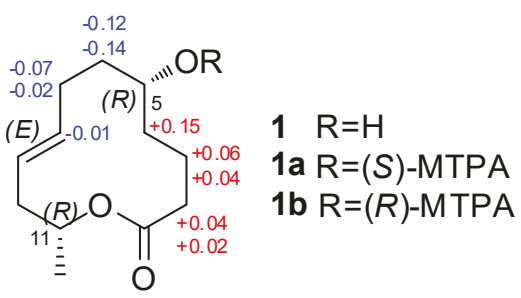

Figure 4. $\Delta \delta$ values $\left(\Delta \delta(\right.$ in ppm $\left.)=\delta_{S}-\delta_{R}\right)$ obtained for the $(S)$-and $(R)$-MTPA esters $(\mathbf{1} \mathbf{a}$ and $\mathbf{1 b}$, respectively) of $\mathbf{1}$.
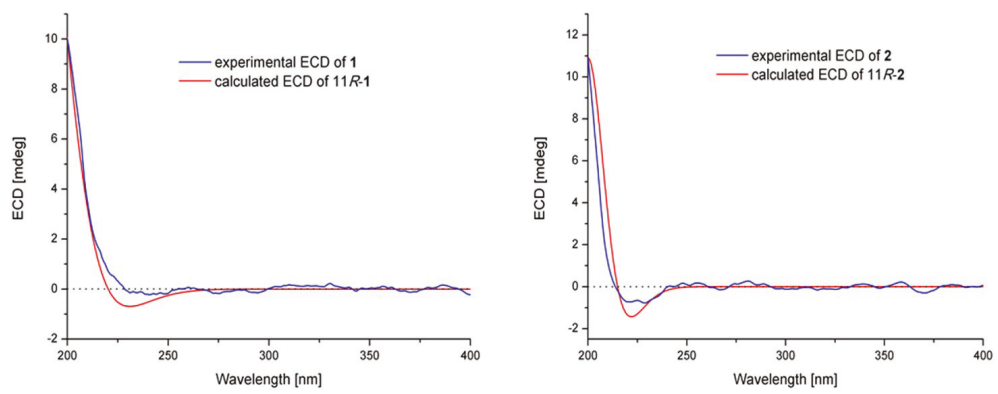

Figure 5. Comparison of experimental and calculated ECD spectra of $\mathbf{1}$ and $\mathbf{2}$. 
The molecular formula of 2 was determined as $\mathrm{C}_{12} \mathrm{H}_{20} \mathrm{O}_{3}$, which was the same as that of $\mathbf{1}$, according to its (+)-HRESIMS data. The ${ }^{1} \mathrm{H}$ and ${ }^{13} \mathrm{C}$ NMR spectra (Table 1 ) of 2 were similar to those of 1, except for the different ${ }^{13} \mathrm{C}$ chemical shifts at $C-5\left(\delta_{C} 70.2\right.$ in 1 , and $\delta_{C} 65.4$ in 2$)$ and its adjacent positions (C-2-C-4 and C-6-C-8), which indicated that compound 2 was the 5-epimer of $\mathbf{1}$. The chemical shifts at C-2 and C-8 ( $\gamma$-position of C-5) exhibited obvious difference in $\mathbf{2}$ and $\mathbf{1}$ probably due to the space effect. As expected, the experimental ECD spectrum of 2 matched well with the calculated spectrum of $11 R$ (Figure 5). The trivial name 5S-hydroxyrecifeiolide was assigned to 2.

Compound 3 was initially obtained as pale yellow powder and possessed a molecular formula $\mathrm{C}_{12} \mathrm{H}_{22} \mathrm{O}_{4}$ by (+)-HRESIMS, implying two degrees of unsaturation. The ${ }^{1} \mathrm{H}$ and ${ }^{13} \mathrm{C}$ NMR data (Table 2) exhibited signals attributed to one ester carbonyl, three oxygenated $\mathrm{sp}^{3}$ methines, seven $\mathrm{sp}^{3}$ methylenes, and one methyl group. These data were very similar to those of cladospolide F [12], suggesting that they had the same planar structure, which was also confirmed by the COSY and HMBC correlations (Figure 2). However, the signs of the optical rotations of $3(-29.41, \mathrm{MeOH})$ and cladospolide $\mathrm{F}$ $(+15.7, \mathrm{MeOH})$ were opposite, indicating that the absolute configurations of their stereogenic carbons were different. The relative configuration at C-3, C-4, and C-11 could not be concluded by NOESY experiment. Nevertheless, suitable crystals were obtained for X-ray diffraction analysis using $\mathrm{Cu} \mathrm{K} \alpha$ radiation which confirmed the absolute configuration of C-3, C-4 and C-11 as $3 R, 4 S$, and $11 R$ (Figure 6). The ent-cladospolide F was therefore assigned as a trivial name for 3.

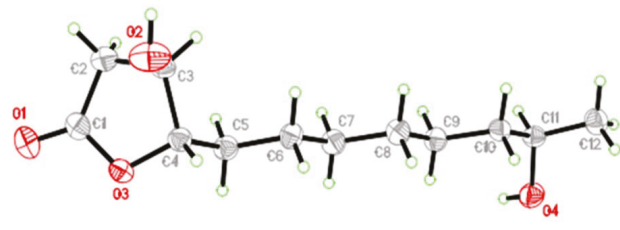

3

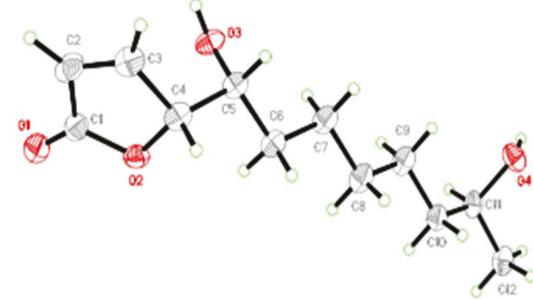

6

Figure 6. Ortep diagrams of ent-cladospolide F (3) and iso-cladospolide B (6).

Compound 4 was obtained as a pale yellow oil and its molecular formula was determined as $\mathrm{C}_{14} \mathrm{H}_{24} \mathrm{O}_{5}$ on the basis of (+)-HRESIMS, requiring three degrees of unsaturation. The ${ }^{1} \mathrm{H}$ and ${ }^{13} \mathrm{C}$ NMR data for 4 (Table 2) were quite similar to those of 3, except for the presence of additional ester carbonyl (C-13) and methyl (C-14) groups, which indicated the replacement of 11-OH group in 3 by an OAc group in 4, and thus caused the down-field shift of 11- $\mathrm{H}$ from $\delta_{\mathrm{H}} 3.55$ in 3 to $\delta_{\mathrm{H}} 4.78$ in 4 . Detailed interpretation of the COSY and HMBC spectra revealed that 4 was an analogue of 3 , with the hydroxyl group at C-11 in 3 being replaced by an acetoxyl group in 4 . The HMBC correlation from $\mathrm{H}-11$ to $\mathrm{C}-13$ established the presence of an acetoxyl group at C-11, and the planar structure of 4 was hence confirmed as shown (Figure 2). In a biogenetic perspective, it was tentatively assigned the same relative configuration as that of 3 . The similar optical rotations of $4(-24.56, \mathrm{MeOH})$ and 3 $(-29.41, \mathrm{MeOH})$ also supported that the absolute configurations of the stereogenic carbons in 4 were the same as those in 3 . Therefore, the absolute configurations of the stereogenic carbons in 4 were tentatively assigned as $3 R, 4 S$, and $11 R$, and the trivial name cladospolide $G$ was assigned. Acetylation of compounds 3 and 4 using acetyl chloride yielded the same diacetylated derivative, which further correlated the structure relationship of compounds 3 and 4. 


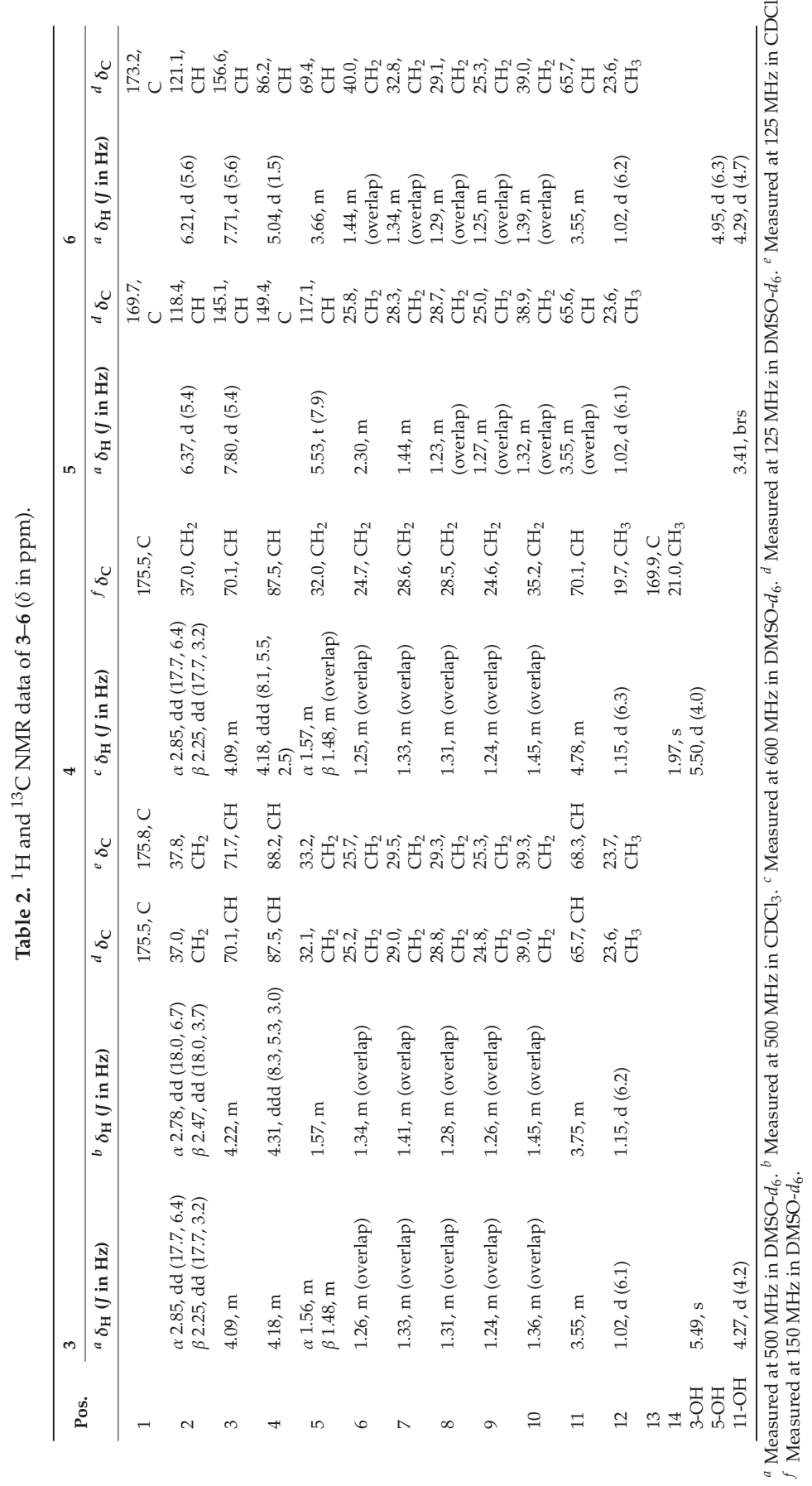


Compound 6 was isolated as colorless crystals and gave ion peaks at $\mathrm{m} / \mathrm{z} 229.1432[\mathrm{M}+\mathrm{H}]^{+}$ and $246.1699\left[\mathrm{M}+\mathrm{NH}_{4}\right]^{+}$in the (+)-HRESIMS, corresponding to a molecular formula $\mathrm{C}_{12} \mathrm{H}_{20} \mathrm{O}_{4}$, indicating three degrees of unsaturation. All the ${ }^{1} \mathrm{H}$ and ${ }^{13} \mathrm{C}$ NMR data of 6 were quite similar to those of the previously reported polyketide metabolite iso-cladospolide B [13]. The COSY and HMBC correlations (Figure 2) confirmed that the planar structure of $\mathbf{6}$ was the same as that of iso-cladospolide B. The high similarity of specific rotations of $6\left([\alpha]_{\mathrm{D}}^{25}=-90.91(\right.$ c $\left.0.11, \mathrm{MeOH})\right)$ and iso-cladospolide $\mathrm{B}\left([\alpha]_{\mathrm{D}}^{25}=-90(c 0.23, \mathrm{MeOH})\right)[13]$ suggested that they may have the same relative and absolute stereochemistry. However, neither the relative nor the absolute configuration was determined [13]. In 2001, Franck et al. carried out the first synthesis of iso-cladospolide B and proposed that it has the $4 S, 5 S$, and $11 R$ configuration [14]. Later, in 2005, the absolute configuration of iso-cladospolide B, isolated from Cladosporium sp. isolated from the Red Sea sponge Niphates rowi, was assigned to be $4 S$, $5 S$, and $11 S\left([\alpha]_{\mathrm{D}}^{28}=-61(c 16.6, \mathrm{MeOH})\right)[15]$. It was later stated that both diastereomers appear to be natural products and $(4 S, 5 S, 11 S)$-isomer referred to as 11-epi-iso-cladospolide B [23,24]. The relative configuration of 6 could not be assigned by NOESY experiments but the coupling constant for C-4 $(J=1.5 \mathrm{~Hz})$ confirmed the threo relative configuration [14]. Upon slow evaporation of the solvent $\left(\mathrm{MeOH}-\mathrm{H}_{2} \mathrm{O}\right)$, compound 6 was crystallized and the X-ray analysis was carried out, which was first reported for iso-cladospolide B (Figure 4). The $\mathrm{Cu} \mathrm{K} \alpha$ Flack parameter 0.5 (7) allowed preliminary confirmation of the relative configurations of 6 as $4 S^{*}, 5 S^{*}, 11 R^{*}$.

Compound 5 was obtained as a pale yellow oil and possessed a molecular formula of $\mathrm{C}_{12} \mathrm{H}_{18} \mathrm{O}_{3}$ by (+)-HRESIMS, implying four degrees of unsaturation. The 1D NMR data (Table 2) and HSQC spectrum (Figure S38) suggested signals attributed to one ester and one olefinic quaternary carbons, one oxygenated and three olefinic methines, five $\mathrm{sp}^{3}$ methylenes, and one methyl group. These NMR data were similar to those of iso-cladospolide B (6) [13]. However, resonances for two oxygenated methines (C-4 and C-5) in 6 were not detected in the NMR spectra of 5. Instead, two additional olefinic signals including one quaternary $\mathrm{sp}^{2}\left(\mathrm{C}-4, \delta_{\mathrm{C}} 149.4\right)$ and one methine $\mathrm{sp}^{2}\left(\mathrm{C}-5, \delta_{\mathrm{C}} 117.1 / \delta_{\mathrm{H}} 5.53\right)$ carbons were observed in the NMR spectra of 5 (Table 2). These data indicated that 5 was a reduced analogue of 6 , and this deduction was supported by the molecular formula. The COSY and HMBC spectra established the structure of $\mathbf{5}$ as shown in Figure 1. In the NOESY experiment, the correlation between $\mathrm{H}-3$ and $\mathrm{H}-5$ indicated the Z-conformation of the double bond between C-4 and C-5 (Figure 3). The absolute stereochemistry of 5 could not be determined by Mosher's method because of the limited amount of material available. From a biogenetic point of view, $\mathbf{5}$ was putatively produced by reduction of 6 . Therefore, it was tentatively assigned the absolute configuration of C-11 of 5 as $11 R$. From these data, the name cladospolide $\mathrm{H}$ was assigned for $\mathbf{5}$.

Compound 7 was acquired as white powder and showed ion peaks at $m / z 267.1197[\mathrm{M}+\mathrm{Na}]^{+}$ in the positive HRESIMS, corresponding to a molecular formula of $\mathrm{C}_{12} \mathrm{H}_{20} \mathrm{O}_{5}$. A literature search indicated that all the ${ }^{1} \mathrm{H}$ and ${ }^{13} \mathrm{C}$ NMR data of 7 were almost the same as those of previously reported compound pandangolide $1[13,15]$. The almost exactly the same specific rotations of $7\left([\alpha]_{\mathrm{D}}^{25}=-30.16\right.$ $(\mathrm{c} 1.22, \mathrm{MeOH}))$ and pandangolide $1\left([\alpha]_{\mathrm{D}}^{25}=-30(\mathrm{c} 2.3, \mathrm{MeOH})\right)[15]$ revealed that they may have the same relative and absolute configurations.

\subsection{Biological Activities of the Isolated Compounds}

Compounds 1-7 were tested for antimicrobial activities against two human pathogens (Escherichia coli, Staphylococcus aureus), ten aquatic bacteria (Aeromonas hydrophilia, Edwardsiella ictarda, E. tarda, Micrococcus luteus, Pseudomonas aeruginosa, Vibrio alginolyticus, V. anguillarum, V. harveyi, V. parahaemolyticus, and V. vulnificus), and 15 plant pathogenic fungi (Alternaria solani, Bipolaris sorokiniana, Ceratobasidium cornigerum, Colletotrichum glecosporioides, Coniothyrium diplodiella, Fusarium graminearum, F. oxysporum f. sp. cucumerinum, F. oxysporum f. sp. momodicae, F. oxysporum f. sp. radicis lycopersici, F. solani, Glomerella cingulate, Helminthosporium maydis, Penicillium digitatum, Physalospora piricola Nose, and Valsa mali). As shown in Table 3, 3 exhibited moderate inhibitory activities against human pathogenic bacteria S. aureus with MIC value of $8.0 \mu \mathrm{g} / \mathrm{mL}$. Compound 4 showed potent inhibitory activities 
against plant-pathogenic fungi (G. cingulate and F. oxysporum f. sp. cucumerinum), each with an MIC value of $1.0 \mu \mathrm{g} / \mathrm{mL}$, while 7 showed activity against aquatic bacterium (E. ictarda) and plant-pathogenic fungus (G. cingulate), with MIC values of 4.0 and $1.0 \mu \mathrm{g} / \mathrm{mL}$, respectively.

Table 3. Antimicrobial Activities of 1-7 (MIC, $\mu \mathrm{g} / \mathrm{mL})^{\mathrm{a}}$.

\begin{tabular}{|c|c|c|c|c|c|c|c|}
\hline \multirow{2}{*}{ Strains } & \multicolumn{7}{|c|}{ Compounds } \\
\hline & 1 & 2 & 3 & 4 & 6 & 7 & $\begin{array}{c}\text { Positive } \\
\text { control }\end{array}$ \\
\hline E. coli $^{\mathrm{b}}$ & - & - & - & 32 & 32 & - & 2.0 \\
\hline S. aureus ${ }^{b}$ & - & - & 8.0 & - & - & 32 & 1.0 \\
\hline E. tarda $^{\mathrm{b}}$ & - & - & - & - & 32 & - & 0.5 \\
\hline E. ictarda ${ }^{\mathrm{b}}$ & 32 & - & 16 & - & 16 & 4.0 & 0.5 \\
\hline G. cingulate ${ }^{\mathrm{c}}$ & - & 16 & - & 1.0 & 64 & 1.0 & 0.5 \\
\hline B. sorokiniana ${ }^{\mathrm{c}}$ & - & - & - & 32 & - & - & 0.5 \\
\hline P. aeruginosa $a^{\mathrm{c}}$ & 32 & - & 64 & - & - & 32 & 2.0 \\
\hline F.oxysporum f. sp. Cucumerinum ${ }^{\mathrm{c}}$ & - & - & - & 1.0 & - & - & 0.5 \\
\hline
\end{tabular}

${ }^{a}(-)=\mathrm{MIC}>64 \mu \mathrm{g} / \mathrm{mL},{ }^{b}$ Chloramphenicol as positive control, ${ }^{c}$ Amphotericin B as positive control.

Compounds 1-7 were also evaluated for acetylcholinesterase inhibitory activity. Compound 3 exhibited potent activity against acetylcholinesterase with the $\mathrm{IC}_{50}$ value of $40.26 \mu \mathrm{M}$. The other compounds have a weak activity $\left(\mathrm{IC}_{50}>50 \mu \mathrm{M}\right)$.

\section{Experimental Section}

\subsection{General Experimental Procedures}

Melting points were determined by an SGW X-4 micro-melting-point apparatus (Shanghai Shenguang Instrument Co. Ltd, Shanghai, China). Optical rotations were measured on an Optical Activity AA-55 polarimeter (Optical Activity Ltd., Cambridgeshire, UK). UV spectra were measured on a PuXi TU-1810 UV-visible spectrophotometer (Shanghai Lengguang Technology Co. Ltd., Shanghai, China). ECD spectra were acquired on a Chirascan spectropolarimeter (Applied Photophysics Ltd., Leatherhead, UK). The ${ }^{1} \mathrm{H},{ }^{13} \mathrm{C}$, and 2D NMR spectra were acquired using a Bruker Avance 500 or $600 \mathrm{M}$ spectrometer (Bruker Biospin Group, Karlsruhe, Germany). Chemical shifts $(\delta)$ were expressed in ppm with reference to the solvent peaks $\left({ }^{13} \mathrm{C}, \mathrm{CDCl}_{3}: 77.16 \mathrm{ppm}, \mathrm{DMSO}-d_{6}: 39.52 \mathrm{ppm} ;{ }^{1} \mathrm{H}, \mathrm{CDCl}_{3}: 7.26 \mathrm{ppm}\right.$, DMSO- $\left.d_{6}: 2.50 \mathrm{ppm}\right)$. Mass spectra were obtained from an API QSTAR Pulsar 1 mass spectrometer (Applied Biosystems, Foster, Waltham, MA, USA). Analytical HPLC analyses were performed using a Dionex HPLC system (Dionex, Sunnyvale, CA, USA) equipped with P680 pump, ASI-100 automated sample injector, and UVD340U multiple wavelength detector controlled by Chromeleon software (version 6.80). Column chromatography (CC) was performed with silica gel (200-300 mesh, Qingdao Haiyang Chemical Factory, Qingdao, China), Lobar LiChroprep RP-18 (40-60 $\mu \mathrm{m}$, Merck, Darmstadt, Germany), and Sephadex LH-20 (18-110 $\mu \mathrm{m}$, Merck).

\subsection{Fungal Material}

The fungal strain Cladosporium cladosporioides MA-299 was isolated from the leaves of the mangrove plant Bruguiera gymnorrhiza, collected in Hainan Island, China, in March 2015. The strain was identified as Cladosporium cladosporioides by analysis of its ITS region of the rDNA, which is the same (100\%) as that of C. cladosporioides DCF-1 (accession no. MG208055). The sequence data were deposited in GenBank with the accession number MH822624. The strain is preserved at Key Laboratory of Experimental Marine Biology, Institute of Oceanology of the Chinese Academy of Sciences (IOCAS). 


\subsection{Fermentation}

For chemical investigations, the strain of C. cladosporioides MA-299 was cultured on PDA (Potato Dextrose Agar) medium at $28^{\circ} \mathrm{C}$ for six days and then inoculated into $100 \times 1 \mathrm{~L}$ flasks, each containing $70 \mathrm{~g}$ of rice, $0.1 \mathrm{~g}$ corn syrup, $0.3 \mathrm{~g}$ peptone, $0.1 \mathrm{~g}$ methionine and $100 \mathrm{~mL}$ seawater that was obtained from the Huiquan Gulf of the Yellow Sea near the campus of IOCAS, statically cultured for 48 days at room temperature.

\subsection{Extraction and Isolation}

After 48 days, the fermented rice substrate was mechanically fragmented and then extracted three times with $300 \mathrm{~mL}$ EtOAc every flask. All of the EtOAc extracts were filtered and evaporated under reduced pressure to yield a crude extract $(52.3 \mathrm{~g})$.

The crude extract was subjected to a silica gel vacuum liquid chromatography (VLC), eluting with different solvents of increasing polarity from petroleum ether (PE) to MeOH to yield ten fractions (Frs. 1-10) based on TLC and HPLC analysis. Fr. 5 (2.1 g) was further purified by reversed-phase column chromatography (CC) over Lobar LiChroprep RP-18 with a $\mathrm{MeOH}-\mathrm{H}_{2} \mathrm{O}$ gradient (from 10: 90 to 100 : 0) to afford four subfractions (Frs. 5.1-5.4). Fr. 5.2 was further purified by CC on Sephadex LH-20 $(\mathrm{MeOH})$ and then by preparative TLC (plate: $20 \times 20 \mathrm{~cm}$, developing solvents: $\mathrm{CH}_{2} \mathrm{Cl}_{2} / \mathrm{MeOH}, 30: 1$ ) to obtain 5 (2.6 mg). Fr. 5.3 was subjected to $\mathrm{CC}$ on silica gel eluted with $\mathrm{CH}_{2} \mathrm{Cl}_{2}-\mathrm{MeOH}(100: 1$ to $5: 1)$ to obtain 1 (4.1 mg) and 2 (3.0 mg). Fr. 6 (1.7 g) was further fractionated by CC over Lobar LiChroprep RP-18 with a $\mathrm{MeOH} / \mathrm{H}_{2} \mathrm{O}$ gradient (from 10:90 to 100:0) to yield six subfractions (Frs. 6.1-6.6). Fr. 6.1 $(112.4 \mathrm{mg}$ ) was further purified by prep. TLC (plate: $20 \times 20 \mathrm{~cm}$, developing solvents: petroleum ether/acetone, 2:1) and then on Sephadex LH-20 (MeOH) to obtain 7 (3.2 mg). Fr. 6.5 was subjected to $\mathrm{CC}$ on silica gel eluted with $\mathrm{CH}_{2} \mathrm{Cl}_{2}-\mathrm{MeOH}$ (150:1 to 70:1) to obtain 4 (5.7 mg). Further purification of Fr. 7 (3.6 g) by CC over Lobar LiChroprep RP-18 with a $\mathrm{MeOH} / \mathrm{H}_{2} \mathrm{O}$ gradient (from 10:90 to 100:0) yielded seven subfractions (Frs. 7.1-7.7). Fr. 7.1 (736.2 mg) was purified by CC on silica gel eluting with a petroleum ether-acetone gradient (from 10:1 to 2:1), and further fractionated by Sephadex LH-20 $(\mathrm{MeOH})$ to afford $3(91.6 \mathrm{mg})$. Fr. $7.2(960.7 \mathrm{mg})$ was further separated by CC on silica gel eluting with a petroleum ether-acetone gradient (from 10:1 to 1:1) purification, to afford 6 (23.4 mg).

5R-Hydroxyrecifeiolide (1): Colourless oil; $[\alpha]_{\mathrm{D}}^{25}+33.33$ (c 0.09, MeOH); UV (MeOH) $\lambda_{\max }(\log \varepsilon) 205$ (3.06), 220 (3.01); ECD (7.55 mM, MeOH) $\lambda_{\max }(\Delta \varepsilon) 233(-0.01) \mathrm{nm} ;{ }^{1} \mathrm{H}$ and ${ }^{13} \mathrm{C}$ NMR data, see Table 1; ESIMS $m / z 235\left[\mathrm{M}+\mathrm{Na}^{+} ;(+)\right.$-HRESIMS at $m / z 235.1298[\mathrm{M}+\mathrm{Na}]^{+}\left(\right.$calcd for $\mathrm{C}_{12} \mathrm{H}_{20} \mathrm{O}_{3} \mathrm{Na}, 235.1305$ ).

5S-hydroxyrecifeiolide (2): Colourless oil; $[\alpha]_{\mathrm{D}}^{25}+23.07$ (c 0.13, MeOH); UV (MeOH) $\lambda_{\max }(\log \varepsilon) 205$ (3.01), 220 (3.06); ECD (8.49 mM, MeOH) $\lambda_{\max }(\Delta \varepsilon) 230(-0.03) \mathrm{nm} ;{ }^{1} \mathrm{H}$ and ${ }^{13} \mathrm{C}$ NMR data, see Table 1; ESIMS $m / z 235\left[\mathrm{M}+\mathrm{Na}^{+} ;(+)\right.$-HRESIMS at $m / z 235.1299[\mathrm{M}+\mathrm{Na}]^{+}$(calcd for $\mathrm{C}_{12} \mathrm{H}_{20} \mathrm{O}_{3} \mathrm{Na}, 235.1305$ ).

ent-Cladospolide F (3): Colorless crystal (MeOH); mp 59-62 ${ }^{\circ} \mathrm{C} ;[\alpha]_{\mathrm{D}}^{25}-29.41$ (c 0.17, MeOH); UV $(\mathrm{MeOH}) \lambda_{\max }(\log \varepsilon) 206$ (3.42); ECD (7.82 mM, MeOH) $\lambda_{\max }(\Delta \varepsilon) 210(+0.28) \mathrm{nm}, 267(+0.03) \mathrm{nm} ;{ }^{1} \mathrm{H}$ and ${ }^{13} \mathrm{C}$ NMR data, see Table 2; ESIMS $m / z 231[\mathrm{M}+\mathrm{H}]^{+}, m / z 253[\mathrm{M}+\mathrm{Na}]^{+} ;(+)-\mathrm{HRESIMS}$ at $m / z$ $231.1589[\mathrm{M}+\mathrm{H}]^{+}$(calcd for $\mathrm{C}_{12} \mathrm{H}_{23} \mathrm{O}_{4}, m / z 231.1591$ ), at $m / z 253.1407[\mathrm{M}+\mathrm{Na}]^{+}$(calcd for $\mathrm{C}_{12} \mathrm{H}_{22} \mathrm{O}_{4} \mathrm{Na}$, $m / z 253.1410)$.

Cladospolide G (4): Yellow oil; $[\alpha]_{\mathrm{D}}^{25}-24.56$ (c 0.57, MeOH); UV (MeOH) $\lambda_{\max }(\log \varepsilon) 206(3.49), 220$ (3.27), 275 (2.62); ECD (4.04 mM, MeOH) $\lambda_{\max }(\Delta \varepsilon) 207(+0.80) \mathrm{nm}, 323(-0.10) \mathrm{nm} ;{ }^{1} \mathrm{H}$ and ${ }^{13} \mathrm{C}$ NMR data, see Table 2; ESIMS $m / z 273[\mathrm{M}+\mathrm{H}]^{+}, m / z 295[\mathrm{M}+\mathrm{Na}]^{+} ;(+)$-HRESIMS at $m / z 273.1700[\mathrm{M}+\mathrm{H}]^{+}$ (calcd for $\mathrm{C}_{14} \mathrm{H}_{25} \mathrm{O}_{5}, m / z 273.1697$ ), at $m / z 290.1970\left[\mathrm{M}+\mathrm{NH}_{4}\right]^{+}$(calcd for $\mathrm{C}_{14} \mathrm{H}_{28} \mathrm{O}_{5} \mathrm{~N}, m / z 290.1962$ ), at $m / z 295.1515[\mathrm{M}+\mathrm{Na}]^{+}$(calcd for $\mathrm{C}_{14} \mathrm{H}_{24} \mathrm{O}_{5} \mathrm{Na}, m / z 295.1516$ ).

Cladospolide $\mathrm{H}$ (5): pale yellow oil; ${ }^{1} \mathrm{H}$ and ${ }^{13} \mathrm{C}$ NMR data, see Table 2; ESIMS m/z 233 [M + Na] ${ }^{+}$; (+)-HRESIMS at $m / z 233.1151[\mathrm{M}+\mathrm{Na}]^{+}$(calcd for $\mathrm{C}_{12} \mathrm{H}_{18} \mathrm{O}_{3} \mathrm{Na}, \mathrm{m} / z$ 233.1148). (The optical rotation and ECD of 5 could not be detected due to the limited quantity). 
Iso-cladospolide B (6): colorless crystal (MeOH); mp 105-112 ${ }^{\circ} \mathrm{C} ;[\alpha]_{\mathrm{D}}^{25}-90.91$ (c 0.11, MeOH); UV $(\mathrm{MeOH}) \lambda_{\max }(\log \varepsilon) ; \mathrm{ECD}(9.21 \mathrm{mM}, \mathrm{MeOH}) \lambda_{\max }(\Delta \varepsilon) 213(-5.69) \mathrm{nm} ;{ }^{1} \mathrm{H}$ and ${ }^{13} \mathrm{C}$ NMR data, see Table 2; (+)-HRESIMS at $m / z 229.1432[\mathrm{M}+\mathrm{H}]^{+}$(calcd for $\left.\mathrm{C}_{12} \mathrm{H}_{21} \mathrm{O}_{4}, 229.1434\right)$, at $\mathrm{m} / \mathrm{z} 246.1699[\mathrm{M}+$ $\left.\mathrm{NH}_{4}\right]^{+}$(calcd for $\mathrm{C}_{12} \mathrm{H}_{24} \mathrm{O}_{4} \mathrm{~N}, 246.1700$ ).

\subsection{X-Ray Crystallographic Analysis of Compounds $\mathbf{3}$ and $\mathbf{6}$}

All crystallographic data were collected on an Agilent Xcalibur Eos Gemini CCD plate diffractometer, using graphite monochromatized $\mathrm{Cu} / \mathrm{K} \alpha$ radiation $(\lambda=1.54178 \AA$ ) [25]. The data were corrected for absorption by using the program SADABS [26]. The structures were solved by direct methods with the SHELXTL software package [27]. All nonhydrogen atoms were refined anisotropically. The $\mathrm{H}$ atoms were located by geometrical calculations, and their positions and thermal parameters were fixed during the structure refinement. The structure was refined by full-matrix least-squares techniques [28].

Crystal data for compound 3: $\mathrm{C}_{12} \mathrm{H}_{22} \mathrm{O}_{4}$, F.W. $=230.30$, Orthorhombic space group P2(1)2(1)2(1), unit cell dimensions $a=5.4655(4) \AA, b=5.5812(6) \AA, c=41.275(3) \AA, V=1259.06(19) \AA^{3}, \alpha=\beta=\gamma=90^{\circ}$, $Z=4, d_{\text {calcd }}=1.215 \mathrm{mg} / \mathrm{m}^{3}$, crystal dimensions $0.40 \times 0.28 \times 0.10 \mathrm{~mm}^{3}, \mu=0.734 \mathrm{~mm}^{-1}, F(000)=504$. The 2385 measurements yielded 1827 independent reflections after equivalent data were averaged, and Lorentz and polarization corrections were applied. The final refinement gave $R_{1}=0.0487$ and $\mathrm{w} R_{2}=0.0970(I>2 \sigma(I))$. The Flack parameter was $0.0(5)$ in the final refinement for all 1827 reflections with 147 Friedel pairs.

Crystal data for compound 6: $\mathrm{C}_{12} \mathrm{H}_{20} \mathrm{O}_{4}, \mathrm{~F} . \mathrm{W} .=228.13$, Orthorhombic space group P2(1)2(1)2(1), unit cell dimensions $a=5.5217(5) \AA, b=7.6778(7) \AA, c=28.947(2) \AA, V=1227.17(19) \AA^{3}, \alpha=\beta=\gamma=90^{\circ}$, $Z=6, d_{\text {calcd }}=1.236 \mathrm{mg} / \mathrm{m}^{3}$, crystal dimensions $0.35 \times 0.24 \times 0.16 \mathrm{~mm}^{3}, \mu=0.752 \mathrm{~mm}^{-1}, F(000)=496$. The 5282 measurements yielded 2081 independent reflections after equivalent data were averaged, and Lorentz and polarization corrections were applied. The final refinement gave $R_{1}=0.0727$ and $\mathrm{w} R_{2}=0.1620(I>2 \sigma(I))$. The Flack parameter was $0.5(7)$ in the final refinement for all 2081 reflections with 150 Friedel pairs.

\subsection{Acetylation of Compounds $\mathbf{3}$ and $\mathbf{4}$}

To $5 \mu \mathrm{mol}$ samples of compound 3 or 4 in glass-stoppered flask were added $400 \mu \mathrm{L}$ dichloromethane, then excess amount of triethylamine was added. Drip $20 \mu \mathrm{mol}$ of acetylchloride slowly into the flask in ice bath and keeping the reaction for $12 \mathrm{~h}$. Then stop the reaction by adding $20 \mu \mathrm{L}$ of water into the flask. The progress of the reaction was monitored by TLC analysis. The resulting reaction mixture was extracted with dichloromethane $(2 \times 400 \mu \mathrm{L})$, dried with $\mathrm{Na}_{2} \mathrm{SO}_{4}$, and concentrated in vacuo to obtain the product.

\subsection{Antimicrobial Assay}

Antimicrobial evaluation against two human pathogens (Escherichia coli EMBLC-1, Staphylococcus aureus EMBLC-2) and ten aquatic pathogens (Aeromonas hydrophilia QDIO-1, Edwardsiella ictarda QDIO-9, E. tarda QDIO-2, Micrococcus luteus QDIO-3, Pseudomonas aeruginosa QDIO-4, Vibrio alginolyticus QDIO-5, V. anguillarum QDIO-6, V. harveyi QDIO-7, V. parahaemolyticus QDIO-8, and V. vulnificus QDIO-10), as well as 15 plant-pathogenic fungi (Alternaria solani QDAU-1, Bipolaris sorokiniana QDAU-5, Ceratobasidium cornigerum QDAU-6, Colletotrichum glecosporioides QDAU-2, Coniothyrium diplodiella QDAU-7, Fusarium graminearum QDAU-4, F. oxysporum $\mathrm{f}$. sp. cucumerinum QDAU-8, F. oxysporum $\mathrm{f}$. sp. momodicae QDAU-9, F. oxysporum f. sp. radicis lycopersici QDAU-10, F. solani QDAU-11, Glomerella cingulate QDAU-12, Helminthosporium maydis QDAU-15, Penicillium digitatum QDAU-14, Physalospora piricola Nose QDAU-15, and Valsa mali QDAU-16), was carried out by the 96-well microtiter plates assay [29]. The pathogens were obtained from the Institute of Oceanology, Chinese Academy of Sciences. Chloramphenicol and amphotericin were used as positive controls for bacteria and fungi, respectively. All of the tested compounds and controls were dissolved in DMSO. 


\subsection{Enzyme inhibitory Assay}

A modified Ellman's method [30] was used to evaluate AChE inhibitory activities of compounds 1-7 in 96-well microplates. Tacrine was used as the standard inhibitor, and control test was performed without the presence of AChE inhibitors. All the inhibitors, solubilized in $\mathrm{MeOH}$, were diluted stepwise from initial concentration of $32 \mu \mathrm{M}$. Every experiment was performed in triplicate. $5 \mu \mathrm{L}$ inhibitor was added to each well and dried, then $50 \mu \mathrm{L}$ phosphate buffer (PBS, $10 \times 0.01 \mathrm{M}$, pH 7.2-7.4) was dispensed followed by $10 \mu \mathrm{L}$ AChE (2 U/mL) and $20 \mu \mathrm{L} 5,5$-dithiobis 2-nitrobenzoic acid (DTNB, $5 \mathrm{mM}$ ). After $10 \mathrm{~min}$ culturing at $37^{\circ} \mathrm{C}, 20 \mu \mathrm{L}$ acetylthiocholine iodide (ATCh, $10 \mathrm{mM}$ ) was added and then OD was read at $405 \mathrm{~nm}$ over another period of 10 min culturing at $37{ }^{\circ} \mathrm{C}$. The enzymatic inhibitory activity was calculated according to the following equation: Inhibition $\%=\left(\left(C-C_{\text {backgroud }}\right)-\left(A-A_{\text {backgroud }}\right)\right) /\left(C-C_{\text {backgroud }}\right) \times 100 \%$, where $C$ is the OD value of the control and $\mathrm{A}$ is the $\mathrm{OD}$ value in the presence of the inhibitor. As for the background, ATCh was replaced by PBS in A and C and bovine albumin (BSA, 1mg/mL) took the place of AChE in C.

\section{Conclusions}

In summary, five new compounds (1-5) and two previously reported metabolites (6 and 7) were isolated from the mangrove-derived endophytic fungus C. cladosporioides MA-299. The structures of 3 and 6 were confirmed by single-crystal X-ray diffraction analysis and this is the first time for reporting the crystal structures of the two compounds. Compound 4 showed potent inhibitory activity against plant-pathogenic fungi (G. cingulate and F.oxysporum f. sp. cucumerinum), each with MIC value of $1.0 \mu \mathrm{g} / \mathrm{mL}$, while 7 showed potent inhibitory activity against aquatic bacterium (E. ictarda) and plant-pathogenic fungus (G. cingulate), with MIC values of 4.0 and $1.0 \mu \mathrm{g} / \mathrm{mL}$ respectively. Compound 3 exhibited moderate inhibitory activity against human pathogenic bacterium $S$. aureus with MIC value of $8.0 \mu \mathrm{g} / \mathrm{mL}$ and acetylcholinesterase inhibitory activity with $\mathrm{IC}_{50}$ value of $40.26 \mu \mathrm{M}$.

Supplementary Materials: The following are available online at http://www.mdpi.com/1660-3397/17/5/296/s1, 1D and 2D NMR spectra and ECDs of compounds 1-5 as well as crystal packing of compounds 3 and 6 .

Author Contributions: F.-Z.Z. performed the experiments for the isolation, structure elucidation, and antimicrobial evaluation; and prepared the manuscript; X.-M.L. performed the 1D and 2D NMR experiments; X.L. contributed to part of the structure determination; S.-Q.Y. contributed the optimization of fermentation; L.-H.M contributed to part of the structure determination and jointly supervised the research; B.-G.W. supervised the research work and revised the manuscript.

Funding: Financial support from the Natural Science Foundation of China (81673351 and 31600267) and from the Natural Science Foundation of Shandong Province, China (ZR2016BQ17), is gratefully acknowledged. Bin-Gui Wang acknowledges the support of Taishan Scholar project from Shandong province.

Conflicts of Interest: The authors declare no conflict of interest.

\section{References}

1. Bensch, K.; Groenewald, J.Z.; Braun, U.; Dijksterhuis, J.; de Jesus Yáñez-Morales, M.; Crous, P.W. Common but different: The expanding realm of Cladosporium. Stud. Mycol. 2015, 82, 23-74. [CrossRef]

2. Imhoff, J.F. Natural products from marine fungi-still an underrepresented resource. Mar. Drugs 2016, 14, 19. [CrossRef] [PubMed]

3. Jacyno, J.M.; Harwood, J.S.; Cutler, H.G.; Lee, M.K. Isocladosporin, a biologically active isomer of cladosporin from Cladosporium cladosporioides. J. Nat. Prod. 1993, 56, 1397-1401. [CrossRef]

4. Shigemori, H.; Kasai, Y.; Komatsu, K.; Tsuda, M.; Mikami, Y.; Kobayashi, J. Sporiolides A and B, new cytotoxic twelve-membered macrolides from a marine-derived fungus Cladosporium species. Mar. Drugs 2004, 2 , 164-169. [CrossRef]

5. Gu, B.B.; Zhang, Y.Y.; Ding, L.J.; He, S.; Wu, B.; Dong, J.D.; Zhu, P.; Chen, J.J.; Zhang, J.R.; Yan, X.J. Preparative separation of sulfur-containing diketopiperazines from marine fungus Cladosporium sp. using high-speed counter-current chromatography in stepwise elution mode. Mar. Drugs 2015, 13, 354-365. [CrossRef] [PubMed] 
6. Peng, J.X.; Lin, T.; Wang, W.; Xin, Z.H.; Zhu, T.J.; Gu, Q.Q.; Li, D.H. Antiviral alkaloids produced by the mangrove-derived fungus Cladosporium sp. PJX-41. J. Nat. Prod. 2013, 76, 1133-1140. [CrossRef]

7. Wu, G.W.; Sun, X.H.; Yu, G.H.; Wang, W.; Zhu, T.J.; Gu, Q.Q.; Li, D.H. Cladosins A-E, hybrid polyketides from a deep-sea-derived fungus, Cladosporium sphaerospermum. J. Nat. Prod. 2014, 77, 270-275. [CrossRef]

8. Sassa, T.; Ooi, T.; Nukina, M.; Ikeda, M.; Kato, N. Structural confirmation of cotylenin A, a novel fusicoccane-diterpene glycoside with potent plant growth-regulating activity from Cladosporium fungus sp. 501-7w. Biosci. Biotechnol. Biochem. 1998, 62, 1815-1818. [CrossRef]

9. Li, X.D.; Li, X.; Li, X.M.; Xu, G.M.; Liu, Y.; Wang, B.G. 20-Nor-isopimarane epimers produced by Aspergillus wentii SD-310, a fungal strain obtained from deep sea sediment. Mar. Drugs 2018, 16, 440. [CrossRef]

10. Yang, S.Q.; Li, X.M.; Li, X.; Chi, L.P.; Wang, B.G. Two New Diketomorpholine Derivatives and a New Highly Conjugated Ergostane-Type Steroid from the Marine Algal-Derived Endophytic Fungus Aspergillus alabamensis EN-547. Mar. Drugs 2018, 16, 114. [CrossRef]

11. Li, H.L.; Li, X.M.; Mándi, A.; Antus, S.; Li, X.; Zhang, P.; Liu, Y.; Kurtán, T.; Wang, B.G. Characterization of cladosporols from the marine algal-derived endophytic fungus Cladosporium cladosporioides EN-399 and configurational revision of the previously reported cladosporol derivatives. J. Org. Chem. 2017, 82, 9946-9954. [CrossRef] [PubMed]

12. Zhu, M.L.; Gao, H.Q.; Wu, C.M.; Zhu, T.J.; Che, Q.; Gu, Q.Q.; Guo, P.; Li, D.H. Lipid-lowering polyketides from a soft coral-derived fungus Cladosporium sp. TZP29. Bioorg. Med. Chem. Lett. 2015, 25, 3606-3609. [CrossRef]

13. Smith, C.J.; Abbanat, D.; Bernan, V.S.; Maiese, W.M.; Greenstein, M.; Jompa, J.; Tahir, A.; Ireland, C.M. Novel polyketide metabolites from a species of marine fungi. J. Nat. Prod. 2000, 63, 142-145. [CrossRef]

14. Franck, X.; Araujo, M.E.V.; Jullian, J.C.; Hocquemiller, R.; Figadère, B. Synthesis and structure determination of iso-cladospolide B. Tetrahedron Lett. 2001, 42, 2801-2803. [CrossRef]

15. Gesner, S.; Cohen, N.; Ilan, M.; Yarden, O.; Carmeli, S. Pandangolide 1a, a metabolite of the sponge-associated fungus Cladosporium sp., and the absolute stereochemistry of pandangolide 1 and iso-cladospolide B. J. Nat. Prod. 2005, 68, 1350-1353. [CrossRef]

16. Corey, E.J.; Ulrich, P.; Fitzpatrick, J.M. A stereoselective synthesis of ( \pm )-11-Hydroxy-trans-8-dodecenoic acid lactone, a naturally occurring macrolide from Cephalosporium recifei. J. Am. Chem. Soc. 1976, 98, 222-224. [CrossRef]

17. Rodphaya, D.; Sekiguchi, J.; Yamada, Y. New macrolides from Penicillium Urticae mutant S11R59. J. Antibiot. 1986, 39, 629-635. [CrossRef]

18. Sun, P.; Xu, D.X.; Mándi, A.; Kurtán, T.; Li, T.J.; Schulz, B.; Zhang, W. Structure, absolute configuration, and conformational study of 12-membered macrolides from the fungus Dendrodochium sp. associated with the sea cucumber Holothuria nobilis selenka. J. Org. Chem. 2013, 78, 7030-7047. [CrossRef]

19. Ohtani, I.; Kusumi, T.; Kashman, Y.; Kakisawa, H. High-field FT NMR application of Mosher's method. The absolute configurations of marine terpenoids. J. Am. Chem. Soc. 1991, 113, 4092-4096. [CrossRef]

20. Calculator Plugins Were Used for Structure Property Prediction and Calculation, Marvin 5.9.2, 2012, ChemAxon. Available online: http://www.chemaxon.com (accessed on 31 August 2018).

21. Frisch, M.J.; Trucks, G.W.; Schlegel, H.B.; Scuseria, G.E.; Robb, M.A.; Cheeseman, J.R.; Scalmani, G.; Barone, V.; Mennucci, B.; Petersson, G.A.; et al. Gaussian 09, Revision, C.01; Gaussian, Inc.: Wallingford, CT, USA, 2010.

22. Bruhn, T.; Hemberger, Y.; Schaumloffel, A.; Bringmann, G. SpecDis, Version 1.51; University of Wuerzburg: Würzburg, Germany, 2011.

23. Trost, B.M.; Aponick, A. Palladium-catalyzed asymmetric allylic alkylation of meso- and $d l$-1,2-divinylethylene carbonate. J. Am. Chem. Soc. 2006, 128, 3931-3933. [CrossRef]

24. Reddy, C.R.; Rao, N.N.; Sujitha, P.; Kumar, C.G. Protecting group-free syntheses of $(4 S, 5 S, 11 R)-$ and $(4 S, 5 S, 11 S)$-iso-Cladospolide B and their biological evaluation. Synthesis 2012, 44, 1663-1666. [CrossRef]

25. Crystallographic data of compounds $\mathbf{3}$ and $\mathbf{6}$ have been deposited in the Cambridge Crystallographic Data Centre as CCDC 1889697 and 1889726, respectively. 2019. Available online: http://www.ccdc.cam.ac.uk/ datarequest/cif (accessed on 31 March 2019).

26. Sheldrick, G.M. SADABS, Software for Empirical Absorption Correction; University of Gottingen: Gottingen, Germany, 1996.

27. Sheldrick, G.M. SHELXTL, Structure Determination Software Programs; Bruker Analytical X-ray System Inc.: Madison, WI, USA, 1997. 
28. Sheldrick, G.M. SHELXL-97 and SHELXS-97, Program for X-ray Crystal Structure Solution and Refinement; University of Göttingen: Göttingen, Germany, 1997.

29. Ellman, G.L.; Courtney, K.D.; Andres Jr, V.; Featherstone, R.M. A new and rapid colorimetric determination of acetylcholinesterase activity. Biochem. Pharmacol. 1961, 7, 88-95. [CrossRef]

30. Pierce, C.G.; Uppuluri, P.; Tristan, A.R.; Wormley Jr, F.L.; Mowat, E.; Ramage, G.; Lopez-Ribot, J.L. A simple and reproducible 96-well plate-based method for the formation of fungal biofilms and its application to antifungal susceptibility testing. Nat. Protoc. 2008, 3, 1494-1500. [CrossRef]

(C) 2019 by the authors. Licensee MDPI, Basel, Switzerland. This article is an open access article distributed under the terms and conditions of the Creative Commons Attribution (CC BY) license (http://creativecommons.org/licenses/by/4.0/). 

Article

\title{
Altercrasins A-E, Decalin Derivatives, from a Sea-Urchin-Derived Alternaria sp.: Isolation and Structural Analysis Including Stereochemistry
}

\author{
Takeshi Yamada $^{1, *}$, Asumi Tanaka ${ }^{1}$, Tatsuo Nehira ${ }^{2}$, Takumi Nishii ${ }^{1}$ and Takashi Kikuchi ${ }^{1}$ \\ 1 Department of Medicinal Molecular Chemistry, Osaka University of Pharmaceutical Sciences, 4-20-1, \\ Nasahara, Takatsuki, Osaka 569-1094, Japan; ichigo-ame.xxx@ezweb.ne.jp (A.T.); \\ n.t.rokusyo@i.softbank.jp (T.N.); t.kikuchi@gly.oups.ac.jp (T.K.) \\ 2 Graduate School of Integrated Arts and Sciences, Hiroshima University, 1-7-1 Kagamiyama, \\ Higashi-Hiroshima 739-8521, Japan; tnehira@hiroshima-u.ac.jp \\ * Correspondence: yamada@gly.oups.ac.jp; Tel./Fax: +81-726-90-1085
}

Received: 25 March 2019; Accepted: 9 April 2019; Published: 11 April 2019

\begin{abstract}
In order to find out the seeds of antitumor agents, we focused on potential bioactive materials from marine-derived microorganisms. Marine products include a number of compounds with unique structures, some of which may exhibit unusual bioactivities. As a part of this study, we studied metabolites of a strain of Alternaria sp. OUPS-117D-1 originally derived from the sea urchin Anthocidaris crassispina, and isolated five new decalin derivatives, altercrasins A-E (1-5). The absolute stereostructure of altercrasins A (1) had been decided by chemical transformation and the modified Mosher's method. In this study, four decalin derivatives, altercrasins B-E (2-5) were purified by silica gel chromatography, and reversed phase high-performance liquid chromatography (RP HPLC), and their structures were elucidated on the basis of 1D and 2D nuclear magnetic resonance (NMR) spectroscopic analyses. The absolute configuration of them were deduced by the comparison with 1 in the NMR chemical shifts, NOESY correlations, and electronic circular dichroism (ECD) spectral analyses. As a result, we found out that compound pairs of $1 / 2$ and $4 / 5$ were respective stereoisomers. In addition, their cytotoxic activities using murine P388 leukemia, human HL-60 leukemia, and murine L1210 leukemia cell lines showed that 4 and $\mathbf{5}$ exhibit potent cytotoxicity, in especially, the activity of 4 was equal to that of 5-fluorouracil.
\end{abstract}

Keywords: altercrasins; Alternaria sp.; Anthocidaris crassispina; decalin derivatives; cytotoxicity

\section{Introduction}

Marine organisms are a potential prolific source of highly bioactive secondary metabolites with unique structures that may serve as useful seeds for the development of new chemotherapy agents $[1,2]$. Previously, our group has focused on potential new antitumor materials from marine-derived microorganisms that produce several compounds bearing unique structures [3-5]. As a part of this study, metabolites from the fungus Alternaria sp. OUPS-117D-1 originally obtained from the sea urchin Anthocidaris crassispina were examined, and a new compound designated as altercrasin A (1) (Figure 1) was isolated. As has been reported previously, $\mathbf{1}$ was a cytochalasin-like decalin derivative with spirotetramic acid [6]. Previous reports have also introduced delaminomycins [7] isolated from Streptomyces albulus; lucensimycins [8-10] isolated from Streptomyces lusensis, fusarisetin A [11-13] isolated from Fusarium sp., and diaporthichalasin [14,15] isolated from Diaporte sp. as metabolites with a similar decalin derivative. The absolute configuration of this class with a spiro-lactam or -lactone cannot be experimentally determined unless a good single crystal is obtained [11]. However, in a previously reported study for the absolute stereostructure of $\mathbf{1}$, our group has successfully determined 
it by experiments via a chemical transformation [6]. Our continuous search for cytotoxic metabolites from this fungal strain afforded four new decalin derivatives designated as altercrasins B-E (2-5), respectively (Figure 1). As these were minor components, the above-mentioned method was not used to elucidate the stereostructures. In this study, the chiral centers in these metabolites were assigned by NMR and ECD spectral analyses.

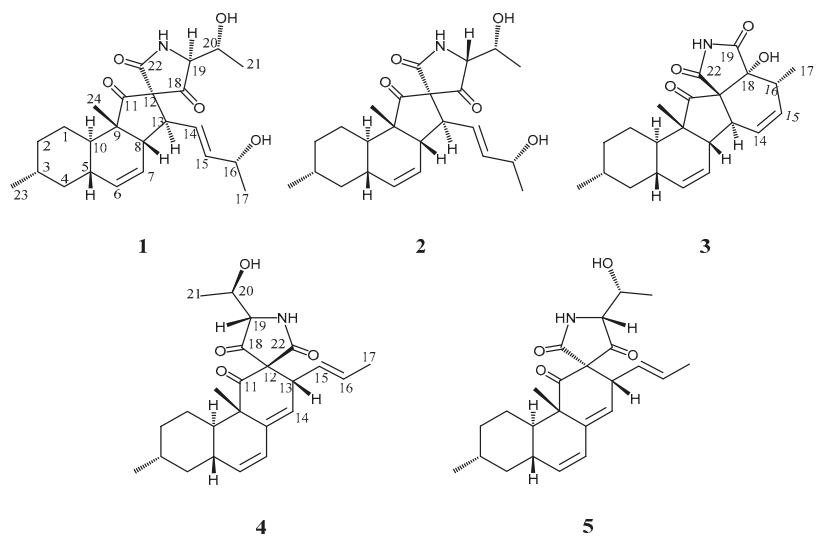

Figure 1. Structures of altercrasins A-E (1-5).

\section{Results and Discussion}

Alternaria sp., a microorganism from A. crassispina, was cultured at $27{ }^{\circ} \mathrm{C}$ for 6 weeks in a medium (70 L) containing $1 \%$ glucose, $1 \%$ malt extract, and $0.05 \%$ peptone in artificial seawater adjusted to $\mathrm{pH}$ 7.5. After incubation, the EtOAc extract of the culture filtrate was purified via bioassay-directed fractionation by using a stepwise combination of silica-gel column and Sephadex LH-20 chromatography, followed by reverse-phase HPLC, affording altercrasins A (1) (10.3 mg, 0.020\%), B (2) (6.5 mg, 0.012\%), C (3) (4.6 mg, 0.009\%), D (4) (1.3 mg, 0.002\%), and E (5) (5.3 mg, 0.010\%) as pale yellow oils.

As it has been observed for previously reported 1 [6], altercrasin B (2) also exhibited the molecular formula $\mathrm{C}_{24} \mathrm{H}_{33} \mathrm{NO}_{5}$ as established by the $[\mathrm{M}+\mathrm{Na}]^{+}$peak in HRFABMS. The IR spectrum exhibited absorption bands at 3478, 1720, and $1710 \mathrm{~cm}^{-1}$ characteristic of hydroxyl and carbonyl groups. The close inspection of the ${ }^{1} \mathrm{H}$ and ${ }^{13} \mathrm{C}$ NMR spectra of $\mathbf{2}$ (Table 1 and Table S1) by using distortionless enhancement by polarization transfer (DEPT) and ${ }^{1} \mathrm{H}-{ }^{13} \mathrm{C}$ correlation spectroscopy (HMQC) revealed the presence of two secondary methyl groups (C-17 and C-23, respectively); a tertiary methyl (C-24) group; three $\mathrm{sp}^{3}$-hybridized methylene groups (C-1, C-2, and C-4, respectively); six $\mathrm{sp}^{3}$-methine groups (C-3, C-5, C-8, C-10, C-13, and C-16, respectively); two quaternary sp ${ }^{3}$-carbon groups (C-9 and $\mathrm{C}-12$, respectively); four $\mathrm{sp}^{2}$-methine groups (C-6, C-7, C-14, and C-15, respectively); and three carbonyl groups (C-11, C-18, and C-22, respectively), including an amide carbonyl (C-22). The ${ }^{1} \mathrm{H}-{ }^{1} \mathrm{H}$ COSY analysis of 2 led to three partial structures, including a hydroxy butylene group $(\mathrm{H}-13 / \mathrm{H}-14$, $\mathrm{H}-14 / \mathrm{H}-15, \mathrm{H}-15 / \mathrm{H}-16, \mathrm{H}-16 / 16-\mathrm{OH}$, and $\mathrm{H}-16 / \mathrm{H}-17)$ and a hydroxyethyl group (H-19/H-20, $\mathrm{H}-20 / 20-\mathrm{OH}$, and $\mathrm{H}-20 / \mathrm{H}-21$ ), as indicated by the bold-faced lines shown in Figure 2. The key $\mathrm{HMBC}$ correlations shown in Figure 2 verified the connection of these three units and the remaining functional groups, indicating that the planar structure of $\mathbf{2}$ is the same as that of $\mathbf{1}$. 


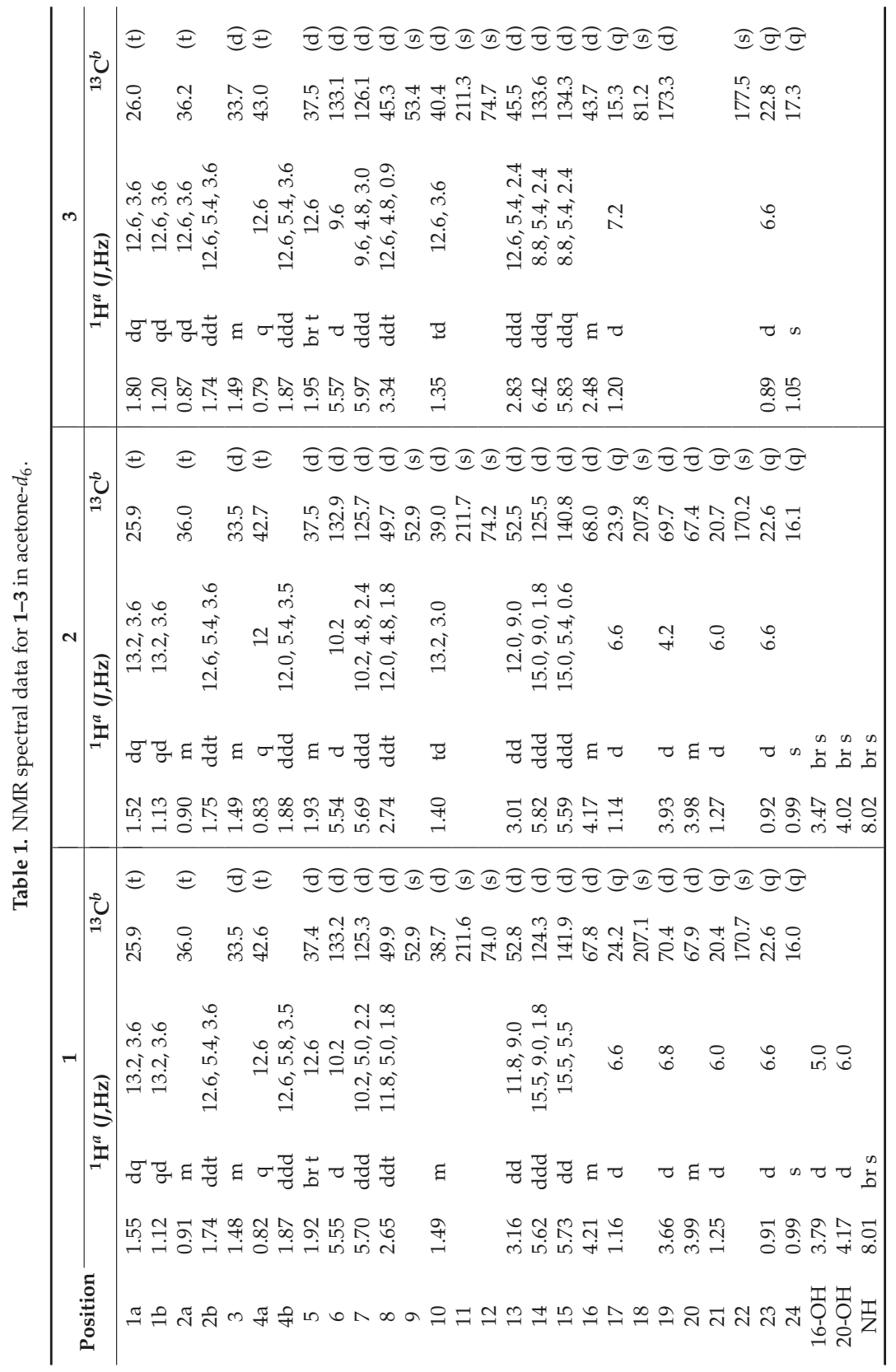




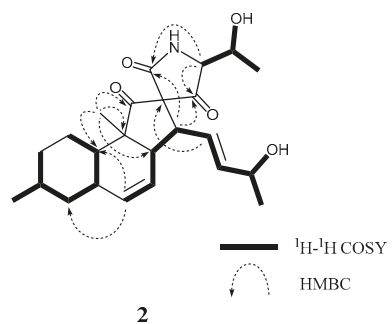

Figure 2. Typical 2D NMR correlations in 2.

The stereochemistry of $\mathbf{2}$ was deduced from NOESY experiments and the comparison of NMR and ECD spectral data with $\mathbf{1}$, where the absolute configuration of $\mathbf{1}$ was determined by the application of the modified Mosher's method after the NOESY experiment of the acetonide derivative following the stereoselective reduction at the carbonyl C-18 group in $1 .{ }^{4}$ The observed NOESY correlations of 2 (H-1 $\beta / \mathrm{H}-3, \mathrm{H}-1 \beta / \mathrm{H}-5, \mathrm{H}-1 \beta / \mathrm{H}-24, \mathrm{H}-5 / \mathrm{H}-24, \mathrm{H}-8 / \mathrm{H}-14, \mathrm{H}-8 / \mathrm{H}-24$, and $\mathrm{H}-10 / \mathrm{H}-13)$ revealed that the relative configuration of the decalin moiety is the same as that of $\mathbf{1}$; i.e., $\mathbf{2}$ was a diastereomer of 1 at C-12, C-16, C-19, or C-20. In ${ }^{1} \mathrm{H}$ NMR spectrum of 2 (Table 1 and Table S1), the general features closely resembled those of $\mathbf{1}$, except for the ${ }^{1} \mathrm{H}$ NMR signals for $\mathrm{H}-19\left(\mathbf{1} ; \delta_{\mathrm{H}} 3.66\right.$ and $\mathbf{2}$; $\left.\left.\delta_{\mathrm{H}} 3.93\right)\right)$. In addition, the coupling constant for the $\mathrm{H}-19$ signal was different $\left(\mathbf{1} ; J_{19,20}=6.8 \mathrm{~Hz}\right.$ and $\mathbf{2}$; $J_{19,20}=4.2 \mathrm{~Hz}$ ). These differences were supposedly related to the magnetic anisotropic effect of the carbonyl group (C-18) that reflected the change of a dihedral angle between $\mathrm{H}-19$ and $\mathrm{H}-20$, indicating that the absolute configuration at $\mathrm{C}-19$ in $\mathbf{2}$ is opposite to that of $\mathbf{1}$. The chemical shifts for the ${ }^{1} \mathrm{H}$ and ${ }^{13} \mathrm{C}$ NMR signals at C-16 and C-20 in 2 resembled those of $\mathbf{1}$, indicative of identical chirality at C-16 and C-20 between 1 and $\mathbf{2}$ (Table 1). On the other hand, the ECD Cotton effects were expected to be induced by the carbonyl groups (C-11, C-18, and C22) around C-12. Hence, the experimental observation that the ECD spectrum of $\mathbf{2}$ shows good agreement with that of $\mathbf{1}$ revealed identical chirality at C-12 between $\mathbf{1}$ and $\mathbf{2}$ (Figure 3). The above evidence suggested that $\mathbf{2}$ is an epimer of $\mathbf{1}$ at C-19.

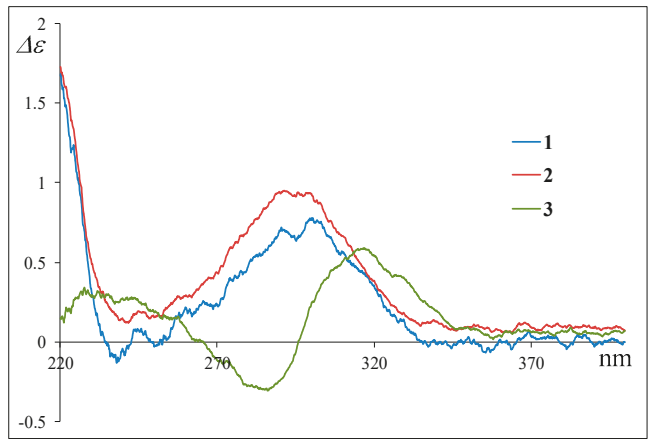

Figure 3. Experimental ECD spectra of 1, 2, and 3.

According to HRFABMS data, altercrasin C (3) was assigned the molecular formula $\mathrm{C}_{22} \mathrm{H}_{27} \mathrm{NO}_{4}$. The general features of its IR spectrum matched those of $\mathbf{1}$ and 2. By the accurate inspection of the NMR spectrum of 3, the signals corresponding to the hydroxyethyl moiety (C-20-C-21) and the carbonyl (C-18) group observed in 1 and 2 were replaced by amide carbonyl (C-19 $\left.\left(\delta_{C} 173.3\right)\right)$ and a quaternary sp $\mathrm{s}^{3}$ carbon groups with a hydroxyl group (C-18 $\left.\left(\delta_{\mathrm{C}} 81.2\right)\right)$ (Table 1 and Table S2). In addition, the geometrical configuration of the side-chain olefin moiety (C-14 to C-15) as cis from the ${ }^{1} \mathrm{H}$ NMR coupling constant $\left(J_{14}, 158.8 \mathrm{~Hz}\right)$ was revealed to be less than that of $\mathbf{1}\left(J_{14,15} 15.5 \mathrm{~Hz}\right)$. The above evidences and the ${ }^{1} \mathrm{H}-{ }^{1} \mathrm{H}$ COSY and HMBC correlation shown in Figure 4 and Table S3 
led to the planar structure of 3 , which had a cyclic imide. For the stereochemistry of 3 , the NOESY correlations (H-1/H-3, H-1/H-5, H-1/H-24, H-4/H-10, H-5/H-24, H-8/H-24, and H-10/H-13) for the decalin moiety revealed that the relative configurations among C-3, C-5, C8, C-9, C-10, and C-13 are the same as $\mathbf{1}$ and 2. In addition, the NOESY correlation between $\mathrm{H}-13$ and $\mathrm{H}-17$ revealed that the 16-methyl group is oriented cis to H-13 (Figure 5). The absolute configurations in the decalin moiety were hypothesized as those of the above compounds in terms of the biosynthetic pathway. To determine the absolute configuration of the remaining chiral centers (C-12 and C-18), the ECD spectrum of 3 following a conformational consideration by the NOESY experiment and the building of an HGS molecular model was recorded. For all possible combinations, 3a (12S, 18R), 3b (12S, $18 S), 3 \mathbf{c}(12 R, 18 R)$, and $3 \mathrm{~d}(12 R, 18 S)$ (Figure 6), the trans ring junction at C-12 and C-18 such as $3 \mathbf{a}$ and $3 \mathrm{~d}$ led to a large distortion of the five-membered cyclic imide; hence, the possibility of 3 exhibiting the $3 \mathbf{a}$ and $\mathbf{3 d}$ stereostructures is excluded in addition to some contradiction of NOESY correlation; i.e., the correlation between $\mathrm{H}-17$ and $\mathrm{H}-13$ should not be observed in 3a. In ECD spectra of 1,2 , and 3 , the Cotton effect at $285 \mathrm{~nm}$ corresponded to the carbonyl groups ( $n \rightarrow \pi^{*}$ interaction); hence, the absolute configuration at C-12 is assigned (Figure 3). The ECD spectra of 3 showed a negative Cotton effect at $285 \mathrm{~nm}$; hence, the absolute configuration at C-12 in 3 is deduced to be $12 R$, i.e., 3 exhibited the stereostructure of $3 \mathbf{c}$.

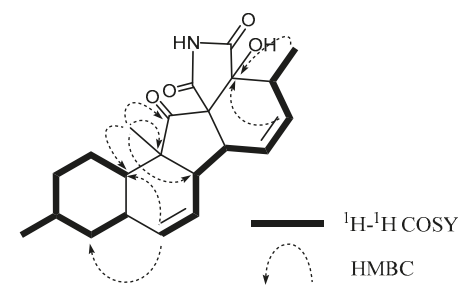

3

Figure 4. Typical 2D NMR correlations in 3.

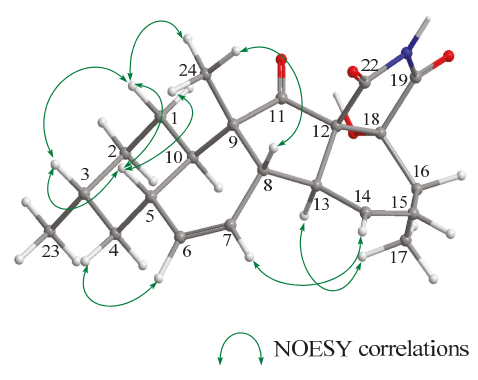

Figure 5. Key NOESY correlations in 3.

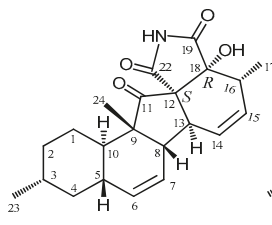

$3 \mathbf{a}$

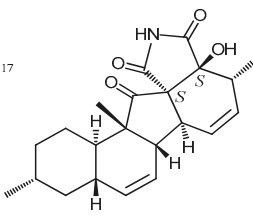

$\mathbf{3 b}$

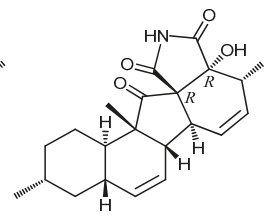

$3 c$

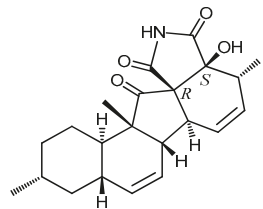

$3 d$

Figure 6. Four plausible structures of 3.

Altercrasins D (4) and E (5) were assigned the same molecular formula $\mathrm{C}_{24} \mathrm{H}_{31} \mathrm{NO}_{4}$ based on the deduction according to HRFABMS data. ${ }^{1} \mathrm{H}$ and ${ }^{13} \mathrm{C}$ NMR spectra of 4 and 5 revealed similar 
features except that the differences for the chemical shift between 4 (proton signals: $\mathrm{H}-1 \alpha\left(\delta_{\mathrm{H}} 1.67\right)$, $\mathrm{H}-10\left(\delta_{\mathrm{H}} 1.70\right), \mathrm{H}-13\left(\delta_{\mathrm{H}} 3.71\right), \mathrm{H}-14\left(\delta_{\mathrm{H}} 5.52\right)$, and H-19 $\left(\delta_{\mathrm{H}} 3.49\right)$; carbon signals: C-11 $\left(\delta_{\mathrm{C}} 208.4\right), \mathrm{C}-12$ $\left(\delta_{\mathrm{C}} 70.5\right), \mathrm{C}-13\left(\delta_{\mathrm{C}} 43.6\right), \mathrm{C}-14\left(\delta_{\mathrm{C}} 124.6\right), \mathrm{C}-18\left(\delta_{\mathrm{C}} 208.4\right)$, and C-22 $\left.\left(\delta_{\mathrm{C}} 168.1\right)\right)$ and 5 (proton signals: $\mathrm{H}-1 \alpha\left(\delta_{\mathrm{H}} 1.91\right), \mathrm{H}-10\left(\delta_{\mathrm{H}} 1.37\right), \mathrm{H}-13\left(\delta_{\mathrm{H}} 3.96\right), \mathrm{H}-14\left(\delta_{\mathrm{H}} 5.70\right)$, and H-19 $\left(\delta_{\mathrm{H}} 3.81\right)$; carbon signals: C-11 $\left(\delta_{\mathrm{C}} 205.2\right), \mathrm{C}-12\left(\delta_{\mathrm{C}} 72.7\right), \mathrm{C}-13\left(\delta_{\mathrm{C}} 41.5\right), \mathrm{C}-14\left(\delta_{\mathrm{C}} 126.9\right), \mathrm{C}-18\left(\delta_{\mathrm{C}} 204.7\right)$, and C-22 $\left.\left(\delta_{\mathrm{C}} 170.7\right)\right)$ were observed (Table 2, Tables S3 and S4). Analyses of HMBC correlations confirmed that 4 and $\mathbf{5}$ have the same planar structure (Figure 7). In the NOESY experiments of 4 and $\mathbf{5}$ (Table 2, Tables S3 and S4), the observed correlations clearly indicated their homologous stereochemistry except for the spiro $\gamma$-lactam moiety; i.e., diastereomeric relationship at C-12, C-19, or C-20 between 4 and 5 was revealed.

Table 2. NMR spectral data for 4 and 5 in acetone- $d_{6}$.

\begin{tabular}{|c|c|c|c|c|c|c|c|c|c|c|}
\hline \multirow{3}{*}{$\begin{array}{c}\text { Position } \\
1 \alpha\end{array}$} & \multicolumn{5}{|c|}{4} & \multicolumn{5}{|c|}{5} \\
\hline & \multicolumn{3}{|c|}{${ }^{1} \mathrm{H}^{a}(J, \mathrm{~Hz})$} & \multicolumn{2}{|c|}{${ }^{13} C^{b}$} & \multicolumn{3}{|c|}{${ }^{1} \mathrm{H}^{a}(J, \mathrm{~Hz})$} & \multicolumn{2}{|c|}{${ }^{13} C^{b}$} \\
\hline & 1.67 & $\mathrm{~m}$ & & 27.6 & $(\mathrm{t})$ & 1.91 & $\mathrm{dq}$ & $12.6,3.6$ & 28.0 & $(t)$ \\
\hline $1 \beta$ & 1.20 & $\mathrm{qd}$ & $12.6,3.6$ & & & 1.20 & qd & $12.6,3.6$ & & \\
\hline $2 \alpha$ & 0.85 & $\mathrm{qd}$ & $12.6,3.6$ & 36.1 & $(\mathrm{t})$ & 0.90 & $\mathrm{~m}$ & & 36.2 & $(\mathrm{t})$ \\
\hline $2 \beta$ & 1.72 & $\mathrm{~m}$ & & & & 1.73 & $\mathrm{ddt}$ & $11.4,5.4,3.6$ & & \\
\hline 3 & 1.49 & $\mathrm{~m}$ & & 33.5 & (d) & 1.49 & $\mathrm{~m}$ & & 33.5 & (d) \\
\hline $4 \alpha$ & 0.79 & $\mathrm{q}$ & 12.6 & 42.6 & $(\mathrm{t})$ & 0.80 & $q$ & 12 & 42.9 & $(\mathrm{t})$ \\
\hline $4 \beta$ & 1.85 & ddd & $12.6,5.4,3.6$ & & & 1.87 & ddd & $12.0,5.8,3.5$ & & \\
\hline 5 & 2.08 & $\mathrm{~m}$ & & 39.1 & (d) & 2.09 & $\mathrm{~m}$ & & 38.6 & (d) \\
\hline 6 & 5.48 & $\mathrm{~d}$ & 10.2 & 133.3 & (d) & 5.49 & $\mathrm{~d}$ & 10.2 & 133.5 & (d) \\
\hline 7 & 6.04 & $\mathrm{dd}$ & $10.2,3.0$ & 127.7 & (d) & 6.07 & $\mathrm{dd}$ & $10.2,3.0$ & 127.4 & (d) \\
\hline 8 & & & & 141.5 & (s) & & & & 140.1 & (s) \\
\hline 9 & & & & 50.7 & (s) & & & & 50.6 & (s) \\
\hline 10 & 1.70 & $\mathrm{~m}$ & & 44.7 & (d) & 1.37 & $\mathrm{td}$ & $12.6,3.6$ & 45.3 & (d) \\
\hline 11 & & & & 208.4 & (s) & & & & 205.2 & (s) \\
\hline 12 & & & & 70.5 & (s) & & & & 72.7 & (s) \\
\hline 13 & 3.71 & d & 9.6 & 43.6 & (d) & 3.96 & $\mathrm{~d}$ & 9 & 41.5 & (d) \\
\hline 14 & 5.52 & $\mathrm{~d}$ & 1.8 & 124.6 & (d) & 5.70 & $\mathrm{~d}$ & 1.8 & 126.9 & (d) \\
\hline 15 & 5.37 & ddq & $16.8,9.6,1.8$ & 128.4 & (d) & 5.37 & ddq & $16.8,9.0,1.8$ & 129.4 & (d) \\
\hline 16 & 5.57 & $\mathrm{dq}^{\mathrm{I}}$ & $16.8,6.6$ & 131.0 & (d) & 5.62 & $\mathrm{dq}$ & $16.8,6.6$ & 129.9 & (d) \\
\hline 17 & 1.62 & $\mathrm{~d}$ & 6.6 & 18.0 & (q) & 1.59 & $\mathrm{~d}$ & 6.6 & 17.9 & (q) \\
\hline 18 & & & & 208.4 & (s) & & & & 204.7 & (s) \\
\hline 19 & 3.49 & $\mathrm{~d}$ & 7.2 & 69.9 & (d) & 3.81 & $\mathrm{~d}$ & 4.8 & 68.9 & (d) \\
\hline 20 & 3.99 & $\mathrm{~m}$ & & 68.1 & (d) & 3.90 & $\mathrm{~m}$ & & 67.0 & (d) \\
\hline 21 & 1.28 & $\mathrm{~d}$ & 6.6 & 20.2 & (q) & 1.29 & $\mathrm{~d}$ & 6.0 & 20.8 & (q) \\
\hline 22 & & & & 168.1 & (s) & & & & 170.7 & (s) \\
\hline 23 & 0.89 & d & 6.6 & 22.6 & (q) & 0.89 & $\mathrm{~d}$ & 6.6 & 22.6 & (q) \\
\hline 24 & 1.12 & $\mathrm{~s}$ & & 17.4 & (q) & 1.12 & $\mathrm{~s}$ & & 16.6 & (q) \\
\hline $20-\mathrm{OH}$ & 4.06 & br s & & & & 4.02 & $\mathrm{~d}$ & 6.0 & & \\
\hline $\mathrm{NH}$ & 7.88 & br s & & & & 7.86 & br s & & & \\
\hline
\end{tabular}

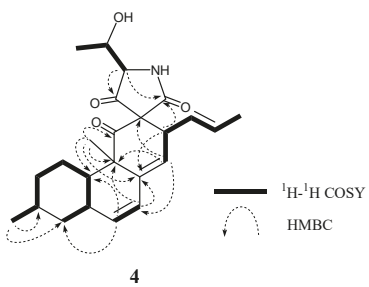

Figure 7. Typical 2D NMR correlations in 4.

Their absolute stereostructure was considered to be based on the relationship between the ECD Cotton effects and the absolute configuration at C-12 as described above. The Cotton effects at $285 \mathrm{~nm}$ in the CD spectra of 4 and 5 clearly revealed the absolute configuration at C-12, i.e., 4 possessed $12 S$, 
and 5 possessed $12 R$ (Figure 8). For the ${ }^{1} \mathrm{H}$ and ${ }^{13} \mathrm{C}$ NMR signals at $\mathrm{C}-20$ in 4 and $\mathbf{5}$, the chemical shifts were in good agreement with those of $\mathbf{1}$ and $\mathbf{2}$. Based on this evidence and the fact that these were isolated from the same fungal metabolites, we guessed that 4 and 5 exhibit a $20 R$ configuration as $\mathbf{1}$ and 2. On the other hand, the ${ }^{1} \mathrm{H}$ NMR signals for $\mathrm{H}-19$ in $\mathbf{4}$ and $\mathbf{5}$ demonstrated the same difference in the chemical shifts and spin-spin coupling constants $\left(4: \delta_{\mathrm{H}} 3.49(7.2 \mathrm{~Hz})\right.$ and $\left.5: \delta_{\mathrm{H}} 3.81(4.8 \mathrm{~Hz})\right)$ as those of 1 and 2 (Tables 1 and 2); hence, the dihedral angle between H-19 and H-20 in 4 and 5 is thought to be the same as those of $\mathbf{1}$ and 2, respectively, i.e., $\mathbf{4}$ and $\mathbf{5}$ exhibited the $19 S$ and $19 R$ configurations, respectively. Thus, the absolute configuration of $4(12 S, 19 S, 20 R)$ and $5(12 R, 19 R, 20 R)$ is proposed. These stereostructural hypotheses will be positively supported by synthetic research or X-ray crystal structure analysis in the future.

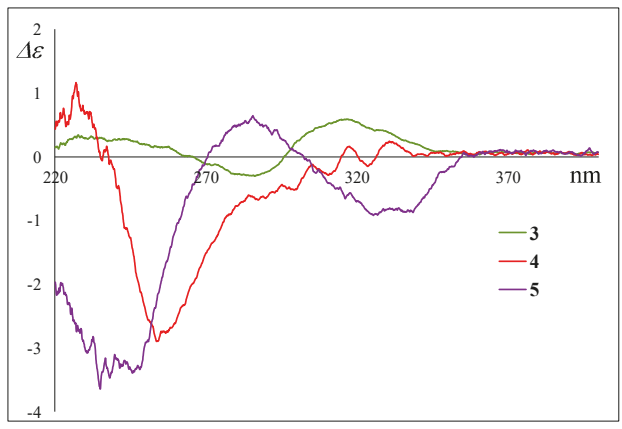

Figure 8. Experimental ECD spectra of 4 and 5.

In this study, the cancer cell growth inhibitory property of the metabolites was examined using murine P388 leukemia, human HL-60 leukemia, and murine L1210 leukemia cell lines. Table 3 summarizes the results. 4 and 5 bearing a diene moiety (C-6 to C-8) exhibited significant cytotoxic activity against these cancer cells. In particular, the activity of 4 was equal to that of 5-fluorouracil. Contrary to our expectations, the difference in the stereochemistry was not related to the activity. Currently, investigation of related compounds isolated from this fungal metabolite is underway, as well as their structure-activity relationships.

Table 3. Cytotoxicity assay against P388 and HL-60 and L1210 cell lines.

\begin{tabular}{cccc}
\hline Compounds & $\begin{array}{c}\text { Cell line P388 } \\
\mathrm{IC}_{\mathbf{5 0}}(\boldsymbol{\mu M})^{a}\end{array}$ & $\begin{array}{c}\text { Cell line HL-60 } \\
\mathrm{IC}_{\mathbf{5 0}}(\boldsymbol{\mu M})^{a}\end{array}$ & $\begin{array}{c}\text { Cell line L1210 } \\
\text { IC }_{\mathbf{5 0}}(\boldsymbol{\mu M})^{a}\end{array}$ \\
\hline $\mathbf{1}$ & 36.2 & 21.5 & 22.1 \\
$\mathbf{2}$ & 20.0 & 12.1 & 8.0 \\
$\mathbf{3}$ & 61.2 & 41.6 & 27.1 \\
$\mathbf{4}$ & 9.7 & 6.1 & 8.4 \\
$\mathbf{5}$ & 15.5 & 6.2 & 10.3 \\
5-Fluorouracil $^{b}$ & 7.2 & 4.5 & 1.1 \\
\hline
\end{tabular}

${ }^{a}$ DMSO was used as vehicle. ${ }^{b}$ Positive control.

\section{Materials and Methods}

\subsection{General Experimental Procedures}

NMR spectra were recorded on an Agilent-NMR-vnmrs (Agilent Technologies, Santa Clara, CA, USA) 600 with tetramethylsilane (TMS) as an internal reference. FABMS was recorded using a JEOL JMS-7000 mass spectrometer (JEOL, Tokyo, Japan). IR spectra was recorded on a JASCOFT/IR-680 Plus (Tokyo, Japan). Optical rotations were measured using a JASCO DIP-1000 digital polarimeter (Tokyo, Japan). Silica gel 60 (230-400 mesh, Nacalai Tesque, Inc., Kyoto, Japan) was used for 
column chromatography with medium pressure. ODS HPLC was run on a JASCO PU-1586 (Tokyo, Japan) equipped with a differential refractometer RI-1531 (Tokyo, Japan) and Cosmosil Packed Column 5C18-MSII $(25 \mathrm{~cm} \times 20 \mathrm{~mm}$ i.d., Nacalai Tesque, Inc., Kyoto, Japan). Analytical TLC was performed on precoated Merck aluminum sheets (DC-Alufolien Kieselgel 60 F254, 0.2 mm, Merck, Darmstadt, Germany) with the solvent system $\mathrm{CH}_{2} \mathrm{Cl}_{2}-\mathrm{MeOH}$ (19:1) (Nacalai Tesque, Inc., Kyoto, Japan), and compounds were viewed under a UV lamp (AS ONE Co., Ltd., Osaka, Japan) and sprayed with $10 \% \mathrm{H}_{2} \mathrm{SO}_{4}$ (Nacalai Tesque, Inc., Kyoto, Japan) followed by heating.

\subsection{Fungal Material}

A strain of Alternaria sp. OUPS-117D-1 was initially isolated from the sea urchin Anthocidaris crassispana, collected in Osaka bay, Japan in May 2010. The fungal strain was identified by Techno Suruga Laboratory Co., Ltd., Shizuoka, Japan. The sea urchin, which wiped its surface with EtOH, was cracked by a scalpel and its inside was applied to the surface of nutrient agar layered in a Petri dish. Serial transfers of one of the resulting colonies provided a pure strain of Alternaria sp.

\subsection{Culturing and Isolation of Metabolites}

The fungal strain was cultured at $27^{\circ} \mathrm{C}$ for six weeks in a liquid medium $(70 \mathrm{~L})$ containing $1 \%$ glucose, $1 \%$ malt extract and $0.05 \%$ pepton in artificial seawater adjusted to $\mathrm{pH} 7.5$. The fungal strain filtrated culture broth was extracted thrice with $\mathrm{MeOH}$ (Nacalai Tesque, Inc., Kyoto, Japan). The combined extracts were evaporated in vacuo to afford a mixture of crude metabolites (52.8 g). The $\mathrm{MeOH}$ extract was chromatographed on a silica gel (Nacalai Tesque, Inc., Kyoto, Japan) column with a $\mathrm{CH}_{2} \mathrm{Cl}_{2}-\mathrm{MeOH}$ (Nacalai Tesque, Inc., Kyoto, Japan) gradient as the eluent. The $\mathrm{MeOH}-\mathrm{CH}_{2} \mathrm{Cl}_{2}$ (5:95) eluate (22.6 g) was chromatographed again on a silica gel column with a hexane-EtOAc-MeOH (Nacalai Tesque, Inc., Kyoto, Japan) gradient as the eluent. The MeOH-EtOAc (2:98 and 5:95) eluate (F1 (1.9 g), F2 (1.3 g), respectively) were chromatographed on LH-20 (GE Healthcare Japan, Tokyo, Japan) using $\mathrm{MeOH}-\mathrm{CH}_{2} \mathrm{Cl}_{2}$ (1:1) as the eluent. The fraction exhibiting cytotoxicity from F1 (105.1 mg) was purified by HPLC using $\mathrm{MeOH}-\mathrm{H}_{2} \mathrm{O}$ (80:20) as the eluent to afford 3 (4.6 mg), 4 (1.3 mg), and $5(5.3 \mathrm{mg})$. The fraction exhibiting cytotoxicity from F2 $(794.5 \mathrm{mg})$ was purified by HPLC using $\mathrm{MeOH}-\mathrm{H}_{2} \mathrm{O}(80: 20)$ as the eluent to afford $\mathbf{1}(10.3 \mathrm{mg})$ and $2(6.5 \mathrm{mg})$.

Altercrasin A (1). colorless oil; IR (film) $v_{\max } 3345,17301671 \mathrm{~cm}^{-1}$; NMR data, see Table 1 and Table S0, and the previous report ${ }^{4}$; HRFABMS [M + H] ${ }^{+} \mathrm{m} / \mathrm{z} 416.2436$ (calcd for $\mathrm{C}_{24} \mathrm{H}_{34} \mathrm{NO}_{5}$ : 416.2437).

Altercrasin B (2). colorless oil; IR (film) $v_{\max } 3368,17291701 \mathrm{~cm}^{-1}$; NMR data, see Table 1 and Table S1; HRFABMS [M + H] ${ }^{+} \mathrm{m} / z 416.2430$ (calcd for $\mathrm{C}_{24} \mathrm{H}_{34} \mathrm{NO}_{5}: 416.2437$ ).

Altercrasin C (3). colorless oil; IR (film) $v_{\max } 3478,17201710 \mathrm{~cm}^{-1}$; NMR data, see Table 1 and Table S2; HRFABMS [M + Na] $]^{+} \mathrm{m} / z 392.1839$ (calcd for $\mathrm{C}_{22} \mathrm{H}_{27} \mathrm{NO}_{4} \mathrm{Na}$ : 392.1837).

Altercrasin D (4). colorless oil; IR (film) $v_{\max } 3318,2917,1693 \mathrm{~cm}^{-1}$; NMR data, see Table 2 and Table S3; HRFABMS [M + H] $]^{+} \mathrm{m} / z 398.2332$ (calcd for $\mathrm{C}_{24} \mathrm{H}_{32} \mathrm{NO}_{4}$ : 398.2332).

Altercrasin E (5). colorless oil; IR (film) $v_{\max } 3318,29181701 \mathrm{~cm}^{-1}$; NMR data, see Table 2 and Table S4; HRFABMS [M + H] ${ }^{+} \mathrm{m} / z 398.2332$ (calcd for $\mathrm{C}_{24} \mathrm{H}_{32} \mathrm{NO}_{4}$ : 398.2332).

\subsection{Assay for Cytotoxicity}

Cytotoxic activities of 1-5 and 5-fluorouracil were examined with the 3-(4,5-dimethyl-2-thiazolyl)2,5-diphenyl-2H-tetrazolium bromide (MTT) method. P388, HL-60, and L1210 cells were cultured in RPMI 1640 Medium ( $10 \%$ fetal calf serum) at $37^{\circ} \mathrm{C}$ in $5 \% \mathrm{CO}_{2}$. The test materials were dissolved in dimethyl sulfoxide (DMSO) to give a concentration of $10 \mathrm{mM}$, and the solution was diluted with the Essential Medium to yield concentrations of 200, 20, and $2 \mu \mathrm{M}$, respectively. Each solution was combined with each cell suspension $\left(1 \times 10^{-5}\right.$ cells $\left./ \mathrm{mL}\right)$ in the medium, respectively. After incubating at $37^{\circ} \mathrm{C}$ for $72 \mathrm{~h}$ in $5 \% \mathrm{CO}_{2}$, grown cells were labeled with $5 \mathrm{mg} / \mathrm{mL}$ MTT in phosphate-buffered saline (PBS), and the absorbance of formazan dissolved in $20 \%$ sodium dodecyl sulfate (SDS) in $0.1 \mathrm{~N} \mathrm{HCl}$ was measured at $540 \mathrm{~nm}$ with a microplate reader (MTP-310, CORONA electric). Each absorbance values 
were expressed as percentage relative to that of the control cell suspension that was prepared without the test substance using the same procedure as that described above. All assays were performed three times, semilogarithmic plots were constructed from the averaged data, and the effective dose of the substance required to inhibit cell growth by $50 \%\left(\mathrm{IC}_{50}\right)$ was determined.

\section{Conclusions}

In this study, four new decalin derivatives designated as altercrasins B-E (2-5) were isolated from a strain of Alternaria sp. OUPS-117D-1 originally derived from the sea urchin A. crassispina. Their chemical structures were confirmed by NMR spectral analysis, and their plausible stereochemistry was deduced by considering the NMR chemical shifts and spin-spin coupling constants, as well as the assignment of ECD Cotton effects. As a result of the assay for cytotoxicity, 4 and 5 bearing a diene moiety (C-6 to C-8) exhibited significant cytotoxic activity against these cancer cells, especially the HL-60 cell line. In especially, the activity of 4 was equal to that of 5-fluorouracil.

Supplementary Materials: The following are available online at http:/ /www.mdpi.com/1660-3397/17/4/218/s1, Table S0: Spectral data including 2D NMR data for 1, Table S1: Spectral data including 2D NMR data for 2, Table S2: Spectral data including 2D NMR data for 3, Table S3: Spectral data including 2D NMR data for 4, Table S4: Spectral data including 2D NMR data for 5, Figure S1: ${ }^{1} \mathrm{H}$ and ${ }^{13} \mathrm{C}$ NMR spectrum of $\mathbf{1}$ in acetone- $d_{6}$, Figure S2: ${ }^{1} \mathrm{H}-{ }^{1} \mathrm{H}$ COSY of 1, Figure S3: NOESY of 1, Figure S4: HMQC of 1, Figure S5: HMBC of 1, Figure S6: FABMS of 1, Figure S7: ${ }^{1} \mathrm{H}$ and ${ }^{13} \mathrm{C}$ NMR spectrum of 2 in acetone- $d_{6}$, Figure S8: ${ }^{1} \mathrm{H}_{-}{ }^{1} \mathrm{H}$ COSY of 2, Figure S9: NOESY of 2, Figure S10: HMQC of 2, Figure S11: HMBC of 2, Figure S12: FABMS of 2, Figure S13: ${ }^{1} \mathrm{H}$ and ${ }^{13} \mathrm{C}$ NMR spectrum of 3 in acetone- $d_{6}$, Figure S14: ${ }^{1} \mathrm{H}^{-1} \mathrm{H}$ COSY of 3, Figure S15: NOESY of 3, Figure S16: HMQC of 3, Figure S17: HMBC of 3, Figure S18: FABMS of 3, Figure S19: ${ }^{1} \mathrm{H}$ and ${ }^{13} \mathrm{C}$ NMR spectrum of 4 in acetone- $d_{6}$, Figure S20: ${ }^{1} \mathrm{H}-{ }^{1} \mathrm{H}$ COSY of 4, Figure S21: NOESY of 4, Figure S22: HMQC of 4, Figure S23: HMBC of 4, Figure S24: FABMS of 4, Figure S25: ${ }^{1} \mathrm{H}$ and ${ }^{13} \mathrm{C}$ NMR spectrum of 5 in acetone- $d_{6}$, Figure S26: ${ }^{1} \mathrm{H}-{ }^{1} \mathrm{H}$ COSY of 5, Figure S27: NOESY of 5, Figure S28: HMQC of 5, Figure S29: HMBC of 5, Figure S30: FABMS of 5.

Author Contributions: Conceived and designed the experiments: T.Y., T.N. (Tatsuo Nehira), and T.K.; Performed the experiments: T.Y., A.S., and T.N. (Takumi Nishii); Analyzed the data: T.Y.; and Wrote the paper: T.Y.

Funding: This research received no external funding.

Acknowledgments: We thank Endo (Kanazawa University) for supply of the cancer cells. We are grateful to M. Fujitake and K. Minoura of this university for MS and NMR measurements, respectively.

Conflicts of Interest: The authors declare no conflict of interest.

\section{References}

1. Blunt, J.W.; Copp, B.R.; Keyzers, R.A.; Munro, M.H.G.; Prinsep, M.R. Marine natural products. Nat. Prod. Rep. 2017, 34, 235-294. [CrossRef] [PubMed]

2. Blunt, J.W.; Carroll, A.R.; Copp, B.R.; Davis, R.A.; Keyzers, R.A.; Prinsep, M.R. Marine natural products. Nat. Prod. Rep. 2018, 35, 8-53. [CrossRef] [PubMed]

3. Yamada, T.; Iritani, M.; Ohishi, H.; Tanaka, K.; Minoura, K.; Doi, M.; Numata, A. Pericosines, antitumour metabolites from the sea hare-derived fungus Periconia byssoides. Structures and biological activities. Org. Biomol. Chem. 2007, 5, 3979-3986. [CrossRef] [PubMed]

4. Yamada, T.; Kitada, H.; Kajimoto, T.; Numata, A.; Tanaka, R. The relationship between the CD Cotton effect and the absolute configuration of FD-838 and its seven stereoisomers. J. Org. Chem. 2010, 75, 4146-4153. [CrossRef] [PubMed]

5. Yamada, T.; Umebayashi, Y.; Kawashima, M.; Sugiura, Y.; Kikuchi, T.; Tanaka, R. Determination of the chemical structures of tandyukisins B-D, isolated from a marine sponge-derived fungus. Mar. Drugs 2015, 13, 3231-3240. [CrossRef] [PubMed]

6. Yamada, T.; Kikuchi, T.; Tanaka, R. Altercrasin A, a novel decalin derivative with spirotetramic acid, produced by a sea urchin-derived Alternaria sp. Tetrahedron Lett. 2015, 56, 1229-1232. [CrossRef] 
7. Ueno, M.; Someno, T.; Sawa, R.; Iinuma, H.; Naganawa, H.; Ishizuka, M.; Takeuchi, T. Delaminomycins, novel nonpeptide extracellular matrix receptor antagonist and a new class of potent immunomodulator. II. Physico-chemical properties and structure elucidation of delaminomycin A. J. Antibiotics. 1993, 46, 979-984. [CrossRef]

8. Singh, S.B.; Zink, D.L.; Huber, J.; Genilloud, O.; Salazar, O.; Diez, M.T.; Basilio, A.; Vicente, F.; Byrne, K.M. Discovery of lucensimysin A and B from Streptpmyces lucensis MA7349 using an antisense strategy. Org. Lett. 2006, 8, 5449-5452. [CrossRef] [PubMed]

9. Singh, S.B.; Zink, D.L.; Herath, K.B.; Salazar, O.; Genilloud, O. Discovery and antibacterial activity of lucensimysin C from Streptpmyces lucensis. Tetrahedron Lett. 2008, 49, 2616-2619. [CrossRef]

10. Singh, S.B.; Zink, D.L.; Dorso, K.; Motyl, M.; Salazar, O.; Basilio, A.; Vicente, F.; Byrne, K.M.; Ha, S.; Genilloud, O. Isolation, structure, and antibacterial activities of lucensimysins D-G, discovered from Streptpmyces lucensis MA7349 using an antisense strategy. J. Nat. Prod. 2009, 72, 345-352. [CrossRef] [PubMed]

11. Jang, J.-H.; Asami, Y.; Jang, J.-P.; Kim, S.-O.; Moon, D.O.; Shin, K.-S.; Hashizume, D.; Muroi, M.; Saito, T.; Oh, H.; Kim, B.Y.; et al. Fusarisetin A, an acinar morphogenesis inhibitor from a soil fungus, Fusarium sp. FN080326. J. Am. Chem. Soc. 2011, 133, 6865-6867. [CrossRef] [PubMed]

12. Deng, J.; Zhu, B.; Lu, Z.; Yu, H.; Li, A. Total synthesis of (-)-fusarisetin A and reassignment of the absolute configuration of its natural counterpart. J. Am. Chem. Soc. 2012, 134, 920-923. [CrossRef] [PubMed]

13. Yin, J.; Wang, C.; Kong, L.; Cai, S.; Gao, S. Asymmetric synthesis and biosynthetic implications of (+)-fusarisetin A. Angew. Chem. Int. Ed. 2012, 51, 7786-7789. [CrossRef] [PubMed]

14. Pornpakakul, S.; Roengsumran, S.; Deechangvipart, S.; Petsom, A.; Muangsin, N.; Ngamrojnavanich, N.; Sriubolmas, N.; Chaichit, N.; Ohta, T. Diaporthichalasin, a novel CYP3A4 inhibitor from an endophytic Diaporthe sp. Tetrahedron Lett. 2007, 48, 651-655. [CrossRef]

15. Brown, S.G.; Jansma, M.J.; Hoye, T.R. Case study of empirical and computational chemical shift analyses: reassignment of the relative configuration of phomopsichalasin to that disporthichalasin. J. Nat. Prod. 2012, 75, 1326-1331. [CrossRef] [PubMed]

(C) 2019 by the authors. Licensee MDPI, Basel, Switzerland. This article is an open access article distributed under the terms and conditions of the Creative Commons Attribution (CC BY) license (http:/ / creativecommons.org/licenses/by/4.0/). 


\title{
Natural Bioactive Thiazole-Based Peptides from Marine Resources: Structural and Pharmacological Aspects
}

\author{
Rajiv Dahiya ${ }^{1, *,+}$, Sunita Dahiya ${ }^{2, *,+}$, Neeraj Kumar Fuloria ${ }^{3}$, Suresh Kumar ${ }^{4}$, Rita Mourya ${ }^{5}$, \\ Suresh V. Chennupati ${ }^{6}$, Satish Jankie ${ }^{1}$, Hemendra Gautam ${ }^{7}$, Sunil Singh ${ }^{8}$, \\ Sanjay Kumar Karan ${ }^{9}$, Sandeep Maharaj ${ }^{1}$, Shivkanya Fuloria ${ }^{3}$, Jyoti Shrivastava ${ }^{10}$, \\ Alka Agarwal ${ }^{11}$, Shamjeet Singh ${ }^{1}$, Awadh Kishor ${ }^{12}$, Gunjan Jadon ${ }^{13}$ and Ajay Sharma ${ }^{14}$
}

1 School of Pharmacy, Faculty of Medical Sciences, The University of the West Indies, St. Augustine, Trinidad \& Tobago; Satish.Jankie@sta.uwi.edu (S.J.); Sandeep.Maharaj@sta.uwi.edu (S.M.);

Shamjeet.Singh@sta.uwi.edu (S.S.)

2 Department of Pharmaceutical Sciences, School of Pharmacy, University of Puerto Rico, Medical Sciences Campus, San Juan, PR 00936, USA

3 Department of Pharmaceutical Chemistry, Faculty of Pharmacy, AIMST University, Semeling, Bedong 08100, Kedah, Malaysia; neerajkumar@aimst.edu.my (N.K.F.); shivkanya_fuloria@aimst.edu.my (S.F.)

4 Institute of Pharmaceutical Sciences, Kurukshetra University, Kurukshetra 136119, Haryana, India; sureshmpharma@rediffmail.com

5 School of Pharmacy, College of Medicine and Health Sciences, University of Gondar, P.O. Box 196, Gondar 6200, Ethiopia; ritz_pharma@yahoo.co.in

6 Department of Pharmacy, College of Medical and Health Sciences, Wollega University, P.O. Box 395, Nekemte, Ethiopia; sureshchennupati@rediffmail.com

7 Arya College of Pharmacy, Dr. A.P.J. Abdul Kalam Technical University, Nawabganj, Bareilly 243407, Uttar Pardesh, India; drhemendragautam@gmail.com

8 Department of Pharmaceutical Chemistry, Ideal Institute of Pharmacy, Wada, Palghar 421303, Maharashtra, India; rssunil29@gmail.com

9 Department of Pharmaceutical Chemistry, Seemanta Institute of Pharmaceutical Sciences, Jharpokharia, Mayurbhanj 757086, Orissa, India; sanjay_karan21@rediffmail.com

10 Department of Pharmaceutical Chemistry, The Oxford College of Pharmacy, Hongasandra, Bangalore 560068, Karnataka, India; jyotishrivastavapharmacy@gmail.com

11 Department of Pharmaceutical Chemistry, U.S. Ostwal Institute of Pharmacy, Mangalwad, Chittorgarh 313603, Rajasthan, India; agarwalalka2014@gmail.com

12 Department of Pharmaceutical Biotechnology, Shrinathji Institute of Pharmacy, Nathdwara 313301, Rajsamand, Rajasthan, India; awadh.k1771@gmail.com

13 Department of Pharmaceutical Chemistry, Shrinathji Institute of Pharmacy, Nathdwara 313301, Rajsamand, Rajasthan, India; jadon_gunjan@yahoo.in

14 Department of Pharmacognosy and Phytochemistry, School of Pharmaceutical Sciences, Delhi Pharmaceutical Sciences and Research University, New Delhi 110017, India; ajaysharmapharma1979@gmail.com

* Correspondence: rajiv.dahiya@sta.uwi.edu (R.D.); sunita.dahiya@upr.edu (S.D.); Tel.: +1-868-493-5655 (R.D.); +1-787-758-2525 (ext. 5413) (S.D.)

+ These authors contributed equally to this work.

Received: 25 May 2020; Accepted: 19 June 2020; Published: 24 June 2020

\begin{abstract}
Peptides are distinctive biomacromolecules that demonstrate potential cytotoxicity and diversified bioactivities against a variety of microorganisms including bacteria, mycobacteria, and fungi via their unique mechanisms of action. Among broad-ranging pharmacologically active peptides, natural marine-originated thiazole-based oligopeptides possess peculiar structural features along with a wide spectrum of exceptional and potent bioproperties. Because of their complex nature and size divergence, thiazole-based peptides (TBPs) bestow a pivotal chemical platform in drug discovery processes to generate competent scaffolds for regulating allosteric binding sites and
\end{abstract}


peptide-peptide interactions. The present study dissertates on the natural reservoirs and exclusive structural components of marine-originated TBPs, with a special focus on their most pertinent pharmacological profiles, which may impart vital resources for the development of novel peptide-based therapeutic agents.

Keywords: azole-based peptide; marine sponge; peptide synthesis; cytotoxicity; cyanobacteria; thiazole; bioactivity

\section{Introduction}

Heterocycles are known to govern a lot of processes of vital significance inside our body, including transmission of nerve impulses, hereditary information, and metabolism. A variety of the naturally occurring congeners, including reserpine, morphine, papaverine, and quinine, are heterocycles in origin, and many of the synthetic bioactives viz. methotrexate and isoniazid contain heterocyclic pharmacophores [1]. Among heterocycles, thiazoles have received special attention as promising scaffolds in the area of medicinal chemistry because this azole has been found alone or incorporated into the diversity of therapeutic active agents such as sulfathiazole, combendazole, niridazole, fanetinol, bleomycin, and ritonavir, which are associated with antibiotic, fungicidal, schistozomicidal, anti-inflammatory, anticancer, and anti-HIV properties [2,3]. Peptides are bioactive compounds of natural origin available in all living organisms and are known for their vital contribution in a wide array of biological activity. Due to their therapeutic abilities, peptides have received growing interest in recent years. In the human body, peptides perform a lot of essential functions including the engagement of peptide hormones like insulin, glucagon-like peptide-1 (GLP-1), and glucagon and in blood glucose regulation and are used to treat novel targets for certain disease conditions, including Alzheimer's disease, diabetes mellitus type 2, and obesity [4-7].

As unique structural features make azole-containing heterocyclic peptides (especially thiazoles) attractive lead compounds for drug development as well as nice tools for advance research, efforts should be made by scientists to develop biologically active thiazole-based peptide derivatives (TBPs). TBPs are obtained from diverse resources, primarily from cyanobacteria, sponges, and tunicates. A thiazole ring can be part of a cyclic structure or connected in a linear chain of peptides either alone or with other heterocycles like oxazole (e.g., thiopeptide antibiotics), imidazole, and indole (in the forms of histidine and tryptophan), thiazoline, oxazoline, etc. Cyclic peptides have an advantage over their linear counterparts as cyclization offers a reduction in conformational freedom, resulting in higher receptor-binding affinities. Understanding the structure-activity relationship (SAR), different modes of action, and routes of synthesis as tools are of vital significance for the study of complex molecules like heterocyclic bioactive peptides, which have a broad spectrum of pharmacological activities associated with them. Further, the sudden increase in the number of peptide drug products is another good reason to study this particular category of compounds on a priority basis. Keeping in view the vital significance of TBPs, the current article focuses on different bioactive marine-derived thiazole-based polypeptides with complex structures and their potent resources, synthetic methodologies, stereochemical aspects, structural activity relationships, diverse modes of action, and bioproperties.

\subsection{Resources}

Various natural sources of TBPs and other heterocyclic rings containing cyclopolypeptides comprise cyanobacteria [8-40], ascidians [41-62], marine sponges [63-70], and sea slugs [71-73]. Moreover, actinomycetes, sea hare, red alga, and higher plants [74-80] were found to be other potential resources of TBPs. 


\subsection{Linear vs. Cyclic Peptides}

In linear peptides with amino acid units between 10 to 20, secondary structures like $\alpha$-helices and $\beta$-strands begin to form, which impose constraints that reduce the free energy of linear peptides. Compared to linear peptides, cyclopeptides are typically considered to have even greater potential as therapeutic agents due to their increased chemical and enzymatic stability, receptor selectivity, and improved pharmacodynamic properties. Although peptide cyclization generally induces structural constraints, the site of cyclization within the sequence can affect the binding affinity of cyclic peptides. Cyclization is a well-known technique to increase the potency and in vivo half-life of peptide molecules by locking their conformation. Hence, both the biological activity and the stability of peptides can be improved by cyclization. The reduction in conformational freedom brought about by cyclization often results in higher receptor-binding affinities. Overall, cyclization of peptides is a vital tool for structure-activity studies and drug development because ring formation limits the flexibility of the peptide chain and allows for the induction or stabilization of active conformations. Moreover, cyclic peptides are less sensitive to enzymatic degradation [81].

The cyclization process often increases the stability of peptides, can prolong their bioeffect, and can create peptides with the ability to penetrate tumors in order to enhance the potency of anticancer drugs [82,83]. Cyclization is envisioned to enhance the selective binding, uptake, potency, and stability of linear precursors. The prolonged activity may even be the result of additional resistance to enzymatic degradation by exoproteases. Cyclic peptides are of considerable interest as potential protein ligands and might be more cell permeable than their linear counterparts due to their reduced conformational flexibility.

Further, cyclic nature of peptides was found to be crucial to their bioactivity in the case of depsipeptides. For example, corticiamide A is a member of a family of structurally related cyclic depsipeptides with tryptophan moiety that include the discodermins, halicylindramides, polydiscamide $\mathrm{A}$, and microspinosamide A. However, corticiamide A is the only member of the family to contain a $p$-Br-Phe at residue 11 and an N-MeAsn. Microspinosamide A and polydiscamide A contained the unusual $\beta$-Me-Ile at residue 6 , whereas the same amino acid is found at residue 5 in corticiamide A. All these peptides were known to be cytotoxic in the low $\mu \mathrm{M}$ range and to inhibit the growth of bacteria and fungi in addition to inhibition of the cytopathic effect of HIV-1 in mosaic human T cell leukemia cells-Syncitial Sensitive (CEM-SS) by microspinosamide A. Interestingly, the cyclic nature of these peptides was important for their bioactivity, with linear versions exhibiting a loss of activity of at least 1 order of magnitude [84,85].

\section{Chemistry}

\subsection{Structural Features of Thiazole (Tzl)-Containing Cyclooligopeptides}

Aestuaramides, banyascyclamides, ulongamides (1-3), guineamides $(4,5)$, microcyclamides MZ602 and MZ568, trichamide, tawicyclamides (6,7), obyanamide (8), cyclodidemnamide and cyclodidemnamide B, lyngbyabellins, oriamide (9), scleritodermin A (10), haligramide A (11), waiakeamide (12), haligramide B (13), mollamide C (15), jamaicensamide A (16), myotamides, didmolamides, dolastatin 3, homodolastatin 3, sanguinamides, cyclotheonellazoles, aeruginazole A, aeruginazole DA1497, aeruginazole DA1304, and aeruginazole DA1274 are examples of heterocyclic thiazole-based polypeptides having diverse unusual structural features from marine organisms.

Cyanobactin cyclopolypeptide aestuaramide A contained valylthiazole (Val-Tzl) and prolylthiazole (Pro-Tzl) residues in addition to proline, valine, and methionine units and a reverse $O$-Tyr isoprene moiety (Ptyr). Aestuaramide B was found to be an unprenylated analogue of aestuaramide A, whereas aestuaramide $\mathrm{C}$ was found to be a forward C-prenylated derivative. Aestuaramide D-F and aestuaramide $\mathrm{J}-\mathrm{L}$ were found to be the sulfoxide derivatives of aestuaramides $\mathrm{A}-\mathrm{C}$ and aestuaramides G-I, respectively. Similarily, aestuaramides G-L were reverse O-prenylated, unprenylated, or forward C-prenylated congeners, with or without Met oxidation, but contained alanylthiazole (Ala-Tzl) instead 
of a Val-Tzl unit of aestuaramides A-F. Cyclic peptides such as aestuaramides may be exceptionally widespread metabolites in natural ecosystems [10].

Banyascyclamides B and C are modified cyclopolypeptides, closely related in structure, and composed of two thiazole-alanine units. The cyclohexapeptide banyascyclamide $\mathrm{C}$ exhibited close structural similarity with banyascyclamide A but differed in having L-phenylalanyl-L-threonine moiety instead of L-Phe-mOzl residue of banyascyclamide A. Similarily, banyascyclamide B differed from banyascyclamide C in having L-leucyl-L-threonine moiety instead of L-phenylalanyl-L-threonine residue [11].

The cyanobacterium-derived ulongamide A (1) and other ulongamides B-F are alanine-derived thiazole carboxylic acid (L-Ala-Tzl-ca) containing cyclodepsipeptides which possessed a novel $\beta$-amino acid residue, 3-amino-2-methylhexanoic acid (Amha). Further, there was the presence of 2-hydroxyisovaleric acid (Hiva) in ulongamide D (2) and 2-hydroxy-3-methylpentanoic acid (Hmpa) in ulongamide $\mathrm{E}$ and ulongamide $\mathrm{F}$ (3), which had replaced the L-lactic acid moiety present in ulongamides $\mathrm{A}-\mathrm{C}$. Ulongamides $\mathrm{A}-\mathrm{E}$ displayed weak in vitro cytotoxicity against ubiquitous KERATIN-forming tumor cell subline (KB) and LoVo cells [13] (Figure 1).

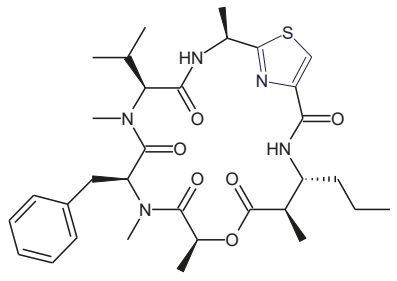

1

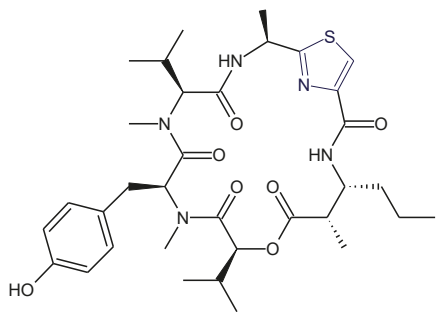

2

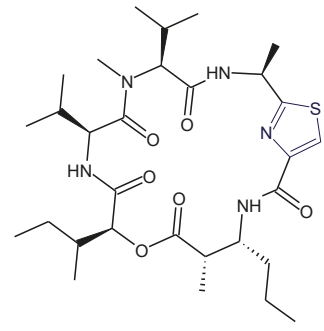

3

Figure 1. Structures of ulongamide A (1), ulongamide D (2), and ulongamide F (3) with alanylthiazole (Ala-Tzl) and 3-amino-2-methylhexanoic acid (Amha) moieties.

The cyanobacterium-derived guineamide A (4) contained the common L-alanine-disubstitutedthiazole unit, unique $\beta$-amino acid 2-methyl-3-aminopentanoic acid (Mapa), lactic acid (L-Lac), $N$-methylated amino acids viz. $N$-methylphenylalanine (L-N-MePhe), and $N$-methylvaline (L- $N$-MeVal), but guineamide B (5) deviated from guineamide A (4) in having 2-hydroxyisovaleric acid (L-Hiv) and 2-methyl-3-aminobutanoic acid (Maba) units instead of L-Lac and Mapa units. The absolute stereochemistry of the 2-methyl-3-aminopentanoic acid (Mapa) unit in guineamide A (4) was found to be $2 S, 3 R$. From a biosynthetic perspective, the guineamides were found to be interesting molecules because of the presence of unusual $\alpha$-amino and $\beta$-hydroxy acid residues. Further, guineamide B (5) exhibited moderate cytotoxic activity against a mouse neuroblastoma cell line [14] (Figure 2).

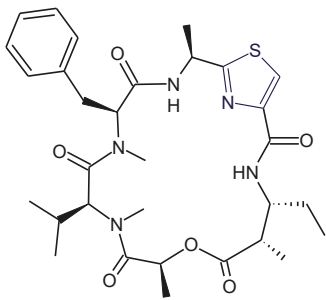

4

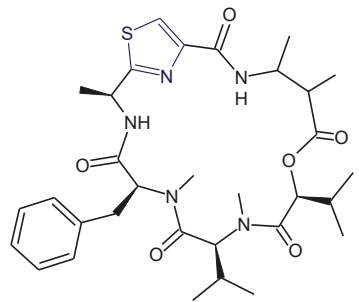

5

Figure 2. Structures of guineamide A (4) and guineamide B (5) with Ala-Tzl and L-N-Methylated amino acid units. 
Microcyclamides MZ602 and MZ568 contained isoleucylthiazole moiety in common but differed in having phenylalanine and glycine amino acids in the former and valine and alanine in the latter. Trichamide possessed serylthiazole and leucylthiazole moieties in addition to histidine amino acid [18].

The cyanobacterium-derived lyngbyabellin A is a significantly cytotoxic dichlorinated peptolide with unusual structural features, including a dichlorinated $\alpha$-hydroxy acid and two functionalized thiazole carboxylic acid units. This depsipeptide was found to be a potent disrupter of the cellular microfilament network [27]. Lyngbyabellin B is related cyclic depsipeptide in which one thiazole unit was replaced by a thiazoline ring, with the placement of the ring between the glycine residue and the $\alpha, \beta$-dihydroxyisovaleric acid rather than adjacent to the valine-derived unit, and the isoleucine-derived unit in lyngbyabellin A was replaced by a valine-derived moiety in lyngbyabellin B. Lyngbyabellin B displayed potent toxicity toward brine shrimp and the fungus Candida albicans and was found to be slightly less cytotoxic in vitro than lyngbyabellin A against KB and LoVo cells, respectively [86]. The structures of lyngbyabellin $\mathrm{E}$ and $\mathrm{H}$ showed the presence of two 2,4-disubstituted thiazole rings and differed7 in having the $\alpha, \beta$-dihydroxyisovaleric acid (dhiv) unit in lyngbyabellin $\mathrm{E}$ replaced by the 2-hydroxyisovaleric acid (hiva) unit in lyngbyabellin $\mathrm{H}$. Intriguingly, lyngbyabellin $\mathrm{E}$ and $\mathrm{H}$ appeared to be more active against the H460 human lung tumor cell lines. From the bioactivity results, it appeared that lung tumor cell toxicity is enhanced in the cyclic representatives with an elaborated side chain [28].

In addition to two thiazole rings and a chlorinated 2-methyloctanoate residue, lyngbyabellin $\mathrm{N}$ contained an unusual dimethylated valine terminus and a leucine statine residue. The planar structure of lyngbyabellin $\mathrm{N}$ was closely related to that of lyngbyabellin $\mathrm{H}$ except for the replacement of the polyketide portion with an N,N-dimethylvaline (DiMeVal) residue [29]. The cytotoxic lyngbyabellin J contained the gem-dichloro moiety as part of a 7,7-dichloro-3-acyloxy-2-methyloctanoate residue in addition to the $\alpha, \beta$-dihydroxy- $\beta$-methylpentanoic acid (Dhmpa, $C_{19-24}$ ) unit and two disubstituted thiazole rings [30].

Tawicyclamides A and B $(6,7)$ represent a novel category of cyclooligopeptides, bearing alternative sequences of two thiazoles and one thiazoline amino acid but lacking the oxazoline ring, which is characteristic of ascidian-derived heptapeptides lissoclinamides and the octapeptides patellamides/ulithiacyclamides. Moreover, the presence of a cis-valine-proline amide bond facilitates an unusual three-dimensional conformation to ascidian-derived tawicyclamides A and B $(6,7)$. Tawicyclamide B (7) differs from tawicyclamide A (6) in having a leucine moiety in place of the phenylalanine residue of tawicyclamide A [41] (Figure 3).

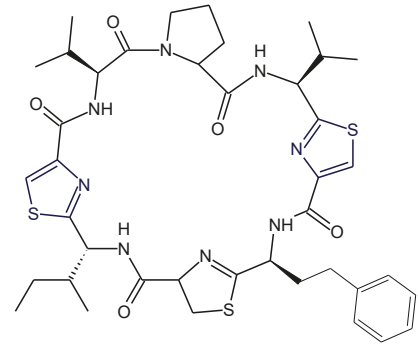

6

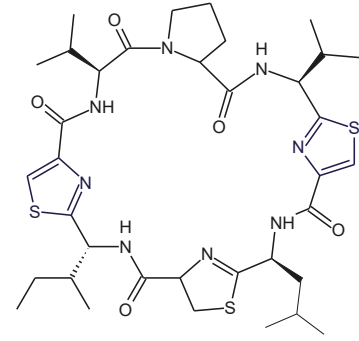

7

Figure 3. Structures of tawicyclamide A (6) and tawicyclamide B (7) with valylthiazole (Val-Tzl) and L-isoleucyl-thiazole (Ile-Tzl) moieties.

In the structure of depsipeptide-obyanamide (8), the alanylthiazole (Ala-Tzl) unit and 3-aminopentanoic acid (Apa) were present [12,42] whereas the sponge-derived cytotoxic cyclic peptide, oriamide (9), was found to contain a new 4-propenoyl-2-tyrosylthiazole amino acid (PTT) moiety. Further, a novel conjugated thiazole moiety viz. 2-(1-amino-2- $p$-hydroxyphenylethane)-4- 
(4-carboxy-2,4-di-methyl-2Z,4E-propadiene)-thiazole (ACT) was found to be part of the structure of tubulin inhibitory sponge-derived cyclopolypeptide scleritodermin A (10), along with $\mathrm{O}$-methyl- $\mathrm{N}$-sulfoserine and keto-allo-isoleucine units [64] (Figure 4).

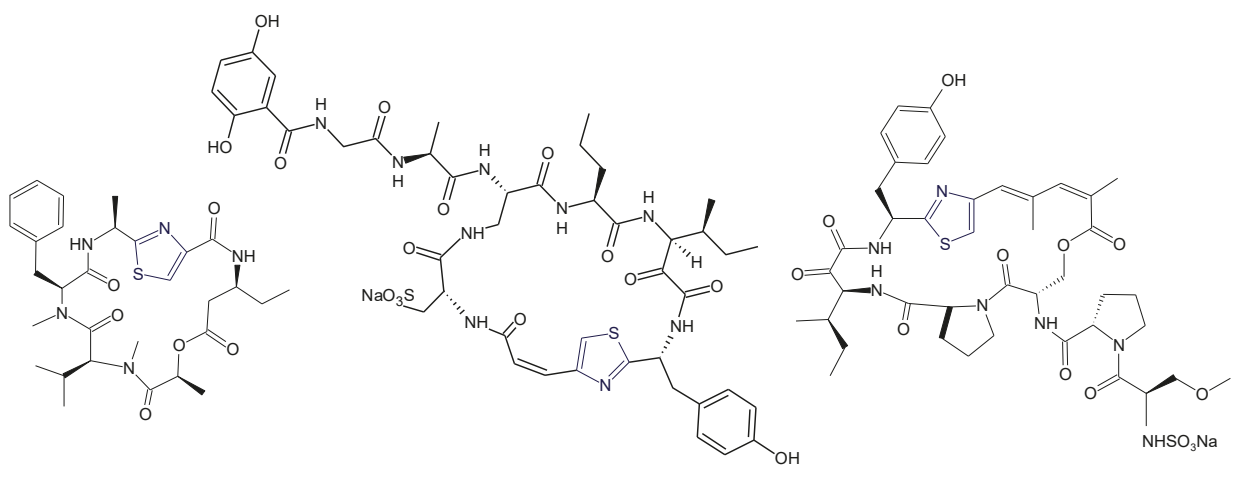

8

9

10

Figure 4. Structures of obyanamide (8) with Ala-Tzl moiety, oriamide (9) with 4-propenoyl-2-tyrosylthiazole amino acid (PTT) moiety, and scleritodermin A (10) with 2-(1-amino-2-p-hydroxyphenylethane)-4- (4-carboxy-2,4-di-methyl-2Z,4E-propadiene)-thiazole (ACT) moiety.

In the structure of the bisthiazole-containing macrocyclic peptide, cyclodidemnamide B, two thiazole moieties viz. prolylthiazole (L-Pro-Tzl) and leucylthiazole (D-Leu-Tzl) were found to be present. The ascidian-derived cyclodidemnamide was found to be similar to reverse prenyl substituted cytotoxic cycloheptapeptide mollamide only in possessing the same dihyrothiazole-proline dipeptide unit $\left(\mathrm{C}_{20}-\mathrm{C}_{27}\right)$, but it also contained leucylthiazole and phenylalanyl-methyl oxazoline moieties [43,62].

The sponge-derived cytotoxic hexapeptides haligramide A and B $(\mathbf{1 1}, \mathbf{1 3})$ were found to contain the phenylalanylthiazole (Phe-Tzl) moiety in addition to three proline units. Haligramide A (11) was the bismethionine analogue of waiakeamide (12), bearing Phe-Tzl moiety. Haligramide B (13) contained both methionine and methionine sulfoxide residues in comparison to haligramide A (11) which contained only methionine residues and waiakeamide (12), another sponge-derived cyclohexapeptide that contained methionine sulfoxide residues only [63,66] (Figure 5).

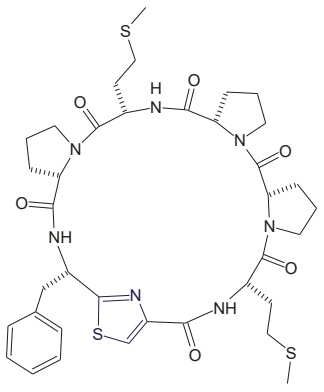

11

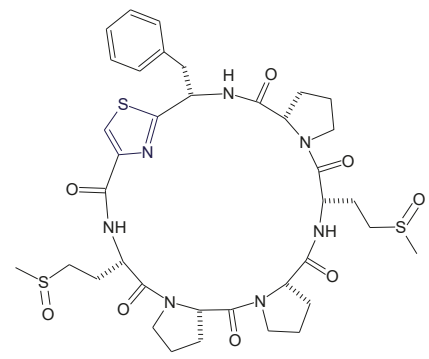

12

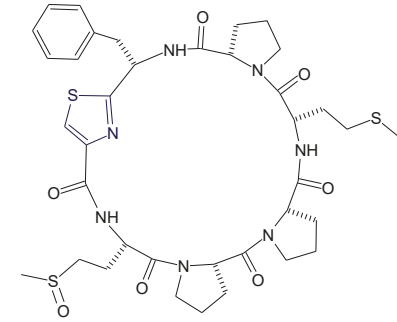

13

Figure 5. Structures of haligramide A (11), waiakeamide (12), and haligramide B (13) with phenylalanylthiazole (Phe-Tzl) moieties. 
A unique amino acid, 2-bromo-5-hydroxytryptophan (BhTrp), and an unusual ureido linkage were found to be present in the composition of sponge-derived peptide konbamide with calmodulin antagonistic activity [87]. Further, the cytotoxic depsipeptide polydiscamide A contained a novel amino acid 3-methylisoleucine in addition to heterocyclic tryptophan moiety $[65,88]$.

The notaspidean mollusk-derived cytotoxic cyclic hexapeptide keenamide A (14) contained a leuylthiazoline (Leu-Tzn) unit together with serylisoprene residue in its structure and differed from mollamide C (15), a tunicate-derived cyclohexapeptide, in having thiazoline moiety instead of thiazole [72]. Trunkamide A contained a thiazoline heterocycle and two residues of Ser and Thr with the hydroxy function modified as reverse prenyl (rPr). The structure of jamaicensamide A (16), a sponge-derived peptide having $\beta$-amino- $\alpha$-keto and thiazole-homologated $\eta$-amino acid residues, was found to contain 2-aminobutanoic acid (Aba), 5-hydroxytryptophan (HTrp), and a terminal 2-hydroxy-3-methylpentanamide (Hmp) unit [44,89] (Figure 6).

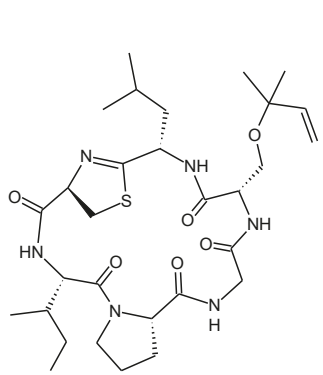

14

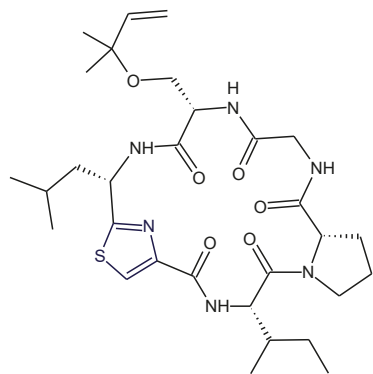

15

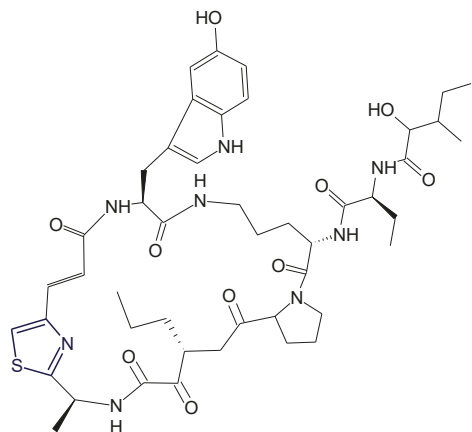

16

Figure 6. Structures of keenamide A (14) with leuylthiazoline (Leu-Tzn) moiety, mollamide C (15) with Leu-Tzl moiety, and jamaicensamide A (16) with Ala-Tzl and 2-hydroxy-3-methylpentanamide (Hmp) residues.

Myotamides A and B are ascidian-derived cycloheptapeptides that contained three unusual amino acids containing heteroatoms including one thiazole (Tzl) and two thiazoline (Tzn) rings in addition to valine, proline, isoleucine, and methionine. Mayotamide A embodied the same Val-Pro-Tzn sequence as was found in ascidian-derived cyclic heptapeptide cyclodidenmamide and also contained an additional thiazoline (Tzn) ring. Myotamide A differed from myotamide B in having isoleucine moiety, which was replaced by valine moiety in the latter. Both cyclopolypeptides exhibited cytotoxicity against tumor cell lines [45].

Didmolamide B is a thiazole-containing ascidian-derived cyclopolypeptide that contained two $\mathrm{L}$-alanylthiazole residues, and L-phenylalanine and L-threonine moieties. The threonine residue of didmolamide B was modified to a methyloxazoline ( $\mathrm{mOzn}$ ) heterocycle in the case of didmolamide A. Didmolamide B was found to exhibit mild cytotoxicity against several cultured tumor cell lines [48].

Dolastatin 3 is a cyanobacterium- as well as sea hare-derived cyclopolypeptide that contained two L-glutaminyl-thiazole (L-Gln-Tzl) and glycyl-thiazole (Gly-Tzl) units in addition to L-valine, L-leucine, and L-proline residues. The cyanobacterium-derived homodolastatin 3 differed from dolastatin 3 by the addition of a methylene group, i.e., an L-isoleucine residue in place of the L-valine residue of dolastatin 3. The cyclopentapeptide dolastatin 3 was found to exhibit HIV-1 integrase inhibitory activity as well as P388 lymphocytic leukemia (PS) cell growth inhibitory activity. Kororamide is another cyanobacterium-derived polypeptide having two L-tyrosinyl-thiazole (L-Tyr-Tzl) and leucyl-thiazoline (Leu-Tzn) units in addition to L-leucine, L-isoleucine, L-serine, L-proline, and L-asparagine residues $[9,90]$. 
The sponge-derived cyclotheonellazoles A-C are unusual cyclopolypeptides containing nonproteinogenic acids, the most unique being 4-propenoyl-2-tyrosylthiazole (PTT), 3-amino-4-methyl-2-oxohexanoic acid (Amoha), and diaminopropionic acid (Dpr), along with two or three proteinogenic amino acids like glycine and alanine. Cyclotheonellazoles $\mathrm{B}$ and $\mathrm{C}$ shared the same basic structure with cyclotheonellazole A, in which leucine (in cyclotheonellazole B) and homoalanine (in cyclotheonellazole C) replaced the 2-aminopentanoic acid residue of cyclotheonellazole A. Cyclotheonellazoles were found to be nanomolar inhibitors of chymotrypsin and sub-nanomolar inhibitors of elastase [68].

The nudibranch-derived sanguinamide $\mathrm{A}$ is a modified heptapeptide containing a 2-substituted thiazole-4-carboxamide moiety. Structural analysis of this peptide indicated the presence of two residues, L-proline and L-isoleucine, present in alternative continuous sequences in addition to amino acid moieties phenylalanine and alanine with an L-configuration. In this cycloheptapeptide, azole-modified amino acid was found to be L-isoleucyl-thiazole (L-Ile-Tzl). In comparison to sanguinamide A, the cyclic octapeptide sanguinamide B was found to contain additional heteroaromatic oxazole and thiazole rings [73].

The cyanobacterium-derived polythiazole peptide aeruginazole DA1497 contained leuylthiazole (Leu-Tzl), alanylthiazole (Ala-Tzl), phenylalanylthiazole (Phe-Tzl), and valylthiazole (Val-Tzl) residues and exhibited bioproperties against Gram-positive bacterium Staphylococcus aureus. However, in related cyclopolypeptides, aeruginazole DA1304 and aeruginazole DA1274 moieties like asparaginylthiazole (Asn-Tzl), Leu-Tzl and isoleucylthiazole (Ile-Tzl) were found to be present. L-Asn-Tzl moiety was also observed in the polythiazole containing cyanobacterium-derived polypeptide aeruginazole $\mathrm{A}$ in addition to D-Leu-Tzl and L-Val-Tzl residues. This cyclododecapeptide was found to potently inhibit the Gram-positive bacterium Bacillus subtilis [8,91].

\subsection{Structural Features of Tzl-Containing Linear Peptides}

In addition to cyclopolypeptides, heterocyclic thiazole ring-based linear peptides are also obtained from marine organisms. Micromide (17), apramides (18,19), dolastatin 10 (20), symplostatin 1 (21), dolastatin 18 (22), lyngbyapeptins A and C (23,24), and lyngbyabellin F (25) and I (26) are the best examples of linear peptides containing thiazole rings.

Micromide (17) is a highly $N$-methylated linear peptide containing structural features common to many cyanobacterial metabolites, including a D-amino acid, a modified cysteine unit in the form of a thiazole ring and $\mathrm{N}$-methylated amino acids. The structrural components of this peptide included moieties like 3-methoxyhexanoic acid, $\mathrm{N}$-Me-Gly-thiazole, and other $\mathrm{N}$-methylated amino acids viz. $\mathrm{N}$-Me-Phe, N-Me-Ile, N-Me-Val, etc. Micromide (17) was found to exhibit cytotoxicity against KB cells [92]. On the other hand, the cyanobacterium-derived apramides A-G are linear lipopeptides containing a thiazole-containing modified amino acid unit. Structural analysis of apramide A (18) suggested the presence of a 2-methyl-7-octynoic acid moiety (Moya) and six amino acid residues ( $\mathrm{N}$-Me-Ala, Pro, $\mathrm{N}, \mathrm{O}$-diMe-Tyr, and 3 units of $\mathrm{N}$-Me-Val) and a C-terminally modified amino acid unit (N-Me-Gly-thz). Structures of apramide B and apramide C (19) differed from apramide A (18) in having the presence of a 7-octynoic acid unit (Oya) and 2-methyl-7-octenoic acid moiety (Moea) in lieu of the Moya moiety of apramide A (18). Apramides D-F differed from apramide A (18), B, and C (19), only by bearing a Pro-Tzl unit instead of the N-Me-Gly-Tzl residue, which had caused a drastic impact on the conformational behavior. The lipopeptide apramide A (18) was found to enhance elastase activity [93] (Figure 7). 
<smiles>CCCC(CC(=O)N[C@@H](Cc1ccccc1)C(=O)N(C)[C@H](C(=O)N[C@H](C(=O)N(C)[C@H](C(=O)N(C)[C@H](Cc1ccccc1)C(=O)N(C)Cc1nccs1)C(C)C)C(C)C)C(C)CC)OC</smiles>

17<smiles>C#CCCCCCC(C)C(=O)N(C)C[C@H](C)C(=O)N(C)[C@H](C(=O)N(C)Cc1nccs1)C(=O)N1CCC[C@H]1C(=O)N(C)[C@@H](C(=O)N(C)[C@H](C(=O)N(C)[C@@H](Cc1ccc(OC)cc1)C(C)C)C(C)C)C(C)C</smiles>

18<smiles>C=CCCCCCC(C)C(=O)N(C)[C@@H](C)C(=O)N(C)[C@H](C(=O)N(C)Cc1nccs1)C(=O)N1CCC[C@H]1C(=O)N(C)[C@@H](C(=O)N(C)C(C(=O)N(C)[C@@H](Cc1ccc(OC)cc1)C(C)C)C(C)C)C(C)C</smiles>

19

Figure 7. Structures of micromide (17), apramide A (18), and apramide C (19) with terminal $\mathrm{N}$-Me-Gly-Tzl residues.

The dolastatins are sea hare- and marine cyanobacterium-derived compounds that exhibit cytotoxic properties. Dolastatin 10 (20) is a linear thiazole-containing heterocyclic peptide bearing $\mathrm{N}, \mathrm{N}$-dimethylvaline, $(3 R, 4 S, 5 S)$-dolaisoleucine, $(2 R, 3 R, 4 S)$-dolaproine, and (S)-dolaphenine [94]. Like dolastatin 10 (20), cyanobacterium-derived symplostatin 1 (21) is a potent microtubule inhibitor. Symplostatin 1 (21) differed from dolastatin 10 (20) by the replacement of the iso-propyl group by a sec-butyl group on the first $N$-dimethylated amino acid. Symplostatin 1 (21) is a very potent cytotoxin but not as potent as dolastatin 10 (20), whereas synthetic analogues lacking the $\mathrm{N}, \mathrm{N}$-dimethylamino acid residue were reported to be markedly less cytotoxic. The structure of symplostatin 1 (21) differed from dolastatin 10 (20) by only one additional $\mathrm{CH}_{2}$ unit in the $\mathrm{N}$-terminal residue. The absolute configuration of the stereocenter at C-26 in symplostatin 1 (21) was found to be $26 S$. The biological evaluation of symplostatin 1 (21) revealed that it is highly active against certain tumors and comparable in its activity with isodolastatin $\mathrm{H}$. Both dolastain 10 (20) as well as its methyl analog, symplostatin 1 (21) were found to be potent microtubule depolymerizers [95,96].

Dolastatin 18 (22) is another cancer cell growth inhibitory linear peptide bearing thiazole moiety from the sea hare, the structure of which is derived from two $\alpha$-amino acids (Leu and MePhe), a dolaphenine (Doe) unit, and the new carboxylic acid 2,2-dimethyl-3-oxohexanoic acid (dolahexanoic acid, Dhex). Dolastatin 18 (22) was found to significantly inhibit growth of human cancer cell lines [97] (Figure 8). 


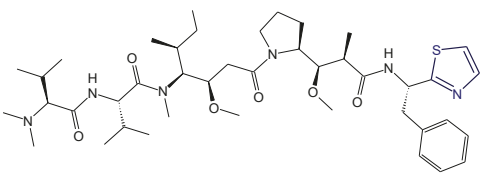

20

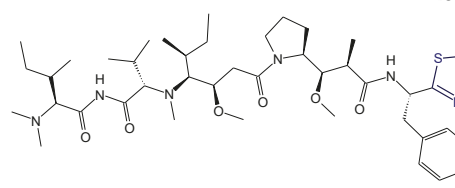

21

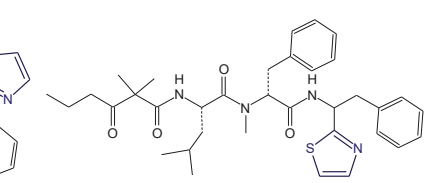

22

Figure 8. Structures of dolastatin 10 (20), symplostatin 1 (21), and dolastatin 18 (22) with terminal Phe-Tzl residues.

Lyngbyapeptins are thiazole-containing lipopeptides with a rare 3-methoxy-2-butenoyl moiety with a high level of $\mathrm{N}$-methylation. The cyanobacterium-derived lyngbyapeptin A (23) is a linear modified peptide with a 2-substituted thiazole ring. In comparison to lyngbyapeptin A (23), lyngbyapeptin B and C possess the same/similar characteristic C- and N-terminal modification and differed by containing other amino acid units in between. Structural analysis of lyngbyapeptin B indicated the presence of two $\mathrm{N}, \mathrm{O}$-dimethyltyrosine residues, an $\mathrm{N}$-methylvaline unit, a thiazole-containing modified alanine (Ala-thz) unit, and a 3-methoxy-2-butenoic acid (Mba) moiety with the absolute stereochemistry $S$ for the methylated amino acids. The structure of lyngbyapeptin C (24) differed from that of lyngbyapeptin B in having the presence of an $N$-terminal unit and 3-methoxy-2-pentenoic acid (Mpa) residue. The structure of lyngbyapeptin D (27) differed from that of lyngbyapeptin A (23) in having $\mathrm{N}$-Me-Val residue instead of $\mathrm{N}$-Me-Ile in addition to $\mathrm{N}$-Me-Leu, a thiazole-containing modified proline (Pro-thz) unit and $\mathrm{N}, \mathrm{O}$-dimethyltyrosine ( $\mathrm{N}, \mathrm{O}$-diMe-Tyr) $[98,99]$. Lyngbyabellin F (25) and I (26) are linear dichlorinated lipopeptides that showed the presence of two 2,4-disubstituted thiazole rings. Lyngbyabellin I (26) and F (25) were found to be cytotoxic to human lung tumor and neuro-2a mouse neuroblastoma cells [100] (Figure 9).

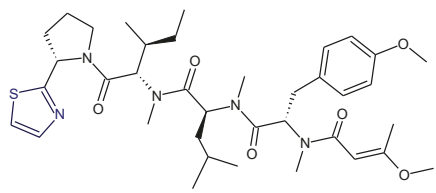

23

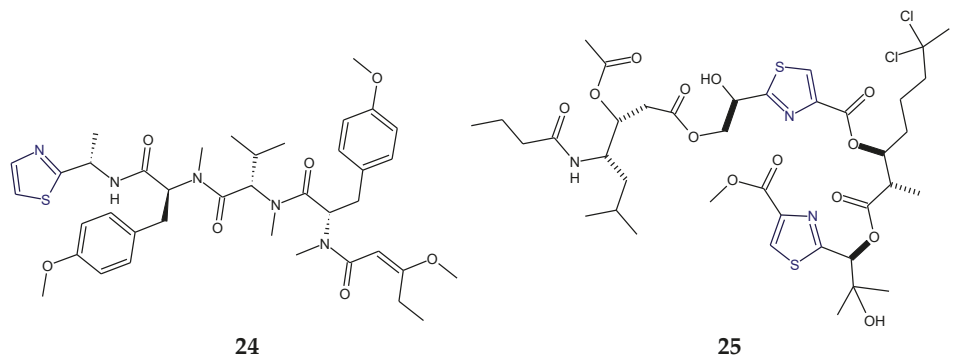

24

25

Figure 9. Cont. 


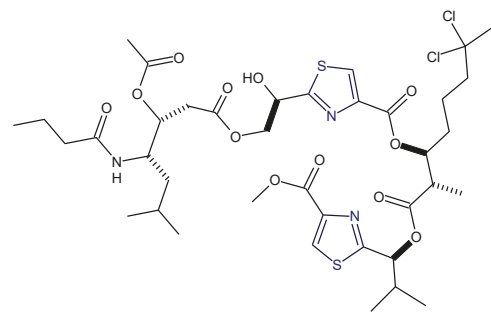

26

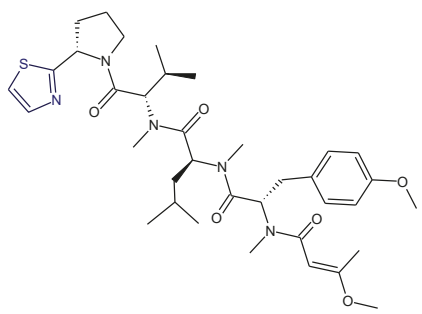

27

Figure 9. Structures of lyngbyapeptin A (23) with Pro-Tzl moiety, lyngbyapeptin C (24) withAla-Tzl moiety, lyngbyabellin F (25) with $\alpha, \beta$-dihydroxyisovaleric acid (DHIV)-Tzl residue, lyngbyabellin I (26) with Val-Tzl moiety, and lyngbyapeptin D (27) with Pro-Tzl moiety.

\subsection{Structural Features of Thiazole (Tzl)-and Oxazole (Ozl)-Containing Cyclopeptides}

In addition to cyclic peptides with thiazole/thiazoline rings, mixed heterocyclic ring-based cyclopeptides are also derived from marine resources. Comoramide A, didmolamides A-C (28-30), vemturamides $(31,32)$, dolastatins $\mathrm{E}$ and I $(34,35)$, microcyclamide (36), bistratamides (37-41), raocyclamides $(\mathbf{4 2 , 4 3 )}$, tenuecyclamides, patellamides, and lissoclinamides are bioactive cyclooligopeptides containing thiazole and oxazole rings.

Comoramides are cyanobactins that contained prenylated amino acids. The ascidian-derived cyclopeptide comoramide A was isolated with threonine heterocyclized in position 5 and prenylated in position 3 and was found to contain six amino acids in its structure, including two amino acids that existed as a 5-methyloxazoline ( $\mathrm{mOzn}$ ) heterocycle and as a thiazoline ring (Tzn). The additional amino acid moieties present were L-alanine, L-phenylalanine, and L-isoleucine. Like patellin, trunkamide A, mollamide, and hexamollamide, comoramide $\mathrm{A}$ was found to be a unique type of peptide that contained threonine residue for which the side chain is modified as dimethylallyl ether. This cyclohexapeptide exhibited structural similarilty with another ascidian-derived cycloheptapeptide mollamide in two amino acids viz. Ile-Tzn and Phe-Thr. Comoramide A was found to be cytotoxic against the A549, HT29, and MEL-28 tumor cell lines [45].

Didmolamides A and B $(\mathbf{2 8 , 2 9 )}$ are ascidian-derived cyclohexapeptides that contained two L-alanylthiazole residues and one L-phenylalanine moiety in common but didmolamide A (28) contained 5-methyloxazoline ( $\mathrm{mOzn}$ ) heterocycle in addition, which is replaced by L-threonine moiety in didmolamide B (29). Morover, didmolamide C (30) differs from didmolamides A and B $(28,29)$ in the oxidation state of the heterocyclic rings, having two thiazoline rings (instead of thiazoles) in didmolamide C (30). Additionally, didmolamide C (30) was found to contain a methyloxazole ring instead of a methyloxazoline ring of didmolamide A (28). Didmolamide A (28) displayed mild cytotoxicity against the A549, HT29, and MEL28 tumor cell lines [48,101] (Figure 10).

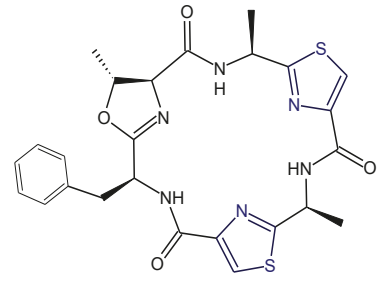

28

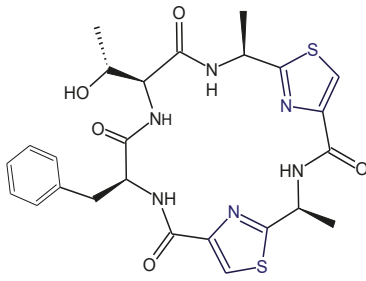

29

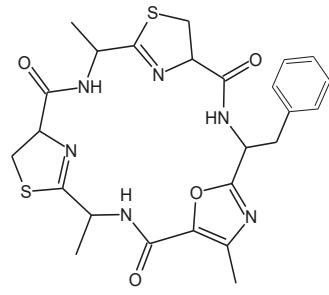

30

Figure 10. Structures of didmolamide A (28) with Ala-Tzl moieties, didmolamide B (29) with Ala-Tzl moieties, and didmolamide C (30) with Ala-Tzn moieties. 
Venturamides $(31,32)$ are cyanobacterium-derived thiazole- and methyloxazole-containing cyclohexapeptides that exhibited antimalarial and cytotoxic activities. Structural analysis of venturamide $\mathrm{B}(32)$ indicated the presence of $\mathrm{D}$-alanine, $\mathrm{D}$-valine, and $\mathrm{D}$-allo-threonine in addition to three heteroaromatic moieties. The polypeptide venturamide B (32) was identified as cyclo-D-allo-Thr-Tzl-D-Val-Tzl-D-Ala-mOzl. The cyclic hexapeptide venturamide B (32) differed from venturamide $\mathrm{A}$ (31) in having a D-threonine unit in place of the D-alanine adjacent to the thiazole ring. There was a close similarity between the structures of venturamide A (31) and blue-green alga-derived cyclopeptide dendroamide A (33): however, D-valine and D-alanine are exchanged with each other, adjacent to two thizaole heterocycles at C-12 and C-20. Venturamides $(\mathbf{3 1}, \mathbf{3 2})$ showed strong in vitro activity against Plasmodium falciparum, with only mild cytotoxicity to mammalian Vero cells. Also, mild activity against Trypanasoma cruzi, Leishmania donovani, and MCF-7 cancer cells was also reported for venturamides [34] (Figure 11).

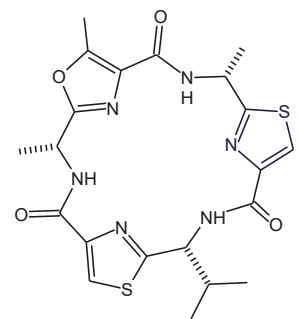

31

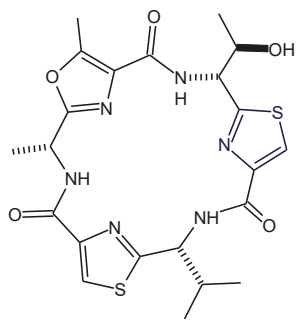

32

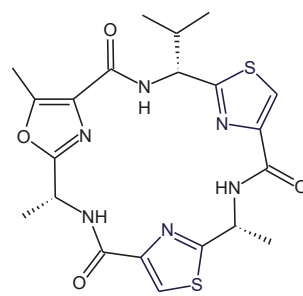

33

Figure 11. Structures of venturamide A (31) with Ala-Tzl and Val-Tzl residues, venturamide B (32) with Thr-Tzl and Val-Tzl residues, and dendroamide A (33) with Val-Tzl and Ala-Tzl residues.

The sea hare-derived cyclopolypeptides dolastatins E and I $(34,35)$ were found to contain three kinds of five-membered heterocycles viz. oxazole/methyloxazole $(\mathrm{Ozl} / \mathrm{mOzl})$, thiazole (Tzl), and thiazoline/oxazoline (Tzn/Ozn), in addition to one residue each of $\mathrm{D}$-alanine and $\mathrm{L}$-alanine and one residue of D-isoleucine in dolastatin $\mathrm{E}$ (34) while one residue each of L-alanine, $\mathrm{L}$-valine, and L-isoleucine in the case of dolastatin I (35). Although both of these cyclic hexapeptides displayed cytotoxicity against $\mathrm{HeLa} \mathrm{S}_{3}$ cells, in comparison, dolastatin I (35) was found to be more cytotoxic than dolastatin $\mathrm{E}[75,76]$. On the other hand, in addition to two thiazole (Tzl) and one methyloxazole (mOzl) rings, the cyanobacterium-derived cyclopeptide microcyclamide (36) contained two usual amino acids, L-isoleucine and L-alanine, and one $\mathrm{N}$-methylhistidine residue. Overall, the hexapeptidic structure was composed of three units viz. thiazole-methylhistidinyl, thiazole-isoleucinyl, and methyloxazole-alanyl units. This cyclic hexapeptide displayed a moderate cytotoxic activity against P388 murine leukemia cells [35] (Figure 12).

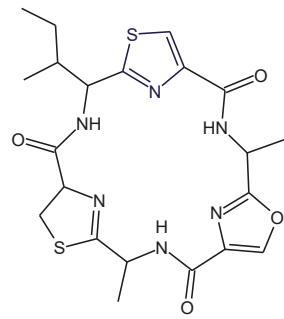

34

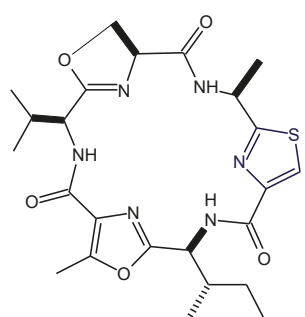

35

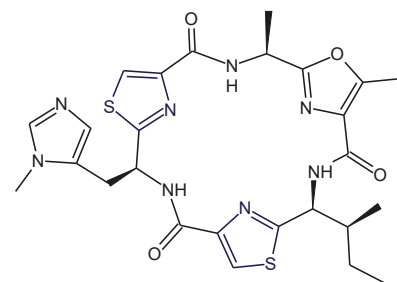

36

Figure 12. Structures of dolastatin E (34) with Ile-Tzl moiety, dolastatin I (35) with Ala-Tzl moiety, and microcyclamide (36) with Ile-Tzl and N-Me-His-Tzl residues. 
The ascidian-derived bistratamide A and B contained heteroaromatic rings viz. methyloxazoline (mOzn) and thiazoline (Tzn) rings in common in addition to one residue each of alanine, phenylalanine, and L-valine. However, bistratamide A differed from bistratamide B only in the conversion of one thiazoline ring to a thiazole, i.e., these hexapeptides differed only by the the presence or absence of one double bond. Both these cyclohexapeptides displayed activity toward human cell lines viz. MRC5CV1 fibroblasts and T24 bladder carcinoma cells. Bistratamides C and D $(37,38)$ possessed one thiazole ring in common in addition to two L-valine residues. However, bistratamide C (37) differed from bistratamide D (38) in having an L-alanine moiety instead of additional L-valine. Moreover, the other two heteroaromatic rings in bistratamide D (38) were methyloxazoline and oxazole, whereas in bistratamide $C$ (37), oxazole and thiazole rings were present. Bistratamides $\mathrm{E}$ and $\mathrm{F}$ were found to contain three residues of $\mathrm{L}$-valine in addition to thiazole and methyloxazoline rings. Bistratamide $\mathrm{F}$ differed from bistratamide $\mathrm{E}$ in having an additional oxazoline ring instead of a second thiazole ring in bistratamide E. Similarily, bistratamides $\mathrm{G}$ and $\mathrm{H}(39,40)$ were found to contain three residues of $\mathrm{L}$-valine in addition to thiazole and methyloxazole rings. Bistratamide $\mathrm{G}$ (39) differed from bistratamide $\mathrm{H}(40)$ in having an additional oxazole ring instead of a second thiazole ring in bistratamide $\mathrm{H}(40)$. Further, bistratamide I (41) contained three residues of L-valine in addition to one thiazole and one oxazole ring. The ascidian-derived bistratamides $\mathrm{M}$ and $\mathrm{N}(46,47)$ are oxazole-thiazole-containing cyclic hexapeptides that displayed moderate cytotoxicity against four human tumor cell lines including NSLC A-549 human lung carcinoma cells, MDA-MB-231 human breast adenocarcinoma cells, HT-29 human colorectal carcinoma cells, and PSN1 human pancreatic carcinoma cells. Moreover, bistratamides G-I (39-41) and J showed weak to moderate activity against the HCT-116 human colon tumor cell line [50,59-61] (Figure 13).

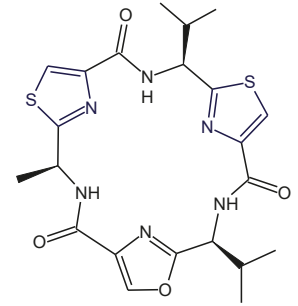

37

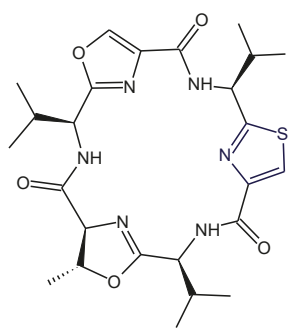

38

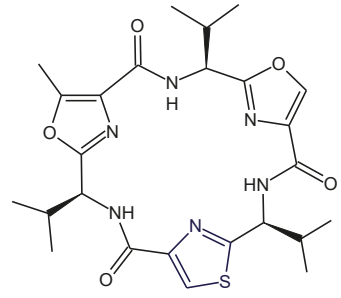

39

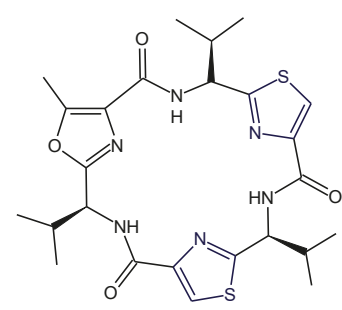

40

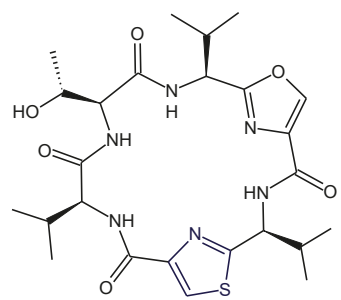

41

Figure 13. Structures of bistratamide C (37) with Val-Tzl and Ala-Tzl residues, bistratamide D (38) with Val-Tzl moiety, bistratamide G (39) with Val-Tzl moiety, bistratamide H (40) with two Val-Tzl residues, and bistratamide I (41) with Val-Tzl moiety.

Raocyclamides $(42,43)$ are cyclooligopeptides in which the ring system contains amide links only, and they contain three heteroaromatic rings symmetrically arranged in a peptide chain with different connected aliphatic amino acids providing structural diversity. Raocyclamides A and B $(42,43)$ are cyanobacterium-derived oxazole- and thiazole-containing cyclic hexapeptides with cytotoxic 
properties. Raocyclamide A (42) contained three standard amino acid residues viz. D-isoleucine, L-alanine, and D-phenylalanine and three modified amino acids viz. thiazole, oxazole, and oxazoline. In comparison, raocyclamide B (43) contained four standard amino acid residues viz. D-isoleucine, L-alanine, D-phenylalanine, and D-serine and two modified amino acids viz. thiazole and oxazole. Raocyclamide A (42) differed from raocyclamide B (43) in having an additional heterocyclic ring "oxazoline" with a D-configuration instead of a D-serine residue. Raocyclamide A (42) was found to be moderately cytotoxic against sea urchin embryos [32] (Figure 14).

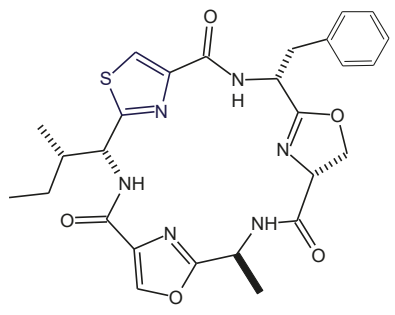

42

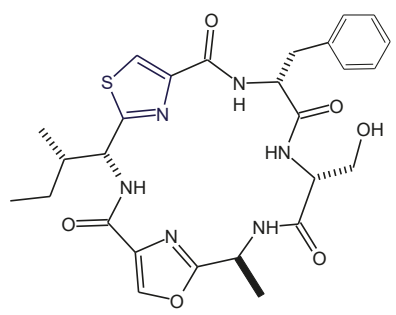

43

Figure 14. Structures of raocyclamide A (42) and raocyclamide B (43) with D-Ile-Tzl residues.

The ascidian-derived lissoclinamides 1-10 and cyanobacterium-derived tenuecyclamide A and B are other cyclopolypeptides containing thiazole, thiazoline, methyloxazole, and methyloxazoline rings which displayed cytotoxicity against SV40 transformed fibroblasts and transitional bladder carcinoma cells as well as inhibited the division of sea urchin embryos [102-105].

Various heterocyclic marine-derived thiazole-based cyclopolypeptides including those having thiazoline $(\mathrm{Tzn})$, oxazole $(\mathrm{Ozl})$, oxazoline $(\mathrm{Ozn})$, 5-methyloxazole (mOzl), 5-methyloxazoline (mOzn), 5-hydroxytryptophan (Htrp), N-methylimidazole (mImz), histidine (His), tryptophan (Trp), 2-bromo-5-hydroxytryptophan (Bhtrp), and N-methyltryptophan (Metrp) rings in addition to thiazole, together with their molecular formulas and composition, are tabulated in Table 1.

Table 1. Heterocyclic thiazole-based cyclopolypeptides from marine resources.

\begin{tabular}{|c|c|c|c|c|}
\hline Year & Cyclic Peptide & $\begin{array}{l}\text { Molecular } \\
\text { Formula }\end{array}$ & Composition & $\begin{array}{c}\text { Heterocyclic } \\
\text { Ring (s) * }\end{array}$ \\
\hline 1980 & Ulicyclamide [53] & $\mathrm{C}_{33} \mathrm{H}_{39} \mathrm{~N}_{7} \mathrm{O}_{5} \mathrm{~S}_{2}$ & cyclooligopeptide & Tzl, mOzn \\
\hline 1980 & Ulithiacyclamide [53] & $\mathrm{C}_{32} \mathrm{H}_{42} \mathrm{~N}_{8} \mathrm{O}_{6} \mathrm{~S}_{4}$ & bicyclic peptide & $\mathrm{Tzl}, \mathrm{mOzn}$ \\
\hline 1982 & Patellamide A [39] & $\mathrm{C}_{35} \mathrm{H}_{50} \mathrm{~N}_{8} \mathrm{O}_{6} \mathrm{~S}_{2}$ & cyclooctapeptide & Tzl, Ozn, mOzn \\
\hline 1982 & Patellamide B [39] & $\mathrm{C}_{38} \mathrm{H}_{48} \mathrm{~N}_{8} \mathrm{O}_{6} \mathrm{~S}_{2}$ & cyclooctapeptide & Tzl, mOzn \\
\hline 1982 & Patellamide C [39] & $\mathrm{C}_{37} \mathrm{H}_{46} \mathrm{~N}_{8} \mathrm{O}_{6} \mathrm{~S}_{2}$ & cyclooctapeptide & Tzl, mOzn \\
\hline 1983 & Ascidiacyclamide [106] & $\mathrm{C}_{36} \mathrm{H}_{52} \mathrm{~N}_{8} \mathrm{O}_{6} \mathrm{~S}_{2}$ & cyclopolypeptide & $\mathrm{Tzl}, \mathrm{mOzn}$ \\
\hline 1989 & Lissoclinamide 4 [56] & $\mathrm{C}_{38} \mathrm{H}_{43} \mathrm{~N}_{7} \mathrm{O}_{5} \mathrm{~S}_{2}$ & cycloheptapeptide & Tzl, Tzn, mOzn \\
\hline 1989 & Lissoclinamide 5 [56] & $\mathrm{C}_{38} \mathrm{H}_{41} \mathrm{~N}_{7} \mathrm{O}_{5} \mathrm{~S}_{2}$ & cycloheptapeptide & $\mathrm{Tzl}, \mathrm{mOzn}$ \\
\hline 1989 & Ulithiacyclamide B [57] & $\mathrm{C}_{35} \mathrm{H}_{40} \mathrm{~N}_{8} \mathrm{O}_{6} \mathrm{~S}_{4}$ & bicycle peptide & Tzl, mOzn \\
\hline 1989 & Patellamide D [80] & $\mathrm{C}_{38} \mathrm{H}_{48} \mathrm{~N}_{8} \mathrm{O}_{6} \mathrm{~S}_{2}$ & cyclooctapeptide & $\mathrm{Tzl}, \mathrm{mOzn}$ \\
\hline 1990 & Lissoclinamide 8 [55] & $\mathrm{C}_{38} \mathrm{H}_{43} \mathrm{~N}_{7} \mathrm{O}_{5} \mathrm{~S}_{2}$ & cycloheptapeptide & Tzl, Tzn, mOzn \\
\hline 1990 & Lissoclinamide 7 [55] & $\mathrm{C}_{38} \mathrm{H}_{45} \mathrm{~N}_{7} \mathrm{O}_{5} \mathrm{~S}_{2}$ & cycloheptapeptide & Tzn, mOzn \\
\hline 1992 & Tawicyclamide A [41] & $\mathrm{C}_{39} \mathrm{H}_{51} \mathrm{~N}_{8} \mathrm{O}_{5} \mathrm{~S}_{3}$ & cyclooctapeptide & Tzl, Tzn \\
\hline 1992 & Tawicyclamide B [41] & $\mathrm{C}_{36} \mathrm{H}_{53} \mathrm{~N}_{8} \mathrm{O}_{5} \mathrm{~S}_{3}$ & cyclooctapeptide & Tzl, Tzn \\
\hline 1992 & Patellamide E [58] & $\mathrm{C}_{39} \mathrm{H}_{50} \mathrm{~N}_{8} \mathrm{O}_{6} \mathrm{~S}_{2}$ & cyclooctapeptide & Tzl, mOzn \\
\hline 1992 & Bistratamide C [59] & $\mathrm{C}_{22} \mathrm{H}_{26} \mathrm{~N}_{6} \mathrm{O}_{4} \mathrm{~S}_{2}$ & cyclohexapeptide & Tzl, Ozl \\
\hline
\end{tabular}


Table 1. Cont.

\begin{tabular}{|c|c|c|c|c|}
\hline Year & Cyclic Peptide & $\begin{array}{l}\text { Molecular } \\
\text { Formula }\end{array}$ & Composition & $\begin{array}{c}\text { Heterocyclic } \\
\text { Ring (s) * }\end{array}$ \\
\hline 1992 & Bistratamide D [59] & $\mathrm{C}_{25} \mathrm{H}_{34} \mathrm{~N}_{6} \mathrm{O}_{5} \mathrm{~S}$ & cyclohexapeptide & Tzl, Ozl, mOzn \\
\hline 1995 & Keramamide J [67] & $\mathrm{C}_{33} \mathrm{H}_{58} \mathrm{~N}_{10} \mathrm{O}_{11} \mathrm{~S}$ & cyclopolypeptide & Tzl, Trp \\
\hline 1995 & Keramamide G [67] & $\mathrm{C}_{43} \mathrm{H}_{56} \mathrm{~N}_{10} \mathrm{O}_{11} \mathrm{~S}$ & cyclopolypeptide & Tzl, Htrp \\
\hline 1995 & Keramamide H [67] & $\mathrm{C}_{43} \mathrm{H}_{57} \mathrm{~N}_{10} \mathrm{O}_{12} \mathrm{BrS}$ & cyclopolypeptide & Tzl, Bhtrp \\
\hline 1995 & Cyclodidemnamide [62] & $\mathrm{C}_{34} \mathrm{H}_{43} \mathrm{~N}_{7} \mathrm{O}_{5} \mathrm{~S}_{2}$ & cycloheptapeptide & Tzl, Tzn, Ozn \\
\hline 1995 & Dolastatin E [76] & $\mathrm{C}_{21} \mathrm{H}_{26} \mathrm{~N}_{6} \mathrm{O}_{4} \mathrm{~S}_{2}$ & cyclohexapeptide & Tzl, Tzn, Ozl \\
\hline 1995 & Lissoclinamide 3 [54] & $\mathrm{C}_{33} \mathrm{H}_{41} \mathrm{~N}_{7} \mathrm{O}_{5} \mathrm{~S}_{2}$ & cycloheptapeptide & Tzl, mOzn \\
\hline 1995 & Patellamide F [54] & $\mathrm{C}_{37} \mathrm{H}_{46} \mathrm{~N}_{8} \mathrm{O}_{6} \mathrm{~S}_{2}$ & cyclooctapeptide & Tzl, Ozn, mOzn \\
\hline 1995 & Nostocyclamide [107] & $\mathrm{C}_{27} \mathrm{H}_{32} \mathrm{~N}_{6} \mathrm{O}_{6} \mathrm{~S}$ & cyclohexapeptide & Tzl, mOzl \\
\hline 1996 & Waiakeamide $[66,108]$ & $\mathrm{C}_{37} \mathrm{H}_{49} \mathrm{~N}_{7} \mathrm{O}_{8} \mathrm{~S}_{3}$ & cyclohexapeptide & Tzl \\
\hline 1996 & Raocyclamide B [32] & $\mathrm{C}_{27} \mathrm{H}_{32} \mathrm{~N}_{6} \mathrm{O}_{6} \mathrm{~S}$ & cyclohexapeptide & Tzl, Ozl \\
\hline 1996 & Raocyclamide A [32] & $\mathrm{C}_{27} \mathrm{H}_{30} \mathrm{~N}_{6} \mathrm{O}_{5} \mathrm{~S}$ & cyclohexapeptide & Tzl, Ozl, Ozn \\
\hline 1996 & Dendramide A [40] & $\mathrm{C}_{21} \mathrm{H}_{24} \mathrm{~N}_{6} \mathrm{O}_{4} \mathrm{~S}_{2}$ & cyclohexapeptide & Tzl, mOzl \\
\hline 1996 & Dendramide B [40] & $\mathrm{C}_{21} \mathrm{H}_{24} \mathrm{~N}_{6} \mathrm{O}_{4} \mathrm{~S}_{3}$ & cyclohexapeptide & Tzl, mOzl \\
\hline 1996 & Dendramide C [40] & $\mathrm{C}_{21} \mathrm{H}_{24} \mathrm{~N}_{6} \mathrm{O}_{5} \mathrm{~S}_{3}$ & cyclohexapeptide & Tzl, mOzl \\
\hline 1997 & Oriamide [65] & $\mathrm{C}_{44} \mathrm{H}_{54} \mathrm{~N}_{15} \mathrm{O}_{9} \mathrm{~S}_{2} \mathrm{Na}$ & cyclopolypeptide & Tzl \\
\hline 1997 & Dolastatin I [75] & $\mathrm{C}_{24} \mathrm{H}_{32} \mathrm{~N}_{6} \mathrm{O}_{5} \mathrm{~S}$ & cyclohexapeptide & Tzl, mOzl, Ozn \\
\hline 1998 & Ulithiacyclamide E [51] & $\mathrm{C}_{35} \mathrm{H}_{44} \mathrm{~N}_{8} \mathrm{O}_{8} \mathrm{~S}_{4}$ & bicyclic peptide & Tzl \\
\hline 1998 & Comoramide B [45] & $\mathrm{C}_{34} \mathrm{H}_{50} \mathrm{~N}_{6} \mathrm{O}_{7} \mathrm{~S}$ & cyclohexapeptide & Tzn \\
\hline 1998 & Mayotamide A [45] & $\mathrm{C}_{30} \mathrm{H}_{43} \mathrm{~N}_{7} \mathrm{O}_{4} \mathrm{~S}_{4}$ & cycloheptapeptide & Tzl, Tzn \\
\hline 1998 & Mayotamide B [45] & $\mathrm{C}_{29} \mathrm{H}_{41} \mathrm{~N}_{7} \mathrm{O}_{4} \mathrm{~S}_{4}$ & cycloheptapeptide & Tzl, Tzn \\
\hline 1998 & Keramamide K [109] & $\mathrm{C}_{44} \mathrm{H}_{60} \mathrm{~N}_{10} \mathrm{O}_{11} \mathrm{~S}$ & cyclopolypeptide & Tzl, Metrp \\
\hline 1998 & Ulithiacyclamide F [51] & $\mathrm{C}_{35} \mathrm{H}_{42} \mathrm{~N}_{8} \mathrm{O}_{7} \mathrm{~S}_{4}$ & bicycle peptide & Tzl, mOzn \\
\hline 1998 & Ulithiacyclamide G [51] & $\mathrm{C}_{35} \mathrm{H}_{42} \mathrm{~N}_{8} \mathrm{O}_{7} \mathrm{~S}_{4}$ & bicycle peptide & Tzl, mOzn \\
\hline 1998 & Comoramide A [45] & $\mathrm{C}_{34} \mathrm{H}_{48} \mathrm{~N}_{6} \mathrm{O}_{6} \mathrm{~S}$ & cyclohexapeptide & Tzn, mOzn \\
\hline 1998 & Patellamide G [51] & $\mathrm{C}_{38} \mathrm{H}_{50} \mathrm{~N}_{8} \mathrm{O}_{7} \mathrm{~S}_{2}$ & cyclooctapeptide & Tzl, mOzn \\
\hline 1998 & Tenuecyclamide A [105] & $\mathrm{C}_{19} \mathrm{H}_{20} \mathrm{~N}_{6} \mathrm{O}_{4} \mathrm{~S}_{2}$ & cyclohexapeptide & Tzl, mOzl \\
\hline 1998 & Tenuecyclamide C [105] & $\mathrm{C}_{20} \mathrm{H}_{22} \mathrm{~N}_{6} \mathrm{O}_{4} \mathrm{~S}_{3}$ & cyclohexapeptide & Tzl, mOzl \\
\hline 1998 & Tenuecyclamide D [105] & $\mathrm{C}_{20} \mathrm{H}_{22} \mathrm{~N}_{6} \mathrm{O}_{5} \mathrm{~S}_{3}$ & cyclohexapeptide & Tzl, mOzl \\
\hline 2000 & Haligramide A [63] & $\mathrm{C}_{37} \mathrm{H}_{49} \mathrm{~N}_{7} \mathrm{O}_{6} \mathrm{~S}$ & cyclohexapeptide & Tzl \\
\hline 2000 & Haligramide B [63] & $\mathrm{C}_{37} \mathrm{H}_{49} \mathrm{~N}_{7} \mathrm{O}_{7} \mathrm{~S}$ & cyclohexapeptide & Tzl \\
\hline 2000 & Dolastatin 3 [9] & $\mathrm{C}_{25} \mathrm{H}_{36} \mathrm{~N}_{6} \mathrm{O}_{5} \mathrm{~S}_{2}$ & cyclopentapeptide & Tzl \\
\hline 2000 & Homodolastatin 3 [9] & $\mathrm{C}_{30} \mathrm{H}_{42} \mathrm{~N}_{8} \mathrm{O}_{6} \mathrm{~S}_{2}$ & cyclopentapeptide & Tzl \\
\hline 2000 & Lyngbyabellin A [27] & $\mathrm{C}_{29} \mathrm{H}_{40} \mathrm{~N}_{4} \mathrm{O}_{7} \mathrm{~S}_{2} \mathrm{Cl}_{2}$ & cyclodepsipeptide & $\mathrm{Tzl}$ \\
\hline 2000 & Lyngbyabellin B [86] & $\mathrm{C}_{28} \mathrm{H}_{40} \mathrm{~N}_{4} \mathrm{O}_{7} \mathrm{~S}_{2} \mathrm{Cl}_{2}$ & cyclodepsipeptide & Tzl, Tzn \\
\hline 2000 & Kororamide [9] & $\mathrm{C}_{45} \mathrm{H}_{64} \mathrm{~N}_{10} \mathrm{O}_{10} \mathrm{~S}_{2}$ & cyclononapeptide & Tzl, Tzn \\
\hline 2000 & Lissoclinamide 9 [52] & $\mathrm{C}_{35} \mathrm{H}_{45} \mathrm{~N}_{7} \mathrm{O}_{5} \mathrm{~S}_{2}$ & cycloheptapeptide & Tzl, Tzn, mOzn \\
\hline 2000 & Ceratospongamide [77] & $\mathrm{C}_{41} \mathrm{H}_{49} \mathrm{~N}_{7} \mathrm{O}_{6} \mathrm{~S}$ & cycloheptapeptide & Tzl, mOzn \\
\hline 2000 & Microcyclamide [35] & $\mathrm{C}_{26} \mathrm{H}_{30} \mathrm{~N}_{8} \mathrm{O}_{4} \mathrm{~S}_{2}$ & cyclohexapeptide & Tzl, mOzl, mImz \\
\hline 2001 & Nostocyclamide M [36] & $\mathrm{C}_{20} \mathrm{H}_{22} \mathrm{~N}_{6} \mathrm{O}_{4} \mathrm{~S}_{3}$ & cyclohexapeptide & Tzl, mOzl \\
\hline 2002 & Cyclodidemnamide B [42] & $\mathrm{C}_{32} \mathrm{H}_{47} \mathrm{~N}_{7} \mathrm{O}_{6} \mathrm{~S}_{2}$ & cycloheptapeptide & Tzl \\
\hline 2002 & Obyanamide [12] & $\mathrm{C}_{30} \mathrm{H}_{41} \mathrm{~N}_{5} \mathrm{O}_{6} \mathrm{~S}$ & cyclodepsipeptide & Tzl \\
\hline 2002 & Ulongamide A [13] & $\mathrm{C}_{32} \mathrm{H}_{45} \mathrm{~N}_{5} \mathrm{O}_{6} \mathrm{~S}$ & cyclodepsipeptide & Tzl \\
\hline 2002 & Ulongamide D [13] & $\mathrm{C}_{34} \mathrm{H}_{49} \mathrm{~N}_{5} \mathrm{O}_{7} \mathrm{~S}$ & cyclodepsipeptide & Tzl \\
\hline 2002 & Ulongamide E [13] & $\mathrm{C}_{35} \mathrm{H}_{51} \mathrm{~N}_{5} \mathrm{O}_{7} \mathrm{~S}$ & cyclodepsipeptide & Tzl \\
\hline 2002 & Ulongamide B [13] & $\mathrm{C}_{32} \mathrm{H}_{45} \mathrm{~N}_{5} \mathrm{O}_{7} \mathrm{~S}$ & cyclodepsipeptide & Tzl \\
\hline
\end{tabular}


Table 1. Cont.

\begin{tabular}{|c|c|c|c|c|}
\hline Year & Cyclic Peptide & $\begin{array}{l}\text { Molecular } \\
\text { Formula }\end{array}$ & Composition & $\begin{array}{c}\text { Heterocyclic } \\
\text { Ring (s) * }\end{array}$ \\
\hline 2002 & Ulongamide C [13] & $\mathrm{C}_{36} \mathrm{H}_{45} \mathrm{~N}_{5} \mathrm{O}_{7} \mathrm{~S}$ & cyclodepsipeptide & Tzl \\
\hline 2002 & Ulongamide F [13] & $\mathrm{C}_{30} \mathrm{H}_{49} \mathrm{~N}_{5} \mathrm{O}_{6} \mathrm{~S}$ & cyclodepsipeptide & Tzl \\
\hline 2002 & Banyascyclamide B [11] & $\mathrm{C}_{22} \mathrm{H}_{30} \mathrm{~N}_{6} \mathrm{O}_{5} \mathrm{~S}_{2}$ & cyclohexapeptide & Tzl \\
\hline 2002 & Banyascyclamide C [11] & $\mathrm{C}_{25} \mathrm{H}_{28} \mathrm{~N}_{6} \mathrm{O}_{5} \mathrm{~S}_{2}$ & cyclohexapeptide & Tzl \\
\hline 2002 & Banyascyclamide A [11] & $\mathrm{C}_{25} \mathrm{H}_{26} \mathrm{~N}_{6} \mathrm{O}_{4} \mathrm{~S}_{2}$ & cyclohexapeptide & Tzl, mOzn \\
\hline 2002 & Leucamide A [70] & $\mathrm{C}_{29} \mathrm{H}_{37} \mathrm{~N}_{7} \mathrm{O}_{6} \mathrm{~S}$ & cycloheptapeptide & Tzl, Ozl, mOzl \\
\hline 2003 & Guineamide A [14] & $\mathrm{C}_{31} \mathrm{H}_{44} \mathrm{~N}_{5} \mathrm{O}_{6} \mathrm{~S}$ & cyclodepsipeptide & $\mathrm{Tzl}$ \\
\hline 2003 & Guineamide B [14] & $\mathrm{C}_{32} \mathrm{H}_{45} \mathrm{~N}_{5} \mathrm{O}_{6} \mathrm{~S}$ & cyclodepsipeptide & Tzl \\
\hline 2003 & Didmolamide A [48] & $\mathrm{C}_{25} \mathrm{H}_{26} \mathrm{~N}_{6} \mathrm{O}_{4} \mathrm{~S}_{2}$ & cyclohexapeptide & Tzl \\
\hline 2003 & Didmolamide B [48] & $\mathrm{C}_{25} \mathrm{H}_{28} \mathrm{~N}_{6} \mathrm{O}_{5} \mathrm{~S}_{2}$ & cyclohexapeptide & $\mathrm{Tzl}$ \\
\hline 2003 & Bistratamide J [50] & $\mathrm{C}_{25} \mathrm{H}_{36} \mathrm{~N}_{6} \mathrm{O}_{5} \mathrm{~S}_{2}$ & cyclohexapeptide & Tzl \\
\hline 2003 & Bistratamide I [50] & $\mathrm{C}_{25} \mathrm{H}_{36} \mathrm{~N}_{6} \mathrm{O}_{5} \mathrm{~S}_{2}$ & cyclohexapeptide & Tzl, Ozl \\
\hline 2003 & Bistratamide H [50] & $\mathrm{C}_{25} \mathrm{H}_{32} \mathrm{~N}_{6} \mathrm{O}_{4} \mathrm{~S}_{2}$ & cyclohexapeptide & Tzl, mOzl \\
\hline 2003 & Bistratamide E [50] & $\mathrm{C}_{25} \mathrm{H}_{34} \mathrm{~N}_{6} \mathrm{O}_{4} \mathrm{~S}_{2}$ & cyclohexapeptide & Tzl, mOzn \\
\hline 2003 & Bistratamide G [50] & $\mathrm{C}_{25} \mathrm{H}_{32} \mathrm{~N}_{6} \mathrm{O}_{5} \mathrm{~S}$ & cyclohexapeptide & Tzl, Ozl, mOzl \\
\hline 2003 & Bistratamide F [50] & $\mathrm{C}_{26} \mathrm{H}_{36} \mathrm{~N}_{6} \mathrm{O}_{5} \mathrm{~S}$ & cyclohexapeptide & Tzl, Ozn, mOzn \\
\hline 2003 & Myriastramide C [69] & $\mathrm{C}_{42} \mathrm{H}_{53} \mathrm{~N}_{9} \mathrm{O}_{7} \mathrm{~S}$ & cyclooctapeptide & Tzl, Ozl, Trp \\
\hline 2003 & Bistratamide B [60] & $\mathrm{C}_{27} \mathrm{H}_{32} \mathrm{~N}_{6} \mathrm{O}_{4} \mathrm{~S}_{2}$ & cyclohexapeptide & Tzl, Tzn, mOzn \\
\hline 2004 & Scleritodermin A [64] & $\mathrm{C}_{42} \mathrm{H}_{54} \mathrm{~N}_{7} \mathrm{O}_{10} \mathrm{SNa}$ & cyclopolypeptide & Tzl \\
\hline 2005 & Lyngbyabellin E [28] & $\mathrm{C}_{37} \mathrm{H}_{51} \mathrm{~N}_{3} \mathrm{O}_{12} \mathrm{~S}_{2} \mathrm{Cl}_{2}$ & cyclodepsipeptide & Tzl \\
\hline 2005 & Lyngbyabellin H [28] & $\mathrm{C}_{37} \mathrm{H}_{51} \mathrm{~N}_{3} \mathrm{O}_{11} \mathrm{~S}_{2} \mathrm{Cl}_{2}$ & cyclodepsipeptide & Tzl \\
\hline 2005 & Mechercharmycin A [79] & $\mathrm{C}_{35} \mathrm{H}_{32} \mathrm{~N}_{8} \mathrm{O}_{7} \mathrm{~S}$ & cyclooligopeptide & Tzl, Ozl \\
\hline 2006 & Trichamide [17] & $\mathrm{C}_{44} \mathrm{H}_{66} \mathrm{~N}_{16} \mathrm{O}_{12} \mathrm{~S}_{2}$ & cyclopolypeptide & Tzl, His \\
\hline 2007 & Urukthapelstatin A [78] & $\mathrm{C}_{34} \mathrm{H}_{30} \mathrm{~N}_{8} \mathrm{O}_{6} \mathrm{~S}_{2}$ & cyclooligopeptide & Tzl, Ozl \\
\hline 2007 & Venturamide A [34] & $\mathrm{C}_{21} \mathrm{H}_{24} \mathrm{~N}_{6} \mathrm{O}_{4} \mathrm{~S}_{2}$ & cyclohexapeptide & Tzl, mOzl \\
\hline 2007 & Venturamide B [34] & $\mathrm{C}_{22} \mathrm{H}_{26} \mathrm{~N}_{6} \mathrm{O}_{5} \mathrm{~S}_{2}$ & cyclohexapeptide & Tzl, mOzl \\
\hline 2008 & Mollamide C [46] & $\mathrm{C}_{30} \mathrm{H}_{46} \mathrm{~N}_{6} \mathrm{O}_{6} \mathrm{~S}$ & cyclohexapeptide & Tzl \\
\hline 2008 & Aerucyclamide B [37] & $\mathrm{C}_{24} \mathrm{H}_{33} \mathrm{~N}_{6} \mathrm{O}_{4} \mathrm{~S}_{2}$ & cyclohexapeptide & Tzl, mOzn \\
\hline 2008 & Aerucyclamide A [37] & $\mathrm{C}_{24} \mathrm{H}_{34} \mathrm{~N}_{6} \mathrm{O}_{4} \mathrm{~S}_{2}$ & cyclohexapeptide & Tzl, Tzn, mOzn \\
\hline 2008 & Aerucyclamide D [38] & $\mathrm{C}_{26} \mathrm{H}_{31} \mathrm{~N}_{6} \mathrm{O}_{4} \mathrm{~S}_{3}$ & cyclohexapeptide & Tzl, Tzn, mOzn \\
\hline 2008 & Aerucyclamide C [38] & $\mathrm{C}_{24} \mathrm{H}_{32} \mathrm{~N}_{6} \mathrm{O}_{5} \mathrm{~S}$ & cyclohexapeptide & Tzl, Ozl, mOzn \\
\hline 2009 & Sanguinamide A [73] & $\mathrm{C}_{37} \mathrm{H}_{52} \mathrm{~N}_{7} \mathrm{O}_{6} \mathrm{~S}$ & cycloheptapeptide & Tzl \\
\hline 2009 & Sanguinamide B [73] & $\mathrm{C}_{33} \mathrm{H}_{43} \mathrm{~N}_{8} \mathrm{O}_{6} \mathrm{~S}_{2}$ & cyclooctapeptide & Tzl, Ozl \\
\hline 2010 & Microcyclamide MZ602 [18] & $\mathrm{C}_{28} \mathrm{H}_{38} \mathrm{~N}_{6} \mathrm{O}_{7} \mathrm{~S}$ & cyclohexapeptide & Tzl \\
\hline 2010 & Microcyclamide MZ568 [18] & $\mathrm{C}_{25} \mathrm{H}_{40} \mathrm{~N}_{6} \mathrm{O}_{7} \mathrm{~S}$ & cyclohexapeptide & Tzl \\
\hline 2010 & Aeruginazole A [91] & $\mathrm{C}_{53} \mathrm{H}_{66} \mathrm{~N}_{13} \mathrm{O}_{11} \mathrm{~S}_{3}$ & cyclododecapeptide & Tzl \\
\hline 2010 & Lyngbyabellin J [30] & $\mathrm{C}_{37} \mathrm{H}_{51} \mathrm{~N}_{3} \mathrm{O}_{12} \mathrm{~S}_{2} \mathrm{Cl}_{2}$ & cyclodepsipeptide & $\mathrm{Tzl}$ \\
\hline 2010 & 27-deoxylyngbyabellin A [30] & $\mathrm{C}_{29} \mathrm{H}_{40} \mathrm{~N}_{4} \mathrm{O}_{6} \mathrm{~S}_{2} \mathrm{Cl}_{2}$ & cyclodepsipeptide & Tzl \\
\hline 2012 & Aeruginazole DA1497 [8] & $\mathrm{C}_{68} \mathrm{H}_{91} \mathrm{~N}_{17} \mathrm{NaO}_{14} \mathrm{~S}_{4}$ & cyclopolypeptide & Tzl \\
\hline 2012 & Aeruginazole DA1304 [8] & $\mathrm{C}_{61} \mathrm{H}_{72} \mathrm{~N}_{14} \mathrm{NaO}_{13} \mathrm{~S}_{3}$ & cyclopolypeptide & Tzl \\
\hline 2012 & Aeruginazole DA1274 [8] & $\mathrm{C}_{60} \mathrm{H}_{70} \mathrm{~N}_{14} \mathrm{NaO}_{12} \mathrm{~S}_{3}$ & cyclopolypeptide & Tzl \\
\hline 2012 & Lyngbyabellin N [29] & $\mathrm{C}_{40} \mathrm{H}_{58} \mathrm{~N}_{4} \mathrm{O}_{11} \mathrm{~S}_{2} \mathrm{Cl}_{2}$ & cyclodepsipeptide & Tzl \\
\hline 2012 & Largazole [16] & $\mathrm{C}_{29} \mathrm{H}_{38} \mathrm{~N}_{4} \mathrm{O}_{5} \mathrm{~S}_{3}$ & cyclodepsipeptide & Tzl, Tzn \\
\hline 2012 & Marthiapeptide A [74] & $\mathrm{C}_{30} \mathrm{H}_{31} \mathrm{~N}_{7} \mathrm{O}_{3} \mathrm{~S}_{4}$ & cyclooligopeptide & Tzl, Tzn \\
\hline 2012 & Calyxamide A [110] & $\mathrm{C}_{45} \mathrm{H}_{61} \mathrm{~N}_{11} \mathrm{O}_{12} \mathrm{~S}$ & cyclooligopeptide & Tzl, Htrp \\
\hline
\end{tabular}


Table 1. Cont.

\begin{tabular}{ccccc}
\hline Year & Cyclic Peptide & $\begin{array}{c}\text { Molecular } \\
\text { Formula }\end{array}$ & Composition & $\begin{array}{c}\text { Heterocyclic } \\
\text { Ring (s) }\end{array}$ \\
\hline 2012 & Calyxamide B [110] & $\mathrm{C}_{45} \mathrm{H}_{61} \mathrm{~N}_{11} \mathrm{O}_{12} \mathrm{~S}$ & cyclooligopeptide & Tzl, Htrp \\
\hline 2013 & Aestuaramide A [10] & $\mathrm{C}_{40} \mathrm{H}_{51} \mathrm{~N}_{7} \mathrm{O}_{6} \mathrm{~S}_{3}$ & cyclopolypeptide & Tzl \\
\hline 2013 & Aestuaramide B [10] & $\mathrm{C}_{35} \mathrm{H}_{43} \mathrm{~N}_{7} \mathrm{O}_{6} \mathrm{~S}_{3}$ & cyclopolypeptide & Tzl \\
\hline 2013 & Aestuaramide C [10] & $\mathrm{C}_{40} \mathrm{H}_{51} \mathrm{~N}_{7} \mathrm{O}_{6} \mathrm{~S}_{3}$ & cyclopolypeptide & Tzl \\
\hline 2014 & Balgacyclamide A [33] & $\mathrm{C}_{25} \mathrm{H}_{37} \mathrm{~N}_{6} \mathrm{O}_{5} \mathrm{~S}$ & cyclooligopeptide & Tzl, mOzn \\
\hline 2014 & Balgacyclamide B [33] & $\mathrm{C}_{25} \mathrm{H}_{39} \mathrm{~N}_{6} \mathrm{O}_{6} \mathrm{~S}$ & cyclooligopeptide & Tzl, mOzn \\
\hline 2014 & Balgacyclamide C [33] & $\mathrm{C}_{28} \mathrm{H}_{37} \mathrm{~N}_{6} \mathrm{O}_{6} \mathrm{~S}$ & cyclooligopeptide & Tzl, mOzn \\
\hline 2016 & Jamaicensamide A [89] & $\mathrm{C}_{45} \mathrm{H}_{61} \mathrm{~N}_{9} \mathrm{O}_{10} \mathrm{~S}$ & cyclooligopeptide & Tzl, Htrp \\
\hline 2017 & Cyclotheonellazole A [68] & $\mathrm{C}_{44} \mathrm{H}_{54} \mathrm{~N}_{9} \mathrm{O}_{14} \mathrm{~S}_{2} \mathrm{Na}_{2}$ & cyclopolypeptide & Tzl \\
\hline 2017 & Cyclotheonellazole B [68] & $\mathrm{C}_{45} \mathrm{H}_{57} \mathrm{~N}_{9} \mathrm{O}_{14} \mathrm{~S}_{2} \mathrm{Na}_{2}$ & cyclopolypeptide & Tzl \\
\hline 2017 & Cyclotheonellazole C [68] & $\mathrm{C}_{43} \mathrm{H}_{52} \mathrm{~N}_{9} \mathrm{O}_{14} \mathrm{~S}_{2} \mathrm{Na}_{2}$ & cyclopolypeptide & Tzl \\
\hline 2017 & Bistratamide M, N [61] & $\mathrm{C}_{21} \mathrm{H}_{24} \mathrm{~N}_{6} \mathrm{O}_{4} \mathrm{~S}_{2}$ & cyclohexapeptide & Tzl, Ozl \\
\hline
\end{tabular}

* Tzl: Thiazole, Tzn: Thiazoline, Ozl: Oxazole, Ozn: Oxazoline, mOzl: 5-methyloxazole, mOzn:

5-methyloxazoline, Htrp: 5-hydroxytryptophan, mImz: N-methylimidazole, His: histidine, Trp: tryptophan,

Bhtrp: 2-bromo-5-hydroxytryptophan, Metrp: N-methyltryptophan.

\subsection{Structural Features of Thiopeptide Antibiotics}

Thiopeptides are a novel family of antibiotics which are associated with a lot of pharmacological properties including immunosuppressive, antineoplastic, antimalarial, and potent antimicrobial activity against Gram-positive bacteria. Due to their interesting structures and bioprofile against bacteria, thiopeptides have attracted the attention of researchers and scientists as a new class of emerging antibiotics. The most important characteristic feature of the thiopeptides is the central nitrogen-containing six-membered ring with diverse oxidation states. On the basis of different oxidation states of the central ring of thiopeptides, they can belong to the "a series" with a totally reduced central piperidine, the "b series" with a 1,2-dehydropiperidine ring, and the "c series" with a piperidine ring fused with imidazoline. All members of series $\mathrm{a}, \mathrm{b}$, and c have a macrocycle which contains a quinaldic acid moiety. The $\mathrm{d}$ series shows a trisubstituted pyridine ring, and the e series is known for the hydroxyl group in the central tetrasubstituted pyridine ring. The e series also presents a macrocycle formed by a modified 3,4-dimethylindolic acid moiety. The central ring in thiopeptides serves as a scaffold to at least one macrocycle and a tail, containing different thiazoles and oxazoles which are developed by dehydration/dehydrosulfanylation of amino acid like serine, cysteine, etc. TP-1161, YM-266183, YM-266184, kocurin, baringolin, geninthiocin, Ala-geninthiocin, and Val-geninthiocin are examples of thiopeptides from marine resources [111].

TP-1161 belongs to the " $\mathrm{d}$ series" of thiopeptide antibiotics, produced by a marine sediment-derived Nocardiopsis sp. Structural features of this thiopeptide include the three 2,4-disubstituted thiazoles and one 2,4-disubstituted oxazole moiety in addition to the presence of a trisubstitued pyridine (Pyr) functional unit and an unusual aminoacetone moiety. TP-1161 displayed good activity against a panel of Gram-positive bacteria including Staphylococcus aureus, Staphylococcus haemolyticus, Staphylococcus epidermidis, Enterococcus faecium, and Enterococcus faecalis [112].

YM-266183 and YM-266184 are novel thiopeptide antibiotics produced by Bacillus cereus isolated from a marine sponge and structurally related to a known family of antibiotics that include thiocillins and micrococcins. Structural analysis of these thiopeptides indicated the presence of several unusual amino acids with heteroaromatic moieties, including the six thiazole rings, a 2,3,6-trisubstituted pyridine residue to which three of thiazole units are attached, a 2-amino-2-butanoic acid unit with an aminoacetone residue, a (Z)-2-amino-2-butenoic acid unit attached to a threonine residue, and a 3-hydroxyvaline moiety. There was a close similarity in structures of YM-266183 and YM-266184 except for the presence of a methoxy group (C55) in YM-266184 instead of the hydroxy group of 
YM-266183. These new antibacterial substances were found to exhibit activity against drug-resistant bacteria [113].

Kocurin is a new anti-methicillin-resistant Staphylococcus aureus (MRSA) bioactive compound, belonging to the thiazolyl peptide family of antibiotics, obtained from sponge-derived Kocuria and Micrococcus spp. Structural analysis of this thiopeptide indicated the presence of several heteroaromatic moieties, including one thiazoline and four thiazole rings, one methyloxazole ring and a 2,3,6-trisubstituted pyridine residue to which two of thiazole units and one methyloxazole unit are attached, aromatic amino acids like phenylalanine and tyrosine, and two proline units. Kocurin was found to be closely related to two known thiazolyl peptide antibiotics with similar modes of action: GE37468A and GE2270. The antimicrobial activity profile of kocurin indicated the extreme potency against Gram-positive bacteria with minimum inhibitory concentration (MIC) values of $0.25-0.5 \mu \mathrm{g} / \mathrm{mL}$ against methicillin-resistant Staphylococcus aureus (MRSA) [114].

Baringolin is a novel thiopeptide of the d series, containing a central 2,3,6-trisubstituted pyridine, derived from fermentation of the marine-derived bacterium Kucuria sp. The macrocycle in baringolin contained three thiazoles - a methyloxazole and pyridine ring, a thiazoline ring with an $\alpha$-chiral center, and a pyrrolidine motif derived from a proline residue-in addition to three natural amino acids viz. tyrosine, phenylalanine, and asparagine. The long peptidic tail was found to be a pentapeptide containing three methylidenes resulting from dehydration of serine that is attached to the pyridine through a fourth thiazole. This thiopeptide displayed important antibacterial activity against Staphylococcus aureus, Micrococcus luteus, Propionibacterium acnes, and Bacillus subtilis at nanomolar concentrations [115].

Ala-geninthiocin, geninthiocin, and Val-geninthiocin are new broad-spectrum thiopeptide antibiotics produced from the cultured marine Streptomyces sp. Structural analysis of all three thiopeptides indicated the presence of heteroaromatic moieties, including one thiazole and two oxazole rings, one methyloxazole ring, and a 2,3,6-trisubstituted pyridine residue to which two of thiazole units are attached at the 2 and 3 positions, including proteinogenic amino acid viz. L-threonine. The peptide structure of Ala-geninthiocin is largely similar to geninthiocin, the only difference being the presence of an L-Alanine residue instead of dealanine at the C-terminal amide. Further, Val-geninthiocin contained L-valine moiety instead of L-hydroxyvaline of geninthiocin. Ala-geninthiocin was found to exhibit good activity against Gram-positive bacteria including Staphylococcus aureus, Bacillus subtilis, Mycobacterium smegmatis, and Micrococcus luteus as well as cytotoxicity against A549 human lung carcinoma cells. When compared to geninthiocin, Ala-geninthiocin displayed better cytotoxicity but antibiotic activity against Gram-positive bacteria was comparatively low. Val-geninthiocin was found to possess more antifungal activity against Mucor hiemalis and cytotoxicity against A549 human lung carcinoma cells and L929 murine fibrosarcoma in comparison to geninthiocin. Further, Ala-geninthiocin and Val-geninthiocin displayed weak to moderate antifungal activity against Candida albicans, whereas geninthiocin was inactive. Ala-geninthiocin and geninthiocin displayed moderate antibiotic activity against Gram-negative bacteria Chromobacterium violaceum, whereas val-geninthiocin was inactive [116].

\subsection{Structural Features of Bridged Heterocyclic Peptide Bicycles}

Bicyclic peptides form one of the promising platforms for drug development owing to their biocompatibility and chemical diversity to proteins. Bioactive bicyclic peptides exist as disulfide-bridged peptide bicycles (e.g., ulithiacyclamide A, B, E, F, and G), histidino-tyrosine bridged peptide bicycles (e.g., aciculitins A-C), histidino-alanine bridged peptide bicycles (e.g., Theonellamides A, B, C, F, and G and Theogrenamide) and are derived from marine sponges/tunicates, plants, and mushrooms.

Ulithiacyclamide $\mathrm{A}$ is a strong cytotoxic disulfide-bridged peptide bicycle characterized by a symmetrical dimeric structure consisting of oxazoline and thiazole rings in addition to a transannular disulfide isolated from marine tunicate/ascidian Lissoclinum patella. The structure of ulithiacyclamide B 
closely resembled the structure of ulithiacyclamide with the exception of the replacement of one of the two D-leucine units with D-phenylalanine residue, resulting in an asymmetrical dimeric structure. Because the configuration of both leucine and phenylalanine was $\mathrm{D}$, both thiazole amino acids possessed $R$ configurations in ulithiacyclamide. The structures of ulithiacyclamides E, F, and G are related in structure to ulithiacyclamide B but with either both (in the case of ulithiacyclamide E) or just one of the two (in the cases of ulithiacyclamides $\mathrm{F}$ and $\mathrm{G}$ ) oxazoline rings existing as their hydrolyzed L-threonine counterpart. Ulithiacyclamides $\mathrm{F}$ and $\mathrm{G}$ were found to be isomers and contained one oxazoline including one "free" threonine unit and were anhydro forms of ulithiacyclamide E. Ulithiacyclamide and ulithiacyclamide $\mathrm{B}$ exhibited cytotoxicity against the $\mathrm{KB}$ cell line with $\mathrm{IC}_{50}$ values of 35 and $17 \mathrm{ng} / \mathrm{mL}$, respectively $[51,53,56,57,117]$.

Aciculitins A-C are cytotoxic and antifungal glycopeptidolipids from the lithistid sponge Aciculites orientalis. They consist of a bicyclic peptide structure that contains a histidine-tyrosine bridge, with an unusual combination of tyrosine and histidine residues joined through the $3^{\prime}$-position of tyrosine and the $5^{\prime}$-position of histidine [118]. Theonegramide is a peculiar antifungal peptide that presents an intra-cycle histidine-alanine bridge in which the imidazole ring is substituted by a D-arabinose moiety. The alanine portion of histidinoalanine was found to have the $(R)$-configuration while the histidine portion with the (S)-configuration [119]. Theonellamides (TNMs) are members of a distinctive family of sterol-binding bioactive bicyclic dodecapeptides, with theonellamide $\mathrm{F}$ being a novel antifungal bicyclic dodecapeptide with an unprecedented histidinoalanine bridge composed of unusual amino acid residues like $\tau$-L-histidino-D-alanine, $(2 S, 4 R)$-2-amino-4-hydroxyadipic acid (Ahad), and (3S,4S,5E,7E)-3-amino-4-hydroxy-6-methyl-8- ( $p$-bromophenyl)-5,7-octadienoic acid (Aboa). Theonellamide $\mathrm{F}$ was found to be a useful agent for investigating membrane structures in cells and inhibited growth of various pathogenic fungi including Candida sp., Trichophyton sp., and Aspergillus sp. [120,121].

Moroidin is a unique bicyclic peptide bearing residues like histidine, tryptophan, arginine, and $\beta$-leucine, isolated from the seeds of the Chinese herb Celosia argentea (Amaranthaceae), that remarkably inhibited the polymerization of tubulin [122]. Celogentins are unique cyclopolypeptides containing a bicyclic ring system; an unusual $\mathrm{C}-\mathrm{N}$ bond formed by Trp and His residues; and an unusual amino acid, $\beta$-substituted Leu, isolated from the seeds of Celosia argentea. Celogentins $\mathrm{A}-\mathrm{C}$ inhibited the polymerization of tubulin, and celogentin $C$ was found to be 4 times more potent than moroidin in the inhibitory activity [123]. Phalloidin is a rigid bicyclic peptide containing an unusual cysteine-tryptophan linkage, isolated from the death cap mushroom Amanita phalloides. This cycloheptapeptide is commonly used in imaging applications to selectively label F-actin in fixed cells, permeabilized cells, and cell-free experiments [124]. $\alpha$-Amanitin is a highly toxic hydrophobic bicyclic octapeptide found in a genus of mushrooms known as Amanita, including Amanita phalloides, Amanita verna, and Amanita virosa. The cytotoxicity found in amanitin is the result of inhibition of RNA polymerases, in particular RNA polymerase II, which precludes mRNA synthesis [124].

\subsection{Structural Features of Other Heterocyclic Peptides from Marine Resources}

Azonazine is a unique anti-inflammatory peptide with a macrocyclic heterocyclic core of the benzofuro indole ring system with diketopiperazine residue and possesses structural similarity with diazonamide A. The absolute configuration of this marine sediment-derived fungus-originated complex peptide was established as $2 R, 10 R, 11 S, 19 R$. The first total synthesis of hexacyclic dipeptide ent-(-)-azonazine was accomplished using a hypervalent iodine-mediated biomimetic oxidative cyclization to construct the highly strained core [125].

The pyridine ring (in the form of 3-hydroxypicolinic acid, 3HyPic) also forms part of cyclopeptide structures such as fijimycins and etamycin. Fijimycins A-C are cyclic depsipeptides from a marine-derived Streptomyces sp. which possessed in vitro antibacterial activity against three methicillin-resistant Staphylococcus aureus (MRSA) strains. The depsipeptide fijimycin A was found to contain eight subunits including $\alpha$-phenylsarcosine (L-PhSar), $N$, $\beta$-dimethylleucine (L-DiMeLeu), 
sarcosine (Sar), 4-hydroxyproline (D-Hyp), and 3-hydroxypicolinic acid (3HyPic). Fijimycin A was defined as a stereoisomer of etamycin A containing $\mathrm{D}-\alpha$-phenylsarcosine. While comparing the structure of fijimycin B with fijimycin A, there was disappearance of $\alpha$-phenylsarcosine (PhSar) and the existence of an $\mathrm{N}$-methylleucine (L-NMeLeu) residue. Comparison of structures of fijimycins $\mathrm{C}$ and A suggested that the alanine (Ala) moiety in fijimycin A was replaced by a serine (Ser) unit. Etamycin A, also called virifogrisein I, was isolated from cultures of a terrestrial Streptomyces species which exhibited considerable activity against Gram-positive bacteria as well as Mycobacterium tuberculosis.

Fijimycins $\mathrm{A}$ and $\mathrm{C}$ and etamycin A exhibited strong antibiotic activities against the three MRSA strains (ATCC33591, Sanger 252, UAMS1182). However, fijimycin B showed weak inhibition against both ATCC33591 and UAMS1182, which indicated that the $\alpha$-phenylsarcosine unit might be vital for significant antibacterial activity. The similar antimicrobial activities of the stereoisomers fijimycin A and etamycin A suggested that substituting $\mathrm{D}$ - for $\mathrm{L}$ - $\alpha$-phenylsarcosine had little effect on the anti-MRSA activities [126].

Jaspamide $\mathrm{P}$ is a sponge-derived modified jaspamide derivative possessing antimicrofilament activity and characterised by a modification of the $N$-methylabrine ( $N$-methyl-2-bromotrypthophan) residue. Structural analysis of this cyclopeptide indicated the presence of a 4-methoxy-1,3-benzoxazine2-one heteroaromatic system. Jaspamide P was found to exhibit cytotoxic activity against HT-29 and MCF-7 tumour cell lines. Modifications of the methylabrine residue, claimed as essential for the observed biological activity, appeared to have little influence on the observed antiproliferative effect [127].

Wainunuamide is an unusual histidine containing cycloheptapeptide, containing three proline units. There were adjacent cis and trans proline residues in the structure of wainunuamide. Similar patterns were also found in cyclooligopeptide phakellistatin 8 and were found to be powerful $\beta$-turn inducers. The stereochemistry of all residues including histidine, phenylalanine, and leucine was found to be L. Wainunuamide exhibited weak cytotoxic activity in A2780 ovarian tumor and K562 leukemia cancer cells [128].

Ohmyungsamycins A and B are marine bacterium-derived cytotoxic and antimicrobial cyclic depsipeptides composed of 12 amino acid residues, including unusual amino acids such as $\mathrm{N}$-methyl-4-methoxy-L-tryptophan, $\beta$-hydroxy-L-phenylalanine, and $\mathrm{N}, \mathrm{N}$-dimethylvaline. Ohmyungsamycins A and B showed significant inhibitory activities against diverse cancer cells as well as antibacterial effects against both Gram-positive and Gram-negative bacteria. Sungsanpin is a serine-rich lasso peptide containing 15 amino acid units from a deep-sea streptomycete in which eight amino acids form a cyclic peptide and the remaining seven amino acids including L-tryptophan unit form a tail that loops through the ring. It is the first example of a lasso peptide from a marine-derived microorganism and displays inhibitory activity with the human lung cancer cell line A549 in a cell invasion assay [129].

Desotamide and destolamide B are L-tryptophan containing bioactive peptides from marine microbe Streptomyces scopuliridis SCSIO ZJ46. These cyclohexapeptides displayed good antibacterial activities against Streptococcus pnuemoniae, Staphylococcus aureus, and methicillin-resistant Staphylococcus epidermidis (MRSE). In a complementary fashion, the antibacterial activities of destolamides revealed the "Tryptophan" moiety to be essential, thereby highlighting a critical structural element to this advancing antibacterial scaffold [130].

\section{Stereochemical Aspects}

Stereochemistry includes the study of the relative arrangement of atoms or groups in a molecule in three-dimensional space and its understanding is crucial for the study of complex molecules like heterocyclic peptides, which are of paramount biological significance.

cis,cis- and trans,trans-ceratospongamides $(44,45)$ are new bioactive thiazole-containing cyclic heptapeptides from the marine red alga Ceratodictyon spongiosum and symbiotic sponge Sigmadocia symbiotica. The structures of ceratospongamides $(44,45)$ contained two L-phenylalanine residues, 
one (L-isoleucine)-L-methyloxazoline residue, one L-proline residue, and one (L-proline)thiazole residue and were found to be proline amide conformers. The change in conformation of a cyclooligopeptide ceratospongamide from "trans" to "cis" resulted in complete loss of bioactivity, e.g., trans, trans-isomer of ceratospongamide (45) was found to be a potent inhibitor of the expression of a key enzyme in the inflammatory cascade, secreted phospholipase $\mathrm{A}_{2}\left(\mathrm{sPLA}_{2}\right)$, with an $\mathrm{ED}_{50}$ of $32 \mathrm{nM}$ in a cell-based model for anti-inflammation, whereas cis,cis-isomer (44) was inactive [77] (Figure 15).

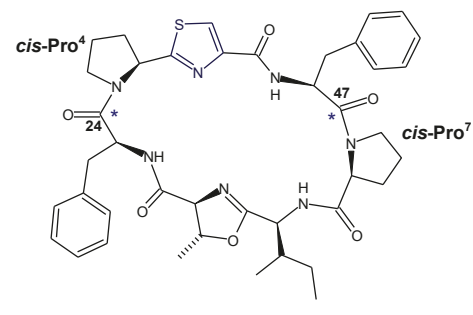

44

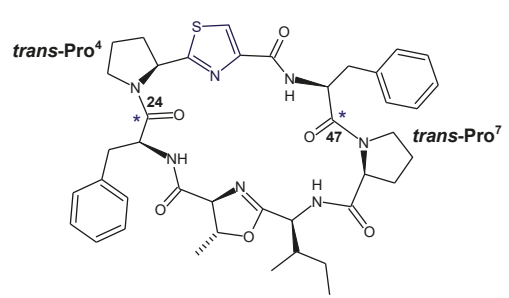

45

Figure 15. Structures of cis,cis-ceratospongamide (44) and trans,trans-ceratospongamide (45) with Pro-Tzl residues (*change in stereochemistry at C-24 and C-47 carbonyls).

Ulithiacyclamides are thiazole-containing cyclopolypeptides, isolated from the ascidian Lissoclinum patella. Bicyclic isomeric ulithiacyclamides F and G contained one oxazoline and one "free" threonine and were found to be anhydro forms of ulithiacyclamide E. Ulithiacyclamides F and G exhibited anti-multiple drug resistant (MDR) activity against vinblastine-resistant CCRF-CEM human leukemic lymphoblasts [51].

Lissoclinamides 4, 5, 7, and 8 are all cyclic heptapeptides derived from sea squirt Lissoclinum patella that have the same sequence of amino acids around the ring and differ from one another only in their stereochemistry or the number of thiazole and thiazoline rings. For lissoclinamide 8 , the valine residue was at position 31, the same sequence that occurs in lissoclinamide 4 . Therefore, the only difference between lissoclinamides 4 and 8 resided in the stereochemistry of one or two of the amino acids. The D configuration was assigned to "Phe-Tzl" and the L-configuration was assigned to "Val-Tzn" moiety in lissoclinamide 4 . However, both lissoclinamides 4 and 8 contained similar residues like L-Pro-mOzn and L-Phe. Further, there was similarity in the structural components of lissoclinamides 2 and 3; the only difference was in the stereochemistry around Ala-Tzl moiety, $\mathrm{D}$ in the case of the former and $\mathrm{L}$ in the latter $[55,56]$.

Lyngbyabellins are thiazole-containing halogenated peptolides derived from cyanobacteria, possessing cytotoxic properties. The configurations at C-15 and C-16 in lyngbyabellin A were found to be $15 S$ and $16 S$. Further, C-26 and C-3 in the peptolide has the $S$ configuration. The stereochemical assignments of lyngbyabellins $\mathrm{E}$ and $\mathrm{H}$ were found to be $2 S, 3 S, 14 R, 20 S, 26 R$, and 27S. The stereoconfigurations assigned to lyngbyabellin $\mathrm{N}$ was $2 S, 3 S, 14 R$, and $20 S$. The absolute configuration of the $N, N$-dimethylvaline (DiMeVal) residue in lyngbyabellin $\mathrm{N}$ was found to be $\mathrm{L}$, whereas the absolute configurations of the leucine statine were determined to be $3 R$ and $4 S$. The absolute configurations of lyngbyabellin J were found to be $2 S, 3 S, 14 R, 20 R, 21 S, 27 R$, and $28 S$. An overall cyclic constitution was not required for potent cytotoxic properties in lyngbyabellins as acyclic peptides like lyngbyabellins F and I also exhibited significant cytotoxic properties [27-30].

The cyclopolypeptides bistratamides $\mathrm{M}$ and $\mathrm{N}(46,47)$ were found to be isomers of each other and differed in the configuration of alanine residue attached to the thiazole ring. The configuration was $\mathrm{L}$ in bistratamide $M(46)$ and was found to be $\mathrm{D}$ in bistratamide $\mathrm{N}$ (47). Bistratamide $\mathrm{M}$ (46) was found to be slightly more cytotoxic against lung, breast, and pancreatic carcinoma cells in comparison to bistratamide N (47). Similarly, bistratamides K and L $(\mathbf{5 0 , 5 1 )}$ are isomers, differing in the configuration of alanine residue attached to the thiazole ring. The configuration was D in bistratamide K (50) and 
was found to be $\mathrm{L}$ in bistratamide L (51). Further, bistratamide G (39) was found to be O-isostere of bistratamide $\mathrm{H}$ (40) and bistratamide J was found to be $S$-isostere of bistratamide I (41). The compounds containing two thiazole rings were found to be more active than those containing a thiazole ring and an oxazole ring [50,61]. Moreover, the gross structure of cytotoxic cyclopeptide keramamide G (49) was found to be almost the same as that of keramamide F (48), the only change being the different stereochemistry at $\mathrm{C}-13$ of the $\alpha$-keto- $\beta$-amino acid (Figure 16 ).

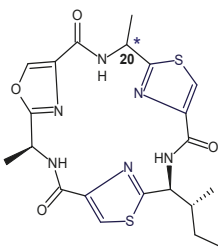

46: ${ }^{*} 20 L$

47: *20D

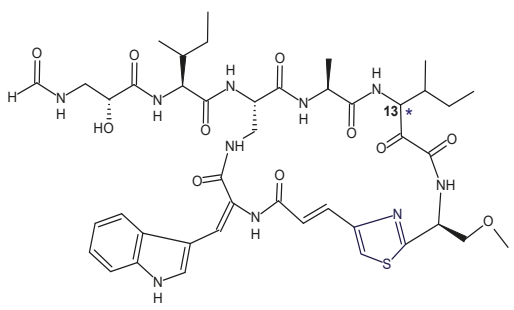

48: ${ }^{*} 13 R$

49: *13S

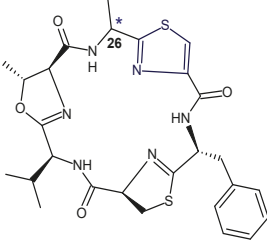

50: $26 D \quad 51:{ }^{*} 26 L$

Figure 16. Structures of bistratamide M (46) with configuration L at C-20, bistratamide N (47) with configuration D at C-20, keramamide F (48) with stereochemistry $R$ at C-13, keramamide G (49) with stereochemistry $S$ at C-13, bistratamide $\mathrm{K}$ (50) with configuration D at C-26, and bistratamide L (51) with configuration $\mathrm{L}$ at $\mathrm{C}-26$.

Grassypeptolides D and E are diasteromeric cyclic peptides from a red sea Leptolyngbya cyanobacterium. These cyclodepsipeptides were found to contain two aromatic residues, phenyllactic acid (Pla), $N$-methylphenylalanine ( $N$-Me-Phe); $\beta$-amino acid residue 2-methyl-3-aminobutyric acid (Maba); and 2-aminobutyric acid (Aba) residue. Further, structural analysis indicated the presence of a 2-methylthiazoline carboxylic acid derived from $\mathrm{N}$-methylphenylalanine ( $\mathrm{N}$-Me-Phe-4-Me-thn-ca) and an Aba-thn-ca unit. Grassypeptolides D and E showed significant cytotoxicity to HeLa ( $\mathrm{IC}_{50}$ : 335 and $192 \mathrm{nM}$ ) and mouse neuro-2a blastoma cells ( $\mathrm{IC}_{50}$ : 599 and $\left.407 \mathrm{nM}\right)$. These depsipeptides were found to be threonine/ $\mathrm{N}$-methylleucine diastereomers and possesssed different configurations for both L-Thr and N-Me-L-Leu in grassypeptolide E (53) relative to grassypeptolide D (52). Grassypeptolide D (7R,11R; D-allo-Thr and N-Me-D-Leu) (52) was found to be approximately 1.5 -fold less cytotoxic to HeLa cervical carcinoma and neuro-2a mouse blastoma cells than grassypeptolide E (7S,11S; L-Thr and $\mathrm{N}$-Me-L-Leu) (53). Moreover, grassypeptolides A and $\mathrm{C}$ were found to be the $\mathrm{N}$-methylphenylalanine epimers with stereochemistry $(7 R, 11 R, 25 R, 29 R)$ and $(7 R, 11 R, 25 R, 29 S)$, respectively. Grassypeptolide $C$ showed 16-23-fold greater potency than grassypeptolide A against colorectal adenocarcinoma HT29 and cervical carcinoma HeLa cells [25] (Figure 17).

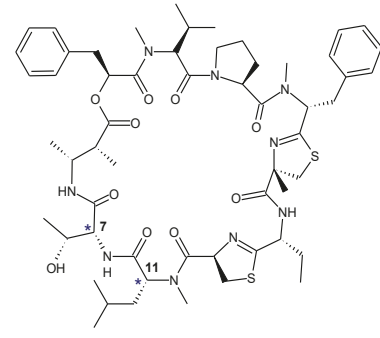

52: ${ }^{*} 7 R, 11 R$

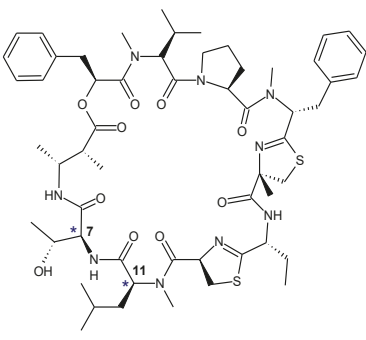

53: *7S,11S

Figure 17. Structures of grassypeptolide D (52) with stereochemistry $R$ at C-7 and C-11 of D-allo-Thr and N-Me-D-Leu residues and grassypeptolide E (53) with stereochemistry $S$ at C-7 and C-11 of L-Thr and $N$-Me-L-Leu residues. 
Nostocyclamide M (54) and tenuecyclamide C (55) were found to be diasteromers. Nostocyclamide $\mathrm{M}$ (54) has the same constitution as tenuecyclamide $C$ (55) but differs in the configuration of methionine in the structure. Adjacent to one of thiazole ring, D-methionine was present in cyclic hexapeptide nostocyclamide M (54) wheresas there was L-methionine in cyclic hexapeptide tenuecyclamide C (55). Nostocyclamide M (54) displayed allelopathic activity like nostocyclamide but was inactive against grazers unlike the latter [36] (Figure 18).

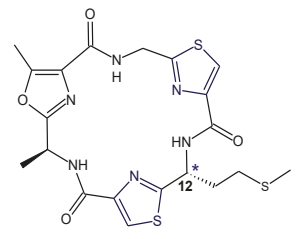

54: *12D

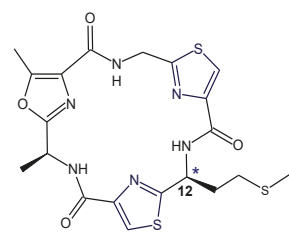

55: ${ }^{*} 12 L$

Figure 18. Structures of nostocyclamide M (54) with Gly-Tzl and Met-Tzl residues, having methionine configuration D at C-12, and tenuecyclamide C (55) with Gly-Tzl and Met-Tzl residues, having methionine configuration $\mathrm{L}$ at $\mathrm{C}-12$.

Ulongamides (1-3) are thiazole-containing cytotoxic cyclic depsipeptides with a novel $\beta$-amino acid, 3-amino-2-methylhexanoic acid (Amha), stereochemistry which differentiates ulongamides A-C from ulongamides D-F. The former has the Amha residue in $2 R, 3 R$ configuration, while the latter contains an Amha unit in 2S,3R configuration. The 2-hydroxy-3-methylpentanoic acid (Hmpa) residue was found to be part of ulongamide E and F (3) structures, and the configuration of the residue was $2 S, 3 S$. Furthermore, stereochemistry of the 2-hdroxyisovaleric acid (Hiva) unit present in ulongamide D (2) was found to be $S$ [13].

Calyxamides A and B $(56,57)$ are cyclic peptides containing 5-hydroxytryptophan (Htrp), isolated from the marine sponge Discodermia calyx. These peptides contained residues like 2,3-diaminopropionic acid (Dpr) in addition to (O-methylseryl)thiazole moiety. Calyxamides A and B $(56,57)$ possessed the same planar structure but are isomeric at the 3-position of the 3-amino-2-keto-4-methylhexanoic acid (AKMH) residue like keramamides F and G (13S and 13R). Structures of calyxamides differ in stereochemistry on isoleucine moiety adjacent to (O-methylseryl)thiazole moiety. Calyxamide B (57) was found to be the diastereomer of calyxamide A (56) and displayed more cytotoxicity against P388 murine leukemia cells, with an $\mathrm{IC}_{50}$ value of $0.9 \mu \mathrm{M}$, in comparison to calyxamide $\mathrm{A}\left(\mathrm{IC}_{50}: 3.9 \mu \mathrm{M}\right)(56)$ [110] (Figure 19).

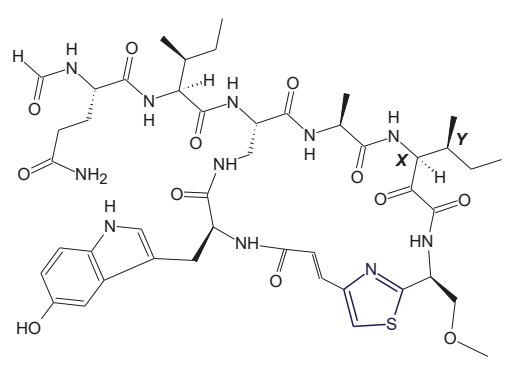

56: $\mathrm{X}=\mathrm{Y}=S$

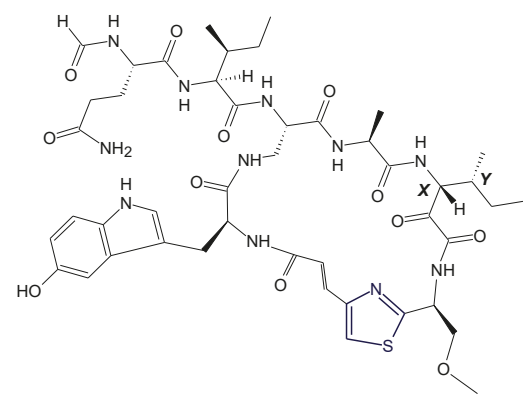

57: $\mathrm{X}=\mathrm{Y}=\mathrm{R}$

Figure 19. Structures of calyxamide A (56) with $O$-Me-Ser-Tzl moiety, having stereochemistry $S$ at the 3-position of 3-amino-2-keto-4-methylhexanoic acid (AKMH) residue, and Calyxamide B (57) with $O$-Me-Ser-Tzl moiety, having stereochemistry $R$ at the 3-position of AKMH residue. 
Aciculitamides $\mathrm{A}$ and $\mathrm{B}$ are bicyclic $E$ and $\mathrm{Z}$ isomeric peptides obtained from the lithistid sponge Aciculites orientalis and result from oxidation of the imidazole ring of aciculitins A-C, bicycles containing an unusual histidino-tyrosine bridge. Aciculitamide A did not show any cytotoxicity against HCT-116 and/or antifungal activity [118].

Sclerotides A and B are cyclopolypeptides from marine-derived fungus, Aspergillus sclerotiorum PT06-1. These cyclic hexapeptides contained amino acid residues like L-threonine, L-alanine, phenylalanine, serine, anthranilic acid (AA), and dehydrotryptophan ( $\Delta$-Trp). Sclerotides A and $B$ were found to be $Z$ and $E$ isomers and differed in stereochemistry of dehydrotryptophan. Sclerotide $B$ showed more antifungal activity against Candida albicans with MIC values of $3.5 \mu \mathrm{M}$ in comparison to sclerotide A (MIC: $7 \mu \mathrm{M}$ ). In addition, sclerotide B exhibited weak cytotoxic activity against the HL-60 cell line $\left(\mathrm{IC}_{50}: 56.1 \mu \mathrm{M}\right)$ and selective antibacterial activity against Pseudomonas aeruginosa (MIC: $35.3 \mu \mathrm{M}$ ) [131].

\section{Synthesis of Heterocyclic Peptides}

Despite of lot of challenges associated with synthesizing complex peptide molecules [132-135], syntheses of diverse aromatic/heteroaromatic peptides were accomplished by several research groups employing diverse techniques of peptide synthesis including solid-phase peptide synthesis (SPPS), liquid-phase peptide synthesis (LPPS), and a mixed solid-phase/solution synthesis strategy, irrespective of whether these congeners belong to linear analogues [136-151] or are cyclic in nature [152-169]. Literature is enriched with reports involving synthesis of various heterocyclic cyclopolypeptides bearing thiazole/thiazoline/tryptophan/histidine moieties viz. cyclodidemnamide B [42], dolastatin 3 [90], aeruginazole A [170], didmolamide B (29) [171], dolastatin 10 (20) [172], scleritodermin A (10) [173], obyanamide (8) [174,175], marthiapeptide A [176], diandrine C [177], diandrine A [178], sarcodactylamide [179], segetalin C [180], segetalin E [181], annomuricatin B [182], and gypsin D [183].

The first total synthesis of thiazole and methyloxazoline-containing cyclohexapeptides didmolamides $\mathrm{A}$ and $\mathrm{B}$ was accomplished by the solid phase assembly of thiazole-containing amino acids and Fmoc-protected $\alpha$-amino acids. The synthesis of thiazole-containing didmolamide B (29) was also achieved using solution phase peptide synthesis. The crucial thiazole amino acid was synthesized by $\mathrm{MnO}_{2}$ oxidation of a thiazoline prepared from an Ala-Cys dipeptide using bis(triphenyl)oxodiphosphonium trifluoromethanesulfonate. The final macrolactamization was accomplished efficiently by benzotriazole-1-yl-oxy-tris-pyrrolidino-phosphonium hexafluorophosphate (PyBOP) and 4-dimethylaminopyridine (DMAP) [171].

A practical approach to asymmetric synthesis of dolastatin 10 (20) was found to involve SmI2-induced cross-coupling and asymmetric addition of chiral N-sulfinyl imine [172].

The synthesis of the C1-N15 fragment of the marine natural product scleritodermin A (10) was accomplished through a short and stereocontrolled sequence. The highlights of this route included synthesis of a novel conjugated thiazole moiety 2-(1-amino-2-p-hydroxyphenylethane)-4(4-carboxy-2,4-dimethyl-2Z,4E-propadiene)-thiazole (ACT) fragment and the formation of the $\alpha$-keto amide linkage by the use of a highly activated $\alpha, \beta$-ketonitrile [173]. The total synthesis of a cytotoxic $N$-methylated thiazole-containing cyclic depsipeptide obyanamide (8) was accomplished that included the preparation of two protected fragments before macrocyclization, starting from material (S)-2-aminobutyric acid. The synthesis has led to a reassignment of the C-3 configuration in $\beta$-amino acid residue. As a result, the configuration at $C-3$ position has been amended as $R[174,175]$.

The cytotoxic polythiazole-containing cyclopeptide marthiapeptide A having a linked trithiazole-thiazoline system was synthesized via two routes. The initial strategy involved a macrocyclization of the linear precursor via a peptide-coupling reaction between the amine on the alanine residue and the carboxylic acid end of isoleucine. However, the cyclization was not successful, which was attributed to the closing point being too close to the rigid heterocyclic thiazole moiety. The second strategy involved closing between the thiazoline and peptide in which successful 
cyclization can be attributed to the flexibility of the thiazoline, which allows a connection between the molecule's head and tail [176].

\section{Structural Activity Relationships}

Structural activity relationships (SAR) are prime keys to diverse aspects of drug discovery, ranging from primary screening to extensive lead optimization. SAR can be used to predict bioactivity from the molecular structure. This powerful technology is used in drug discovery to guide the acquisition or synthesis of desirable new compounds as well as to further characterize existing molecules. The principle of structure-activity relationship indicated that there is a relationship between molecular structures and their biological activity and solely depends on the recognition of which structural characteristics correlate with chemical and biological reactivity.

The lissoclinamides, heterocyclic peptides isolated from sea squirt Lissoclinum patella, are derived from a cyclic heptapeptide in which a threonine has been cyclised to an oxazoline and two cysteines have been cyclised to give a thiazole or thiazoline. While comparing natural and synthetic lissoclinamides, it was found that the replacement of thiazoline rings with oxazolines decreased activity to a greater extent than replacement of oxazoline rings with thiazolines [184]. This study further showed that it was not the individual components of the macrocycle that conferred high activity, but rather, the overall conformation of this molecule was responsible for the bioactivity. While comparing structures of lissoclinamides 4 and 5, it was observed that these compounds differ only in the oxidation state of a single thiazole unit but that this difference makes lissoclinamide 5 two orders of magnitude less cytotoxic than lissoclinamide 4 against bladder carcinoma (T24) cells [55].

In raocyclamides $(42,43)$, the presence of oxazoline moiety was found to be essential for cytotoxicity against sea urchin embryos. The cyanobacterium-derived cyclopolypeptides raocyclamide A and B $(42,43)$ possessed thiazole and oxazoline rings in their composition, but raocyclamide A (42) contained an additional oxazoline moiety in its structure. This structural change results in a lot of variation in the biological response. While comparing the bioeffects of these cyclopolypeptides, it was found that raocyclamide A (42) inhibited the division of embryos of Paracentrotus lividus with an effective dose for $100 \%$ inhibition $\left(\mathrm{ED}_{100}\right)$ of $30 \mu \mathrm{g} / \mathrm{mL}$, whereas raocyclamide $\mathrm{B}(43)$ was inactive even at the concentrations of $250 \mu \mathrm{g} / \mathrm{mL}$ [32].

Replacement of $\mathrm{D}$-valine moiety with $\mathrm{D}$-methionine adjacent to one of the thiazole rings in the structure of macrocyclic thiazole and methyloxazole-containing allelochemical nostocyclamide resulted in cyanobacterial cyclopeptide nostocyclamide M (54) with inactivity toward grazers, but this structural modification does not affect the allelopathic activity against anabaena 7120 [36].

The reduction of isoleucylthiazole (Ile-Tzl) residue of a thiazole- and methyloxazoline-containing cyclooligopeptide of cyanobacterial origin, aerucyclamide B, to an isoleucylthiazoline (Ile-Tzn) residue resulted in a close analogue aerucyclamide A. From this one structural modification, the antiplasmodial activity was found to decrease by 1 order of magnitude. Further, the cyclohexapeptide aerucyclamide C underwent hydrolysis reaction using trifluoroacetic acid to form ring-opened products microcyclamide 7806A and microcyclamide 7806B. This change in structure from rigid, disk-like cyclamides to methyloxazoline ( $\mathrm{mOzn}$ ) ring-opened hydrolysis products resulted in loss of antimicrobial and cytotoxic activities [38]. In comparison, aerucyclamide B was the most active antiplasmodial compound among aerucyclamides against chloroquine-resistant strain $\mathrm{K} 1$ of $P$. falciparum, with selectivity against a rat myoblast cell line, whereas against parasite T. brucei rhodesiense, the most active compound was aerucyclamide $\mathrm{C}$.

The cyclic structure of oxazole-rich, thiazole-containing polypeptide mechercharmycin A was found to be essential for its strong antitumor activity against human lung cancer and leukemia cells. The cyclic ring opening of mechercharmycin A resulted in linear peptide mechercharmycin B which did not displayed any inhibitory activity toward any of the cell lines [79].

The ascidian-derived cytotoxic cyclic hexapeptides, bistratamides A and B, differed from each other only by the presence or absence of one double bond. The conversion of one thiazoline in 
bistratamide $\mathrm{A}$ to a thiazole in bistratamide B, i.e., oxidation of thiazoline to thiazole, resulted in a less toxic compound. For example, comparing bioactivities of bistratamides A and B, the former has an $\mathrm{IC}_{50}$ value of about $50 \mu \mathrm{g} / \mathrm{mL}$ and latter has an $\mathrm{IC}_{50}$ value greater than $100 \mu \mathrm{g} / \mathrm{mL}$ against human cell lines including fibroblasts and bladder carcinoma cells [60].

Replacement of the alanine unit adjacent to the thiazole ring by a threonine unit in cyanobacterium-derived modified cyclohexapeptide venturamide A (31) resulted in a related cyclic hexapeptide venturamide B (32). This structural change reflected an increase in antimalarial activity against Plasmodium falciparum and cytotoxic activity toward mammalian Vero cells. However, with this modification, a decrease in bioactivity against Trypanasoma cruzi and MCF-7 cancer cells was observed [34].

The lyngbyabellin family of thiazole-containing peptolides are known to exhibit moderate to potent cytotoxicity against a number of different cancer cell types through the promotion of actin polymerization. In the HCT116 colon cancer cell line assay, reproducible $\mathrm{IC}_{50}$ values $(40.9 \pm 3.3 \mathrm{nM})$ were obtained for lyngbyabellin $\mathrm{N}$, confirming the potent cytotoxic effect of this new member of the lyngbyabellin class and suggesting that the side chain of lyngbyabellin $\mathrm{N}$ was an essential structural feature for this potent activity. However, this trend was not entirely consistent within this structure class as other lyngbyabellin analogs lacking the side chain were found to exhibit bioactivity against HT29 and HeLa cells [29]. When compared to lyngbyabellin A, lyngbyabellin J displayed slightly less bioactivity against HT29 colorectal adenocarcinoma and HeLa cervical carcinoma cells. The cytoskeletal actin-disrupting lyngbyabellin 27-deoxylyngbyabellin A was found to be more potent than lyngbyabellin A against HT29 and HeLa carcinoma cell lines ( $\mathrm{IC}_{50}$ values: 27-deoxylyngbyabellin A, 0.012 and $0.0073 \mu \mathrm{M}$; lyngbyabellin A, 0.047 and $0.022 \mu \mathrm{M}$ ), indicating the importance of hydroxylation at the C-27 position. However, lyngbyabellin A, its 27-deoxy analog, and lyngbyabellin J exhibited more cytotoxic activity against the two cell lines when compared to peptolide lyngbyabellin $\mathrm{B}\left(\mathrm{IC}_{50}\right.$ values: 1.1 and $\left.0.71 \mu \mathrm{M}\right)$. The configuration of the hydroxy acid-derived unit esterified to the 7,7-dichloro-3-acyloxy-2-methyloctanoic acid residue (here, Dhmpa) was not found to have a profound effect on the activity. Furthermore, close analysis of bioactivity data indicated that the cytotoxicity of cyclic and acyclic lyngbyabellins appeared to be similar [30].

The antithrombin cyclopolypeptides and cyclotheonellazoles had structural features similar to another Theonella sponge-derived peptide oriamide (9) in having nonproteinogenic amino acids like 4-propenoyl-2-tyrosylthiazole and 3-amino-4-methyl-2-oxohexanoic acid and showed potent inhibitory activity against the serine protease enzymes chymotrypsin and elastase. Cyclotheonellazole complexes with elastase/chymotrypsin exhibit a tetrahedral transition state involving the keto group of Amoha and Ser195 of elastase, while the side chain of Amoha fits in the enzyme S1 pocket. Cyclotheonellazole A, which contains a 2-aminopentanoic acid residue, was found to be the most potent inhibitor. This was probably due to a better compatibility with the enzyme S2 subsite. Cyclotheonellazoles B and C contained the amino acids leucine and homoalanine, and it appeared that the length and the branching of the aliphatic chain influenced the bioactivity. Further, these cyclopeptides were inactive against the malaria parasite plasmodium falciparum at $\mathrm{IC}_{50}$ values of greater than $20 \mu \mathrm{g} / \mathrm{mL}$ [68].

Ulongamides (1-3) are cyanobacterium-derived $\beta$-amino acid- and thiazole-containing cyclic peptides with weak cytotoxic properties. In cyclodepsipeptide ulongamide $F(3)$, the lack of an aromatic amino acid or the $\mathrm{N}$-methyl group adjacent to the hydroxyl acid (N-methylphenylalanine/N-methyl tyrosine in ulongapeptides $\mathrm{A}-\mathrm{E}$ and $\mathrm{L}$-valine in ulongapeptide $\mathrm{F}$ ) was found to be detrimental to bioactivity. This was evident from the observation that ulongamide $\mathrm{F}$ (3) was inactive at $<10 \mu \mathrm{M}$ against KB and LoVo cells in comparison to ulongapeptides A (1) and D (2), which displayed cytotoxicity against both cell lines [13].

\section{Biological Activity}

Although thiazole-containing cyclopolypeptides of marine origin are associated with a number of bioactivities including antitubercular, antibacterial, antifungal, and inhibitory activity against serine 
protease enzymes chymotrypsin and elastase; anti-HIV activity; antiproliferative activity; antimalarial activity; and inhibitory activity against the transcription factor activator protein-1, the majority of them were found to exhibit anticancer activity. Various pharmacological activity-associated marine-derived Tzl-containing cyclopolypeptides along with susceptible cell line/organism with minimum inhibitory concentration are tabulated in Table 2.

Table 2. Heterocyclic Tzl-based peptides (TBPs) with diverse pharmacological activities.

\begin{tabular}{|c|c|c|c|}
\hline \multirow{2}{*}{ TBPs } & \multirow{2}{*}{ Resource } & \multicolumn{2}{|l|}{ Bioactivity } \\
\hline & & Susceptibilty & MIC $^{\mathbf{a}}$ Value \\
\hline Haligramide A [63] & $\begin{array}{l}\text { marine sponge } \\
\text { Haliclona nigra }\end{array}$ & $\begin{array}{l}\text { Cytotoxicity against A-549 (lung), } \\
\left.\text { HCT-15 (colon), SF-539 (CNS }{ }^{b}\right) \text {, and SNB-19 } \\
\text { (CNS) human tumor cell lines }\end{array}$ & $\begin{array}{c}5.17-15.62 \\
\mu \mathrm{g} / \mathrm{mL}\end{array}$ \\
\hline Haligramide B [63] & $\begin{array}{l}\text { marine sponge } \\
\text { Haliclona nigra }\end{array}$ & $\begin{array}{l}\text { Cytotoxicity against A-549 (lung), } \\
\text { HCT-15 (colon), SF-539 (CNS), and SNB-19 } \\
\text { (CNS) human tumor cells }\end{array}$ & $3.89-8.82 \mu \mathrm{g} / \mathrm{mL}$ \\
\hline Scleritodermin A [64] & $\begin{array}{l}\text { marine sponge } \\
\text { Scleritoderma nodosum }\end{array}$ & $\begin{array}{l}\text { Cytotoxicity against colon HCT116, ovarian } \\
\text { A2780, and breast SKBR3 cell lines }\end{array}$ & $0.67-1.9 \mu \mathrm{M}$ \\
\hline Obyanamide [12] & $\begin{array}{l}\text { marine cyanobacterium } \\
\text { Lyngbya confervoides }\end{array}$ & Cytotoxicity against $\mathrm{KB}^{\mathrm{C}}$ and LoVo cells & 0.58 and $3.14 \mu \mathrm{g} / \mathrm{mL}$ \\
\hline Waiakeamide [66] & $\begin{array}{l}\text { marine sponge } \\
\text { Ircinia dendroides }\end{array}$ & $\begin{array}{c}\text { Anti-TB activity against Mycobacterium } \\
\text { tuberculosis }\end{array}$ & $7.8 \mu \mathrm{g} / \mathrm{mL}$ \\
\hline Ulongamide A [13] & $\begin{array}{l}\text { marine cyanobacterium } \\
\text { Lyngbya sp. }\end{array}$ & Cytotoxicity against KB and LoVo cells & 1 and $5 \mu \mathrm{M}$ \\
\hline Guineamide B [14] & $\begin{array}{c}\text { marine cyanobacterium } \\
\text { Lyngbya majuscula }\end{array}$ & $\begin{array}{l}\text { Cytotoxicity against mouse neuroblastoma } \\
\text { cell line }\end{array}$ & $15 \mu \mathrm{M}$ \\
\hline Calyxamide A [110] & $\begin{array}{l}\text { marine sponge } \\
\text { Discodermia calyx }\end{array}$ & $\begin{array}{l}\text { Cytotoxicity against P388 murine } \\
\text { leukemia cells }\end{array}$ & 3.9 and $0.9 \mu \mathrm{M}$ \\
\hline Bistratamide J [50] & $\begin{array}{c}\text { marine ascidian } \\
\text { Lissoclinum bistratum }\end{array}$ & $\begin{array}{l}\text { Cytotoxic activity against the human colon } \\
\text { tumor (HCT-116) cell line }\end{array}$ & $1.0 \mu \mathrm{g} / \mathrm{mL}$ \\
\hline $\begin{array}{l}\text { Didmolamide A } \\
\text { and B [48] }\end{array}$ & $\begin{array}{l}\text { marine tunicate } \\
\text { Didemnum molle }\end{array}$ & $\begin{array}{c}\text { Cytotoxicity against several } \\
\text { cultured tumor cell lines (A549, HT29, and } \\
\text { MEL28) }\end{array}$ & $10-20 \mu \mathrm{g} / \mathrm{mL}$ \\
\hline Aeruginazole A [91] & $\begin{array}{l}\text { freshwater } \\
\text { cyanobacterium } \\
\text { Microcystis sp. }\end{array}$ & $\begin{array}{c}\text { Antibacterial activity againt } \\
\text { B. subtilis and S. albus } \\
\text { Cytotoxicity against MOLT-4 human } \\
\text { leukemia cell line and peripheral blood } \\
\text { lymphocytes }\end{array}$ & $\begin{array}{l}2.2 \text { and } 8.7 \mu \mathrm{M} \\
41 \text { and } 22.5 \mu \mathrm{M}\end{array}$ \\
\hline $\begin{array}{l}\text { Cyclotheonellazole A, B } \\
\text { and C [68] }\end{array}$ & $\begin{array}{l}\text { marine sponge } \\
\text { Theonella aff. swinhoei }\end{array}$ & $\begin{array}{c}\text { Inhibitory activity against serine protease } \\
\text { enzyme chymotrypsin } \\
\text { Inhibitory activity against serine protease } \\
\text { enzyme elastase }\end{array}$ & $\begin{array}{c}0.62,2.8 \text {, and } \\
2.3 \mathrm{nM} \\
0.034,0.10 \text {, and } 0.099 \\
\mathrm{nM}\end{array}$ \\
\hline $\begin{array}{c}\text { Microcyclamide MZ602 } \\
{[18]}\end{array}$ & $\begin{array}{l}\text { cyanobacterium } \\
\text { Microcystis sp. }\end{array}$ & $\begin{array}{c}\text { Inhibition activity of } \\
\text { chymotrypsin }\end{array}$ & $75 \mu \mathrm{M}$ \\
\hline Dolastatin 3 [9] & $\begin{array}{l}\text { marine cyanobacterium } \\
\text { Lyngbya majuscula }\end{array}$ & $\begin{array}{c}\text { Inhibition of HIV-1 integrase (for the } \\
\text { terminal-cleavage and strand- } \\
\text { transfer reactions) }\end{array}$ & $\begin{array}{c}5 \mathrm{mM} \\
\text { and } 4.1 \mathrm{mM}\end{array}$ \\
\hline Lyngbyabellin A [27] & $\begin{array}{l}\text { marine cyanobacterium } \\
\text { Lyngbya majuscula }\end{array}$ & $\begin{array}{c}\text { Cytotoxicity against KB cells (human } \\
\text { nasopharyngeal carcinoma cell line) and } \\
\text { LoVo cells (human colon adenocarcinoma } \\
\text { cell line) } \\
\text { Cytotoxicity against HT29 colorectal } \\
\text { adenocarcinoma and HeLa cervical } \\
\text { carcinoma cells } \\
\text { Cytoskeletal-disrupting effects } \\
\text { in A-10 cells } \\
\text { Toxicity to brine shrimp (Artemia salina) }\end{array}$ & $\begin{array}{c}0.03 \text { and } 0.50 \mu \mathrm{g} / \mathrm{mL} \\
1.1 \text { and } 0.71 \mu \mathrm{M} \\
0.01-5.0 \mu \mathrm{g} / \mathrm{mL}\end{array}$ \\
\hline Lyngbyabellin B [86] & $\begin{array}{l}\text { marine cyanobacterium } \\
\text { Lyngbya majuscula }\end{array}$ & $\begin{array}{c}\text { Antifungal activity against Candida albicans } \\
\text { (ATCC 14053) in a disk diffusion assay } \\
\text { Cytotoxicity against HT29 colorectal } \\
\text { adenocarcinoma and HeLa cervical } \\
\text { carcinoma cells }\end{array}$ & $\begin{array}{c}3.0 \mathrm{ppm} \\
100 \mu \mathrm{g} / \mathrm{disk} \\
1.1 \text { and } 0.71 \mu \mathrm{M}\end{array}$ \\
\hline Lyngbyabellin E [28] & $\begin{array}{l}\text { marine cyanobacterium } \\
\text { Lyngbya majuscula }\end{array}$ & $\begin{array}{l}\text { Cytotoxicity against NCI-H460 human lung } \\
\text { tumor and neuro-2a mouse neuroblastoma } \\
\text { cells } \\
\text { Cytoskeletal-disrupting effects in A-10 cells }\end{array}$ & $\begin{array}{c}0.4 \text { and } 1.2 \mu \mathrm{M} \\
0.01-6.0 \mu \mathrm{M}\end{array}$ \\
\hline
\end{tabular}


Table 2. Cont.

\begin{tabular}{|c|c|c|c|}
\hline \multirow{2}{*}{ TBPs } & \multirow{2}{*}{ Resource } & \multicolumn{2}{|l|}{ Bioactivity } \\
\hline & & Susceptibilty & MIC $^{a}$ Value \\
\hline Lyngbyabellin H [28] & $\begin{array}{l}\text { marine cyanobacterium } \\
\text { Lyngbya majuscula }\end{array}$ & $\begin{array}{c}\text { Cytotoxicity against NCI-H460 human lung } \\
\text { tumor and neuro-2a mouse neuroblastoma } \\
\text { cells }\end{array}$ & 0.2 and $1.4 \mu \mathrm{M}$ \\
\hline Lyngbyabellin N [29] & $\begin{array}{l}\text { marine cyanobacterium } \\
\text { Moorea bouilloni }\end{array}$ & $\begin{array}{l}\text { Cytotoxic activity against HCT116 colon } \\
\text { cancer cell line }\end{array}$ & $40.9 \mathrm{nM}$ \\
\hline $\begin{array}{l}\text { 27-Deoxy- } \\
\text { lyngbyabellin A [30] }\end{array}$ & $\begin{array}{l}\text { marine cyanobacterium } \\
\text { Lyngbya bouillonii }\end{array}$ & $\begin{array}{c}\text { Cytotoxicity against HT29 colorectal } \\
\text { adenocarcinoma and HeLa cervical } \\
\text { carcinoma cells }\end{array}$ & 0.012 and $0.0073 \mu \mathrm{M}$ \\
\hline Lyngbyabellin J [30] & $\begin{array}{l}\text { marine cyanobacterium } \\
\text { Lyngbya bouillonii }\end{array}$ & $\begin{array}{c}\text { Cytotoxicity against HT29 colorectal } \\
\text { adenocarcinoma and HeLa cervical } \\
\text { carcinoma cells }\end{array}$ & 0.054 and $0.041 \mu \mathrm{M}$ \\
\hline Raocyclamide A [32] & $\begin{array}{l}\text { filamentous } \\
\text { cyanobacterium } \\
\text { Oscillatoria raoi }\end{array}$ & $\begin{array}{c}\text { Cytotoxicity against embryos of sea urchin } \\
\text { Paracentrotus lividus }\end{array}$ & $30 \mu \mathrm{g} / \mathrm{mL}\left(\mathrm{ED}_{100}\right)^{\mathrm{d}}$ \\
\hline $\begin{array}{l}\text { Tenuecyclamide A, C } \\
\text { and D [105] }\end{array}$ & $\begin{array}{l}\text { cultured cyanobacterium } \\
\text { Nostoc spongiaeforme } \\
\text { var. tenue }\end{array}$ & $\begin{array}{c}\text { Cytotoxicity against embryos of sea urchin } \\
\text { Paracentrotus lividus }\end{array}$ & $\begin{array}{c}10.8,9.0 \text {, and } 19.1 \mu \mathrm{M} \\
\left(\mathrm{ED}_{100}\right)\end{array}$ \\
\hline Dolastatin I [75] & $\begin{array}{c}\text { sea hare } \\
\text { Dolabella auricularia }\end{array}$ & Cytotoxicity against $\mathrm{HeLa} \mathrm{S}_{3}$ cells & $12 \mu \mathrm{g} / \mathrm{mL}$ \\
\hline Marthiapeptide A [74] & $\begin{array}{l}\text { marine actinomycete } \\
\text { Marinactinospora } \\
\text { thermotolerans SCSIO } \\
00652\end{array}$ & $\begin{array}{c}\text { Antibacterial activities against Micrococcus } \\
\text { luteus, Staphylococcus aureus, Bacillus subtilis, } \\
\text { and Bacillus thuringiensis } \\
\text { Cytotoxicity against SF-268 (human } \\
\text { glioblastoma) cell line, MCF-7 (human } \\
\text { breast adenocarcinoma) cell line, NCI-H460 } \\
\text { (human lung carcinoma) cell line, and } \\
\text { HepG2 (human hepatocarcinoma) cancer } \\
\text { cell line }\end{array}$ & $\begin{array}{c}2.0,8.0,4.0 \text {, and } 2.0 \\
\mu \mathrm{g} / \mathrm{mL} \\
0.38,0.43,0.47 \text {, and } \\
0.52 \mu \mathrm{M}\end{array}$ \\
\hline $\begin{array}{l}\text { Keramamide G, H } \\
\text { and J [67] }\end{array}$ & $\begin{array}{l}\text { marine sponge } \\
\text { Theonella } \mathrm{sp} .\end{array}$ & $\begin{array}{c}\text { Cytotoxicity against L1210 murine } \\
\text { leukemia cells and KB human } \\
\text { epidermoid carcinoma cells }\end{array}$ & $10 \mu \mathrm{g} / \mathrm{mL}$ \\
\hline Keramamide K [109] & $\begin{array}{l}\text { marine sponge } \\
\text { Theonella } \mathrm{sp} .\end{array}$ & $\begin{array}{c}\text { Cytotoxicity against L1210 murine } \\
\text { leukemia cells and KB human } \\
\text { epidermoid carcinoma cells }\end{array}$ & 0.72 and $0.42 \mu \mathrm{g} / \mathrm{mL}$ \\
\hline Lissoclinamide 8 [55] & $\begin{array}{c}\text { sea squirt } \\
\text { Lissoclinum patella }\end{array}$ & $\begin{array}{c}\text { Cytotoxicity against T24 (bladder } \\
\text { carcinoma cells), MRC5CV1 (fibroblasts), } \\
\text { and lymphocytes }\end{array}$ & 6,1, and $8 \mu \mathrm{g} / \mathrm{mL}$ \\
\hline Mechercharmycin A [79] & $\begin{array}{l}\text { marine bacterium } \\
\text { Thermoactinomyces sp. } \\
\text { YM3-251 }\end{array}$ & $\begin{array}{c}\text { Cytotoxic activity against A549 (human } \\
\text { lung cancer) cells and Jurkat cells (human } \\
\text { leukemia) }\end{array}$ & $\begin{aligned} & 4.0 \times 10^{-8} \mathrm{M} \text { and } 4.6 \\
& \times 10^{-8} \mathrm{M}\end{aligned}$ \\
\hline Leucamide A [70] & $\begin{array}{l}\text { marine sponge } \\
\text { Leucetta microraphis }\end{array}$ & $\begin{array}{c}\text { Cytotoxicity against HM02, HepG2, and } \\
\text { Huh7 tumor cell lines }\end{array}$ & $5.2,5.9$, and $5.1 \mu \mathrm{g} / \mathrm{mL}$ \\
\hline Bistratamide H [50] & $\begin{array}{c}\text { marine ascidian } \\
\text { Lissoclinum bistratum }\end{array}$ & $\begin{array}{l}\text { Cytotoxic activity against the human colon } \\
\text { tumor (HCT-116) cell line }\end{array}$ & $1.7 \mu \mathrm{g} / \mathrm{mL}$ \\
\hline Patellamide E [58] & $\begin{array}{l}\text { marine ascidian } \\
\text { Lissoclinum patella }\end{array}$ & $\begin{array}{l}\text { Cytotoxicity against human colon tumor } \\
\text { cells in vitro }\end{array}$ & $125 \mu \mathrm{g} / \mathrm{mL}$ \\
\hline Microcyclamide [35] & $\begin{array}{l}\text { cultured cyanobacterium } \\
\text { Microcystis aeruginosa }\end{array}$ & $\begin{array}{c}\text { Cytotoxicity against } \\
\text { P388 murine leukemia cells }\end{array}$ & $1.2 \mu \mathrm{g} / \mathrm{mL}$ \\
\hline Dolastatin E [76] & $\begin{array}{c}\text { sea hare } \\
\text { Dolabella auricularia }\end{array}$ & Cytotoxicity against $\mathrm{HeLa}-\mathrm{S}_{3}$ cells & $22-40 \mu \mathrm{g} / \mathrm{mL}$ \\
\hline Aerucyclamide A [38] & $\begin{array}{c}\text { freshwater } \\
\text { cyanobacterium } \\
\text { Microcystis aeruginosa } \\
\text { PCC } 7806\end{array}$ & $\begin{array}{c}\text { Antiparasite activity against Plasmodium } \\
\text { falciparum } \mathrm{K} 1 \text { and Trypanosoma brucei } \\
\text { rhodesiense } \\
\text { STIB } 900\end{array}$ & 5.0 and $56.3 \mu \mathrm{M}$ \\
\hline Aerucyclamide B [38] & $\begin{array}{c}\text { freshwater } \\
\text { cyanobacterium } \\
\text { Microcystis aeruginosa } \\
\text { PCC } 7806\end{array}$ & $\begin{array}{c}\text { Antiparasite activity against Plasmodium } \\
\text { falciparum } \mathrm{K} 1 \text { and Trypanosoma brucei } \\
\text { rhodesiense } \\
\text { STIB } 900\end{array}$ & 0.7 and $15.9 \mu \mathrm{M}$ \\
\hline Aerucyclamide C [38] & $\begin{array}{c}\text { freshwater } \\
\text { cyanobacterium } \\
\text { Microcystis aeruginosa } \\
\text { PCC } 7806\end{array}$ & $\begin{array}{c}\text { Antiparasite activity against Plasmodium } \\
\text { falciparum } \mathrm{K} 1 \text { and Trypanosoma brucei } \\
\text { rhodesiense STIB } 900\end{array}$ & 2.3 and $9.2 \mu \mathrm{M}$ \\
\hline Aerucyclamide D [38] & $\begin{array}{c}\text { freshwater } \\
\text { cyanobacterium } \\
\text { Microcystis aeruginosa } \\
\text { PCC } 7806\end{array}$ & $\begin{array}{l}\text { Antiparasite activity against Plasmodium } \\
\text { falciparum } \mathrm{K} 1 \text { and Trypanosoma brucei } \\
\text { rhodesiense STIB } 900\end{array}$ & 6.3 and $50.1 \mu \mathrm{M}$ \\
\hline
\end{tabular}


Table 2. Cont.

\begin{tabular}{|c|c|c|c|}
\hline \multirow{2}{*}{ TBPs } & \multirow{2}{*}{ Resource } & \multicolumn{2}{|l|}{ Bioactivity } \\
\hline & & Susceptibilty & MIC $^{a}$ Value \\
\hline $\begin{array}{c}\text { Aerucyclamide A, B and } \\
\text { C }[37,38]\end{array}$ & $\begin{array}{c}\text { freshwater } \\
\text { cyanobacterium } \\
\text { Microcystis aeruginosa } \\
\text { PCC } 7806\end{array}$ & $\begin{array}{l}\text { Grazer toxicity } \\
\text { against the freshwater crustacean } \\
\text { Thamnocephalus platyurus }\end{array}$ & $\begin{array}{c}\text { 30.5, 33.8, and } 70.5 \\
\mu \mathrm{M}\end{array}$ \\
\hline $\begin{array}{l}\text { Aerucyclamide B and C } \\
\text { [38] }\end{array}$ & $\begin{array}{c}\text { freshwater } \\
\text { cyanobacterium } \\
\text { Microcystis aeruginosa } \\
\text { PCC } 7806\end{array}$ & $\begin{array}{l}\text { Cytotoxic activity against Rat } \\
\text { Myoblast L6 cells }\end{array}$ & 120 and $106 \mu \mathrm{M}$ \\
\hline Urukthapelstatin A [78] & $\begin{array}{l}\text { marine-derived } \\
\text { bacterium } \\
\text { Mechercharimyces } \\
\text { asporophorigenens } \\
\text { YM11-542 }\end{array}$ & $\begin{array}{c}\text { Cytotoxicity against A549 human lung } \\
\text { cancer cells }\end{array}$ & $12 \mathrm{nM}$ \\
\hline Mechercharmycin A [79] & $\begin{array}{c}\text { marine-derived } \\
\text { bacterium } \\
\text { Thermoactinomyces sp. }\end{array}$ & $\begin{array}{l}\text { Cytotoxicity against A549 human lung } \\
\text { cancer cells and Jurkat cells }\end{array}$ & $\begin{array}{c}4.0 \times 10^{-8} \mathrm{M} \text { and } 4.6 \times \\
10^{-8} \mathrm{M}\end{array}$ \\
\hline $\begin{array}{c}\text { Ulithiacyclamide } \\
\quad[56,117]\end{array}$ & $\begin{array}{l}\text { marine tunicate } \\
\text { Lissoclinum patella }\end{array}$ & $\begin{array}{l}\text { Cytotoxic activity against L1210, } \\
\text { MRC5CV1, T24, and CEM cell lines } \\
\text { (continuous exposure) }\end{array}$ & $\begin{array}{l}0.35,0.04,0.10, \text { and } \\
0.01 \mu \mathrm{g} / \mathrm{mL}\end{array}$ \\
\hline Ulicyclamide [117] & $\begin{array}{l}\text { marine tunicate } \\
\text { Lissoclinum patella }\end{array}$ & $\begin{array}{l}\text { Cytotoxic activity against L1210 murine } \\
\text { leukemia cells }\end{array}$ & $7.2 \mu \mathrm{g} / \mathrm{mL}$ \\
\hline Patellamide A [117] & $\begin{array}{l}\text { marine tunicate } \\
\text { Lissoclinum patella }\end{array}$ & $\begin{array}{l}\text { Cytotoxic activity against L1210 murine } \\
\text { leukemia and human ALL cell line (CEM) }\end{array}$ & 3.9 and $0.028 \mu \mathrm{g} / \mathrm{mL}$ \\
\hline Patellamide B, C [117] & $\begin{array}{l}\text { marine tunicate } \\
\text { Lissoclinum patella }\end{array}$ & $\begin{array}{l}\text { Cytotoxic activity against L1210 murine } \\
\text { leukemia cells }\end{array}$ & 2.0 and $3.2 \mu \mathrm{g} / \mathrm{mL}$ \\
\hline Venturamide A [34] & $\begin{array}{l}\text { marine } \\
\text { cyanobacterium } \\
\text { Oscillatoria sp. }\end{array}$ & $\begin{array}{l}\text { Antiparasitic activity against Plasmodium } \\
\text { falciparum, Trypanasoma cruzi } \\
\text { Cytotoxicity against mammalian Vero cells } \\
\text { and MCF-7 cancer cells }\end{array}$ & $\begin{array}{l}8.2 \text { and } 14.6 \mu \mathrm{M} \\
86 \text { and } 13.1 \mu \mathrm{M}\end{array}$ \\
\hline Venturamide B [34] & $\begin{array}{l}\text { marine } \\
\text { cyanobacterium } \\
\text { Oscillatoria sp. }\end{array}$ & $\begin{array}{l}\text { Antiparasitic activity against Plasmodium } \\
\quad \text { falciparum, Trypanasoma cruzi } \\
\text { Cytotoxicity against mammalian Vero cells }\end{array}$ & $\begin{array}{l}5.2 \text { and } 15.8 \mu \mathrm{M} \\
56 \mu \mathrm{M}\end{array}$ \\
\hline $\begin{array}{l}\text { Bistratamides A and B } \\
{[60]}\end{array}$ & $\begin{array}{l}\text { aplousobranch } \\
\text { ascidian } \\
\text { Lissoclinum bistratum }\end{array}$ & $\begin{array}{l}\text { Cytotoxicity against MRC5CV1 fibroblasts } \\
\text { and T24 bladder carcinoma cells }\end{array}$ & 50 and $100 \mu \mathrm{g} / \mathrm{mL}$ \\
\hline Bistratamide M [61] & $\begin{array}{l}\text { marine ascidian } \\
\text { Lissoclinum bistratum } \\
\text { freshwater }\end{array}$ & $\begin{array}{l}\text { Cytotoxicity against breast, colon, lung, and } \\
\text { pancreas cell lines }\end{array}$ & $18,16,9.1$, and $9.8 \mu \mathrm{M}$ \\
\hline Balgacyclamide A [33] & $\begin{array}{l}\text { cyanobacterium } \\
\text { Microcystis aeruguinosa } \\
\text { EAWAG } 251\end{array}$ & $\begin{array}{l}\text { Antimalarial activity against Plasmodium } \\
\text { falciparum } \mathrm{K} 1\end{array}$ & 9 and $59 \mu \mathrm{M}$ \\
\hline Balgacyclamide B [33] & $\begin{array}{c}\text { freshwater } \\
\text { cyanobacterium } \\
\text { Microcystis aeruguinosa } \\
\text { EAWAG } 251\end{array}$ & $\begin{array}{c}\text { Antiparasitic activity against Trypanosoma } \\
\text { brucei } \\
\text { rhodesiense STIB } 900\end{array}$ & 8.2 and $51 \mu \mathrm{M}$ \\
\hline
\end{tabular}

${ }^{\mathrm{a}}$ MIC-minimum inhibitory concentration, ${ }^{\mathrm{b}} \mathrm{CNS}$ - central nervous system, ${ }^{\mathrm{c}} \mathrm{KB}$ - ubiquitous KERATIN-forming tumor cell subline, ${ }^{\mathrm{d}} \mathrm{ED}_{100}$ - effective dose for $100 \%$ inhibition.

\section{Mechanism of Action}

Heterocyclic thiazole-based peptides act by a variety of mechanisms including inhibiting microtubule assembly/mitosis, arresting nuclear division, inducing tumor cell apoptosis, causing microtubule depolymerization, inhibiting the protein secretory pathway through preventing cotranslational translocation, inducing G1 cell cycle arrest and an apoptotic cascade, inhibiting the phosphorylation of ERK and Akt, disrupting the cellular actin microfilament network, overproducing 1,3- $\beta$-D-glucan, activating the caspase-3 protein expression and decrease in B-cell lymphoma 2 (Bcl-2) levels, inhibiting nuclear factor kappa-light-chain-enhancer of activated B cells (NF-kB) luciferase and nitrite production, etc.

Dolastatin 10 (20) is a pentapeptide with potential antineoplastic activity, derived from marine mollusk Dolabella auricularia. Its mechanism of action involves the inhibition of tubulin polymerization, tubulin-dependent guanosine triphosphate hydrolysis, and nucleotide exchange, and it is a potent noncompetitive inhibitor of vincristine binding to tubulin. Binding to tubulin, dolastatin 10 (20) 
inhibits microtubule assembly, resulting in the formation of tubulin aggregates and inhibition of mitosis. This thiazole-containing linear peptide also induces tumor cell apoptosis through a mechanism involving bcl-2, an oncoprotein that is overexpressed in some cancers. Microtubule inhibitors from several chemical classes can block the growth and development of malarial parasites, reflecting the importance of microtubules in various essential parasite functions. Dolastatin 10 (20) was a more potent inhibitor of P. falciparum than any other microtubule inhibitor like dolastatin 15 . Dolastatin 10 (20) caused arrested nuclear division and apparent disassembly of mitotic microtubular structures in the parasite, indicating that compounds binding in the "Vinca domain" of tubulin can be highly potent antimalarial agents [185].

Symplostatin 1 (21), an analog of dolastatin 10 (20), is a potent antimitotic with antiproliferative effects that act by causing microtubule depolymerization, formation of abnormal mitotic spindles that lead to mitotic arrest, and initiation of apoptosis involving the phosphorylation of the anti-apoptotic protein Bcl-2. Symplostatin 1 (21) inhibited the polymerization of tubulin in vitro, consistent with its mechanism of action in cells and suggesting that tubulin may be its intracellular target. Additionally, symplostatin 1 (21) was found to inhibit the proliferation and migration of endothelial cells, suggesting that it may have antiangiogenic activity [186].

Largazole is a cyclic peptide with thiazole/thiazoline residues, including a number of unusual structural features, including a 3-hydroxy-7-mercaptohept-4-enoic acid unit and a 16-membered macrocyclic cyclodepsipeptide skeleton. Largazole showed potent and highly selective inhibitory activities against class I HDACs (histone deacetylases) and displayed superior anticancer properties. Largazole was found to strongly stimulate histone hyperacetylation in the tumor, showed efficacy in inhibiting tumor growth and induced apoptosis in the tumor. This effect is likely mediated by modulation of levels of cell cycle regulators, by antagonism of the AKT pathway through IRS-1 downregulation, and by reduction of epidermal growth factor receptor levels [187].

Lyngbyabellins are hectochlorin-related peptides with thiazole moieties that are associated with actin polymerization activity. These lipopeptides were found to induce perceptible thickening of the cytoskeletal elements with a relatable increase in binucleated cells. Lyngbyabellin A was found to disrupt the cellular actin microfilament network in A10 and, accordingly, disrupted cytokinesis in colon carcinoma cells, causing the formation of apoptotic bodies. Lyngbyabellin E exhibited actin polymerization ability and was found to completely block the cellular microfilaments, forming binucleated cells [188].

Scleritodermin A (10) is a cytotoxic cyclic peptide with an unusual $\mathrm{N}$-sulfated side chain and a novel conjugated thiazole moiety as well as an $\alpha$-ketoamide group. Scleritodermin A (10) has significant in vitro cytotoxicity against a panel of human tumor cells lines, and this depsipeptide acts through inhibition of tubulin polymerization and the resulting disruption of microtubules, which is the target of a number of clinically useful natural product anticancer drugs [64].

Theonellamides are sponge-derived antifungal and cytotoxic bicyclic dodecapeptides with a histidine-alanine bridge. Specific binding of these peptides to $3 \beta$-hydroxysterols resulted in overproduction of 1,3- $\beta$-D-glucan and membrane damage in yeasts. The inclusion of cholesterol or ergosterol in phosphatidylcholine membranes significantly enhanced the membrane affinity of theonellamide A because of its direct interaction with $3 \beta$-hydroxyl groups of sterols. Membrane action of theonellamide A proceeds via binding to the membrane surface through direct interaction with sterols and modification of the local membrane curvature in a concentration-dependent manner, resulting in dramatic membrane morphological changes and membrane disruption. Theonellamides represents a new class of sterol-binding molecules that induce membrane damage and activate Rho1-mediated 1,3-beta-D-glucan synthesis [189].

Phalloidin is a tryptophan containing bicyclic phallotoxin, which functions by binding and stabilizing filamentous actin (F-actin) and effectively prevents the depolymerization of actin fibers. Due to its tight and selective binding to F-actin, derivatives of phalloidin-containing fluorescent tags are used widely in microscopy to visualize F-actin in biomedical research. Though phallotoxins are 
highly toxic to liver cells, they add little to the toxicity of ingested death cap, as they are not absorbed through the gut [190].

Jaspamide (Jasplakinolide) is a cytotoxic cyclodepsipeptide with bromotryptophan moiety that induces apoptosis in human leukemia cell lines and brain tumor Jurkat $\mathrm{T}$ cels by activation of caspase- 3 protein expression and decrease in Bcl-2 levels. Apoptosis induced by Jaspamide was associated with caspase-3 activation, decreased Bcl-2 protein expression, and increased Bax levels, suggesting that jaspamide induced a caspase-independent cell death pathway for cytosolic and membrane changes in apoptosis cells and a caspase-dependent cell death pathway for poly (ADP-ribose) polymerase (PARP) protein degradation [191].

Azonazine is a unique peptide with a macrocyclic heterocyclic core of the benzofuro indole ring system with diketopiperazine residue. This hexacyclic dipeptide displayed anti-inflammatory activity and was found to act by inhibiting NF- $\mathrm{kB}$ luciferase and nitrite production [192].

\section{Issues Associated with Marine Peptides in Drug Development}

Marine peptides are fascinating therapeutic candidates due to their diverse bioactivities. They demonstrate significant chemical and biological diversity for drug development including minimized drug-drug interaction, less tissue accumulation, and low toxicity. Approximately $40 \%$ of existing small molecules and $70 \%$ of new candidates under development pipelines suffer from the low solubility problem, which is a major reason for their suboptimal drug delivery as well as failures in their development process. Approaches such as cyclodextrin complexation and solid dispersions have been employed to address this challenge and recommend the better formulation over their existing dosage forms [193-198]. Likewise, peptides, being biomacromolecules, also exhibit various challenges such as limited water solubility, stability aspects, as well as structural and synthesis complexities, limiting their full exploitation in drug development $[199,200]$. Table 3 portrays various issues associated with peptide drug development. Amidst the major challenges, difficulty in optimization of the required peptide length to achieve pharmacologically useful levels for receptor activation accounts for the hindered drug development of marine-based peptides. The optimization depends on variables including the size, accessibility, and fit of ligand-binding surfaces, ligand stability, and receptor residency time. Further, the high proteolytic instability of peptide-based therapeutics can be conquered by alteration of the side chains and amide bonds, which in turn makes the peptide resistant to proteolytic degradation [201]. The challenges of low bioavailability and short half-life can be overpowered by three approaches: (i) modification of the peptide backbone through the introduction of D-amino acids or unnatural amino acids, (ii) alteration of the peptide bonds with reduced amide bonds or $\beta$-amino acids, and (iii) attachment of a fatty acid. Approaches (i) and (ii) drive the peptide backbone through introducing cyclization, reduced flexibility, and enzyme digestion. Approach (iii) could lead to more specific binding to the target leading to enhanced half-life and bioavailability with fewer side effects [202]. Intracellular delivery of peptides has been a subject of interest due to their membrane-binding ability to exert action on the cell surface. Also, involving the protein transduction domain allows intracellular peptide delivery. Although the liposomal and nanoparticle drug delivery takes advantage of fusing the peptides for intracellular drug delivery, they also face the problem of low encapsulation efficiency [202]. During the process development of peptide synthesis, it is difficult to identify the critical process parameters to achieve expected purity and yield. In addition, the peptide synthesis process also depends on the specifications or requirements and targeted volumes. However, the establishment of acceptable standards and proven ranges may be lacking, which in turn accelerates their manufacturing costs during drug development. 
Table 3. Issues associated with marine peptide drug development.

\begin{tabular}{cr}
\hline Sr. No. & Associated Issue \\
\hline 1. & Low bioavailability and short half-life due to instability of peptides in the body \\
2. & Formulation challenges and synthesis challenges including aggregation and solubility problems \\
3. & Difficulty optimizing peptide length to pharmacologically useful levels for receptor activation \\
4. & Expensive synthesis and manufacturing cost \\
5. & Difficulty in delivering expected purities and yields \\
\hline
\end{tabular}

\section{Peptide Market and Clinical Trials}

As a class of drugs, peptides are increasingly important in medicine. The Food and Drug Administration (FDA) has seen a rapid increase in the number of new drug applications submitted for peptide drug products. The availability of generic versions of these products will be critical to increasing public access to these important medications. However, ensuring the quality and equivalence between generic and brand-name peptide drug products raises a number of challenges, and those challenges differ according to the type of peptide drug. For peptide drug products with a specifically defined sequence of amino acids, the challenge has been with impurities that may be inadvertently introduced during the production process that may affect a proposed generic drug's safety profile. Peptide-related impurities can be especially difficult to detect, analyze, and control because they usually have similar sequences to the drug itself. As per the current calculations, the market for peptide and protein drugs is estimated around $10 \%$ of the entire pharmaceutical market and will make up an even larger proportion of the market in the future. Since the early 1980s, more than 200 therapeutic proteins and peptides are approved for clinical use by the US-FDA [203].

Promising preclinical data led to clinical evaluation of a thiazole-containing linear pentapeptide, dolastatin 10 (20), isolated from sea hare as well as cyanobacterium. The potent antimitotic compound, dolastatin 10 (20), was evaluated in many phase I and phase II clinical trials for solid tumor, including a multi-institutional phase II clinical trial for soft tissue sarcoma treatment [204]. Dolastatin 10 (20) was withdrawn from clinical trials due to adverse effects such as peripheral neurophathy in cancer patients. Dolastatin 10 (20) was not found to be successful in human clinical trials, but it acted as a valuable source for a number of related compounds with clinical significance like ILX651, LU103793, and soblidotin $[205,206]$. Chemical modification efforts to reduce toxicity resulted in the synthesis of TZT-1027 (soblidotin or auristatin PE), a microtubule-disrupting compound, which entered a phase II clinical trial in patients with advanced or metastatic soft tissue sarcomas and lung cancer. Soblidotin has not progressed further beyond phase II clinical trials due to the associated hematological toxicities [207].

Although due to poor water solubility dolastatin 15 could not enter clinical trials, the investigations on this linear depsipeptide encouraged the development of its synthetic analogs like synthadotin and cematodin which have entered clinical trials. Preclinical studies confirmed the antitumor potential of the orally active microtubule inhibitor synthadotin against padiatric sarcomas. This depsipeptide has completed three phase II trials for the treatment of hormone refractory prostate cancer and metastatic melanoma that indicated toward the favorable toxicity profiles of synthadotin [208]. Another synthetic analog of dolastatin 15, cemadotin, underwent many phase I and phase II clinical trials against metastatic breast cancer and malignant melanoma. However, clinical trials were discontinued because of inconsiderable cytotoxicity caused by cemadotin in phase II trials and to acute myocardial infarction and neutropenia in phase I clinical trials [209].

Further modifications of soblidotin/auristatin E led to the development of monomethyl auristatin E (MMAE) and monomethyl auristatin F (MMAF), each of which included a secondary amine at their $\mathrm{N}$-terminus. MMAE and MMAF have been used as warheads to link monoclonal antibodies and are presently in many clinical trials for the treatment of cancer, and eventually various antibody-drug conjugates received FDA approval [210,211]. 


\section{Conclusions and Future Prospects}

In present times, there is an increased frequency of resistance for conventional drugs. This fact necessitates the focus of drug research to be shifted toward a new era where bioactive compounds are developed with novel mechanisms of action. TBPs with unique structural features claim their candidature to overcome the existing issues. Various bioactive heteroaromatic peptides have been isolated from different organisms ranging from marine sponges, mollusks, and tunicates to terrestrial cyanobacteria and other microbes including fungi and bacteria. On this basis, various mimetics of bioactive peptides have been synthesized using solid and solution phase techniques of peptide synthesis. Despite enormous potential, utilization of these bioactive peptides is limited due to their stability and bioavailability issues. This review portrays recent updates and future perspectives of TBPs to attract the attention of researchers and scientists leading the efforts toward their clinical translation from the bench to the bedside.

Author Contributions: R.D., S.D., N.K.F., J.S. and R.M. conceived and designed the structure of the review. R.D., S.D., S.V.C., A.S., H.G. and A.A. conducted literature research and drafted the entire manuscript. S.D., S.M., S.S., S.F. and S.J. edited the manuscript. R.D., S.D., S.K., G.J., A.K., N.K.F., S.F., S.J. and S.K.K. supervised and contributed to the key parts of the text associated with it. All authors have read and agreed to the published version of the manuscript.

Funding: This work was partially funded by the Campus Research and Publication Fund Committee of The University of the West Indies, St. Augustine, Trinidad \& Tobago.

Acknowledgments: The authors wish to thank chief librarians of Faculty of Medical Sciences, The University of the West Indies, St. Augustine, Trinidad \& Tobago, WI and University of Puerto Rico, San Juan, PR, USA for providing literature support.

Conflicts of Interest: The authors declare no conflict of interest.

\section{References}

1. Gomtsyan, A. Heterocycles in drugs and drug discovery. Chem. Heterocyl. Compd. 2012, 48, 7-10. [CrossRef]

2. Kumawat, M.K. Thiazole containing heterocycles with antimalarial activity. Curr. Drug Discov. Technol. 2018, 15, 196-200. [CrossRef] [PubMed]

3. Pathak, D.; Dahiya, R.; Pathak, K.; Dahiya, S. New generation antipsychotics: A review. Indian. J. Pharm. Educ. Res. 2006, 40, 77-83.

4. Fang, W.Y.; Dahiya, R.; Qin, H.L.; Mourya, R.; Maharaj, S. Natural proline-rich cyclopolypeptides from marine organisms: Chemistry, synthetic methodologies and biological status. Mar. Drugs 2016, 14, 194. [CrossRef]

5. Dahiya, R.; Pathak, D. Cyclic peptides: New hope for antifungal therapy. Egypt. Pharm. J. 2006, 5, 189-199.

6. Tiwari, J.; Gupta, G.; Dahiya, R.; Pabreja, K.; Kumar Sharma, R.; Mishra, A.; Dua, K. Recent update on biological activities and pharmacological actions of liraglutide. Excli J. 2017, 16, 742-747.

7. Singh, Y.; Gupta, G.; Shrivastava, B.; Dahiya, R.; Tiwari, J.; Ashwathanarayana, M.; Sharma, R.K.; Agrawal, M.; Mishra, A.; Dua, K. Calcitonin gene-related peptide (CGRP): A novel target for Alzheimer's disease. CNS Neurosci. Ther. 2017, 23, 457-461. [CrossRef]

8. Adiv, S.; Ahronov-Nadborny, R.; Carmeli, S. New aeruginazoles, a group of thiazole-containing cyclic peptides from Microcystis aeruginosa blooms. Tetrahedron 2012, 68, 1376-1383. [CrossRef]

9. Mitchell, S.S.; Faulkner, D.J.; Rubins, K.; Bushman, F.D. Dolastatin 3 and two novel cyclic peptides from a Palauan collection of Lyngbya majuscula. J. Nat. Prod. 2000, 63, 279-282. [CrossRef]

10. McIntosh, J.A.; Lin, Z.; Tianero, M.D.; Schmidt, E.W. Aestuaramides, a natural library of cyanobactin cyclic peptides resulting from isoprene-derived Claisen rearrangements. ACS Chem. Biol. 2013, 8, 877-883. [CrossRef]

11. Ploutno, A.; Carmeli, S. Modified peptides from a water bloom of the cyanobacterium Nostoc sp. Tetrahedron 2002, 58, 9949-9957. [CrossRef]

12. Williams, P.G.; Yoshida, W.Y.; Moore, R.E.; Paul, V.J. Isolation and structure determination of obyanamide, a novel cytotoxic cyclic depsipeptide from the marine cyanobacterium Lyngbya confervoides. J. Nat. Prod. 2002, 65, 29-31. [CrossRef] [PubMed] 
13. Luesch, H.; Williams, P.G.; Yoshida, W.Y.; Moore, R.E.; Paul, V.J. Ulongamides A-F, new beta-amino acid-containing cyclodepsipeptides from Palauan collections of the marine cyanobacterium Lyngbya sp. J. Nat. Prod. 2002, 65, 996-1000. [CrossRef] [PubMed]

14. Tan, L.T.; Sitachitta, N.; Gerwick, W.H. The guineamides, novel cyclic depsipeptides from a Papua New Guinea collection of the marine cyanobacterium Lyngbya majuscula. J. Nat. Prod. 2003, 66, 764-771. [CrossRef] [PubMed]

15. Luesch, H.; Yoshida, W.Y.; Moore, R.E.; Paul, V.J. New apratoxins of marine cyanobacterial origin from Guam and Palau. Bioorg. Med. Chem. 2002, 10, 1973-1978. [CrossRef]

16. Hong, J.; Luesch, H. Largazole: From discovery to broad-spectrum therapy. Nat. Prod. Rep. 2012, 29, 449-456. [CrossRef] [PubMed]

17. Sudek, S.; Haygood, M.G.; Youssef, D.T.A.; Schmidt, E.W. Structure of Trichamide, a cyclic peptide from the bloom-forming cyanobacterium Trichodesmium erythraeum, predicted from the genome sequence. Appl. Environ. Microbiol. 2006, 72, 4382-4387. [CrossRef]

18. Zafrir-Ilan, E.; Carmeli, S. Two new microcyclamides from a water bloom of the cyanobacterium Microcystis sp. Tetrahedron Lett. 2010, 51, 6602-6604. [CrossRef]

19. Luesch, H.; Yoshida, W.Y.; Moore, R.E.; Paul, V.J.; Corbett, T.H. Total structure determination of apratoxin A, a potent novel cytotoxin from the marine cyanobacterium Lyngbya majuscula. J. Am. Chem. Soc. 2001, 123, 5418-5423. [CrossRef]

20. Gutiérrez, M.; Suyama, T.L.; Engene, N.; Wingerd, J.S.; Matainaho, T.; Gerwick, W.H. Apratoxin D, a potent cytotoxic cyclodepsipeptide from papua new guinea collections of the marine cyanobacteria Lyngbya majuscule and Lyngbya sordida. J. Nat. Prod. 2008, 71, 1099-1103. [CrossRef]

21. Matthew, S.; Schupp, P.J.; Luesch, H. Apratoxin E, a cytotoxic peptolide from a Guamanian collection of the marine cyanobacterium Lyngbya bouillonii. J. Nat. Prod. 2008, 71, 1113-1116. [CrossRef]

22. Tidgewell, K.; Engene, N.; Byrum, T.; Media, J.; Doi, T.; Valeriote, F.A.; Gerwick, W.H. Evolved diversification of a modular natural product pathway: Apratoxins F and G, two cytotoxic cyclic depsipeptides from a Palmyra collection of Lyngbya bouillonii. ChemBioChem 2010, 11, 1458-1466. [CrossRef] [PubMed]

23. Thornburg, C.C.; Cowley, E.S.; Sikorska, J.; Shaala, L.A.; Ishmael, J.E.; Youssef, D.T.A.; McPhail, K.L. Apratoxin $\mathrm{H}$ and apratoxin A sulfoxide from the Red sea cyanobacterium Moorea producens. J. Nat. Prod. 2013, 76, 1781-1788. [CrossRef] [PubMed]

24. Kwan, J.C.; Ratnayake, R.; Abboud, K.A.; Paul, V.J.; Luesch, H. Grassypeptolides A-C, cytotoxic bis-thiazoline containing marine cyclodepsipeptides. J. Org. Chem. 2010, 75, 8012-8023. [CrossRef] [PubMed]

25. Thornburg, C.C.; Thimmaiah, M.; Shaala, L.A.; Hau, A.M.; Malmo, J.M.; Ishmael, J.E.; Youssef, D.T.A.; McPhail, K.L. Cyclic depsipeptides, grassypeptolides D, E and Ibu epidemethoxylyngbyastatin 3, from a Red sea Leptolyngbya cyanobacterium. J. Nat. Prod. 2011, 74, 1677-1685. [CrossRef] [PubMed]

26. Popplewell, W.L.; Ratnayake, R.; Wilson, J.A.; Beutler, J.A.; Colburn, N.H.; Henrich, C.J.; McMahon, J.B.; McKee, T.C. Grassypeptolides F and G, cyanobacterial peptides from Lyngbya majuscula. J. Nat. Prod. 2011, 74, 1686-1691. [CrossRef] [PubMed]

27. Luesch, H.; Yoshida, W.Y.; Moore, R.E.; Paul, V.J.; Mooberry, S.L. Isolation, Structure determination, and biological activity of lyngbyabellin A from the marine cyanobacterium Lyngbya majuscula. J. Nat. Prod. 2000, 63, 611-615. [CrossRef]

28. Han, B.; McPhail, K.L.; Gross, H.; Goeger, D.E.; Mooberry, S.L.; Gerwick, W.H. Isolation and structure of five lyngbyabellin derivatives from a Papua New Guinea collection of the marine cyanobacterium Lyngbya majuscula. Tetrahedron 2005, 61, 11723-11729. [CrossRef]

29. Choi, H.; Mevers, E.; Byrum, T.; Valeriote, F.A.; Gerwick, W.H. Lyngbyabellins K-N from two Palmyra Atoll collections of the marine cyanobacterium Moorea bouilloni. Eur. J. Org. Chem. 2012, 2012(27), 5141-5150. [CrossRef]

30. Matthew, S.; Salvador, L.A.; Schupp, P.J.; Paul, V.J.; Luesch, H. Cytotoxic halogenated macrolides and modified peptides from the apratoxin-producing marine cyanobacterium Lyngbya bouillonii from Guam. J. Nat. Prod. 2010, 73, 1544-1552. [CrossRef]

31. Soria-Mercado, I.E.; Pereira, A.; Cao, Z.; Murray, T.F.; Gerwick, W.H. Alotamide A, a novel neuropharmacological agent from the marine cyanobacterium Lyngbya bouillonii. Org. Lett. 2009, 11, 4704-4707. [CrossRef] 
32. Admi, V.; Afek, U.; Carmeli, S. Raocyclamides A and B, novel cyclic hexapeptides isolated from the cyanobacterium Oscillatoria raoi. J. Nat. Prod. 1996, 59, 396-399. [CrossRef]

33. Portmann, C.; Sieber, S.; Wirthensohn, S.; Blom, J.F.; Da Silva, L.; Baudat, E.; Kaiser, M.; Brun, R.; Gademann, K. Balgacyclamides, antiplasmodial heterocyclic peptides from Microcystis aeruguinosa EAWAG 251. J. Nat. Prod. 2014, 77, 557-562. [CrossRef] [PubMed]

34. Linington, R.G.; González, J.; Ureña, L.-D.; Romero, L.I.; Ortega-Barría, E.; Gerwick, W.H. Venturamides A and B: Antimalarial constituents of the Panamanian marine cyanobacterium Oscillatoria sp. J. Nat. Prod. 2007, 70, 397-401. [CrossRef] [PubMed]

35. Ishida, K.; Nakagawa, H.; Murakami, M. Microcyclamide, a cytotoxic cyclic hexapeptide from the cyanobacterium Microcystis aeruginosa. J. Nat. Prod. 2000, 63, 1315-1317. [CrossRef]

36. Jüttner, F.; Todorova, A.K.; Walch, N.; von Philipsborn, W. Nostocyclamide M: A cyanobacterial cyclic peptide with allelopathic activity from Nostoc 31. Phytochemistry 2001, 57, 613-619. [CrossRef]

37. Portmann, C.; Blom, J.F.; Gademann, K.; Jüttner, F. Aerucyclamides A and B: Isolation and synthesis of toxic ribosomal heterocyclic peptides from the cyanobacterium Microcystis aeruginosa PCC 7806. J. Nat. Prod. 2008, 71, 1193-1196. [CrossRef]

38. Portmann, C.; Blom, J.F.; Kaiser, M.; Brun, R.; Jüttner, F.; Gademann, K. Isolation of aerucyclamides C and $\mathrm{D}$ and structure revision of microcyclamide 7806A: Heterocyclic ribosomal peptides from Microcystis aeruginosa PCC 7806 and their antiparasite evaluation. J. Nat. Prod. 2008, 71, 1891-1896. [CrossRef]

39. Chuang, P.-H.; Hsieh, P.-W.; Yang, Y.-L.; Hua, K.-F.; Chang, F.-R.; Shiea, J.; Wu, S.-H.; Wu, Y.-C. Cyclopeptides with anti-inflammatory activity from seeds of Annona montana. J. Nat. Prod. 2008, 71, 1365-1370. [CrossRef]

40. Ogino, J.; Moore, R.E.; Patterson, G.M.L.; Smith, C.D. Dendroamides, new cyclic hexapeptides from a blue-green alga. Multidrug-resistance reversing activity of dendroamide A. J. Nat. Prod. 1996, 59, 581-586. [CrossRef]

41. McDonald, L.A.; Foster, M.P.; Phillips, D.R.; Ireland, C.M.; Lee, A.Y.; Clardy, J. Tawicyclamides A and B, new cyclic peptides from the ascidian Lissoclinum patella: Studies on the solution- and solid-state conformations. J. Org. Chem. 1992, 57, 4616-4624. [CrossRef]

42. Arrault, A.; Witczak-Legrand, A.; Gonzalez, P.; Bontemps-Subielos, N.; Banaigs, B. Structure and total synthesis of cyclodidemnamide B, a cycloheptapeptide from the ascidian Didemnum molle. Tetrahedron Lett. 2002, 43, 4041-4044. [CrossRef]

43. Carroll, A.R.; Bowden, B.F.; Coll, J.C.; Hockless, D.C.R.; Skelton, B.W.; White, A.H. Studies of Australian ascidians. IV. Mollamide, a cytotoxic cyclic heptapeptide from the compound ascidian Didemnum molle. Aust. J. Chem. 1994, 47, 61-69. [CrossRef]

44. Carroll, A.R.; Coll, J.C.; Bourne, J.C.; MacLeod, J.K.; Zanriskie, T.M.; Ireland, C.M.; Bowden, B.F. Patellins 1-6 and trunkamide A: Novel cyclic hexa-, hepta- and octa-peptides from colonial ascidians, Lissoclinum sp. Aust. J. Chem. 1996, 49, 659-667. [CrossRef]

45. Rudi, A.; Aknin, M.; Gaydou, E.M.; Kashman, Y. Four new cytotoxic cyclic hexa- and heptapeptides from the marine ascidian Didemnum molle. Tetrahedron 1998, 54, 13203-13210. [CrossRef]

46. Donia, M.S.; Wang, B.; Dunbar, D.C.; Desai, P.V.; Patny, A.; Avery, M.; Hamann, M.T. Mollamides B and C, cyclic hexapeptides from the Indonesian tunicate Didemnum molle. J. Nat. Prod. 2008, 71, 941-945. [CrossRef]

47. Lu, Z.; Harper, M.K.; Pond, C.D.; Barrows, L.R.; Ireland, C.M.; Van Wagoner, R.M. Thiazoline peptides and a tris-phenethyl urea from Didemnum molle with anti-HIV activity. J. Nat. Prod. 2012, 75, 1436-1440. [CrossRef]

48. Rudi, A.; Chill, L.; Aknin, M.; Kashman, Y. Didmolamide A and B, two new cyclic hexapeptides from the marine ascidian Didemnum molle. J. Nat. Prod. 2003, 66, 575-577. [CrossRef]

49. Teruya, T.; Sasaki, H.; Suenaga, K. Hexamollamide, a hexapeptide from an Okinawan ascidian Didemnum molle. Tetrahedron Lett. 2008, 49, 5297-5299. [CrossRef]

50. Perez, L.J.; Faulkner, D.J. Bistratamides E-J, modified cyclic hexapeptides from the Philippines ascidian Lissoclinum bistratum. J. Nat. Prod. 2003, 66, 247-250. [CrossRef]

51. Fu, X.; Do, T.; Schmitz, F.J.; Andrusevich, V.; Engel, M.H. New cyclic peptides from the ascidian Lissoclinum patella. J. Nat. Prod. 1998, 61, 1547-1551. [CrossRef] [PubMed] 
52. Morris, L.A.; Jantina Kettenes van den Bosch, J.; Versluis, K.; Thompson, G.S.; Jaspars, M. Structure determination and $\mathrm{MS}^{\mathrm{n}}$ analysis of two new lissoclinamides isolated from the Indo-Pacific ascidian Lissoclinum patella: NOE restrained molecular dynamics confirms the absolute stereochemistry derived by degradative methods. Tetrahedron 2000, 56, 8345-8353. [CrossRef]

53. Ireland, C.; Scheuer, P.J. Ulicyclamide and ulithiacyclamide, two new small peptides from a marine tunicate. J. Am. Chem. Soc. 1980, 102, 5688-5691. [CrossRef]

54. Rashid, M.A.; Gustafson, K.R.; Cardellina II, J.H.; Boyd, M.R. Patellamide F, a new cytotoxic cyclic peptide from the colonial ascidian Lissoclinum patella. J. Nat. Prod. 1995, 58, 594-597. [CrossRef] [PubMed]

55. Hawkins, C.J.; Lavin, M.F.; Marshall, K.A.; Van den Brenk, A.L.; Watters, D.J. Structure-activity relationships of the lissoclinamides: Cytotoxic cyclic peptides from the ascidian Lissoclinum patella. J. Med. Chem. 1990, 33, 1634-1638. [CrossRef] [PubMed]

56. Degnan, B.M.; Hawkins, C.J.; Lavin, M.F.; McCaffrey, E.J.; Parry, D.L.; Van den Brenk, A.L.; Watters, D.J. New cyclic peptides with cytotoxic activity from the ascidian Lissoclinum patella. J. Med. Chem. 1989, 32, 1349-1354. [CrossRef] [PubMed]

57. Williams, D.E.; Moore, R.E. The structure of ulithiacyclamide B. Antitumor evaluation of cyclic peptides and macrolides from Lissoclinum patella. J. Nat. Prod. 1989, 52, 732-739. [CrossRef]

58. McDonald, L.A.; Ireland, C.M. Patellamide E: A new cyclic peptide from the ascidian Lissoclinum patella. J. Nat. Prod. 1992, 55, 376-379. [CrossRef]

59. Foster, M.P.; Concepcion, G.P.; Caraan, G.B.; Ireland, C.M. Bistratamides C and D. two new oxazole-containing cyclic hexapeptides isolated from a Philippine Lissoclinum bistratum ascidian. J. Org. Chem. 1992, 57, 6671-6675. [CrossRef]

60. Degnan, B.M.; Hawkins, C.J.; Lavin, M.F.; McCaffrey, E.J.; Parry, D.L.; Watters, D.J. Novel cytotoxic compounds from the ascidian Lissoclinum bistratum. J. Med. Chem. 1989, 32, 1354-1359. [CrossRef]

61. Urda, C.; Fernández, R.; Rodríguez, J.; Pérez, M.; Jiménez, C.; Cuevas, C. Bistratamides M and N, oxazole-thiazole containing cyclic hexapeptides isolated from Lissoclinum bistratum interaction of zinc (II) with bistratamide K. Mar. Drugs 2017, 15, 209. [CrossRef] [PubMed]

62. Toske, S.G.; Fenical, W. Cyclodidemnamide: A new cyclic heptapeptide from the marine ascidian Didemnum molle. Tetrahedron Lett. 1995, 36, 8355-8358. [CrossRef]

63. Rashid, M.A.; Gustafson, K.R.; Boswell, J.L.; Boyd, M.R. Haligramides A and B, two new cytotoxic hexapeptides from the marine sponge Haliclona nigra. J. Nat. Prod. 2000, 63, 956-959. [CrossRef] [PubMed]

64. Schmidt, E.W.; Raventos-Suarez, C.; Bifano, M.; Menendez, A.T.; Fairchild, C.R.; Faulkner, D.J. Scleritodermin A, a cytotoxic cyclic peptide from the Lithistid sponge Scleritoderma nodosum. J. Nat. Prod. 2004, 67, 475-478. [CrossRef]

65. Chill, L.; Kashman, Y.; Schleyer, M. Oriamide, a new cytotoxic cyclic peptide containing a novel amino acid from the marine sponge Theonella sp. Tetrahedron 1997, 53, 16147-16152. [CrossRef]

66. Mau, C.M.S.; Nakao, Y.; Yoshida, W.Y.; Scheuer, P.J. Waiakeamide, a cyclic hexapeptide from the sponge Ircinia dendroides. J. Org. Chem. 1996, 61, 6302-6304. [CrossRef]

67. Kobayashi, J.; Itagaki, F.; Shigemori, I.; Takao, T.; Shimonishi, Y. Keramamides E, G, H, and J, new cyclic peptides containing an oxazole or a thiazole ring from a Theonella sponge. Tetrahedron 1995, 51, 2525-2532. [CrossRef]

68. Issac, M.; Aknin, M.; Gauvin-Bialecki, A.; De Voogd, N.; Ledoux, A.; Frederich, M.; Kashman, Y.; Carmeli, S. Cyclotheonellazoles A-C, potent protease inhibitors from the marine sponge Theonella aff. swinhoei. J. Nat. Prod. 2017, 80, 1110-1116. [CrossRef]

69. Erickson, K.L.; Gustafson, K.R.; Milanowski, D.J.; Pannell, L.K.; Klose, J.R.; Boyd, M.R. Myriastramides A-C, new modified cyclic peptides from the Philippines marine sponge Myriastra clavosa. Tetrahedron 2003, 59, 10231-10238. [CrossRef]

70. Kehraus, S.; König, G.M.; Wright, A.D.; Woerheide, G. Leucamide A: A new cytotoxic heptapeptide from the Australian sponge Leucetta microraphis. J. Org. Chem. 2002, 67, 4989-4992. [CrossRef]

71. Tan, K.O.; Wakimoto, T.; Takada, K.; Ohtsuki, T.; Uchiyama, N.; Goda, Y.; Abe, I. Cycloforskamide, a cytotoxic macrocyclic peptide from the sea slug Pleurobranchus forskalii. J. Nat. Prod. 2013, 76, 1388-1391. [CrossRef] [PubMed]

72. Wesson, K.J.; Hamann, M.T. Keenamide A, a bioactive cyclic peptide from the marine mollusk Pleurobranchus forskalii. J. Nat. Prod. 1996, 59, 629-631. [CrossRef] [PubMed] 
73. Dalisay, D.S.; Rogers, E.W.; Edison, A.S.; Molinski, T.F. Structure elucidation at the nanomole scale. 1. Trisoxazole macrolides and thiazole-containing cyclic peptides from the nudibranch Hexabranchus sanguineus. J. Nat. Prod. 2009, 72, 732-738. [CrossRef] [PubMed]

74. Zhou, X.; Huang, H.; Chen, Y.; Tan, J.; Song, Y.; Zou, J.; Tian, X.; Hua, Y.; Ju, J. Marthiapeptide A, an anti-infective and cytotoxic polythiazole cyclopeptide from a $60 \mathrm{~L}$ scale fermentation of the deep sea-derived Marinactinospora thermotolerans SCSIO 00652. J. Nat. Prod. 2012, 75, 2251-2255. [CrossRef]

75. Sone, H.; Kigoshi, H.; Yamada, K. Isolation and stereostructure of dolastatin I, a cytotoxic cyclic hexapeptide from the Japanese sea hare Dolabella auricularia. Tetrahedron 1997, 53, 8149-8154. [CrossRef]

76. Ojika, M.; Nemoto, T.; Nakamura, M.; Yamada, K. Dolastatin E, a new cyclic hexapeptide isolated from the sea hare Dolabella auricularia. Tetrahedron Lett. 1995, 36, 5057-5058. [CrossRef]

77. Tan, L.T.; Williamson, R.T.; Gerwick, W.H.; Watts, K.S.; McGough, K.; Jacobs, R. cis, cis- and trans, trans-Ceratospongamide, new bioactive cyclic heptapeptides from the Indonesian red alga Ceratodictyon spongiosum and symbiotic sponge Sigmadocia symbiotica. J. Org. Chem. 2000, 65, 419-425. [CrossRef]

78. Matsuo, Y.; Kanoh, K.; Yamori, T.; Kasai, H.; Katsuta, A.; Adachi, K.; Shin-ya, K.; Shizuri, Y. Urukthapelstatin A, a novel cytotoxic substance from marine-derived Mechercharimyces asporophorigenens YM11-542. J. Antibiot. 2007, 60, 251-255. [CrossRef]

79. Kanoh, K.; Matsuo, Y.; Adachi, K.; Imagawa, H.; Nishizawa, M.; Shizuri, Y. Mechercharmycins A and B, cytotoxic substances from marine-derived Thermoactinomyces sp. YM3-251. J. Antibiot. 2005, 58, $289-292$. [CrossRef]

80. Itokawa, H.; Yun, Y.; Morita, H.; Takeya, K.; Yamada, K. Estrogen-like activity of cyclic peptides from Vaccaria segetalis extracts. Planta Med. 1995, 61, 561-562. [CrossRef]

81. Joo, S.H. Cyclic Peptides as therapeutic agents and biochemical tools. Biomol. Ther. (Seoul) 2012, 20, 19-26. [CrossRef] [PubMed]

82. Goodwin, D.; Simerska, P.; Toth, I. Peptides as therapeutics with enhanced bioactivity. Curr. Med. Chem. 2012, 19, 4451-4461. [CrossRef]

83. Pathak, D.; Dahiya, R. Cyclic peptides as novel antineoplastic agents: A review. J. Sci. Pharm. 2003, 4, 125-131.

84. Clark, W.D.; Corbett, T.; Valeriote, F.; Crews, P. Cyclocinamide A. An unusual cytotoxic halogenated hexapeptide from the marine sponge Psammocinia. J. Am. Chem. Soc. 1997, 119, 9285-9286. [CrossRef]

85. Laird, D.W.; LaBarbera, D.V.; Feng, X.; Bugni, T.S.; Harper, M.K.; Ireland, C.M. Halogenated cyclic peptides isolated from the sponge Corticium sp. J. Nat. Prod. 2007, 70, 741-746. [CrossRef] [PubMed]

86. Luesch, H.; Yoshida, W.Y.; Moore, R.E.; Paul, V.J. Isolation and structure of the cytotoxin Lyngbyabellin $\mathrm{B}$ and absolute configuration of Lyngbyapeptin A from the marine cyanobacterium Lyngbya majuscula. J. Nat. Prod. 2000, 63, 1437-1439. [CrossRef]

87. Kobayashi, L.; Sato, M.; Murayama, T.; Ishibashi, M.; Walchi, M.R.; Kanai, M.; Shoji, J.; Ohizumie, Y. Konbamide, a novel peptide with calmodulin antagonistic activity from the okinawan marine sponge Theonella sp. J. Chem. Soc. Chem. Commun. 1991, 1050-1052. [CrossRef]

88. Gulavita, N.K.; Gunasekela, S.P.; Pomponi, S.A.; Robinson, E.V. Polydiscamide A: A new bioactive depsipeptide from the marine sponge Discodermia sp. J. Org. Chem. 1992, 57, 1767-1772. [CrossRef]

89. Jamison, M.T.; Molinski, T.F. Jamaicensamide A, a peptide containing $\beta$-amino- $\alpha$-keto and thiazole-homologated $\eta$-amino acid residues from the sponge Plakina jamaicensis. J. Nat. Prod. 2016, 79, 2243-2249. [CrossRef]

90. Pettit, G.R.; Kamano, Y.; Holzapfel, C.W.; van Zyl, W.J.; Tuinman, A.A.; Herald, C.L.; Baczynskyj, L.; Schmidt, J.M. Antineoplastic agents. 150. The structure and synthesis of dolastatin 3. J. Am. Chem. Soc. 1987, 109, 7581-7582. [CrossRef]

91. Raveh, A.; Carmeli, S. Aeruginazole A, a novel thiazole-containing cyclopeptide from the cyanobacterium Microcystis sp. Org. Lett. 2010, 12, 3536-3539. [CrossRef] [PubMed]

92. Williams, P.G.; Yoshida, W.Y.; Moore, R.E.; Paul, V.J. Micromide and guamamide: Cytotoxic alkaloids from a species of the marine cyanobacterium Symploca. J. Nat. Prod. 2004, 67, 49-53. [CrossRef]

93. Poncet, J. The dolastatins, a family of promising antineoplastic agents. Curr. Pharm. Des. 1999, 5, 139-162. [PubMed] 
94. Luesch, H.; Moore, R.E.; Paul, V.J.; Mooberry, S.L.; Corbett, T.H. Isolation of dolastatin 10 from the marine cyanobacterium Symploca species VP642 and total stereochemistry and biological evaluation of its analogue symplostatin 1. J. Nat. Prod. 2001, 64, 907-910. [CrossRef] [PubMed]

95. Harrigan, G.G.; Luesch, H.; Yoshida, W.Y.; Moore, R.E.; Nagle, D.G.; Paul, V.J.; Mooberry, S.L.; Corbett, T.H.; Valeriote, F.A. Symplostatin 1: A dolastatin 10 analogue from the marine cyanobacterium Symploca hydnoides. J. Nat. Prod. 1998, 61, 1075-1077. [CrossRef] [PubMed]

96. Pettit, G.R.; Xu, J.; Williams, M.D.; Hogan, F.; Schmidt, J.M.; Cerny, R.L. Antineoplastic agents 370. Isolation and structure of dolastatin 18. Bioorg. Med. Cem. Lett. 1997, 7, 827-832. [CrossRef]

97. Klein, D.; Braekman, J.-C.; Daloze, D.; Hoffmann, L.; Castillo, G.; Demoulin, V. Lyngbyapeptin A, a modified tetrapeptide from Lyngbya bouillonii (Cyanophyceae). Tetrahedron Lett. 1999, 40, 695-696. [CrossRef]

98. Luesch, H.; Yoshida, W.Y.; Moore, R.E.; Paul, V.J. Structurally diverse new alkaloids from Palauan collections of the apratoxin-producing marine cyanobacterium Lyngbya sp. Tetrahedron 2002, 58, 7959-7966. [CrossRef]

99. Tan, L.T. Marine Cyanobacteria: A Treasure Trove of Bioactive Secondary Metabolites for Drug Discovery. In Studies in Natural Product Chemistry, 1st ed.; Atta-ur-Rahman, Ed.; Elsevier: Amsterdam, The Netherlands, 2012; Volume 36, p. 80, Chapter 4.

100. Luesch, H.; Yoshida, W.Y.; Moore, R.E.; Paul, V.J. Apramides A-G, novel lipopeptides from the marine cyanobacterium Lyngbya majuscula. J. Nat. Prod. 2000, 63, 1106-1112. [CrossRef]

101. Sorek, H. Isolation, structure elucidation and biological activity of natural products from marine organisms. Ph.D. Thesis, Tel Aviv University, Tel Aviv, Israel, 2010.

102. Boden, C.; Pattenden, G. Total synthesis of lissoclinamide 5, a cytotoxic cyclic peptide from the tunicate Lissoclinum patella. Tetrahedron Lett. 1994, 35, 8271-8274. [CrossRef]

103. Wipf, P.; Fritch, P.C. Total synthesis and assignment of configuration of lissoclinamide 7. J. Am. Chem. Soc. 1996, 118, 12358-12367. [CrossRef]

104. Boden, C.D.J.; Pattenden, G. Total syntheses and re-assignment of configurations of the cyclopeptides lissoclinamide 4 and lissoclinamide 5 from Lissoclinum patella. J. Chem. Soc. Perkin Trans. 1 2000, 6, 875-882. [CrossRef]

105. Banker, R.; Carmeli, S. Tenuecyclamides A-D, cyclic hexapeptides from the cyanobacterium Nostoc spongiaeforme var. tenue. J. Nat. Prod. 1998, 61, 1248-1251. [CrossRef] [PubMed]

106. Hamamoto, Y.; Endo, M.; Nakagawa, M.; Nakanishi, T.; Mizukawa, K. A new cyclic peptide, ascidiacyclamide, isolated from ascidian. J. Chem. Soc. Chem. Commun. 1983, 6, 323-324. [CrossRef]

107. Todorova, A.K.; Juettner, F.; Linden, A.; Pluess, T.; von Philipsborn, W. Nostocyclamide: A new macrocyclic, thiazole-containing allelochemical from Nostoc sp. 31 (cyanobacteria). J. Org. Chem. 1995, 60, 7891-7895. [CrossRef]

108. Sera, Y.; Adachi, K.; Fujii, K.; Shizuri, Y. A new antifouling hexapeptide from a palauan sponge, Haliclona sp. J. Nat. Prod. 2003, 66, 719-721. [CrossRef]

109. Uemoto, H.; Yahiro, Y.; Shigemori, H.; Tsuda, M.; Takao, T.; Shimonishi, Y.; Kobayashi, J. Keramamides K and L, new cyclic peptides containing unusual tryptophan residue from Theonella sponge. Tetrahedron 1998, 54, 6719-6724. [CrossRef]

110. Kimura, M.; Wakimoto, T.; Egami, Y.; Tan, K.C.; Ise, Y.; Abe, I. Calyxamides A and B, cytotoxic cyclic peptides from the marine sponge Discodermia calyx. J. Nat. Prod. 2012, 75, 290-294. [CrossRef]

111. Just-Baringo, X.; Albericio, F.; Alvarez, M. Thiopeptide antibiotics: Retrospective and recent advances. Mar. Drugs 2014, 12, 317-351. [CrossRef]

112. Engelhardt, K.; Degnes, K.F.; Kemmler, M.; Bredholt, H.; Fjaervik, E.; Klinkenberg, G.; Sletta, H.; Ellingsen, T.E.; Zotchev, S.B. Production of a new thiopeptide antibiotic, TP-1161, by a marine Nocardiopsis species. Appl. Environ. Microbiol. 2010, 76, 4969-4976. [CrossRef]

113. Suzumura, K.; Yokoi, T.; Funatsu, M.; Nagai, K.; Tanaka, K.; Zhang, H.; Suzuki, K. YM-266183 and YM-266184, novel thiopeptide antibiotics produced by Bacillus cereus isolated from a marine sponge II. Structure elucidation. J. Antibiot (Tokyo) 2003, 56, 129-134. [CrossRef] [PubMed]

114. Palomo, S.; González, I.; de la Cruz, M.; Martín, J.; Tormo, J.R.; Anderson, M.; Hill, R.T.; Vicente, F.; Reyes, F.; Genilloud, O. Sponge-derived Kocuria and Micrococcus spp. as sources of the new thiazolyl peptide antibiotic kocurin. Mar. Drugs 2013, 11, 1071-1086. [CrossRef] [PubMed] 
115. Just-Baringo, X.; Bruno, P.; Ottesen, L.K.; Cañedo, L.M.; Albericio, F.; Álvarez, M. Total synthesis and stereochemical assignment of baringolin. Angew. Chem. Int. Ed. Engl. 2013, 52, 7818-7821. [CrossRef] [PubMed]

116. Iniyan, A.M.; Sudarman, E.; Wink, J.; Kannan, R.R.; Vincent, S.G.P. Ala-geninthiocin, a new broad spectrum thiopeptide antibiotic, produced by a marine Streptomyces sp. ICN19. J. Antibiot. 2019, 72, 99-105. [CrossRef] [PubMed]

117. Ireland, C.M.; Durso, A.R.; Newman, R.A.; Hacker, M.P. Antineoplastic cyclic peptides from the marine tunicate Lissoclinum patella. J. Org. Chem. 1982, 47, 1807-1811. [CrossRef]

118. Bewley, C.A.; He, H.; Williams, D.H.; Faulkner, D.J. Aciculitins A-C: Cytotoxic and antifungal cyclic peptides from the lithistid sponge Aciculites orientalis. J. Am. Chem. Soc. 1996, 118, 4314-4321. [CrossRef]

119. Bewley, C.A.; Faulkner, D.J. Theonegramide, an antifungal glycopeptide from the Philippine lithistid sponge Theonella swinhoei. J. Org. Chem. 1994, 59, 4849-4852. [CrossRef]

120. Matsunaga, S.; Fusetani, N. Theonellamides A-E, cytotoxic bicyclic peptides, from a marine sponge Theonella sp. J. Org. Chem. 1995, 60, 1177-1181. [CrossRef]

121. Matsunaga, S.; Fusetani, N.; Hashimoto, K.; Walchli, M. Theonellamide, F. A novel antifungal bicyclic peptide from a marine sponge Theonella sp. J. Am. Chem. Soc. 1989, 111, 2582-2588. [CrossRef]

122. Morita, H.; Shimbo, K.; Shigemori, H.; Kobayashi, J. Antimitotic activity of moroidin, a bicyclic peptide from the seeds of Celosia argentea. Bioorg. Med. Chem. Lett. 2000, 10, 469-471. [CrossRef]

123. Kobayashi, J.; Suzuki, H.; Shimbo, K.; Takeya, K.; Morita, H. Celogentins A-C, new antimitotic bicyclic peptides from the seeds of Celosia argentea. J. Org. Chem. 2001, 66, 6626-6633. [CrossRef] [PubMed]

124. Rhodes, C.A.; Pei, D. Bicyclic Peptides as next-generation therapeutics. Chemistry 2017, 23, 12690-12703. [CrossRef] [PubMed]

125. Zhao, J.-C.; Yu, S.-M.; Liu, Y.; Yao, Z.-J. Biomimetic synthesis of ent-(-)-Azonazine and stereochemical reassignment of natural product. Org. Lett. 2013, 15, 4300-4303. [CrossRef] [PubMed]

126. Sun, P.; Maloney, K.N.; Nam, S.-J.; Haste, N.M.; Raju, R.; Aalbersberg, W.; Jensen, P.R.; Nizet, V.; Hensler, M.E.; Fenical, W. Fijimycins A-C, three antibacterial etamycin-class depsipeptides from a marine-derived Streptomyces sp. Bioorg. Med. Chem. 2011, 19, 6557-6562. [CrossRef]

127. Gala, F.; D'Auria, M.V.; De Marino, S.; Sepe, V.; Zollo, F.; Smith, C.D.; Keller, S.N.; Zampella, A. Jaspamides M-P: New tryptophan modified jaspamide derivatives from the sponge Jaspis splendans. Tetrahedron 2009, 65, 51-56. [CrossRef]

128. Tabudravu, J.; Morris, L.A.; Kettenes-van den Bosch, J.J.; Jaspars, M. Wainunuamide, a histidine-containing proline-rich cyclic heptapeptide isolated from the Fijian marine sponge Stylotella aurantium. Tetrahedron Lett. 2001, 42, 9273-9276. [CrossRef]

129. Um, S.; Kim, Y.-J.; Kwon, H.; Wen, H.; Kim, S.-H.; Kwon, H.C.; Park, S.; Shin, J.; Oh, D.-C. Sungsanpin, a lasso peptide from a deep-sea Streptomycete. J. Nat. Prod. 2013, 76, 873-879. [CrossRef]

130. Song, Y.; Li, Q.; Liu, X.; Chen, Y.; Zhang, Y.; Sun, A.; Zhang, W.; Zhang, J.; Ju, J. Cyclic hexapeptides from the deep South China sea-derived Streptomyces scopuliridis SCSIO ZJ46 active against pathogenic gram-positive bacteria. J. Nat. Prod. 2014, 77, 1937-1941. [CrossRef]

131. Zheng, J.; Zhu, H.; Hong, K.; Wang, Y.; Liu, P.; Wang, X.; Peng, X.; Zhu, W. Novel cyclic hexapeptides from marine-derived fungus, Aspergillus sclerotiorum PT06-1. Org. Lett. 2009, 11, 5262-5265. [CrossRef]

132. Mueller, L.K.; Baumruck, A.C.; Zhdanova, H.; Tietze, A.A. Challenges and perspectives in chemical synthesis of highly hydrophobic peptides. Front. Bioeng. Biotechnol. 2020, 8, 162. [CrossRef]

133. Dahiya, R.; Pathak, D. First total synthesis and biological evaluation of halolitoralin A. J. Serb. Chem. Soc. 2007, 72, 101-107. [CrossRef]

134. Dahiya, R.; Pathak, D. Synthesis, characterization and biological evaluation of halolitoralin B-A natural cyclic peptide. Asian J. Chem. 2007, 19, 1499-1505.

135. Dahiya, R.; Pathak, D. Synthetic studies on a natural cyclic tetrapeptide-halolitoralin C. J. Pharm. Res. 2006, 5, 69-73.

136. Dahiya, R.; Pathak, D.; Bhatt, S. Synthesis and biological evaluation of a novel series of 2-(2'-isopropyl-5'-methylphenoxy) acetyl amino acids and dipeptides. Bull. Chem. Soc. Ethiop. 2006, 20, 235-245. [CrossRef]

137. Dahiya, R.; Pathak, D. Synthetic studies on novel benzimidazolopeptides with antimicrobial, cytotoxic and anthelmintic potential. Eur. J. Med. Chem. 2007, 42, 772-798. [CrossRef] 
138. Dahiya, R.; Kumar, A.; Yadav, R. Synthesis and biological activity of peptide derivatives of iodoquinazolinones/nitroimidazoles. Molecules 2008, 13, 958-976. [CrossRef]

139. Dahiya, R. Synthesis, characterization and antimicrobial studies on some newer imidazole analogs. Sci. Pharm. 2008, 76, 217-240. [CrossRef]

140. Rajiv, M.H.; Ramana, M.V. Synthesis of 6-nitrobenzimidazol-1-acetyl amino acids and peptides as potent anthelmintic agents. Indian J. Heterocycl. Chem. 2002, 12, 121-124.

141. Dahiya, R.; Mourya, R.; Agrawal, S.C. Synthesis and antimicrobial screening of peptidyl derivatives of bromocoumarins/methylimidazoles. Afr. J. Pharma. Pharmacol. 2010, 4, $214-225$.

142. Dahiya, R.; Kumar, A. Synthesis, spectral and anthelmintic activity studies on some novel imidazole derivatives. E-J. Chem. 2008, 5, 1133-1143. [CrossRef]

143. Himaja, M.; Rajiv; Ramana, M.V.; Poojary, B.; Satyanarayana, D.; Subrahmanyam, E.V.; Bhat, K.I. Synthesis and biological activity of a novel series of $4-[2$ '-(6'-nitro) benzimidazolyl] benzoyl amino acids and peptides. Boll. Chim. Farmac. 2003, 142, 450-453.

144. Dahiya, R.; Kaur, R. Synthesis and anthelmintic potential of a novel series of 2-mercaptobenzimidazolopeptides. Biosci. Biotech. Res. Asia 2007, 4, 561-566.

145. Singh, A.P.; Ramadan, W.M.; Dahiya, R.; Sarpal, A.S.; Pathak, K. Product development studies of amino acid conjugate of aceclofenac. Curr. Drug Deliv. 2009, 6, 208-216. [CrossRef] [PubMed]

146. Dahiya, R.; Mourya, R. Synthesis of peptide analogs of 4-[2-(3-bromophenyl)-7-nitro-4-oxo-3, 4-dihydro-3-quinazolinyl] benzoic acids as potent antifungal agents. Indian J. Heterocycl. Chem. 2013, 22, 407-412.

147. Dahiya, R.; Pathak, D. Synthesis of heterocyclic analogs of 5-(4-methylcarboxamidophenyl)-2- furoic acid as potent antimicrobial agents. Indian J. Heterocycl. Chem. 2006, 16, 53-56.

148. Dahiya, R.; Mourya, R. Synthetic studies on novel nitroquinazolinone analogs with antimicrobial potential. Bull. Pharm. Res. 2013, 3, 51-57.

149. Dahiya, R.; Kaur, R. Synthesis of some 1, 2, 5-trisubstituted benzimidazole analogs as possible anthelmintic and antimicrobial agents. Int. J. Biol. Chem. Sci. 2008, 2, 1-13. [CrossRef]

150. Dahiya, R.; Bansal, Y. Synthesis and antimicrobial potential of novel quinoxalinopeptide analogs. Res. J. Chem. Environ. 2008, 12, 52-58.

151. Dahiya, R. Synthesis of 4-(2-methyl-1H-5-imidazolyl) benzoyl amino acids and peptides as possible anthelmintic agents. Ethiop. Pharm. J. 2008, 26, 17-26. [CrossRef]

152. Dahiya, R.; Kumar, S.; Khokra, S.L.; Gupta, S.V.; Sutariya, V.B.; Bhatia, D.; Sharma, A.; Singh, S.; Maharaj, S. Toward the synthesis and improved biopotential of an $\mathrm{N}$-methylated analog of a proline-rich cyclic tetrapeptide from marine bacteria. Mar. Drugs 2018, 16, 305. [CrossRef]

153. Dahiya, R.; Singh, S. Synthesis, characterization, and biological activity studies on fanlizhicyclopeptide A. Iran. J. Pharm. Res. 2017, 16, 1176-1184. [PubMed]

154. Dahiya, R.; Singh, S.; Sharma, A.; Chennupati, S.V.; Maharaj, S. First total synthesis and biological screening of a proline-rich cyclopeptide from a Caribbean marine sponge. Mar. Drugs 2016, 14, 228. [CrossRef] [PubMed]

155. Dahiya, R.; Gautam, H. Total synthesis and antimicrobial activity of a natural cycloheptapeptide of marine origin. Mar. Drugs 2010, 8, 2384-2394. [CrossRef] [PubMed]

156. Dahiya, R.; Kumar, A.; Gupta, R. Synthesis, cytotoxic and antimicrobial screening of a proline-rich cyclopolypeptide. Chem. Pharm. Bull. (Tokyo) 2009, 57, 214-217. [CrossRef]

157. Dahiya, R. Total synthesis and biological potential of psammosilenin A. Arch. Pharm. (Weinheim) 2008, 341, 502-509. [CrossRef]

158. Dahiya, R. Synthesis of a phenylalanine-rich peptide as potential anthelmintic and cytotoxic agent. Acta Pol. Pharm. 2007, 64, 509-516.

159. Dahiya, R. Synthetic and pharmacological studies on longicalycinin A. Pak. J. Pharm. Sci. 2007, 20, 317-323.

160. Dahiya, R.; Pathak, D.; Himaja, M.; Bhatt, S. First total synthesis and biological screening of hymenamide E. Acta Pharm. 2006, 56, 399-415.

161. Dahiya, R.; Gautam, H. Solution phase synthesis and bioevaluation of cordyheptapeptide B. Bull. Pharm. Res. 2011, 1, 1-10.

162. Dahiya, R. Synthesis, characterization and biological evaluation of a glycine-rich peptidecherimolacyclopeptide E. J. Chil. Chem. Soc. 2007, 52, 1224-1229. [CrossRef] 
163. Dahiya, R. Synthesis and in vitro cytotoxic activity of a natural peptide of plant origin. J. Iran. Chem. Soc. 2008, 5, 445-452. [CrossRef]

164. Dahiya, R. Synthesis, spectroscopic and biological investigation of cyclic octapeptide: Cherimolacyclopeptide G. Turk. J. Chem. 2008, 32, 205-215.

165. Dahiya, R.; Maheshwari, M.; Kumar, A. Toward the synthesis and biological evaluation of hirsutide. Monatsh. Chem. 2009, 140, 121-127. [CrossRef]

166. Dahiya, R. Synthesis and biological activity of a cyclic hexapeptide from Dianthus superbus. Chem. Pap. 2008, 62, 527-535. [CrossRef]

167. Dahiya, R.; Gautam, H. Synthesis and pharmacological studies on a cyclooligopeptide from marine bacteria. Chin. J. Chem. 2011, 29, 1911-1916.

168. Dahiya, R.; Singh, S.; Kaur, K.; Kaur, R. Total synthesis of a natural cyclooligopeptide from fruits of sugar-apples. Bull. Pharm. Res. 2017, 7, 151.

169. Dahiya, R.; Singh, S. First total synthesis and biological potential of a heptacyclopeptide of plant origin. Chin. J. Chem. 2016, 34, 1158-1164. [CrossRef]

170. Bruno, P.; Peña, S.; Just-Baringo, X.; Albericio, F.; Álvarez, M. Total synthesis of aeruginazole A. Org. Lett. 2011, 13, 4648-4651. [CrossRef]

171. You, S.-L.; Kelly, J.W. Total synthesis of didmolamides A and B. Tetrahedron Lett. 2005, 46, 2567-2570. [CrossRef]

172. Zhou, W.; Nie, X.-D.; Zhang, Y.; Si, C.-M.; Zhou, Z.; Sun, X.; Wei, B.-G. A practical approach to asymmetric synthesis of dolastatin 10. Org. Biomol. Chem. 2017, 15, 6119-6131. [CrossRef]

173. Sellanes, D.; Manta, E.; Serra, G. Toward the total synthesis of scleritodermin A: Preparation of the $\mathrm{C}_{1}-\mathrm{N}_{15}$ fragment. Tetrahedron Lett. 2007, 48, 1827-1830. [CrossRef] [PubMed]

174. Zhang, W.; Ma, Z.-H.; Mei, D.; Li, C.-X.; Zhang, X.-L.; Li, Y.-X. Total synthesis and reassignment of stereochemistry of obyanamide. Tetrahedron 2006, 62, 9966-9972. [CrossRef]

175. Zhang, W.; Ding, N.; Li, Y. Synthesis and biological evaluation of analogues of the marine cyclic depsipeptide obyanamide. J. Pept. Sci. 2011, 17, 533-539. [CrossRef] [PubMed]

176. Zhang, Y.; Islam, M.A.; McAlpine, S.R. Synthesis of the natural product marthiapeptide A. Org. Lett. 2015, 17, 5149-5151. [CrossRef] [PubMed]

177. Dahiya, R.; Singh, S.; Varghese Gupta, S.; Sutariya, V.B.; Bhatia, D.; Mourya, R.; Chennupati, S.V.; Sharma, A. First total synthesis and pharmacological potential of a plant based hexacyclopeptide. Iran. J. Pharm. Res. 2019, 18, 938-947.

178. Dahiya, R.; Singh, S. Synthesis, characterization and biological screening of diandrine A. Acta Pol. Pharm. 2017, 74, 873-880.

179. Dahiya, R.; Kumar, A. Synthetic and biological studies on a cyclopolypeptide of plant origin. J. Zhejiang Univ. Sci. B 2008, 9, 391-400. [CrossRef]

180. Dahiya, R.; Kaur, K. Synthesis and pharmacological investigation of segetalin $C$ as a novel antifungal and cytotoxic agent. Arzneimittelforschung 2008, 58, 29-34. [CrossRef]

181. Dahiya, R.; Kaur, K. Synthetic and biological studies on natural cyclic heptapeptide: Segetalin E. Arch. Pharm. Res. 2007, 30, 1380-1386. [CrossRef]

182. Dahiya, R.; Maheshwari, M.; Yadav, R. Synthetic and cytotoxic and antimicrobial activity studies on annomuricatin B. Z. Naturforsch. B 2009, 64, 237-244. [CrossRef]

183. Dahiya, R.; Gautam, H. Toward the first total synthesis of gypsin D: A natural cyclopolypeptide from Gypsophila arabica. Am. J. Sci. Res. 2010, 11, 150-158.

184. Wipf, P.; Fritch, P.C.; Geib, S.J.; Sefler, A.M. Conformational studies and structure-activity analysis of lissoclinamide 7 and related cyclopeptide alkaloids. J. Am. Chem. Soc. 1998, 120, 4105-4112. [CrossRef]

185. Fennell, B.J.; Carolan, S.; Pettit, G.R.; Bell, A. Effects of the antimitotic natural product dolastatin 10, and related peptides, on the human malarial parasite Plasmodium falciparum. J. Antimicrb. Chemother. 2003, 51, 833-841. [CrossRef] [PubMed]

186. Mooberry, S.L.; Leal, R.M.; Tinley, T.L.; Luesch, H.; Moore, R.E.; Corbett, T.H. The molecular pharmacology of symplostatin 1: A new antimitotic dolastatin 10 analog. Int. J. Cancer 2003, 104, 512-521. [CrossRef] [PubMed] 
187. Liu, Y.; Salvador, L.A.; Byeon, S.; Ying, Y.; Kwan, J.C.; Law, B.K.; Hong, J.; Luesch, H. Anticolon cancer activity of largazole, a marine-derived tunable histone deacetylase inhibitor. J. Pharmacol. Exp. Ther. 2010, 335, 351-361. [CrossRef]

188. Kang, H.K.; Choi, M.C.; Seo, C.H.; Park, Y. Therapeutic properties and biological benefits of marine-derived anticancer peptides. Int. J. Mol. Sci. 2018, 19, 919. [CrossRef]

189. Espiritu, R.A.; Cornelio, K.; Kinoshita, M.; Matsumori, N.; Murata, M.; Nishimura, S.; Kakeya, H.; Yoshida, M.; Matsunaga, S. Marine sponge cyclic peptide theonellamide A disrupts lipid bilayer integrity without forming distinct membrane pores. Biochim. Biophys. Acta 2016, 1858, 1373-1379. [CrossRef]

190. Mahaffy, R.E.; Pollard, T.D. Influence of phalloidin on the formation of actin filament branches by Arp $2 / 3$ Complex. Biochemistry 2008, 47, 6460-6467. [CrossRef]

191. Odaka, C.; Sanders, M.L.; Crews, P. Jasplakinolide induces apoptosis in various transformed cell lines by a caspase-3-like protease-dependent pathway. Clin. Diagn. Lab. Immun. 2000, 7, 947-952. [CrossRef]

192. Wu, Q.-X.; Crews, M.S.; Draskovic, M.; Sohn, J.; Johnson, T.A.; Tenney, K.; Valeriote, F.A.; Yao, X.-J.; Bjeldanes, L.F.; Crews, P. Azonazine, a novel dipeptide from a Hawaiian marine sediment-derived fungus, Aspergillus insulicola. Org. Lett. 2010, 12, 4458-4461. [CrossRef]

193. Dahiya, S.; Pathak, K. Physicochemical characterization and dissolution enhancement of aceclofenac-hydroxypropyl beta-cyclodextrin binary systems. PDA J. Pharm. Sci. Technol. 2006, 60, 378-388. [PubMed]

194. Dahiya, S.; Pathak, K. Influence of amorphous cyclodextrin derivatives on aceclofenac release from directly compressible tablets. Pharmazie 2007, 62, 278-283. [PubMed]

195. Dahiya, S.; Kaushik, A.; Pathak, K. improved pharmacokinetics of aceclofenac immediate release tablets incorporating its inclusion complex with hydroxypropyl- $\beta$-cyclodextrin. Sci. Pharm. 2015, 83, 501-510. [CrossRef]

196. Dahiya, S. Studies on formulation development of a poorly water-soluble drug through solid dispersion technique. Thai J. Pharm. Sci. 2010, 34, 77-87.

197. Dahiya, S.; Kaushik, A. Effect of water soluble carriers on dissolution enhancement of aceclofenac. Asian J. Pharm. 2010, 4, 34-40. [CrossRef]

198. Dahiya, S.; Tayde, P. Binary and ternary solid systems of carvedilol. Bull. Pharm. Res. 2013, 3, 128-134.

199. Dahiya, R.; Dahiya, S. Ocular delivery of peptides and proteins. In Drug Delivery for the Retina and Posterior Segment Disease; Patel, J.K., Sutariya, V., Kanwar, J.R., Pathak, Y.V., Eds.; Springer: Cham, Switzerland, 2018; pp. 411-437, Chapter 24.

200. Dahiya, S.; Dahiya, R. Recent nanotechnological advancements in delivery of peptide and protein macromolecules. In Nanotechnology in Biology and Medicine: Research Advancements and Future Perspectives, 1st ed.; Rauta, P.R., Mohanta, Y.K., Nayak, D., Eds.; CRC Press, Taylor \& Francis Group: Boca Raton, FL, USA, 2019; pp. 143-157, Chapter 11.

201. Otvos, L., Jr.; Wade, J.D. Current challenges in peptide-based drug discovery. Front Chem. 2014, $2,62$. [CrossRef]

202. Ayoub, M.; Scheidegger, D. Peptide drugs, overcoming the challenges, a growing business. Chim. Oggi. 2006, 24, 46-48.

203. Usmani, S.S.; Bedi, G.; Samuel, J.S.; Singh, S.; Kalra, S.; Kumar, P.; Ahuja, A.A.; Sharma, M.; Gautam, A.; Raghava, G.P.S. THPdb: Database of FDA-approved peptide and protein therapeutics. PLoS ONE 2017, 12, e0181748. [CrossRef]

204. Perez, E.A.; Hillman, D.W.; Fishkin, P.A.; Krook, J.E.; Tan, W.W.; Kuriakose, P.A.; Alberts, S.R.; Dakhil, S.R. Phase II trial of dolastatin-10 in patients with advanced breast cancer. Investig. New Drugs 2005, 23, 257-261. [CrossRef]

205. Mita, A.C.; Hammond, L.A.; Bonate, P.L.; Weiss, G.; McCreery, H.; Syed, S.; Garrison, M.; Chu, Q.S.; DeBono, J.S.; Jones, C.B.; et al. Phase I and pharmacokinetic study of tasidotin hydrochloride (ILX651), a third-generation dolastatin-15 analogue, administered weekly for 3 weeks every 28 days in patients with advanced solid tumors. Clin. Cancer Res. 2006, 12, 5207-5215. [CrossRef] [PubMed]

206. Smyth, J.; Boneterre, M.E.; Schellens, J.; Calvert, H.; Greim, G.; Wanders, J.; Hanauske, A. Activity of the dolastatin analogue, LU103793, in malignant melanoma. Ann. Oncol. 2001, 12, 509-511. [CrossRef] [PubMed] 
207. Riely, G.J.; Gadgeel, S.; Rothman, I.; Saidman, B.; Sabbath, K.; Feit, K.; Kris, M.G.; Rizvi, N.A. A phase 2 study of TZT-1027, administered weekly to patients with advanced non-small cell lung cancer following treatment with platinum-based chemotherapy. Lung Cancer 2007, 55, 181-185. [CrossRef] [PubMed]

208. Ebbinghaus, S.; Hersh, E.; Cunningham, C.C.; O'Day, S.; McDermott, D.; Stephenson, J.; Richards, D.A.; Eckardt, J.; Haider, O.L.; Hammond, L.A. Phase II study of synthadotin (SYN-D.; ILX651) administered daily for 5 consecutive days once every 3 weeks (qdx5q3w) in patients (Pts) with inoperable locally advanced or metastatic melanoma. J. Clin. Oncol. 2004, 22, 7530. [CrossRef]

209. Supko, J.G.; Lynch, T.J.; Clark, J.W.; Fram, R.; Allen, L.F.; Velagapudi, R.; Kufe, D.W.; Eder, J.P., Jr. A phase I clinical and pharmacokinetic study of the dolastatin analogue cemadotin administered as a 5-day continuous intravenous infusion. Cancer Chemother. Pharmacol. 2000, 46, 319-328. [CrossRef] [PubMed]

210. Giddings, L.A.; Newman, D.J. Microbial natural products: Molecular blueprints for antitumor drugs. J. Ind. Microbiol. Biotechnol. 2013, 40,1181-1210. [CrossRef]

211. Newman, D.J.; Cragg, G.M. Current status of marine-derived compounds as warheads in anti-tumor drug candidates. Mar. Drugs 2017, 15, 99. [CrossRef]

(C) 2020 by the authors. Licensee MDPI, Basel, Switzerland. This article is an open access article distributed under the terms and conditions of the Creative Commons Attribution (CC BY) license (http://creativecommons.org/licenses/by/4.0/). 

MDPI

St. Alban-Anlage 66

4052 Basel

Switzerland

Tel. +41616837734

Fax +41 613028918

www.mdpi.com

Marine Drugs Editorial Office

E-mail: marinedrugs@mdpi.com www.mdpi.com/journal/marinedrugs

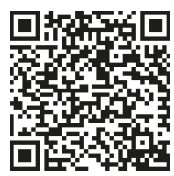





\section{MDPI}

St. Alban-Anlage 66

4052 Basel

Switzerland

Tel: +41 616837734

Fax: +41 613028918 